\title{
Improving Land Use Planning (LUP) by integration of landslide susceptibility: An economic case study in Maichau District, Hoabinh Province, Vietnam
}

\author{
Dissertation \\ to obtain the $\mathrm{Ph}$. D. degree \\ in the International Ph. D. Program for Agricultural Sciences in Göttingen \\ (IPAG) \\ at the Faculty of Agricultural Sciences, \\ Georg-August-Universität Göttingen, Germany \\ presented by \\ Do Van Nha \\ born in Namdinh, Vietnam
}

Göttingen, 2012 
1. Name of supervisor: Prof. Rainer Marggraf

2. Name of co-supervisor: Prof. Heiko Faust

Date of dissertation: 15. November 2012 


\section{ACKNOWLEDGEMENTS}

During my $\mathrm{PhD}$ study at the Department of Agricultural Economics and Rural Development at Georg-August-Universität Göttingen, I received support from many colleagues and friends. First of all, I would like to express here my sincere thanks to them all.

I would like to express my gratitude to Prof. Dr. Rainer Marggraf who supervised me throughout this study. I also express my special thanks to Dr. Jan Barkmann at the Department of Agricultural Economics and Rural Development at Georg-August-Universität Göttingen who was always available to discuss details of the thesis. Their guidance, encouragement and enthusiasm were valuable during the completion of this study. I am very thankful to Prof. Dr. Heiko Faust at the faculty of Geography. His valuation has been helpful in improvement of this thesis.

I am deeply indebted to Dr. Nguyen Quang Hoc, Prof. Nguyen Huu Thanh, Mr. Hoang Xuan Mua, Prof. Do Nguyen Hai, Prof. Nguyen Thi Vong, Prof. Nguyen Xuan Thanh, Prof. Tran Van Chinh, Prof. Nguyen Khac Thoi, Prof. Hoang Thai Dai and others colleagues at Hanoi University of Agriculture. It was very kind to share their experience and provide assistance during this period. I would like to specially thank to Mr. Trinh Quoc Thang, Mr. Luu Tien Binh, at the Ministry of Natural Resources Management and Environment for their support and assistance.

In carrying out field trips for this study, I received assistance and support from a large number of people. I would like to deeply thank Mr. Tran Duc Thang, vice director of natural resources management and environment in Hoabinh Province and Mr. Son, Mr. Hoan, Mr. Pinh, Mr. Thanh, officials of the Department of natural resources management and environment in Maichau District. Particular thanks are also spent to 23 officials of natural resources management and environment in 23 communes and farmers for their assistance in data collection and providing necessary information.

I would like to thank the Vietnamese Government, specifically the Ministry of Education and Training, for giving financial support to my study via Project No.322 - the Vietnamese Overseas Scholarship Program and the German Academic Exchange Service (DAAD) for supporting my study in Germany.

Finally, I would like to express my deepest gratitude to my family: to my wife, two sons and also my parents for giving great support, love and inspiration during my doctoral study. 


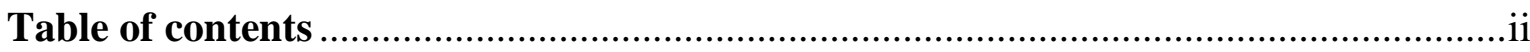

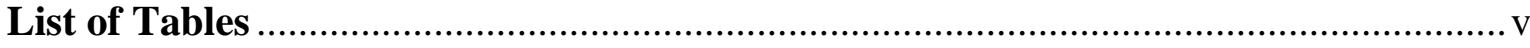

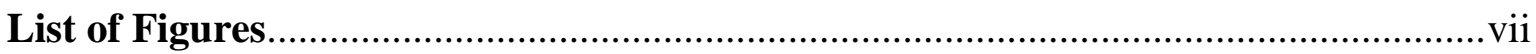

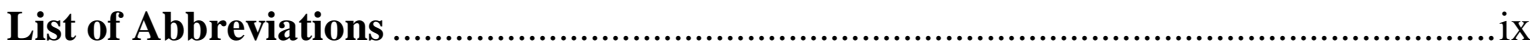

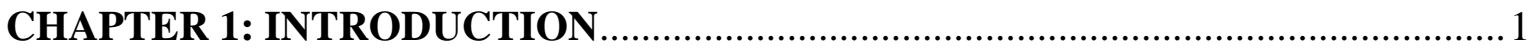

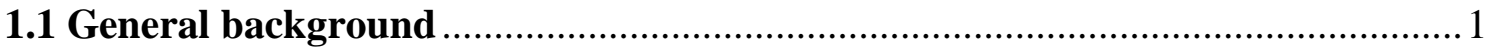

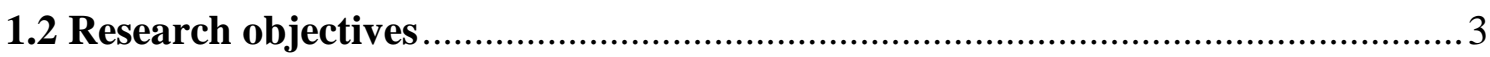

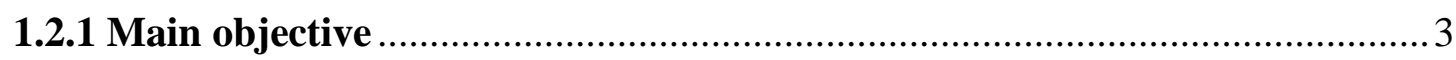

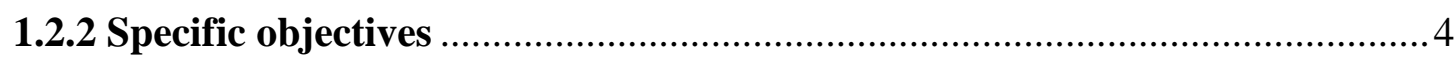

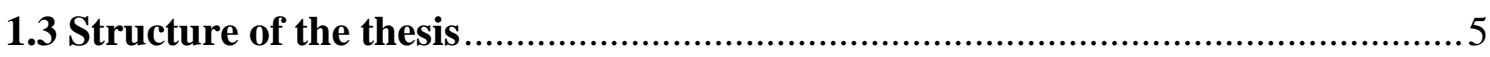

CHAPTER 2: CHARACTERISTICS OF THE RESEARCH AREA ........................ 6

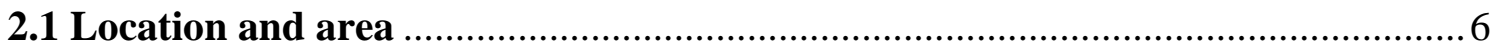

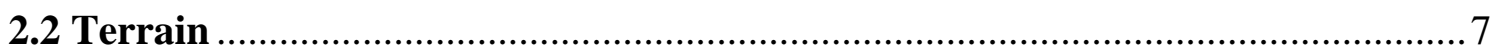

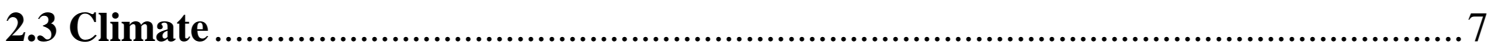

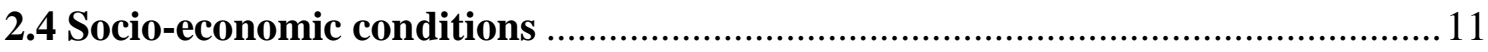

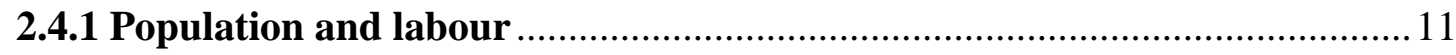

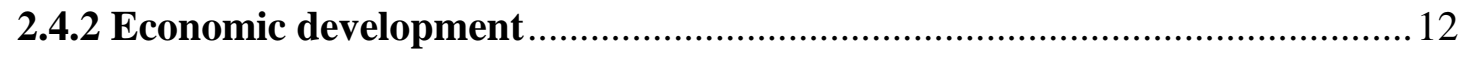

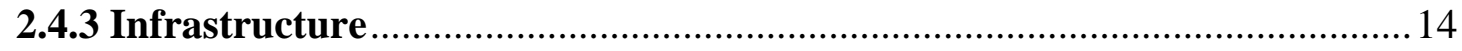

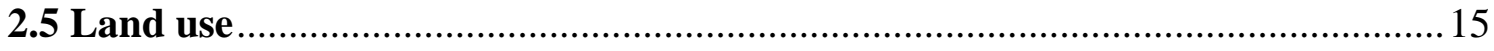

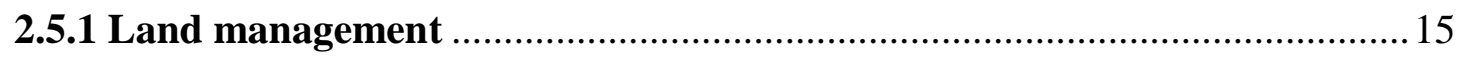

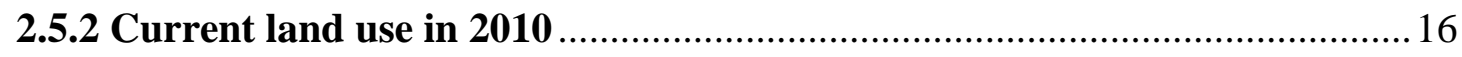

CHAPTER 3: CORRELATION BETWEEN LAND USE PLANNING (LUP) AND SOCIO-ECONOMIC DEVELOPMENT IN MAICHAU DISTRICT, VIETNAM .... 20

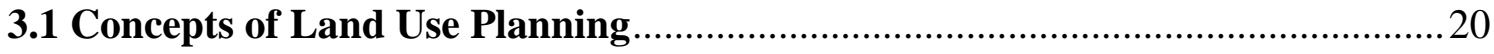

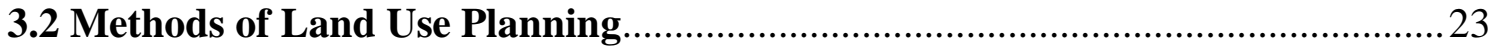

3.2.1 FAO approach and guidelines for Land Use Planning ............................2 23 


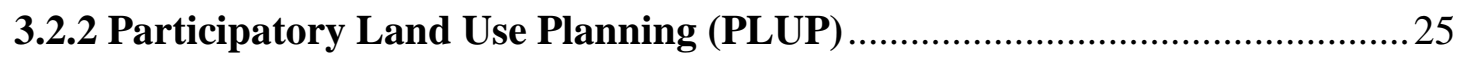

3.2.3 Land Use Planning and Analysis System (LUPAS) …............................2 27

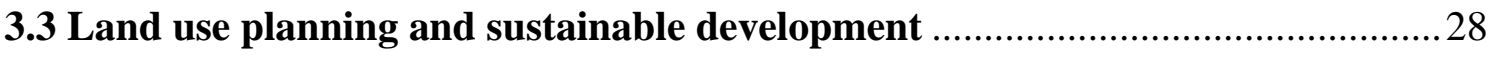

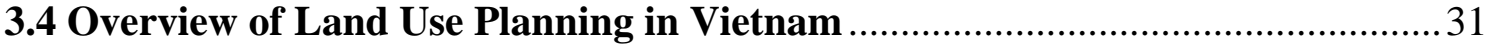

3.5 Correlation between LUP and socio-economic development in Maichau District,

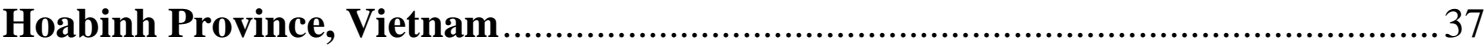

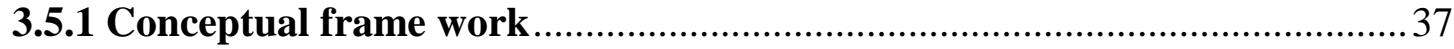

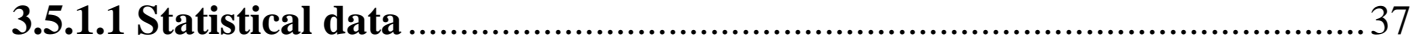

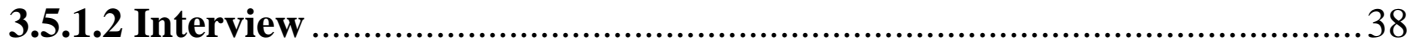

3.5.2 The results of LUP in Maichau District, Hoabinh Province, Vietnam .........39

3.5.3 Correlation between LUP and socio-economic development ......................4 43

3.5.3.1 Correlation between LUP and food security ........................................4 43

3.5.3.2 Correlation between LUP and population growth ............................ 44

3.5.3.3 Correlation between LUP and industrial development........................ 45

3.5.3.4 Opinion of resource managers and officials .....................................49

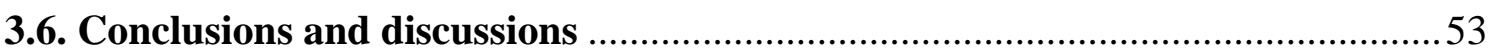

CHAPTER 4: LANDSLIDE SUSCEPTIBILITY IN MAICHAU DISTRICT,

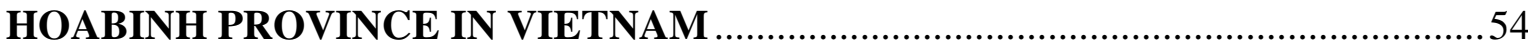

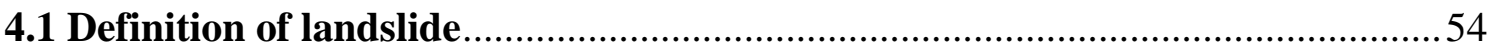

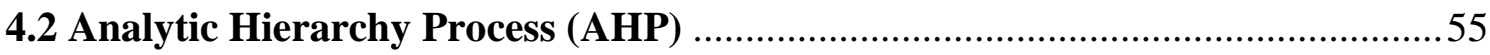

4.3 Determination of landslide susceptibility in Maichau District, Hoabinh

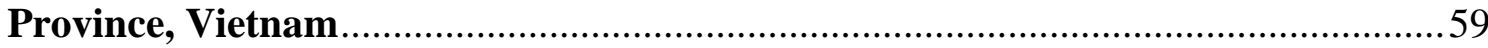

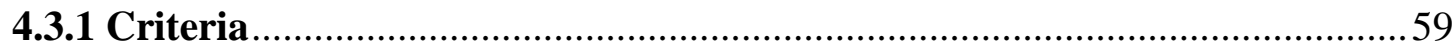

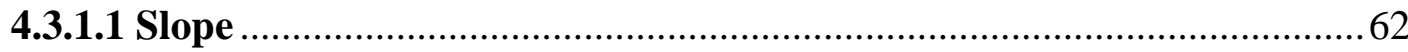

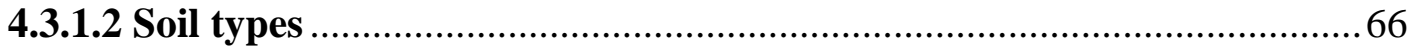

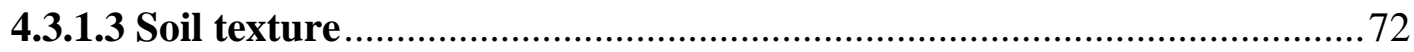

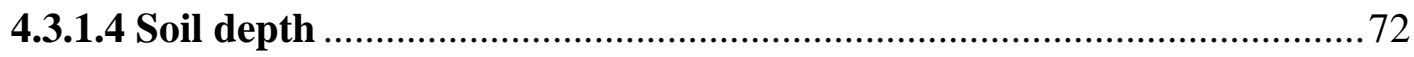

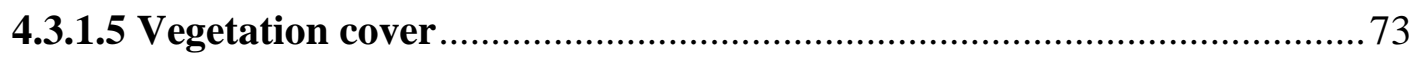




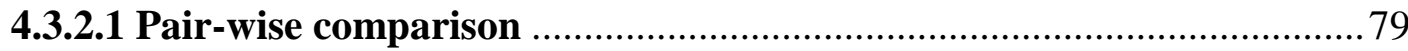

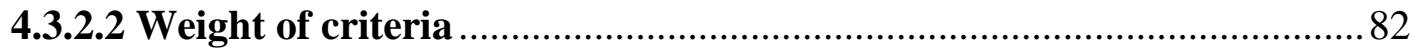

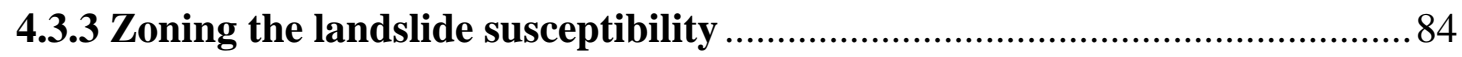

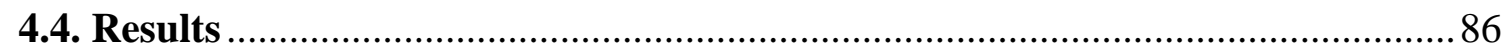

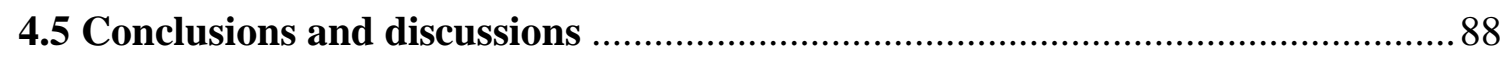

CHAPTER 5: INTEGRATION OF LANDSLIDE SUSCEPTIBILITY INTO LUP AN ECONOMIC CASE STUDY IN MAICHAU DISTRICT, VIETNAM ................90

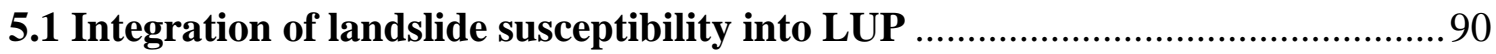

5.1.1 Overview of Geographic Information System (GIS) …............................. 90

5.1.2 Integration of landslide susceptibility into LUP in Maichau District ..........91

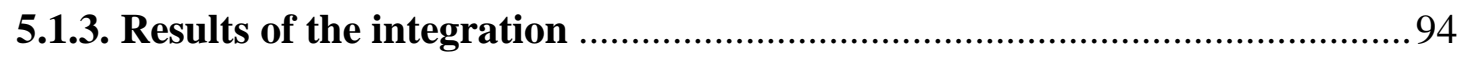

5.2 Actual landslides in Maichau District (2000 - 2010) and overlapping with

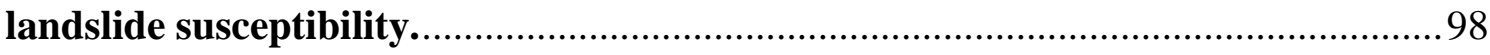

5.2.1 Actual landslide events in Maichau District from 2000 to 2010 ..................98

5.2.2 Overlapping between actual landslides and landslide susceptibility ......... 100

5.3 Benefit of integration of landslide susceptibility into LUP ............................ 103

5.3.1 Simple cost-benefit analysis model of the integration .............................. 103

5.3.2 Benefits of avoided damage of correctly predicted landslides................... 104

5.3.2.1 Damage of actual landslides on agriculture .................................... 108

5.3.2.2 Damage of actual landslides on forest ........................................... 110

5.3.2.3 Damage of actual landslides on residential area .............................. 113

5.3.2.4 Damage of actual landslides on road system ................................... 116

5.3.3 Costs of integration of landslide susceptibility into LUP ….................... 117

5.3.3.1 Cost of making landslide component ............................................... 118

5.3.3.2 Cost of change the residential locations and agricultural crops.......... 120

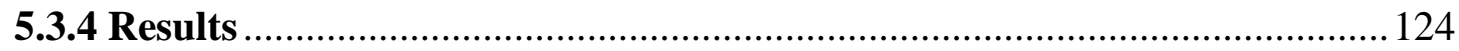


5.4 Conclusions and discussions

CHAPTER 6: GENERAL CONCLUSIONS AND RECOMMENDATIONS

6.1 General conclusions

6.2 Recommendations and policy implications

REFERENCES

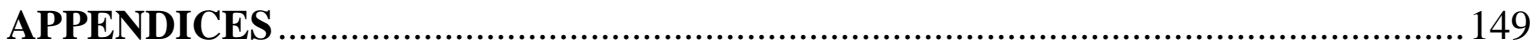




\section{List of Tables}

Table 2.1 Climate in Maichau District, Hoabinh Province (1995-2009) .............................. 8

Table 2.2 Results of socio-economic development in Maichau District ........................... 12

Table 2.3 Area and proportion of current land use in 2010 in Maichau District ................ 17

Table 3.1 Results of land use planning implementation from 2000 - 2010 ........................41

Table 3.2 Correlation between LUP and social economic development ...........................47

Table 3.3 Correlation between intended change and actual change of land use .................48

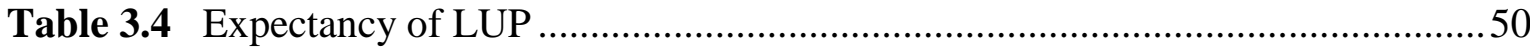

Table 3.5 Descriptive statistics of interview of communal officials.................................51

Table 3.6 Correlation between LUP and contribution of LUP to socio-economic

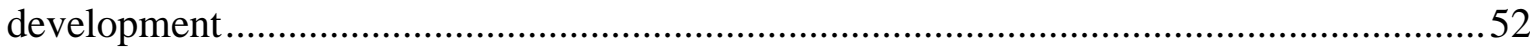

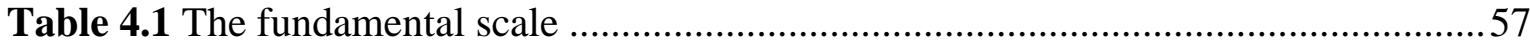

Table 4.2 Categories of slope in Maichau District - Hoabinh Province ..............................63

Table 4.3 Soil types in Maichau District - Hoabinh Province ............................................66

Table 4.4 Results of soil profile analysis of Dystric - Fluvisols ......................................67

Table 4.5 Results of soil profile analysis of Calcic - Fluvisols .......................................69

Table 4.6 Results of soil profile analysis of Rhodic - Ferralsols...................................... 70

Table 4.7 Results of soil profile analysis of Ferralic - Acrisols ..................................... 70

Table 4.8 Results of soil profile analysis of Gleyic - Acrisols ....................................... 71

Table 4.9 Results of soil profile analysis of Humic - Acrisols ....................................... 71

Table 4.10 Categories of soil texture in Maichau District - Hoabinh Province .................. 72

Table 4.11 Categories of soil depth in Maichau District - Hoabinh Province.....................73

Table 4.12 Step and map scale of land use inventory in Vietnam .................................... 76

Table 4.13 Categories of vegetation cover in Maichau District - Hoabinh Province..........76

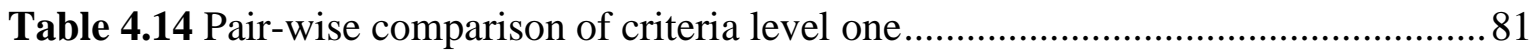

Table 4.15 Pair-wise comparison of sub-criteria of slope (level two) .............................. 81 
Table 4.16 Pair-wise comparison of sub-criteria of soil types (level two) ........................ 81

Table 4.17 Pair-wise comparison of sub-criteria of soil depth (level two) ........................ 82

Table 4.18 Pair-wise comparison of sub-criteria of soil texture (level two)...................... 82

Table 4.19 Pair-wise comparison of sub-criteria of vegetation cover (level two) ..............82

Table 4.20 Weight of criteria to determine landslide susceptibility in Maichau District ... 83

Table 4.21 Pair-wise comparison of landslide susceptibility classification........................ 85

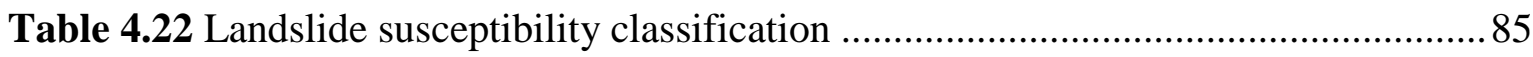

Table 5.1 Alternatives of integration of landslide susceptibility into LUP.......................93

Table 5.2 Suitability category of land use types in Maichau District ................................95

Table 5.4 Damage of actual landslides $\mathrm{ha}^{-1}$ on agriculture $(2000-2010)$........................ 109

Table 5.5 Damage of actual landslides on Acacia ha ${ }^{-1}$ in Maichau District .....................111

Table 5.6 Damage of actual landslides on Bamboo ha ${ }^{-1}$ in Maichau District....................112

Table 5.7 Damage of actual landslides on residential area (2000-2010) .........................115

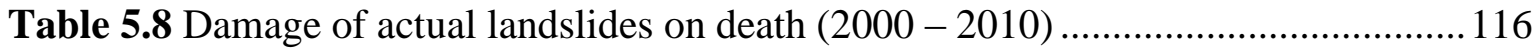

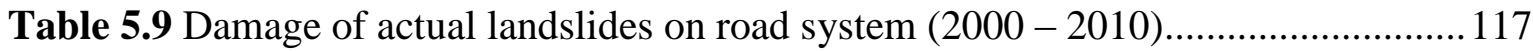

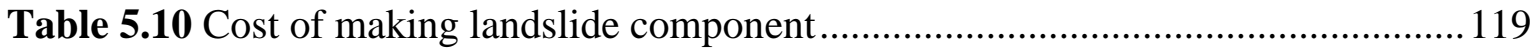

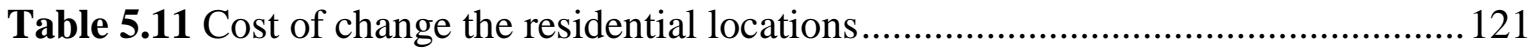

Table 5.12 Loss of land use change from agriculture to forest for the period of 14 years 122 


\section{List of Figures}

Fig.2.1 Location of the research area..........................................6

Fig.2.2 Average temperature from 1995 to 2009, in Maichau district......................9

Fig.2.3 Average rainfall from 1995 to 2009 , in Maichau district...................... 10

Fig.2.4 Mean relative humidity from 1995 to 2009 , in Maichau district...................10

Fig.2.5 Climatic diagram of Maichau district, Hoabinh Province.......................11

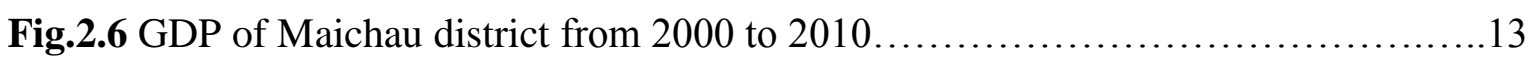

Fig.2.7 Map of land use in 2010 in Maichau district..................................19

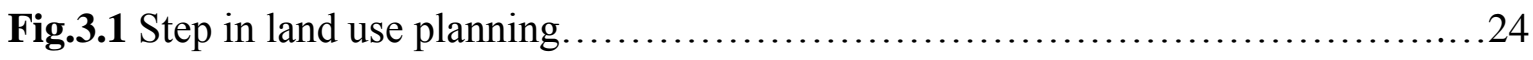

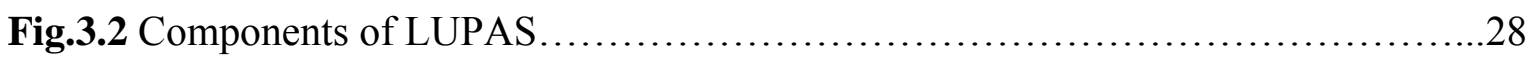

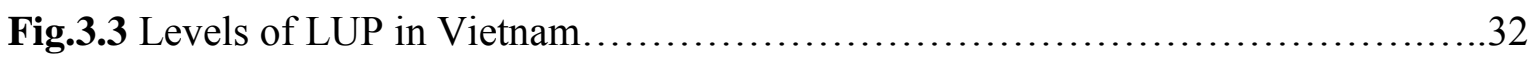

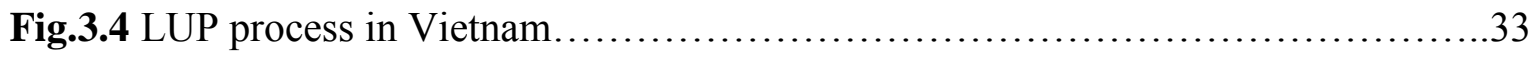

Fig.3.5 Key factors influencing LUP in Vietnam............................... 34

Fig.3.6 Conceptual framework to determine the correlation..........................39

Fig.3.7 Comparison between different land use types in LUP .......................40

Fig.3.8 Comparison between area of land uses in LUP and area of actual land uses.......40

Fig.3.9 LUP map in Maichau District........................................ 42

Fig.3.10 Annual crop land and food production.................................44

Fig.3.11 Correlation between residential land and population growth..................45

Fig.3.12 Correlation between industrial land and value of industry $\ldots \ldots \ldots \ldots \ldots \ldots \ldots \ldots . \ldots 6$

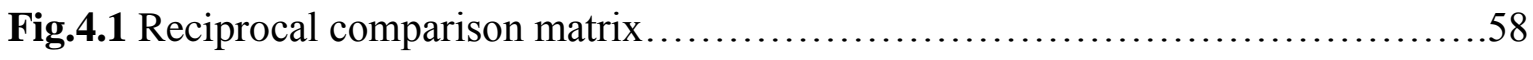

Fig.4.2 Digital Elevation Model of Maichau District................................64

Fig.4.3 Slope map of Maichau District........................................65

Fig.4.4 Soil map of Maichau District.............................................68

Fig.4.5 Process of land inventory in Vietnam................................... 75 
Fig.4.6 Vegetation cover in 2000, in Maichau District. 78

Fig.4.7 Hierarchy structure to determine landslide susceptibility in Maichau District......80

Fig.4.8 Category of landslide susceptibility in Maichau district...................... 86

Fig.4.9 Map of landslide susceptibility in Maichau District..........................87

Fig.5.1 Overlapping thematic maps............................................. 92

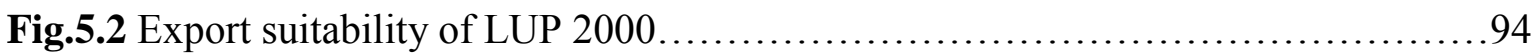

Fig.5.3 Integrated map in Maichau District......................................97

Fig.5.4 Number of actual landslide events from 2000 to 2010, in Maichau District.........98

Fig.5.5 Statistics landslide's area from 2000 to 2010, in Maichau District..................99

Fig.5.6 Location of actual landslide events from 2000 to 2010, in Maichau District......102

Fig.5.7 Landslide damage cost $\mathrm{ha}^{-1}$ on forest, in Maichau District.....................113

Fig.5.8 Comparison NPV between agricultural crops and bamboo..................121

Fig.5.9 Comparison net income between agricultural crops and bamboo..............122

Fig.5.10 Landslide damage cost in Maichau district.............................124

Fig.5.11 Net benefit of the integration of landslide susceptibility into LUP ............125 


\section{List of Abbreviations}

AHP

CBA

DEM

DETR

EAA

EIA

FAO

GDP

GIS

GPS

GSO

$\mathrm{Ha}$

HUA

IPCC

LMUs

LS

LU

LUP

LUPAS

LUT

MCE

Met

MoNRE

NPV

PLUP

PPP

PRA

SEA

SEMLA

SysNet
Analytic Hierarchy Process

Cost Benefit Analysis

Digital Elevation Model

Department of the Environment, Transportation, and the Regions

Equivalent Annual Annuity

Environmental Impact Assessment

Food and Agriculture Organization

Gross Domestic Product

Geographic Information System

Global Positioning System

General Statistical Office

Hectare

Hanoi University of Agriculture

Intergovernmental Panel on Climate Change

Land Mapping Units

Landslide

Land Use

Land Use Planning

Land Use Planning and Analysis System

Land Use Type

Multi-Criteria Evaluation

Meteorological

Ministry of Natural Resources and Environment

Net Present Value

Participatory Land Use Planning

People's Participation Programme

Participatory Rural Appraisal

Strategic Environmental Assessment

Strengthening Environmental Management and Land Administration

Eco-regional Land Use Planning in Tropical Asia 
UN

UNDP

UNEP

VND

WB

WCED
United Nations

United Nations Development Programme

United Nations Environment Programme

Vietnam currency unit (Vietnamese Dong)

World Bank

World Commission on Environment and Development 


\section{CHAPTER 1: INTRODUCTION}

\subsection{General background}

Land Use Planning (LUP) is a systematic assessment of the potential of land and water resources subject to economic and social conditions in order to select suitable land use options. It should account for current land use needs, as well as safeguarding resources for future use (FAO, 1993). Therefore, LUP can be considered as one of the most important approaches for long-term sustainable development at both the regional and national levels. Based on different development scenarios, LUP shall help groups of stakeholders to organize the utilization of land resources in a way that fosters socio-economic development (Counsell \& Haughton, 2006). LUP is understood as the planning for the allocation of activities to land areas to benefit human kind (Crowley et al., 1975). In this regard, LUP can contribute significantly to economic development in the future, by systematically shaping industrialization and urbanization, both of which are major driving forces contributing to land-use change (Long et al., 2007). In addition, a systematical LUP is able to contribute positively to sustainable development within agricultural landscapes, particularly in frontier landscapes. This is particularly important in the rural areas of developing countries where the population depends mostly on agricultural income (Counsell \& Haughton, 2006). Moreover, LUP needs to form a "bridge" connecting different scales from the national to commune level to facilitate sustainable development in public administration hierarchies (Bristow, 1981; Kelly, 2004: p43).

Recently, landslides have been among the most hazardous natural disasters (Guzzetti et al., 1999). Many studies on landslides and their impacts have been carried out in different countries with various methods, including: GIS, remote sensing, AHP, and landslide inventory analysis (Chau et al., 2004; Domínguez-Cuesta et al., 2007; Komac, 2006; Lee et al., 2002; Lee \& Dan, 2005; Neuhäuser \& Terhorst, 2007). The damages of landslides on resident areas, infrastructures and even human casualties have been increasing worldwide (Singhrog et al., 2004 cited by Neuhäuser and Terhorst (2007)). The impacts of landslides on socio-economic development are potentially very large. Landslides can damage urban (Chau et al., 2004) or rural areas and they cause thousands of deaths and injuries. Furthermore, landslides are able to bury agricultural and forest land influencing local production. 
Landslides are trigged by events, such as: earthquakes, rainfall and rapid snowmelt. They are influenced by multiple factors: topography, the soil and rock types, geologic fractures, etc. (Guzzetti, 2000; Sidle \& Ochiai, 2006: p9; Varnes, 1984). According to Guzzetti et al. (1999), landslides in a specific area do not only depend on the natural condition, but also on land-uses and other human activities. Neuhäuser and Terhorst (2007) stated that the landslide susceptibility assessment has become a major concern for authorities who are responsible for regional land use planning and environmental protection. To determine the damage of landslide, a growing research effort has been dealing with the creation of susceptibility or hazard maps which describe the actual or future threat from landslides. Landslide hazard maps are a great help to planners and engineers for choosing suitable development sites (Lee \& Dan, 2005; Pradhan et al., 2008).

In Vietnam, the economy has changed significantly from a bureaucratic and centralized planning economy to the market-oriented system after the opening of the country since 1986. The average annual GDP growth was very high (7.3\% from 1995 to 2005) (WB, 2008). The economic transition has resulted in profound changes in the organization of different sectors of the Vietnamese economy. Associated with the changes of organization, LUP in Vietnam has become more helpful with the plans being less rigid and taking into account market factors (Quang, 2003: p7-9).

During this period of strong economic growth, LUP was mainly used to facilitate economic development (Trung et al., 2004). This focus resulted in damages to the environment, such as erosion in the uplands and soil degradation in the low lands. The Vietnam Land Law regulated that land use should be in accordance with Land Use Planning (Article 11) (Anonymous, 2003). This means that land use change in Vietnam should be proposed in LUP, and then implemented by land users. In addition, some climatic factors, such as, temperature, rainfall, and humidity have increasingly fluctuated affecting largely the land use and human activities not only in Vietnam, but also all over the world. Thus, associated with a great contribution to economic development, current LUP practice in Vietnam is still limited by the environment (SEMLA, 2009). Actually, with three-quarters of Vietnam's territory being mountainous with high rainfall, landslides occur frequently. Therefore, actual landslides should be investigated to see if current LUP practice in Vietnam can be improved if the susceptibility of landslide risks is incorporated into LUP. 
Maichau District is a mountainous area with it's a complex terrain. Relatively close to Vietnam's capital Hanoi; it was conveniently selected to serve as a case study region. The district's LUP was made in 2000 without an analysis of landslide susceptibility although landslides happened frequently in the past, and damaged the local living conditions. The question is that whether or not the land use types in LUP are suitable to protect the environment in long term? Which trends of land use change can be supported in the future period? If landslide susceptibility is integrated into LUP, will local land users in the district gain the benefit?

The research findings are expected to contribute scientifically to the integration of environmental factors into LUP in Vietnam, specially, to improving LUP process and implementation. Hopefully, the learnt lessons can be applied and implemented in different LUP's levels and other regions in Vietnam. At an applied level, this study aims at contributing to an improvement of LUP directly at Maichau District. The expected results on landscape susceptibility can be consulted by local land users to propose and assess proper future land use options.

\subsection{Research objectives}

In this dissertation, I investigate a regionally adapted way to integrate landslide susceptibility into Land Use Planning. Any such integration has technical as well as social and economic implications. Technically, the susceptibility of a particular area to be affected by a landslide must be quantified in a precise and reliable manner. Next, an algorithm needs to be proposed how a spatially explicit rating of landslide susceptibility affects the assignment of potential land uses in LUP. Finally, the economic question matters, how much resources need to be spend on such an integration process, how much landslide damage could be avoided - but also how much productive land use may be affected negatively.

\subsubsection{Main objective}

The main objective of the study is contributing to improved LUP in Vietnam by documenting, how - and at with which costs and benefits - landslide risks can be 
integrated into LUP in the country using a district level case study approach.

\subsubsection{Specific objectives}

(1) The inclusion of landslide risk into LUP is of economic benefit only if actual land use is sufficiently influenced by LUP. To see if LUP makes a difference at all, it is useful to demonstrate the correlation between LUP and the following influences on socio-economic development during the past period of 10 years planning (2000-2010). Thus, the impact of LUP on socio-economic development will be evaluated.

2 Analyzing landslide susceptibility at district level.

- Gathering necessary data for determination of landslide susceptibility in the selected research area.

- Determining landslide susceptibility by using an Analytical Hierarchy Process (AHP) method.

- Integrating landslide susceptibility analysis into LUP.

3 Determining the benefit of the integration of landslide susceptibility into LUP.

- Determining the benefit of integrated LUP: Where have landslides occurred during the past 10 years in the research area? Which of the occurred landslide would have been avoided if the integrated LUP had been used? Which of the occurred landslides would have resulted in less damage if the integrated LUP had been used? In terms of economics, the damage of the occurred but potentially avoided landslides is quantified.

- Determining the costs of integrated LUP: The incorporation of landslide risks may change the location of settlements or agricultural pots. These changes vs. the former plan would have had a cost that needs to be assessed. In addition, the more complex integrated LUP has higher cost that needs to be quantified.

- Analyzing the economic implications of integrated LUP from a landslide risk 
and environmental economics perspective.

4 Drawing some implications for LUP in the future, particularly for land users, planners, and decision-makers.

\subsection{Structure of the thesis}

The subsequent chapters in this thesis are organized, as follows 6 chapters:

Chapter 1 introduces the topic of the research and the general background. It presents the main and specific objectives of the study.

Chapter 2 describes the research area, including: location, topography, climate, socioeconomic conditions, and land use.

Chapter 3 reviews methods of LUP as well as the current state of LUP in Vietnam. The conceptual framework and correlation between LUP and socio-economic development are analyzed as well.

Chapter 4 presents the determination of landslide susceptibility in Maichau District, as follows: review of the landslide definition, and AHP method. Some criteria to determinate the landslide susceptibility are gathered and described. The results of landslide susceptibility analysis are presented.

Chapter 5 examines the benefit of integration of landslide susceptibility into LUP. An analysis of the actual landslides that occurred during the years 2000-2010 is presented. Finally, the total landslide damage cost, the avoided landslide damage cost and the net benefit of the integration of landslide risks are evaluated by simple cost-benefit analysis.

Chapter 6 gives the general conclusions and draws some suggestions and recommendations for land users, authorities and planners. 


\section{CHAPTER 2: CHARACTERISTICS OF THE RESEARCH AREA}

\subsection{Location and area}

Maichau District is located in the northwest region of Vietnam and in the western part of Hoabinh Province. It ranges from $20^{\circ} 24^{\prime}$ to $20^{\circ} 45^{\prime}$ North Latitude and $104^{\circ} 31^{\prime}$ to $105^{\circ} 16$ East Longitude with a total area of $568 \mathrm{~km}^{2}$. The district is one of the 11 districts of Hoabinh Province, and lies along the national road No 6.

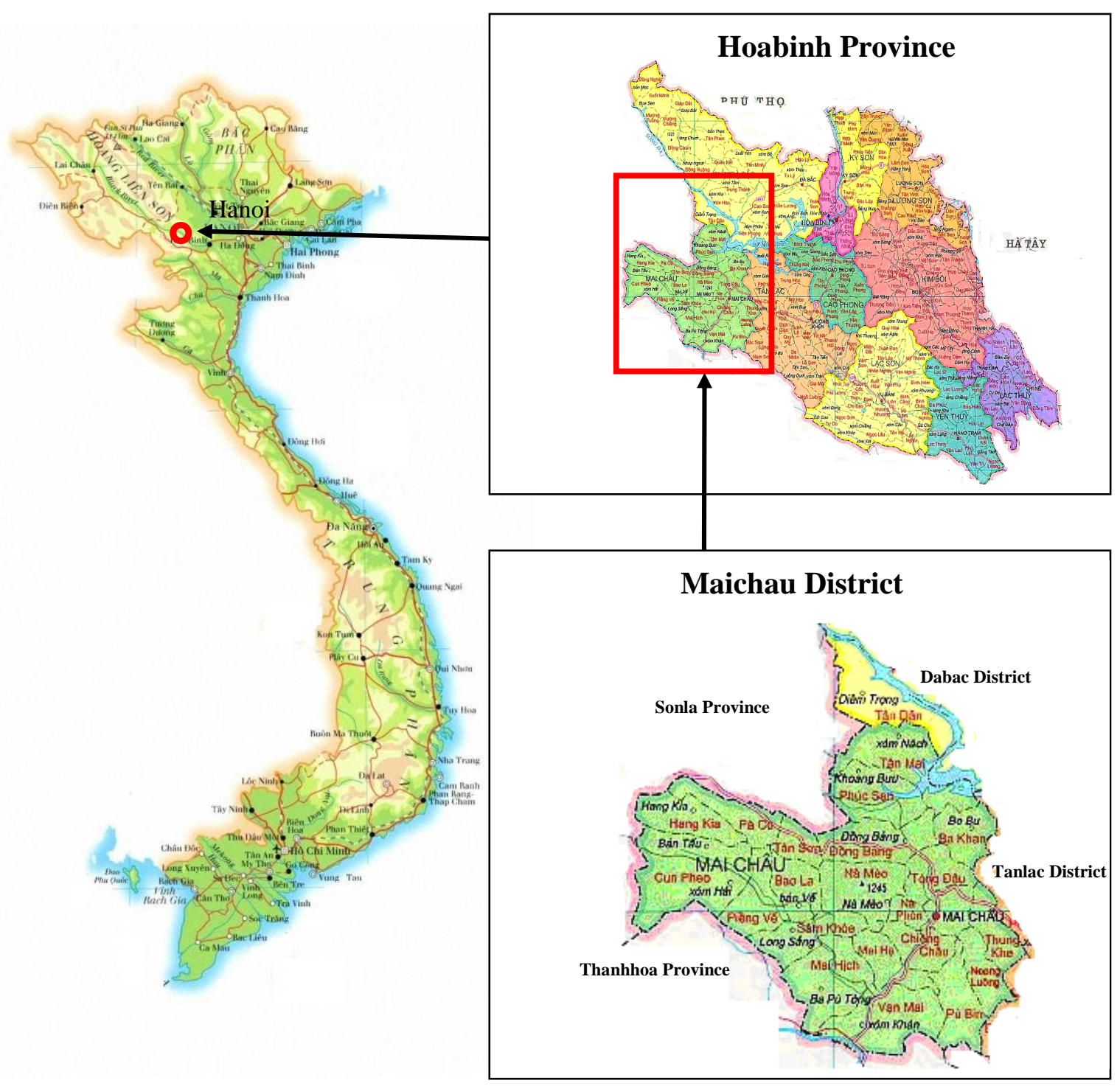

Fig.2.1 Location of the research area

Source: www.commos.wikipedia.org 
The district is situated about $150 \mathrm{~km}$ from Hanoi, and roughly $65 \mathrm{~km}$ from Hoabinh city (the capital of the province) (Anonymous, 2001: p4). It shares borders with Dabac District to the North, Thanhhoa Province to the South, Tanlac District to the East, and Sonla Province to the West (Fig.2.1).

Maichau District is administratively divided into 22 communes and one town (the capital of the district). Located in the mountainous and attractive region of the province with many beautiful landscapes and traditional customs, the district is considered as one of the most beautiful districts of Hoabinh Province and northwest region of Vietnam. Moreover, the location of the district is also a crucial bridge between Hanoi and other provinces in the northwest region of Vietnam (Anonymous, 2001: p14).

\subsection{Terrain}

Located in a complicated terrain dissected by streams and high mountains, basically sloping down from Northeast to Southwest, Maichau is made up of two distinct ecological zones: mountainous area and narrow plain. The mountains cover more than $80 \%$ of the total area of the district. The topography is generally steep and rugged. Forest areas dominate this zone. The narrow plains are interspersed into mountains. Agriculture dominates as the main source of income for local people in the district (Anonymous, 2001: p11). Elevation ranges from 5 meters to 1521 meters above sea level. The average elevation is from $800 \mathrm{~m}$ to $900 \mathrm{~m}$. The highest peak is found with 1521 meters in Paco commune. More than $60 \%$ of Maichau District has slope above $15^{\circ}$ (see slope map in fig.4.3).

\subsection{Climate}

The climate of Maichau District is similar to that of northern Vietnam in general. The weather is submitted to the tropical monsoon climate that is divided into 4 distinct seasons. The spring is cool and drizzly, the summer is hot and dry with westerly winds, the autumn is cool, and winter is cold and wet. The rainy season lasts from May to October. The hottest months and the largest rainfall are usually from May to September. The dry season is from November to coming April; it has the lowest rainfall, the lowest temperature, and 
fog that often can impact seriously on local productions, in particular, agricultural activities (Anonymous, 2001: p5).

According to statistical weather data from 1995-2009 at the meteorological (Met) station located in Maichau District, temperature, rainfall, and relative humidity levels are as follows:

Table 2.1 Climate in Maichau District, Hoabinh Province (1995-2009)

\begin{tabular}{lccccccc}
\hline \multirow{2}{*}{ Month } & \multicolumn{3}{c}{ Temperature $\left({ }^{\circ} \mathrm{C}\right)$} & Relative humidity $(\%)$ & \multicolumn{2}{c}{ Rainfall (mm) } \\
\cline { 2 - 8 } & Average & $\begin{array}{c}\text { Highest } \\
\text { recorded }\end{array}$ & $\begin{array}{c}\text { Lowest } \\
\text { recorded }\end{array}$ & Average & $\begin{array}{c}\text { Lowest } \\
\text { recorded }\end{array}$ & Average & $\begin{array}{c}\text { Highest } \\
\text { recorded }\end{array}$ \\
\hline January & 17.4 & 36.0 & 5.4 & 80.0 & 32.0 & 6.0 & 21.0 \\
February & 19.6 & 35.4 & 7.3 & 79.0 & 33.0 & 15.0 & 60.0 \\
March & 22.0 & $41 . .5$ & 8.0 & 79.0 & 32.0 & 26.0 & 31.0 \\
April & 25.3 & 40.5 & 15.0 & 80.0 & 32.0 & 89.0 & 65.0 \\
May & 26.8 & 41.8 & 16.6 & 81.0 & 32.0 & 216.0 & 86.0 \\
June & 27.9 & 41.0 & 20.3 & 84.0 & 34.0 & 258.0 & 98.0 \\
July & 27.9 & 40.6 & 22.5 & 84.0 & 34.0 & 305.0 & 139.0 \\
August & 27.3 & 37.0 & 21.0 & 87.0 & 35.0 & 309.0 & 193.0 \\
September & 25.9 & 37.0 & 15.5 & 86.0 & 33.0 & 296.0 & 234.0 \\
October & 24.0 & 37.2 & 13.0 & 86.0 & 33.0 & 167.0 & 310.0 \\
November & 20.8 & 36.0 & 9.0 & 81.0 & 33.0 & 31.0 & 116.0 \\
December & 18.0 & 34.6 & 3.1 & 80.0 & 32.0 & 16.0 & 53.0 \\
\hline \multirow{2}{*}{25.0} & & & & & & \\
\hline
\end{tabular}

Source: Met station (2010)

Temperature: The temperature is high in the study area. The average annual temperature varied from $23.0^{\circ} \mathrm{C}$ to $24.2^{\circ} \mathrm{C}$ from 1995 to 2009 (Fig.2.2), in which the highest temperature was in 1998 with $24.2^{\circ} \mathrm{C}$ and the lowest temperature was in 2008 with $23.0^{\circ} \mathrm{C}$. From 1995 - 2009, the average monthly temperature in a year was $24^{\circ} \mathrm{C}$ ranging from $17.4^{\circ} \mathrm{C}$ in January to $27.9^{\circ} \mathrm{C}$ in June and July (Table 2.1). Notably, the highest temperature 
that was ever recorded was $41.8^{\circ} \mathrm{C}$ in 2003 and $41.5^{\circ} \mathrm{C}$ in 2009 . The lowest temperature ever written was $3.1^{\circ} \mathrm{C}$ in December 1999 and $5.4^{\circ} \mathrm{C}$ in January 2009.

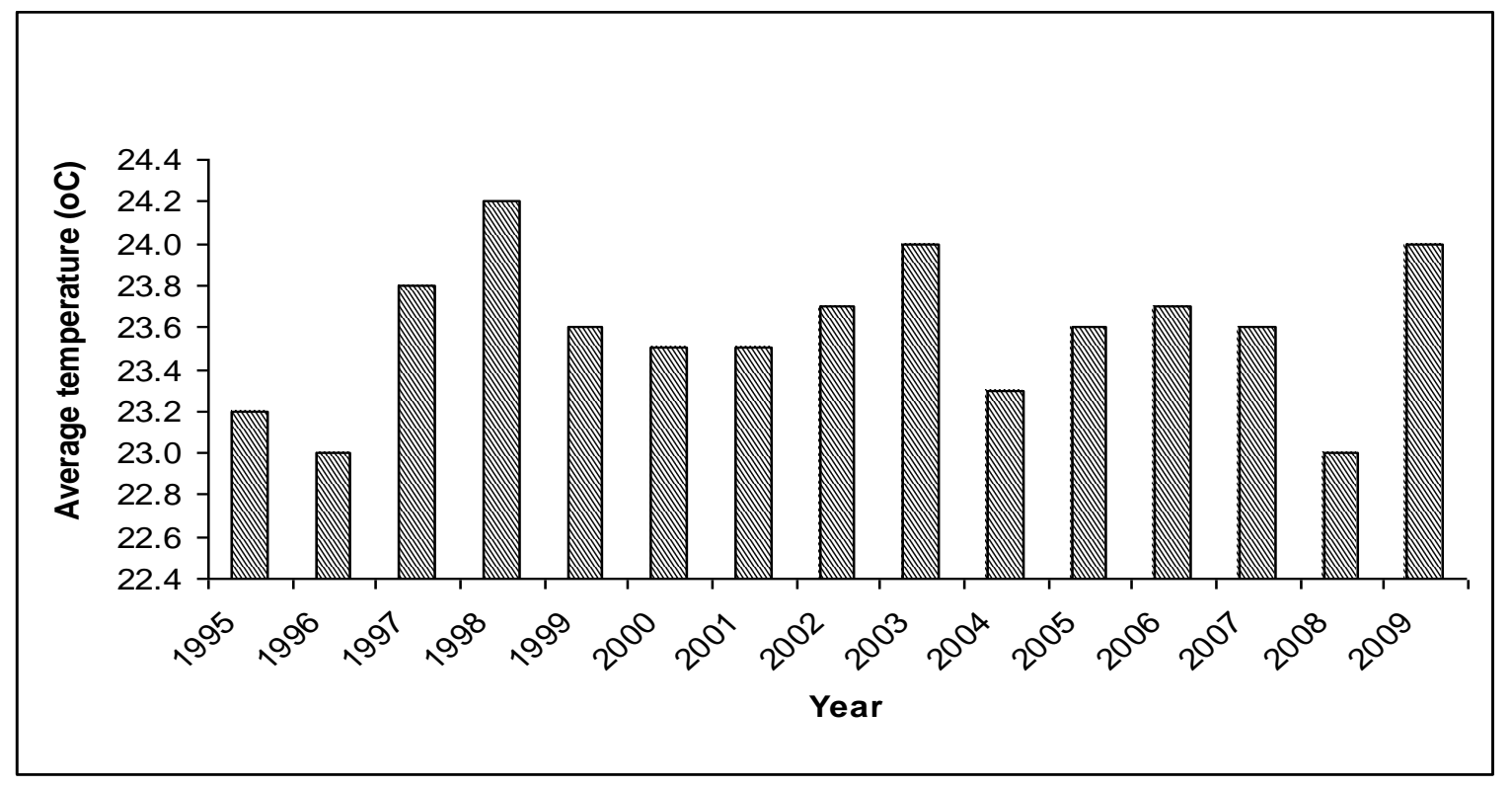

Fig.2.2 Average temperature from 1995-2009 in Maichau District Source: Met Station (2010)

Rainfall: The precipitation in Maichau is high. The average annual rainfall was $1,734 \mathrm{~mm}$, it fluctuated from $1,120 \mathrm{~mm}$ to $2,581 \mathrm{~mm}$ through the period of 15 years (Fig.2.3). The rainfall is concentrated largely from May to October. The highest and lowest rainfall in a month was $309 \mathrm{~mm}$, in August, and $6 \mathrm{~mm}$ in January, respectively (Table 2.1). The highest rainfall a day ever recorded was $350 \mathrm{~mm}$ in July 1996 and $310.4 \mathrm{~mm}$ in October 2007. Thus, in the last decade, the highest rainfall recorded a day was in 2007 , so that it probably affected adversely the erosion, landslide issues in the district. 


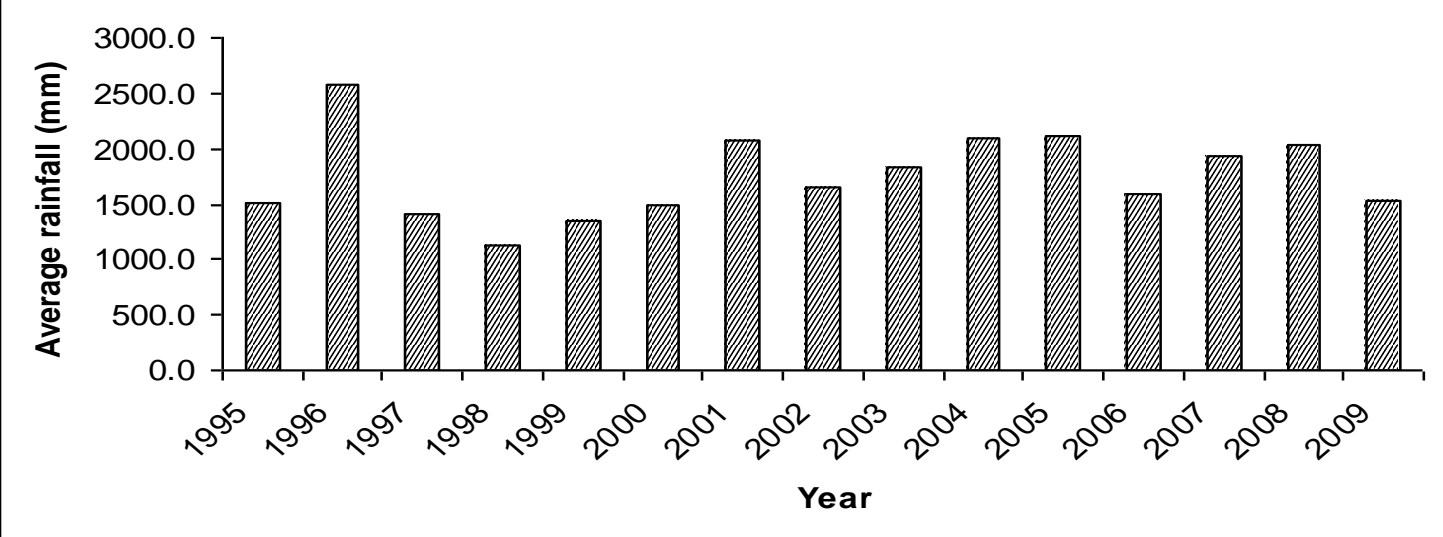

Fig.2.3 Average rainfall from 1995-2009 in Maichau District

Source: Met Station (2010)

Relative humidity: Located in a tropical monsoon climate, the relative humidity in Maichau District is normally high. The average annual relative humidity was roughly $82 \%$, ranging from $80 \%$ to $83 \%$ from 1995 to 2009 . The lowest relative humidity that ever recorded was in December to coming February of 2008 and 2009 at $20 \%$.

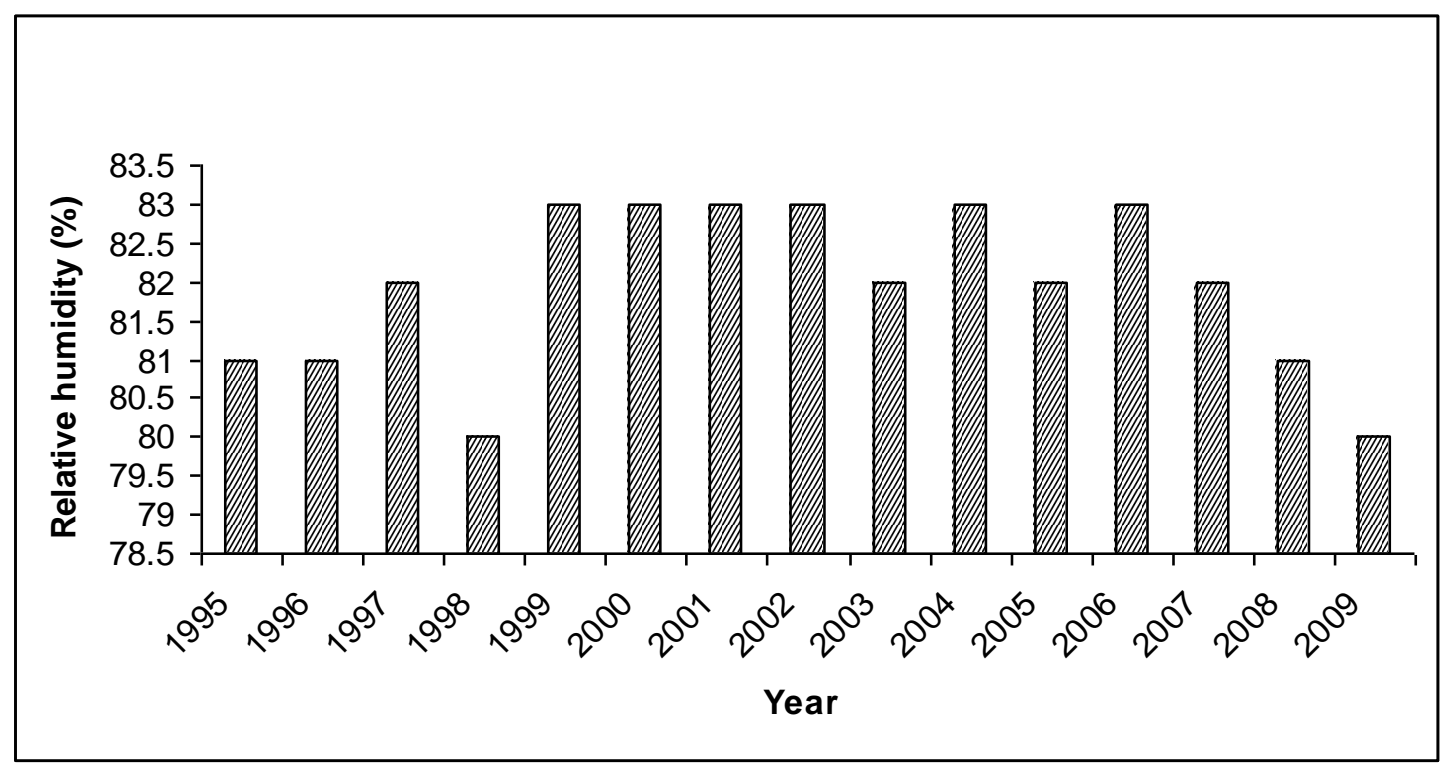

Fig.2.4 Mean relative humidity from 1995-2009 in Maichau District Source: Met Station (2010) 


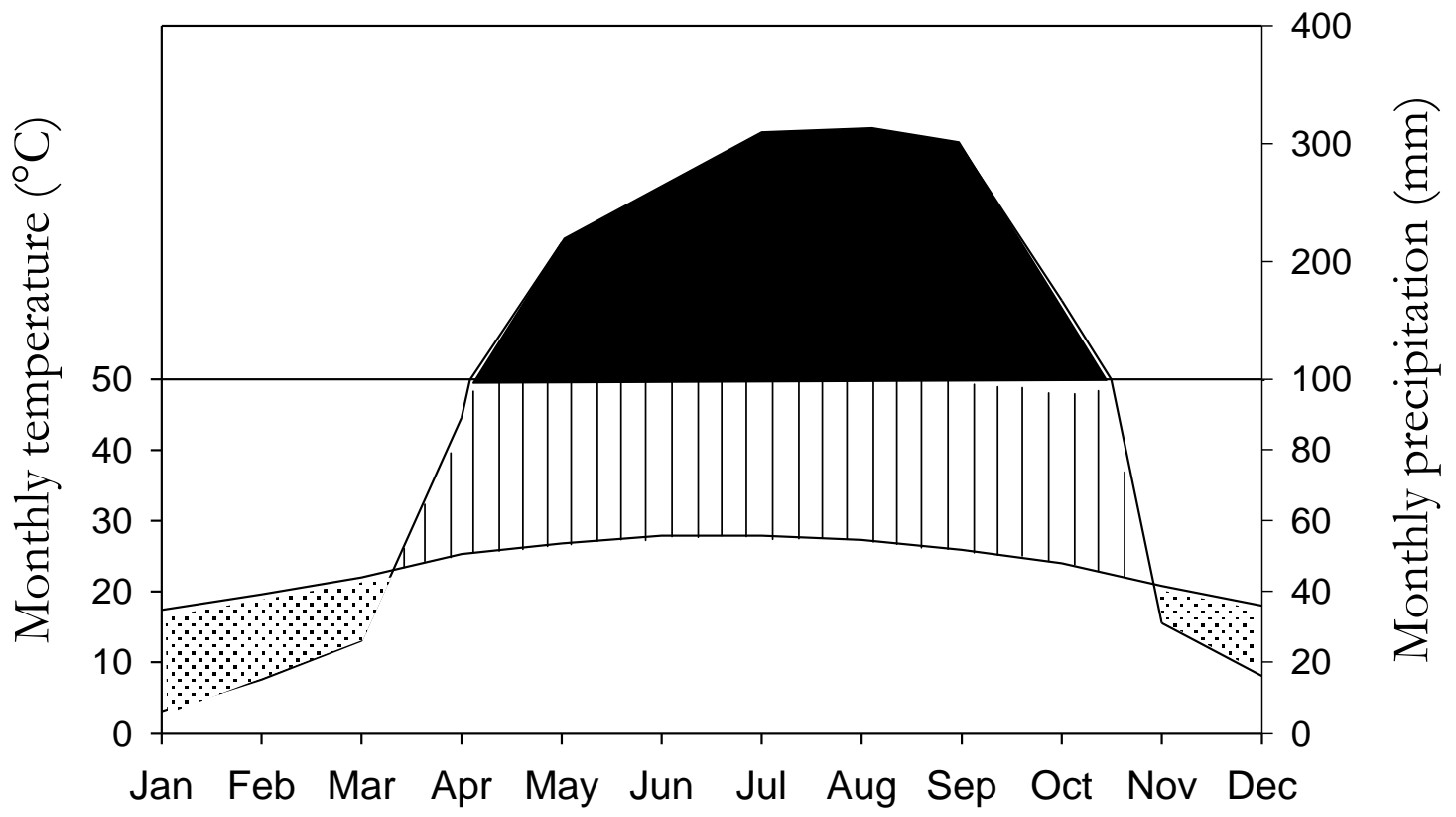

Fig.2.5 Climatic diagram of Maichau District, Hoabinh Province Source: Met Station (2010)

The climatic diagram (fig.2.5) indicates that from May to October the climate in Maichau stood at high relative humidity, in particular, in July, August and September. This could impact largely on land use activities and the ways to protect the land surface.

\subsection{Socio-economic conditions}

\subsubsection{Population and labour}

The population of the district was 52,720 people in 2010 , increased by 5,291 people from the year 2000. Of which roughly $90 \%$ of the population was in rural area and engaged in the agricultural sector and nearly $10 \%$ was working in non-agricultural sectors. The average rate of population growth was $1.12 \%$ from 2000 to 2010 . The population density of the district was 93 persons per square kilometer, while the unit in Hoabinh Province was 173 persons/km² (GSO Maichau, 2001, 2002, 2003, 2004, 2005, 2006, 2007, 2008, 2009, 2010). Thus, Maichau District has a relatively low population density. The majority of the population is the Thai people, accounting for $62.14 \%$ of the total population, with other groups, as follows: Muong: 15\%; Kinh: 12\%; H'Mong: 5\% and others: $5.86 \%$. Each of ethnic group has a separate culture, language and custom. 
The labour force of the district was 26,481 employees in 2010 , accounting for about $50 \%$ of population. Of them, 23,260 employees were working in agriculture, accounting for $88 \%$ of total employees, and 3,221 employees not working in agriculture, equivalent to $12 \%$ of the work force (GSO Maichau, 2010).

\subsubsection{Economic development}

The economy of Maichau used to depend largely on agriculture. It has been transforming from a self-sufficient agricultural economy one to a market-oriented agricultural economy. In the 2001-2010 period, GDP increased by roughly $16 \%$ per year, especially $24.72 \%$ in 2003 (Table 2.2). The income per capita rose rapidly by 4 times from around VND 2.0 million in 2000 to VND 8 million in 2010. Food per capita raised regularly from $278 \mathrm{~kg}$ year $^{-1}$ in 2000 to $485 \mathrm{~kg} \mathrm{year}^{-1}$ in 2010 (GSO Maichau, 2001, 2002, 2003, 2004, 2005, 2006, 2007, 2008, 2009, 2010).

Table 2.2 Results of socio-economic development in Maichau District

\begin{tabular}{rrrrr}
\hline Year & $\begin{array}{c}\text { Population } \\
\text { (Person) }\end{array}$ & $\begin{array}{c}\text { Food (Ton } \\
\text { seed) }\end{array}$ & $\begin{array}{c}\text { Income per } \\
\text { capita (VND } \\
\text { million) }\end{array}$ & $\begin{array}{c}\text { Economic } \\
\text { growth (\%) }\end{array}$ \\
\hline 2000 & 47,429 & $13,212.50$ & 2.01 & 17.37 \\
2001 & 47,483 & $15,576.00$ & 2.15 & 7.04 \\
2002 & 47,950 & $18,630.00$ & 2.53 & 19.00 \\
2003 & 48,650 & $19,578.00$ & 3.11 & 24.72 \\
2004 & 48,839 & $19,967.50$ & 3.64 & 17.39 \\
2005 & 49,277 & $18,284.00$ & 4.11 & 13.96 \\
2006 & 49,533 & $21,876.60$ & 4.68 & 14.49 \\
2007 & 49,744 & $21,476.00$ & 5.70 & 22.29 \\
2008 & 50,241 & $25,468.00$ & 6.74 & 19.42 \\
2009 & 52,584 & $24,467.70$ & 7.27 & 12.83 \\
2010 & 52,720 & $25,607.00$ & 8.00 & 10.50 \\
\hline
\end{tabular}

Source: GSO Maichau, 2001-2010

In the years during which the reform (Doi Moi) was enacted, Vietnam's economic structure has changed due to an increase in the diversification of industries and the development of businesses (Cuong, 2005b: p12). In Maichau District, the economic 
structure also changed rapidly throughout the period from 2000 to 2010 (fig.2.6). Although the share of agriculture in the GDP declined rapidly from $88.76 \%$ in 2000 to $37.72 \%$ in 2010, its value increased from 84.58 billion VND to 159.25 billion VND in ten consecutive years. On the contrary, the share of "non-agriculture" (industry and service) soared from $5.7 \%$ and $5.54 \%$ in 2000 to $26.27 \%$ and $36.01 \%$ in 2010 , respectively. The value of "non-agriculture" rose dramatically by 105.86 billion VND (industry) and 146.72 billion VND (service) (GSO Maichau, 2001, 2002, 2003, 2004, 2005, 2006, 2007, 2008, 2009, 2010).

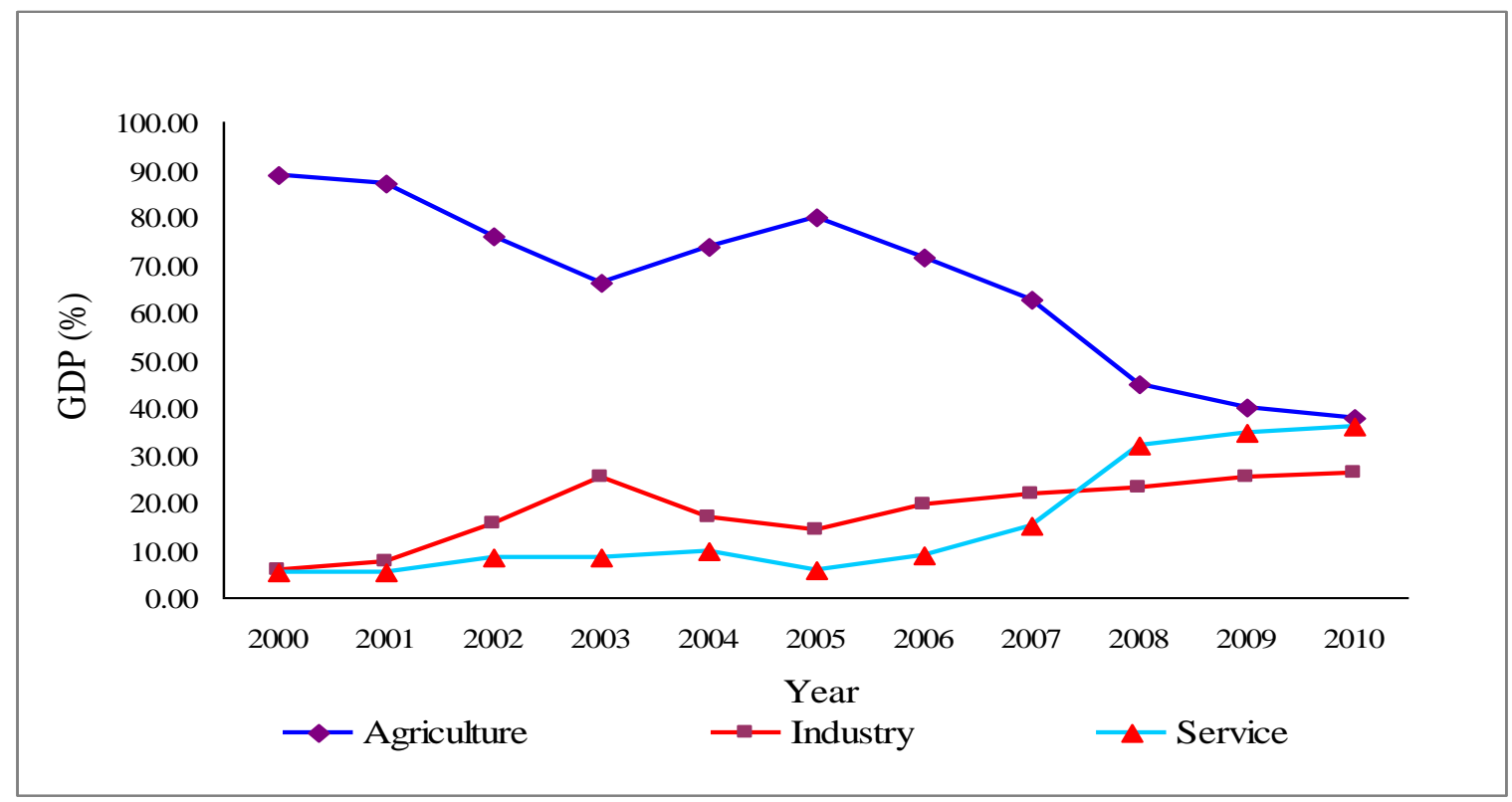

Fig.2.6 GDP of Maichau District from 2000 - 2010

Source: GSO Maichau, 2001-2010

Fig.2.6 shows that the economic structure has transferred largely from agriculture to "nonagriculture" (industry and service). Accordingly, the income of local people also increased from m2.0 VND to m8.0 VND. GDP rose dramatically from 95.3 billion VND to 422.1 billion VND in the period from 2000 to 2010 (GSO Maichau, 2001, 2010). Therefore, the change of economy has probably affected the current land use and will likely affect the different scenarios of land use in Land Use Planning in the next period of development. Possibly, LUP and socio-economic development are correlated. The correlation will be studied in chapter 3. 


\subsubsection{Infrastructure}

Being the mountainous district of Hoabinh Province, the infrastructure of Maichau has some limitations for development and lives of local people.

The road system in Maichau is classified into 4 categories: National, provincial, district and communal roads with a total length of $58.5 \mathrm{~km}, 59.2 \mathrm{~km}, 114.26 \mathrm{~km}$ and $352.6 \mathrm{~km}$, respectively (Anonymous, 2010f). The district and communal roads are of poor quality. Notably, in some communes in the highest area of the district, motorcars and trucks can only reach some of the villages during the dry season, while in the rainy season local people transport their products by foot or horses. In recent years, the development of the road systems has required large financial resources from the government and local people (Anonymous, 2010a).

Irrigation systems are in place to supply water to paddy rice fields in the plains. In order to maintain and improve the irrigation system, large investments are necessary. Obviously, the system has been usually upgraded in the dry season by supports from government and local people (Anonymous, 2010a). It is carried out in the lowland of the district, while crops cultivated on the upland rely on rainfall.

Recently, the water supply for local people has been supported by government, and by foreign aid projects such as the programs 135; 925 and the UNICEP projects, etc. These projects have contributed to an increase in the number of households provided with clean water.

By 2010, all communes of the district were provided with electricity from national sources, in comparison with the year 2000, where there were only $18 / 23$ communes had the electricity (GSO Maichau, 2010). However, some villages located in the very steep area are still living without electricity from national sources.

Healthcare and educational systems are also limited, although they have been invested in largely by government and local people. Indeed, 23/23 communes have a medical station with a total of 20 doctors and 144 nurses, standing at 2,636 people per one doctor (GSO Maichau, 2010). Recently, the educational system has developed significantly under investments of both government and private sections. By 2010, the educational system in Maichau District consisted of garden school (22 schools), primary school (18 schools), 
secondary school (24 schools) and high school ( 2 schools). The universal education at the district was secondary school (GSO Maichau, 2010).

\subsection{Land use}

\subsubsection{Land management}

In association with the economic reform, administrative land management also has changed significantly. Basically, land management in the district has been implemented in accordance with the land law and different regulations of government. The land management belongs to the tasks of the Natural Resources Management and Environment Department in Maichau District, each specific task is presented, as follows (Anonymous, 2003): promulgating legal documents on land management and land use and organising the implementation thereof; determining administrative boundaries; compiling and managing administrative boundary records; drawing administrative maps; surveying, measuring, assessing and classifying land; drawing cadastral maps, current land use maps, and land use planning maps; managing land use planning and plans; managing land allocation, land lease, land recovery, change of land use purposes; registering land use rights; compiling and managing cadastral records; granting land tenure certificates; carrying out land statistics and inventories; managing land-related finance; managing and developing the land use right market in the real estate market; managing and supervising the implementation of rights and obligations by land users; inspecting and examining the compliance with law provisions on land; treating violations of land legislation; settling land disputes; settling complaints and denouncement against violations in land management and land use; administering land-related public services

The main asset of local people is land resource, so the administrative land management is significant in maintaining the stable development and use efficiently of this land resource (Enemark \& Sevatdal, 1999). 


\subsubsection{Current land use in 2010}

Total area of Maichau District was 56,850 ha, accounting for $12.37 \%$ of Hoabinh Province's area. The current land use is presented in table 2.3, as follows:

Agricultural land occupied $12.1 \%$ of the total district, including: land of annual crops $(93.7 \%)$ and perennial crops $(6.3 \%)$. On average, one demographic unit ${ }^{1}$ was $1,218 \mathrm{~m}^{2}$, in comparison with $593 \mathrm{~m}^{2}$ in Hoabinh Province. The main crops cultivated in the district included: rice, maize, cassava, batata, peanut, soybean, and other vegetables as indicated in table 2.4. Perennial plant's land was dispersed in the residential area.

Forest land was 42,834 ha, accounting for $75.3 \%$ of the district, so it was a primary land use. Of which, forest land for production was 33.6\% of forest land, 54.9\% for protection and $11.6 \%$ for special-use.

Residential land was 861 ha, accounting for $1.5 \%$ of the district, including rural area with 825 ha $(95.9 \%)$ and urban area with 35 ha $(4.1 \%)$. Average per capita was $163 \mathrm{~m}^{2}$, in which $68.8 \mathrm{~m}^{2}$ per capita in urban area and $173.7 \mathrm{~m}^{2}$ per capita in rural area.

Land for publish use, including: road, irrigation, education, healthcare was 496 ha, occupying $0.9 \%$ of the district. Although it is not too large, it affects significantly the socio-economic development and live activities.

Water surface was $3.38 \%$ of the district, of which the large part was a hydro electric reservoir.

Unused land was very large with 3,652 ha, accounting for $6.4 \%$ of the district. It has potential to extend for different land uses in the further period of development, like agricultural and forest land, if it is invested and allocated to local people (Anonymous, 2010d).

\footnotetext{
${ }^{1}$ Per capita
} 
Table 2.3 Area and proportion of current land use in 2010 in Maichau District

\begin{tabular}{|c|c|c|}
\hline Land classification & Area (ha) & Proportion $(\%)$ \\
\hline 1 Agricultural land & $6,853.39$ & 12.06 \\
\hline 1.1 Land for cultivation of annual crops & $6,421.54$ & 11.30 \\
\hline Rice & $1,244.51$ & 2.19 \\
\hline Others & $5,177.03$ & 9.11 \\
\hline 1.2 Land for cultivation of perennial crops & 431.85 & 0.76 \\
\hline 2 Forest land & $42,833.77$ & 75.34 \\
\hline 2.1 Land for production forests & $14,384.61$ & 25.30 \\
\hline 2.2 Land for protection forests & $23,500.97$ & 41.34 \\
\hline 2.3 Land for special-use forests & $4,948.19$ & 8.70 \\
\hline 3 Residential land & 861.08 & 1.51 \\
\hline $\begin{array}{l}4 \text { Land for construction of offices, public service } \\
\text { delivery institutions }\end{array}$ & 12.68 & 0.02 \\
\hline 5 Land for national security and defense purposes & 7.82 & 0.01 \\
\hline 6 Land for non-agricultural production and business & 28.07 & 0.05 \\
\hline 7 Land for public use & 496.00 & 0.87 \\
\hline 8 Land used for cemeteries and graveyards & 183.91 & 0.32 \\
\hline $\begin{array}{l}9 \text { Land with rivers, canals, streams and specialized } \\
\text { water surface }\end{array}$ & $1,921.71$ & 3.38 \\
\hline 10 Unused land & $3,651.95$ & 6.42 \\
\hline Total area & $56,850.38$ & 100.00 \\
\hline
\end{tabular}

Source: Anonymous (2010d) 
Table 2.4 Area, Productivity and Crop yield of main crops in Maichau District

\begin{tabular}{|c|c|c|c|c|}
\hline Crops & Unit & 2001 & 2005 & 2010 \\
\hline \multicolumn{5}{|l|}{1 Rice } \\
\hline - Area & ha & $2,422.00$ & $2,026.80$ & $1,965.40$ \\
\hline - Productivity & ton/ha & 3.73 & 4.95 & 5.16 \\
\hline $\begin{array}{l}\text { - Crop yield } \\
2 \text { Maize }\end{array}$ & ton & $9,036.00$ & $10,027.82$ & $10,147.30$ \\
\hline - Area & ha & $3,126.00$ & $4,134.40$ & 5307.30 \\
\hline - Productivity & ton $/$ ha & 2.09 & 1.09 & 2.80 \\
\hline - Crop yield & ton & $6,540.00$ & $7,853.00$ & $14,861.00$ \\
\hline \multicolumn{5}{|l|}{3 Cassava } \\
\hline - Area & ha & 870.00 & $1,184.90$ & 1334.10 \\
\hline - Productivity & ton $/ \mathrm{ha}$ & 8.30 & 8.50 & 8.70 \\
\hline - Crop yield & ton & $7,221.00$ & $10,072.00$ & $11,607.00$ \\
\hline \multicolumn{5}{|l|}{4 Batata } \\
\hline - Area & ha & 106.00 & 146.30 & 132.58 \\
\hline - Productivity & ton/ha & 4.00 & 4.50 & 4.50 \\
\hline - Crop yield & & 424.00 & 659.00 & 596.00 \\
\hline \multicolumn{5}{|l|}{5 Peanut } \\
\hline - Area & ha & 210.00 & 317.90 & 375.90 \\
\hline - Productivity & ton $/ \mathrm{ha}$ & 1.00 & 1.30 & 1.40 \\
\hline - Crop yield & ton & 207.00 & 413.00 & 526.60 \\
\hline \multicolumn{5}{|l|}{6 Soybean } \\
\hline - Area & ha & 414.00 & 154.70 & 84.00 \\
\hline - Productivity & ton/ha & 1.25 & 1.60 & 1.50 \\
\hline - Crop yield & ton & 517.00 & 247.00 & 126.00 \\
\hline \multicolumn{5}{|l|}{7 Vegetable } \\
\hline - Area & ha & 412.00 & 455.31 & 655.00 \\
\hline - Productivity & ton/ha & 3.00 & 3.84 & 4.12 \\
\hline - Crop yield & ton & $1,235.00$ & $1,750.00$ & $2,698.40$ \\
\hline
\end{tabular}

Source: GSO Maichau, 2001-2010 


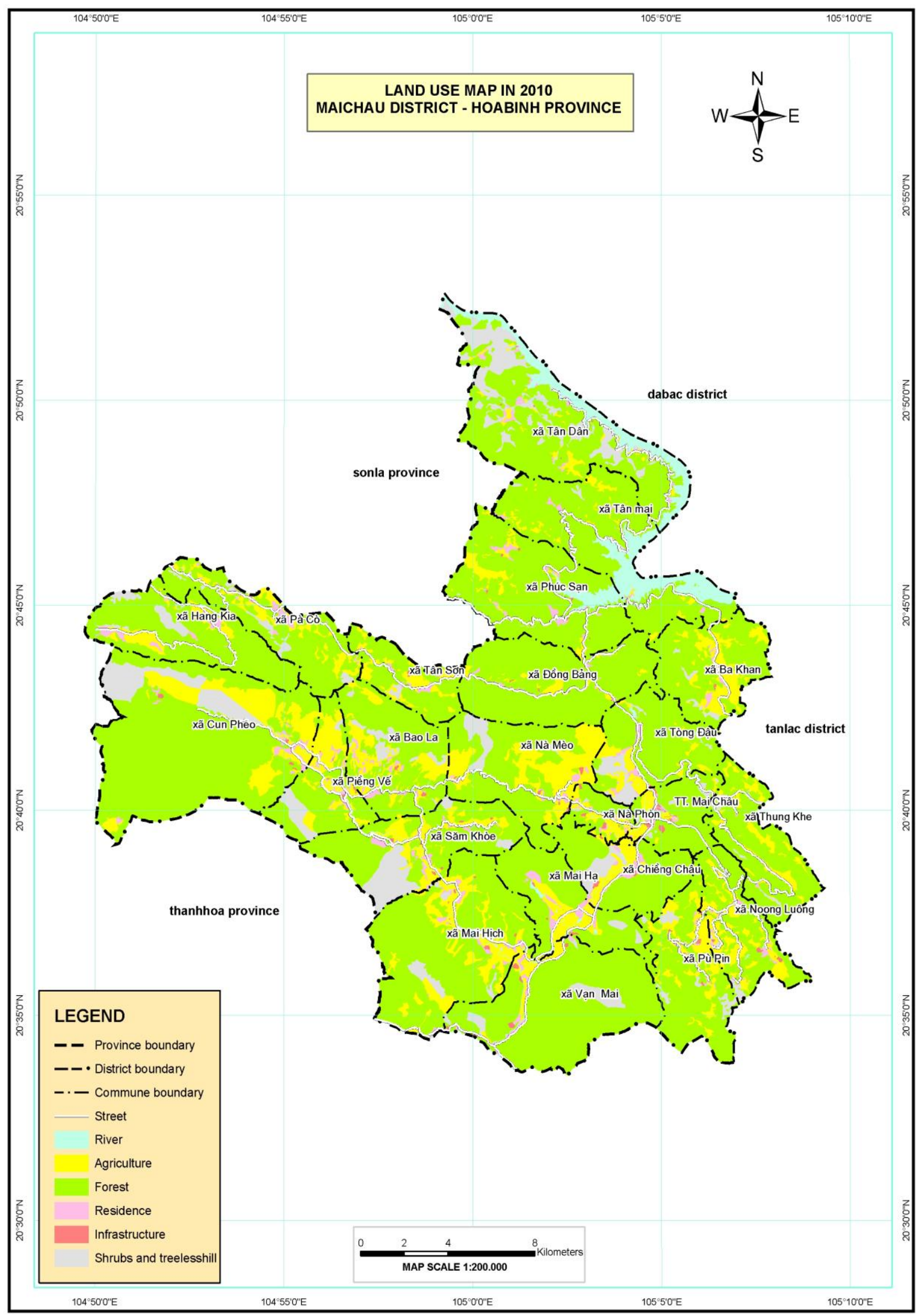

Fig.2.7 Map of land use in 2010 in Maichau District; Source: Anonymous (2010d) 


\section{CHAPTER 3: CORRELATION BETWEEN LAND USE PLANNING (LUP) AND SOCIO-ECONOMIC DEVELOPMENT IN MAICHAU DISTRICT, VIETNAM}

After extensively reviewing the concept and practice of Land Use Planning (LUP), this chapter analyses the correlation between LUP and socio-economic development in Maichau District. This is an important background task: In a transition country and emerging economy such as Vietnam, it is a priori not clear, which force LUP actually exerts on actual development. Because of the high priority that the Vietnamese government places upon economic development, for example, it is conceivable that economic forces exert a much stringer influence that a plan. If there is strong indication that actual development is not correlated to plans, LUP was a lost cause from an economic point of view: More complex LUP would only generate more costs without possibly resulting in any positive change. If, in contrast, a strong influence can be documented, confidence in the entire LUP process would be strengthened - and a potential argument against the relevance of integrating land slide risks into LUP is deflected.

\subsection{Concepts of Land Use Planning}

FAO/UNEP (1997: p9) defined as Land and Land Resources refer to an area of the earth's terrestrial surface, encompassing all attributes of the biosphere immediately above or below this surface, including those of the near-surface climate, the soil and terrain forms, the surface hydrology (including shallow lakes, rivers, marshes and swamps), the nearsurface sedimentary layers and associated groundwater and geohydrological reserve, the plant and animal populations, the human settlement pattern and physical results of past and present human activity (terracing, water storage or drainage structures, roads, buildings, etc.). According to the FAO and UNEP (1999: p8), the basic functions of land in supporting human and other terrestrial ecosystems can be summarized, as follows:

- A score of wealth for individuals, groups, or a community;

- Production of food, fibre, fuel or other biotic materials for human use;

- Provision of biological habitats for plants, animals and micro-organism; 
- Co-determinant in global energy balance and the global hydrological cycle, which are both a source and a sink for greenhouse gases;

- Regulation of the storage and flow of surface water and groundwater;

- Storehouse of minerals and raw materials for human use;

- A buffer, filter or modifier for chemical pollutants;

- Provision of physical space for settlements, industry and recreation;

- Storage and protection of evidence from the historical or pre-historical record (fossils, evidence of past climate, archaeological remains, etc.);

- Enabling or hampering movement of animals, plants and people between one area and another.

Based on the vital role of land, understanding and using it have become the crucial responsibilities of land users, authorities, scientists and planners. People have used naturally land resource for their purposes in order to exist. Therefore, land use is an interaction between the biophysical and human driving forces (Weng, 2010: p348). The ways of using land resources have changed throughout different periods of time. In actual development, an issue is emerging on how to use land resources to meet the needs of present and future generations. Moreover, land use is characterized by the arrangements, activities, and produce in order to change or maintain a certain land cover type (Antonio \& Louisa, 2005). Land use defined in this way establishes a direct linkage between land cover and the people's actions in their environment. Thus, it can be defined as human use of land which involves both biophysical attributes of land and purposes for use of land (Weng, 2010: p346). The pressure on land has gradually increased from different causes (The National Land Use Planning Commission, 1998). The reasons are a growing number of conflicts between the different land users; insecurity of land use and tenure; poor development of land markets; deforestation; increasing migrations of people and livestock.

Land Use Planning (LUP) is a potential solution for sustainable use of land in the long term by optimizing the effective use land resources. According to Crowley et al. (1975: p2) Land Use Planning is defined as planning for the allocation of activities to land areas in 
order to benefit human. The discipline involves three sets of tasks:

- forecasting requirements or demands for goods and services;

- estimating the supply of land available to produce the goods and services (in term of amount, location, quality, suitability, or capability);

- evaluating, implementing and monitoring the alternative management and control strategies;

The aim of LUP is, therefore, to meet the needs of land users and development, including urban (residential, commercial, industrial, institutional), transportation, agriculture, forestry, mining, and outdoor recreation. For instance, in the 1970's people in USA had found the best way to use land for meeting different needs, such as: goods and services through LUP. In addition, LUP had significantly contributed to land management and land use strategies in the long run (Crowley et al., 1975: p10-30). Thus, the relationship between land available and land requirements in an area has been mentioned in both present and future.

To spread worldwide, Food and Agriculture Organization of the United Nations (FAO) (1993) defined it as: "Land use planning is the systematic assessment of land and water potential, alternatives for land use and economic and social conditions in order to select and adopt the best land use options". The purpose is to select and take into practice the land uses that will best meet the needs of the land users as well as safeguarding resources for future. The need for change, the need for improvement of management, and need for a quite different pattern of land use are dictated by changing circumstances.

This definition was, therefore, accepted by its comprehensive contents, including: economic, social and environmental components. In particular, the needs of people for land resources in LUP are permanently met both in present and future, so the participation of local people is noticeably cared for (Huy, 2009: p12).

To understand and clearly apply LUP for sustainable development, FAO and UNEP (1999: p14) proposed a definition of LUP as: "Land-use (or Land Resources) Planning is a systematic and iterative procedure carried out in order to create an enabling environment for sustainable development of land resources which meets people's needs and demands. It 
assesses the physical, socio-economic, institutional and legal potentials and constraints with respect to an optimal and sustainable use of land resources, and empowers people to make decisions about how to allocate those resources".

Working Group on Integrated Land Use Planning defined: "Land use planning is an iterative process based on the dialogue amongst all stakeholders aiming at the negotiation and decision for a sustainable form of land use in rural areas as well as initiating and monitoring its implementation" (Amler et al., 1999)

In short, LUP is understood as a solution in the future for sustainable development and land resources exploitation in the economic, social and environmental dimensions. In addition, LUP has also directly related to public administration and policies (Bristow, 1981; Puginier, 2002: p129). However, understanding and using these definitions of LUP in practice are a concern for planners so as to avoid some misunderstandings that lead to making bad LUP in the future.

\subsection{Methods of Land Use Planning}

Some approaches and methods of LUP have been, actually, proposed and applied in different regions in order to grow land user income and sustainable development. As the numbers of people continue to increase, there is an increasingly urgent need to match land types and land uses in the most rational way possible (FAO, 1993). Some of the methods will be explained below:

\subsubsection{FAO approach and guidelines for Land Use Planning}

The FAO approach and guidelines are to help all involved in the planning process, including: Development, management and conservation of rural development. Land Use Planning described in FAO guidelines 1993 contains 10 steps (Fig.3.1): (1) establish goals and terms of reference; (2) organize the work; (3) analyze the problems; (4) identify opportunities for change; (5) evaluate land suitability; (6) appraise the alternatives: environmental, economic and social analysis; (7) choose the best option; (8) prepare the land-use plan; (9) implement the plan; (10) monitor and revise the plan. 


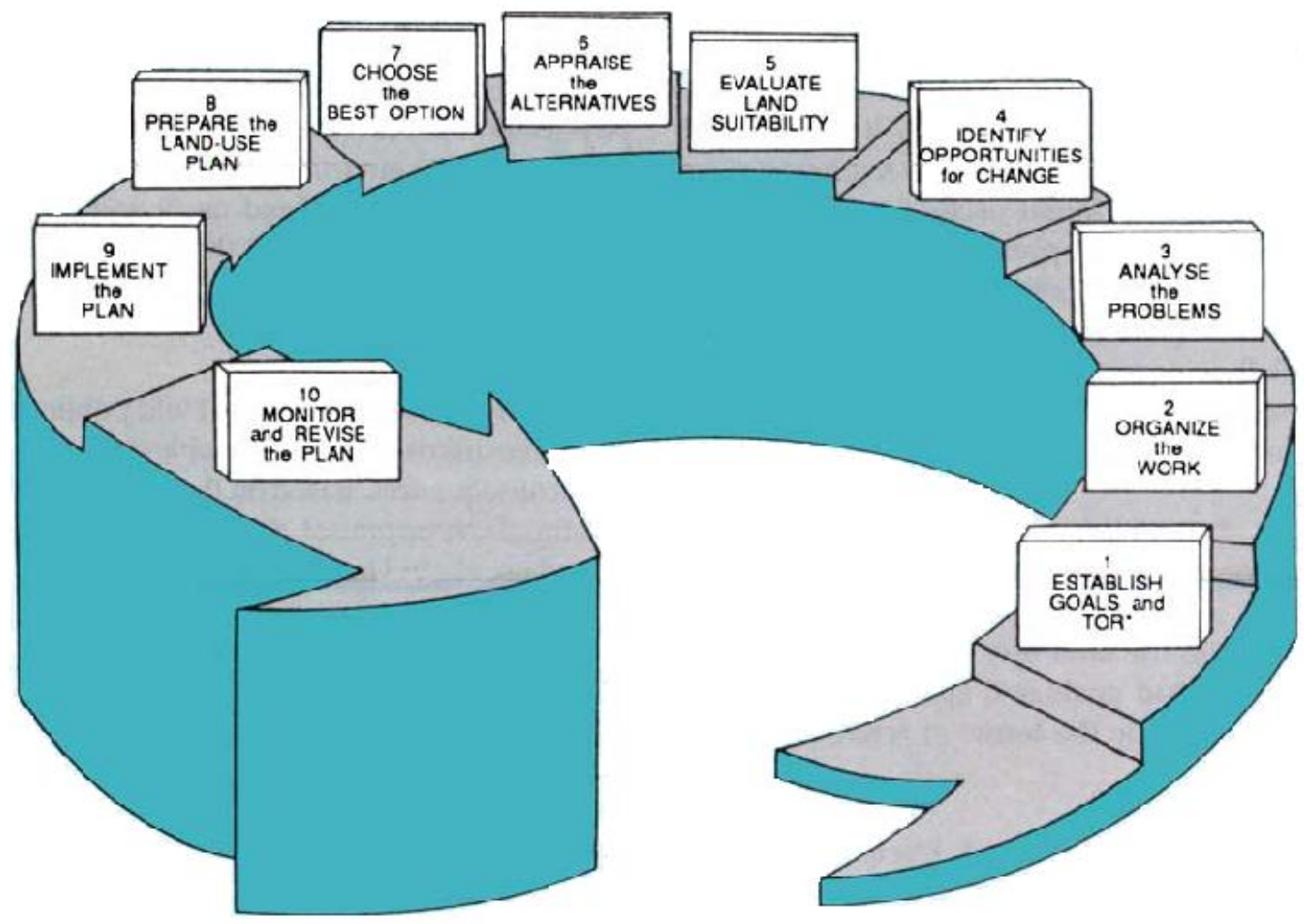

Fig.3.1 Steps in land use planning

Source: FAO 1993, reprinted 1996

FAO (1993) indicated the aims of LUP are to make the best use of limited resources by:

- Assessing the present and future needs and systematically evaluating the land's ability to supply them;

- Identifying and resolving conflicts between competing uses, between the needs of individuals and those of community and between the needs of the present generation and those of future generations;

- Seeking the sustainable options and choosing those that best identified needs;

- Planning to bring about desired changes;

- Learning from experience. 
According to the fig.3.1, the contents of land evaluation are described from $5^{\text {th }}$ step to $7^{\text {th }}$ step. Land evaluation is mainly the analysis of data about land, containing: soils, climate, vegetation, etc, in term of realistic alternatives for improving the use of land. It is focused upon the land itself, its properties, functions and potentials (FAO, 2007). The primary aim of land evaluation is to determine the suitability of land for alternative, actual or potential land uses which are relevant to the area under consideration (Loi, 2008). Based on the results of land evaluation, some land use scenarios for the future are proposed and implemented in specific areas. However, some conflicts between different stakeholders are not clearly solved in the LUP process, so the decision-makers need to trade-off between different conflicting goals. According to Huy (2009: p10) FAO's Guidelines for Land Use Planning states that three different levels at which LUP can be applied are national, district and local. These different levels of LUP are relevant to the levels of government at which decisions about land use are taken.

A technique used to solve these conflicts is the Multi-Criteria Evaluation (MCE) emerged during 1970's (Trung, 2006: p35). This method includes 6 components: (1) a goal; (2) the decision maker; (3) evaluation criteria; (4) decision alternatives; (5) a set of uncontrollable variables and (6) a set of outcomes. According to Nguyen Hieu Trung (2006) the integrating FAO approach with MCE for Land Use Planning includes 6 steps: (1) biophysical land evaluation; (2) socio-economic assessment; (3) environmental assessment; (4) standardization; (5) calculation of suitability scores; (6) scenarios analysis.

The advantages of the FAO-MCE approach are allowed to integrate between biophysical land evaluation, socio-economic and environmental assessment. Scenarios analysis can help decision-makers trade-off different goals in the long term sustainable development. However, the drawbacks of FAO-MCE approach are less realistic with large land mapping units (LMUs) and the possibly subjective justification and standardization of chosen criteria (Trung, 2006: p33).

\subsubsection{Participatory Land Use Planning (PLUP)}

People's participation in rural development was formulated in the mid-1970s. Participation of rural people in the institutions that govern their lives is a basic human right (UN, 2009: 
p10). The Food and Agriculture Organization launched the people's participation programme (PPP), then PPP has implemented pilot projects throughout the developing world in an attempt to test and develop an operational method of people's participation for incorporation in larger rural development schemes (FAO, 1990). According to Nguyen Hieu Trung (2006: p97), in the recent year, Participatory Land Use Planning (PLUP) has gained international recognition as an important tool for achieving sustainable development and sustainable resource management by local communities. Based on this approach, several studies were carried out in various regions, such as: China, Thailand, India and Sri-Lanka (Albecht et al., 1996). There were also some case studies carried out in Vietnam, Lao, Cambodia, and Thailand (Trung et al., 2004).

The PLUP approach focuses on the capacities and needs of local people, so that sustainable land resources management can be achieved when the local people participate in management. The approach is promising in improving farmer awareness of environmental problems and solutions, as well as in linking local and scientific knowledge (Fagerström et al., 2003). According to Fagerström (2003), there are three steps in this approach, including: (1) researchers learning about local conditions; (2) the analyses of land use by local farmers; (3) the feedback of farmer-researcher in different land use scenarios and potential effects on erosion and the household economy. Accordingly, a PLUP workshop is organized in a village to investigate the land use problems, their causes, effects and possible solutions. The workshop confirms the integrating scientific and local knowledge to concrete options for sustainable land use that fit to local realities and aspirations (Hessel et al., 2009). PLUP tries to indentify land use options that are accepted by stakeholders and satisfy the needs of all parties involved. Consequently, land users have to agree with the purposes of LUP, so they have to realize their responsibilities for sustainable land use and development.

In brief, PLUP uses the bottom - up approach to achieve the purposes of land use for the future. The land use options are contributed from each land user, so PLUP is very useful to apply in small areas like village, commune (Trung, 2006: p82). In contrast, the difficulties of PLUP are to conduct in a large area and abilities of local people involved. 


\subsubsection{Land Use Planning and Analysis System (LUPAS)}

The LUPAS methodology was developed under the systems research network for Ecoregional Land Use Planning in Tropical Asia (SysNet) project (1996-2000). The SysNet is a system research network in South and South-East Asia, established for development and the evaluation of methodologies to enhance strategic land use policies (Trung, 2006: P5).

Actually, LUPAS has three main methodological components, including: (1) land evaluation; (2) scenario construction; and (3) multiple goal linear programming (Laborte et al., 2002). Similar to other methodologies, land evaluation and scenario are the basic components of LUP basing on the biophysical, socio-economic conditions in the specific area. In addition, multiple goal linear programming is the computerized component assisting planners, experts, and authority agents in setting up the targets for the long-term development. LUPAS is a computerized decision support system based on the interactive multiple goal linear programming approach. It can be applied for scenario analysis of a complex problem like conflicts in land use (Roetter et al., 2005).

Furthermore, LUPAS consists of four main parts, including: (1) resource balance and land evaluation; (2) yield estimation; (3) input-output estimation; (4) interaction multiple goal linear programming (Fig.3.2). It can be used to point out the constraints of development deriving from the resources available, such as: labour resource, capital limitation, and natural resources. Based on the development targets, goal restrictions are formed in LUPAS, such as: minimum rice production for food security. Based on these, different land use scenarios can be analyzed and optional land use can be selected to implement in specific area. However, when development constraints and goals restrictions are changed, the land use scenarios are changed accordingly. The LUPAS approach is still a top-down approach, so participation of stakeholders is limited, even though they are taken part in setting development constraints and goal restrictions. Estimation of input/output depends on the secondary data. Thus, the precise results of models depend on government policy and ecological situations (Trung, 2006: p64). 


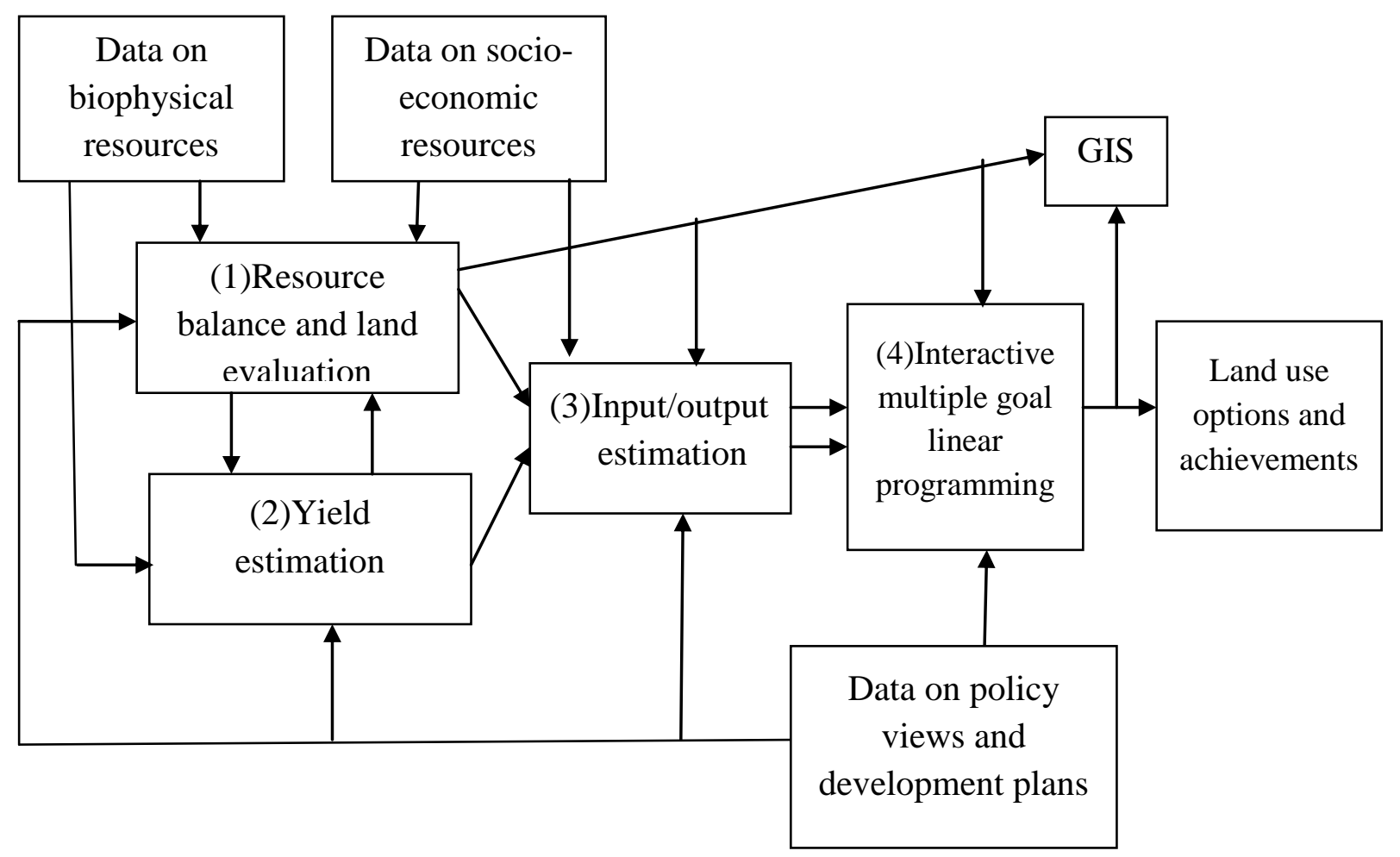

Fig.3.2 Components of LUPAS

Source: Roetter et al., 2000

\subsection{Land Use Planning and sustainable development}

Sustainable development is basically defined as: "Sustainable development is development that meets the needs of the present without compromising the ability of future generations to meet their own needs" (WCED, 1987: p43). According to FAO "Sustainable development is the handling and conservation of natural resources and the orientation of technical and institutional change so as to ensure the continuous satisfaction of human needs" (FAO, 1989 cited by Golley and Bellot (1999)). Thus, the goals of economic and social development must be defined in sustainable development. In addition, environmental condition must also not be compromised for both present and future generations, a concern that must logically be extended to equity within each generation (Silberstein \& Maser, 2003: p101-103). The satisfaction of human needs and aspirations is one of the major objectives of sustainable development. The basic needs of all, including: 
food, clothing, shelter, and jobs are met gradually and the standard of living is increasingly improved between different generations (UN, 1987: p2-3). Therefore, sustainable development is based on three vital pillars, including: social, economic and environmental dimensions (Counsell \& Haughton, 2006; Hietel et al., 2005). Three major sustainable development goals, as follows: environmental protection, social and intergenerational equity, and economic development can balance in the sustainability literature (Conroy \& Berke, 2004). However, many already existing conflicts need to be eliminated because of the pursuit and balancing of the three main goals of economic development, environmental protection and equity, social justice (Cambell, 1996). The aim of Land Use Planning is to concretize development policies into long-term land use in different scales. Not only does this process look at environmental issue, but it also draws attention on social and economic development (Counsell \& Haughton, 2006).

Land Use Planning is a method to manage land resources sustainably. The adaptation of management methods in order to optimize land capabilities is one of the key points to ensure sustainable land use in the long term (Golley \& Bellot, 1999; Puginier, 2002: p129). Especially, in agriculture, the vital role of land is rather meaningful than others because of a great impact on natural resources. LUP has also closely related to the land consolidation. It is seen as a tool to improve working conditions in agriculture and the living conditions of people living in rural areas (Pasakarrnis \& Maliene, 2010). Industrialization and urbanization are two major driving forces contributing to land-use change (Long et al., 2007). Moreover, LUP has to propose the way to protect water resources and preserve the natural areas without the violating people. When the proper land uses are proposed by LUP, the less ecological conflict is created, the more sustainable situation becomes (Jurgens, 1993).

Community and local people's participation is one of the pillars of LUP and sustainable development. Community has the ability to participate in the management of natural resources, so some conflicts on land use can be basically reconciled by communal benefits. The contribution of local people to land use or development scenarios is crucial for sustainability. Additionally, local people contribute to building and implementing the development policies. The planning is an efficient means of informing and impacting local policy related to sustainable community development (Cecilia et al., 2010). Furthermore, one of the LUP's aims is to increase the income of land users through the land use 
scenarios in the future. The better quality of life at present and for the future generations is ensured that is the heart of sustainable development (DETR, 2000).

Furthermore, LUP plays a vital role in natural preservation and restoration as well. Normally, by constructing a fence or generating the rule, some heritages and relics are protected without the invasion of human activities. Planning is also an approach to preserve cultural heritages and relics by proposing a vision of development and integrating with future development of other functions (Jelier et al., 2005). Thus, integration between LUP and cultural heritage, relic conservation is significantly meaningful for sustainable development because it creates a bridge between the past, recent and future events. In addition, the buffer zones of urban areas planned in LUP are meaningful as well to alleviate the noise pollution and contribute to the beautiful design of landscape. The standard of living is, therefore, improved through LUP.

In addition, LUP is concerned with different functions regarding to sustainable development as landscape multifunctionality. It is defined as follows: "Multifunctionality provides us with a way of understanding change and delivering jointed-up policy at the landscape scale, where its core property of interactivity can be harnessed in ways that produce qualities valued by people" (Selman, 2009). Some features of multifunctionality include: the integration of different land use goals, the relationship between rural, urban and urban fringe, reconnection between social, economic and environmental development. These features are mostly mentioned in the contents of LUP. Social, spatial, environmental, economic development and LUP cannot be done in isolation owing to the relationships between them (Weng, 2010: p330).

The relationship between LUP and sustainable development has to continuously exist in both the present and the future because of the continuous increase of the people's needs and the meet of the needs for both present and generations to come. The integration of the soft $^{2}$ and hard systems ${ }^{3}$ that will be established in LUP will enable stakeholders to manage their natural resources in a sustainable way (Nidumolu et al., 2006). LUP will also ensure the long-term quality of the land for human use, the prevention or resolution of social

\footnotetext{
${ }^{2}$ Soft system: assessment, evaluation, contribution

${ }^{3}$ Hard system: process, framework
} 
conflicts related to land use, and the conservation of ecosystems of high biodiversity value (FAO, 1995).

\subsection{Overview of Land Use Planning in Vietnam}

Land Use Planning (LUP) and plans in Vietnam is one of the 13 contents of State management on land (Article 6, Land law 2003) (Anonymous, 2003). It is an administrative process to manage land resources. LUP divides and allocates land for specific purposes and development among different sectors. Not only is it the spatial plan in the country, but there are also urban development plans, agriculture development plans, forest planning, and many more. However, the Land Use Planning is, in theory, the overriding spatial plan that covers all land and is also the legal basis for any types of land use. It is developed every 10 years (planning) and 5 years (plan) for all administrative levels as well as for high-tech zones and special economic zones (Anonymous, 2003; SEMLA, 2009). There were two main periods of development regarding to LUP, as flows:

In the period of 1975 - 1986, all of Vietnam had a centrally planned economy decreed by five-year plans with production targets (Trung, 2006: p1-2). The planning system basically followed the economic system when often government interfered arbitrarily in the production and distribution process. Land Use Planning followed the Soviet socialist-style model of a centrally planned economy. Under this system, the resources were allocated by the state through its command directive system. The means of production belonged to public ownership. The operation of the centralized planning model was described in simple form, as follows: the state economic units were set up in accordance with Soviet managerial style in order to produce a certain product (or a group of products). The production inputs and outputs were supplied and received directly by the state without analyzing the economic effectiveness and efficiency based on real demand and purchasing power from the society. In this model, the private sector was abolished and there was no opportunity for foreign capital to invest (Quang, 2003: p4-6). Therefore, LUP in this period showed the bold characteristics of bureaucratic and subsidized mechanism and met the needs of the centrally planned economy without the demands of land users.

By 1986, the $6^{\text {th }}$ Vietnam Party Congress officially launched the socioeconomic reform 
(Doi Moi) recognizing the multi-sectoral market economy and creating the legal framework for private sector development. In the physical planning area, despite continuing with the old method of central command planning (in the form of master and detailed plans), the physical planning system was undergoing certain changes, in which the plans were less rigid and took into account market factors. The current Master Plan ${ }^{4}$ was considered as a wider spectrum of market elements, such as: the plurality of development actors, the introduction of a private land use right, the recognition of individual trade (i.e., private shop-houses) and the opening to foreign capital (i.e., industrial zones) (Quang, 2003: p9-11). To improve the quality of LUP in recent years, it has been synchronized with the overall socio-economic development planning and the detailed spatial planning for urban and rural residential areas. Notably, Land Use Planning has been tuning gradually with the market that is development in Vietnam (Vo \& Trung, 2007). Thus, the efficiency of land use and demands of land users for land are emerged continuously in LUP.

Recently, LUP in Vietnam has been carried out at 4 levels (Fig.3.3), including: national, province, district and commune (Decree No 69, 2009).

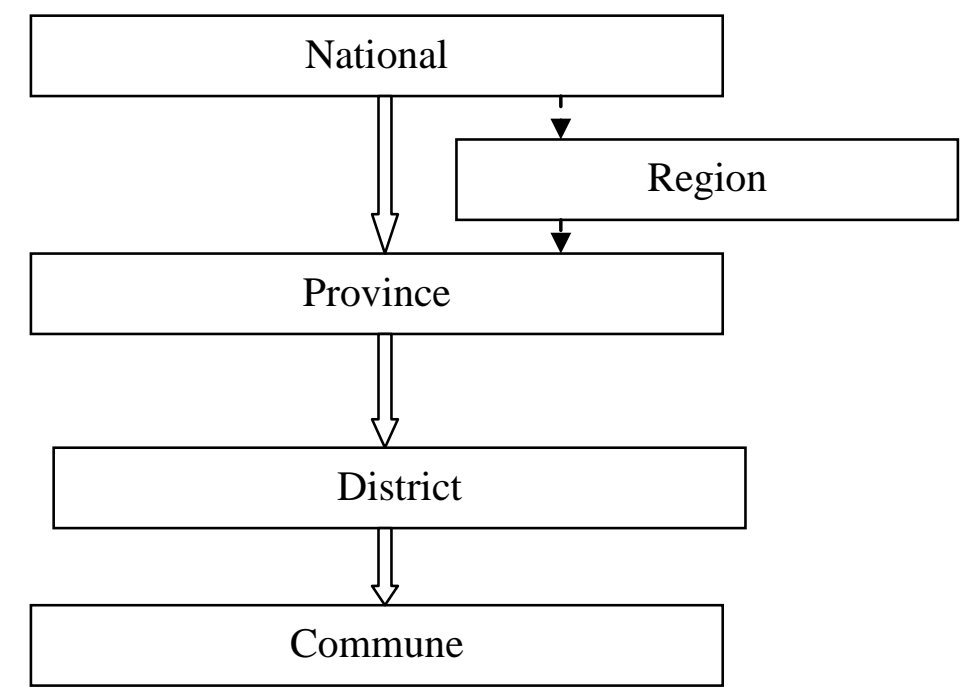

Fig.3.3 Levels of LUP in Vietnam ; Source: Decree No 69 (2009)

Thus, it can be said that LUP has been fitted to the administrative hierarchy in Vietnam as a tool to manage and use land resources efficiently. Besides, to concretize LUP in different scales, the Vietnam Ministry of Natural Resources and Environment (MoNRE)

\footnotetext{
${ }^{4}$ Social-economic development planning
} 
promulgated the Circular No 19 dated 02/11/2009 that amended the Circular No 30/2004 on detailed provisions on land use planning. Seven steps (fig.3.4) of LUP in each level are regulated (Circular No 19, 2009).

According to Huyen (1993: p4-7), the future of LUP strategies will have to consider the population density ${ }^{5}$ of between the most populated and least populated areas which is currently different about 17 times (GSO, 2010). Therefore, future LUP may have to seriously consider redistribution and resettlement of the population covering the entire country, not just in selected areas. The following figure shows the key factors that influence land use planning in Vietnam.

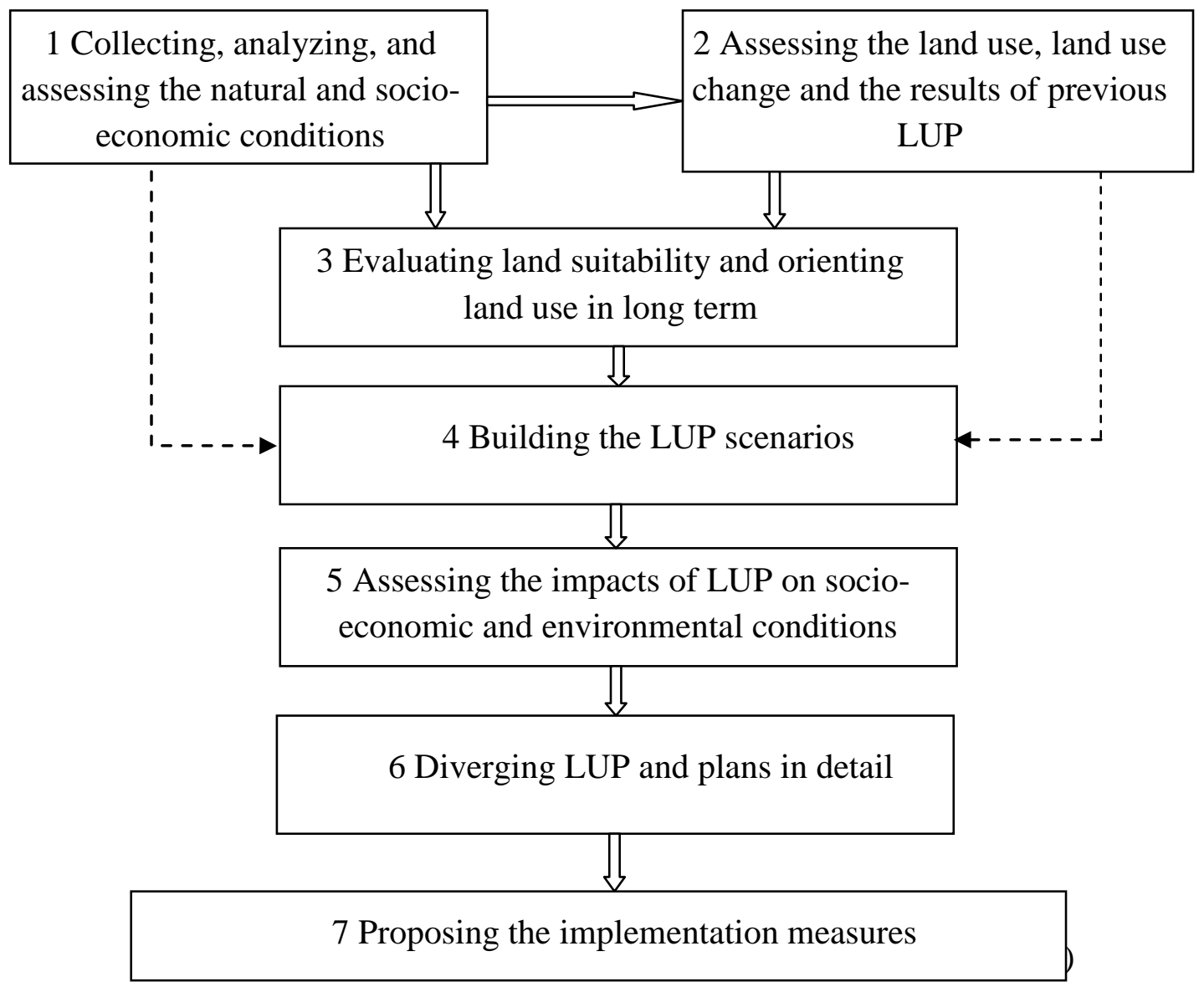

Fig.3.4 LUP process in Vietnam; Source: Circular No 19 (2009)

\footnotetext{
${ }^{5}$ Person per $\mathrm{km}^{2}$
} 


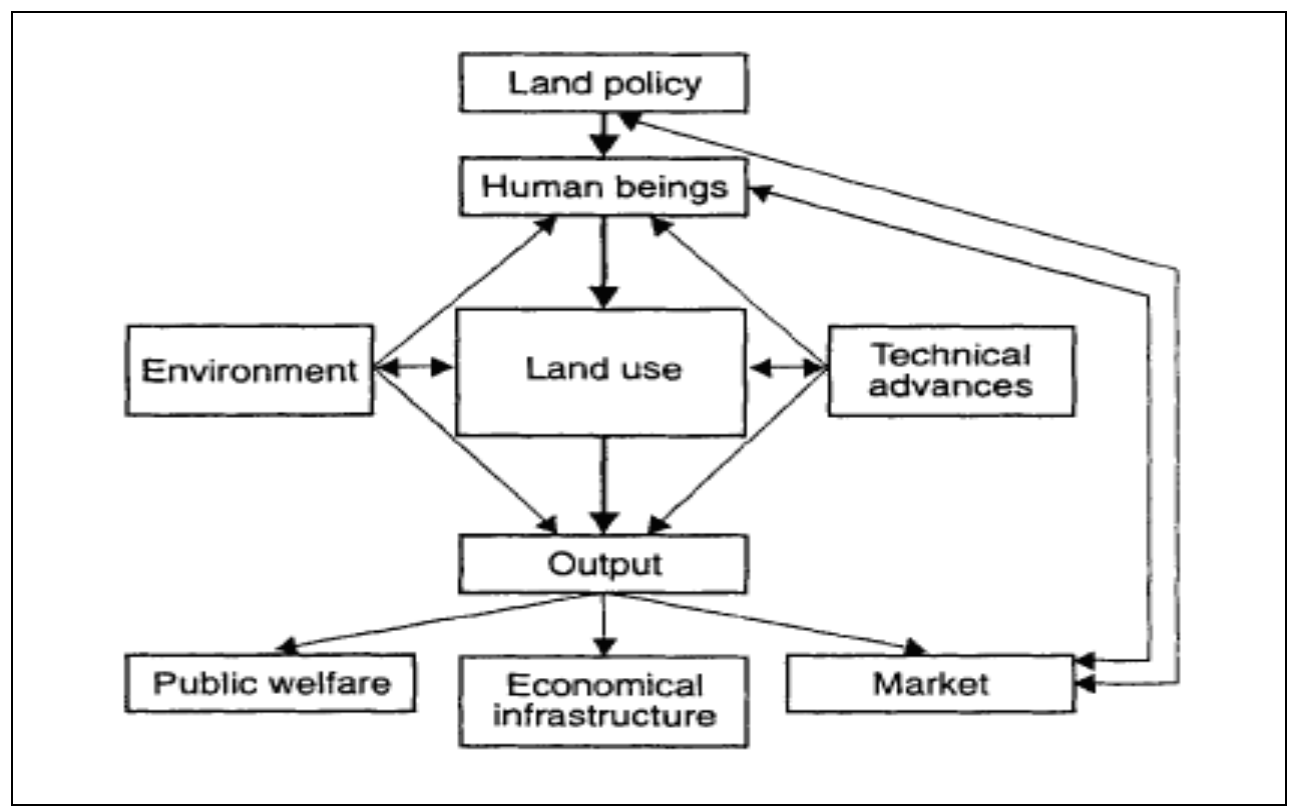

Fig.3.5 Key factors influencing LUP in Vietnam; Source: Huyen (1993)

In addition to the change in economy in Vietnam, environmental fluctuations challenge development and LUP. To deal with these challenges and with the help of the Vietnam Sweden Program on the Strengthening Environmental Management and Land Administration (SEMLA), some pilots of Land Use Planning with integrated environmental factors were carried out in some provinces. A comprehensive report was produced by SEMLA that outlined the current framework and context for LUP in Vietnam and identifies drawbacks and issues, as follows (SEMLA, 2009):

- poorly integrated planning (with other sectors);

- $\quad$ poor quality baseline data/mapping;

- complex instructions which are difficult to follow;

- weakness of planning expertise (lack of capacity);

- inflexibility of plans (difficult to change);

- lack of unified LUP strategy;

- conflicting values and interests;

- weak environmental planning;

- lack of community consultation. 
Lessons learnt: Environmental integration (SEMLA, 2009)

- Integration of environmental aspects has been done in all pilots, to a varying degree and using different methods.

- It is easy to describe current environmental problems, and hard to enforce or implement the environmental recommendations.

- Difficulties encountered include: lack of environmental data, lack of experience in predicting environmental impacts, weak cooperation among agencies, overlaps of different sector plans.

- The level of detail in the environmental assessment of LUP is difficult to determine:

Make it too general and it is not useful.

Make it too detailed and it resembles an Environmental Impact Assessment (EIA) for individual projects.

- The SEMLA integrated model has proven to be useful, especially in defining the LUP organization arrangements, environmental context and trends analysis and public participation.

- Significant improvements can be seen when it comes to evaluating environmental issues that are concerning land use and also impact assessments of LUP.

- Strategic Environmental Assessment (SEA) as a stand-alone process is suitable for large development planning with a multitude of stakeholders and complex environmental implications, either for large areas (regions, provinces) or where major changes are planned for, and not for smaller planning and plans.

- The most effective use of SEA is when elements of SEA (public participation, alternatives development and environmental assessment) are made an integrated part of the LUP process, and not as a parallel process resulting in duplications and weak linkages.

Application of FAO approach, PLUP and LUPAS in Vietnam:

According to LUP process and LUP policy, the FAO approach for LUP is selected as a 
starting point and integrated in different LUP steps in Vietnam (Trung, 2006: p4). Basically, 10 steps of FAO approach and guidelines for LUP are applied specifically in 7 steps of LUP in Vietnam. Nguyen Hieu Trung (2006: p81) stated that the LUP approach is the most popular one in Vietnam. This approach and guidelines are used widely in land valuation to determine land suitability for different land use types in the future (step $3^{\text {th }}$ of LUP process fig.3.4). Besides, the integration of biophysical land evaluation with socioeconomic and environmental appraisal is also observed. It is able to analyze the trade-offs between development targets by analyzing different scenarios. Finally, plan, implement plan and monitor or revise the plan are applied in step $6^{\text {th }}, 7^{\text {th }}$ of the LUP process. Therefore, FAO approach and guidelines for LUP are useful and applied widely in different LUP levels in Vietnam.

Participatory Land Use Planning (PLUP) is bottom - up approach to apply in LUP. The domination of this approach is the vital role of local people in making LUP to achieve the balance development in society. Actually, this approach was applied in Vietnam in 2000's. Indeed, in 2003 PLUP was undertaken in two villages of the Mekong Delta coastal area (Huy, 2009: p38). According to Nguyen Hieu Trung (2006: p81), PLUP is not widely used in Vietnam, but it is gaining attention from the local people in the LUP process. The advantage of this approach is that it can help to reduce the land-use conflicts by taking into account the farmers' requirements. Thus, this method is only used in the lowest level (commune level) that needs to consult from local people in Vietnam.

LUPAS is aimed at optimizing the use of resources. Through the application of LUPAS, the government's development goals are evaluated on their feasibility. Actually, LUPAS was recognized and used in Vietnam in 2000's. Specifically, it was applied in building LUP in Baccan Province and Cantho Province in 2002 and 2003. The results proved that it is suitable for province level (Trung, 2006: p82; Yen et al., 2002). However, it is not used widely in Vietnam. In particular, the multiple goal linear programming is not popular for planners, authorities in Vietnam. Therefore, the application of this method in LUP process in Vietnam is still limited.

In conclusion, in association with the changes of economy towards market-oriented, LUP 
in Vietnam also has changed gradually to supply land resource for development and sustainable development, in particular, to meet the needs of land users (household). However, LUP is obviously an open field needs to be approached by different methods which can help to find the best way for LUP in Vietnam. The integration of environmental afactors into LUP has actually germinated in Vietnam by the help of SEMLA. However, the integration was not in the process of LUP, even though it was carried out as some experiments in some provinces. Moreover, the integration was estimated as a referent document for planners to conduct in other plots in Vietnam. Furthermore, an economic analysis of the integration was not actually conducted in the plots. These limitations need to be studied in further research.

\subsection{Correlation between LUP and socio-economic development in Maichau District, Hoabinh Province, Vietnam}

The following analysis is based in interview data on the importance of LUP on development in the case study district as well as on a statistical analysis of actual land use change in comparison to the directives in LUP 2000.

\subsubsection{Conceptual frame work}

\subsubsection{Statistical data}

To determine and analyze correlation between LUP made in 2000 and actual socioeconomic development from 2001 to 2010 in Maichau District, secondary data needs to be collected, including:

- The results of LUP made in the year of 2000 for the period of 10 years development from 2001 to 2010 were collected at the Department of Natural Resources Management at the district and province level.

- Based on the land use pattern in the year 2010, the implementation of LUP from 2001 to 2010 is judged. Also, it was investigated at the Department of Natural Resources Management in different scales. 
- Economic development in such period from 2001 to 2010 including agriculture, non-agriculture, etc. especially agriculture was also collected at the different departments in the research area.

- Actual social and environmental conditions from 2001 to 2010 stored regularly at the Statistical Department were used to compare with the results of LUP.

\subsubsection{Interview}

Interview and observation methods were used to gather information regarding to the making and contribution of LUP to socio-economic development in the selected area. The interviewees were authorities and natural resources management officials at the different communes who participated in the making LUP in 2000 and implemented this LUP from 2001 to 2010 in their locations. Basically, participants have to clarify the contribution of LUP to socio-economic development of their communes.

The aim of interviewing the authorities at different communes in the district is to collect their judgments of economic, social and infrastructure development in their location, as they have connection with LUP made in 2000. Consequently, their judgment of LUP's contributions is one of the basic assessments to address the correlation.

Questionnaire was focused on:

- Process to make LUP in the year 2000

- Contribution of LUP to socio-economic development.

- Effect of LUP on environmental development.

The framework is shown in the fig.3.6 


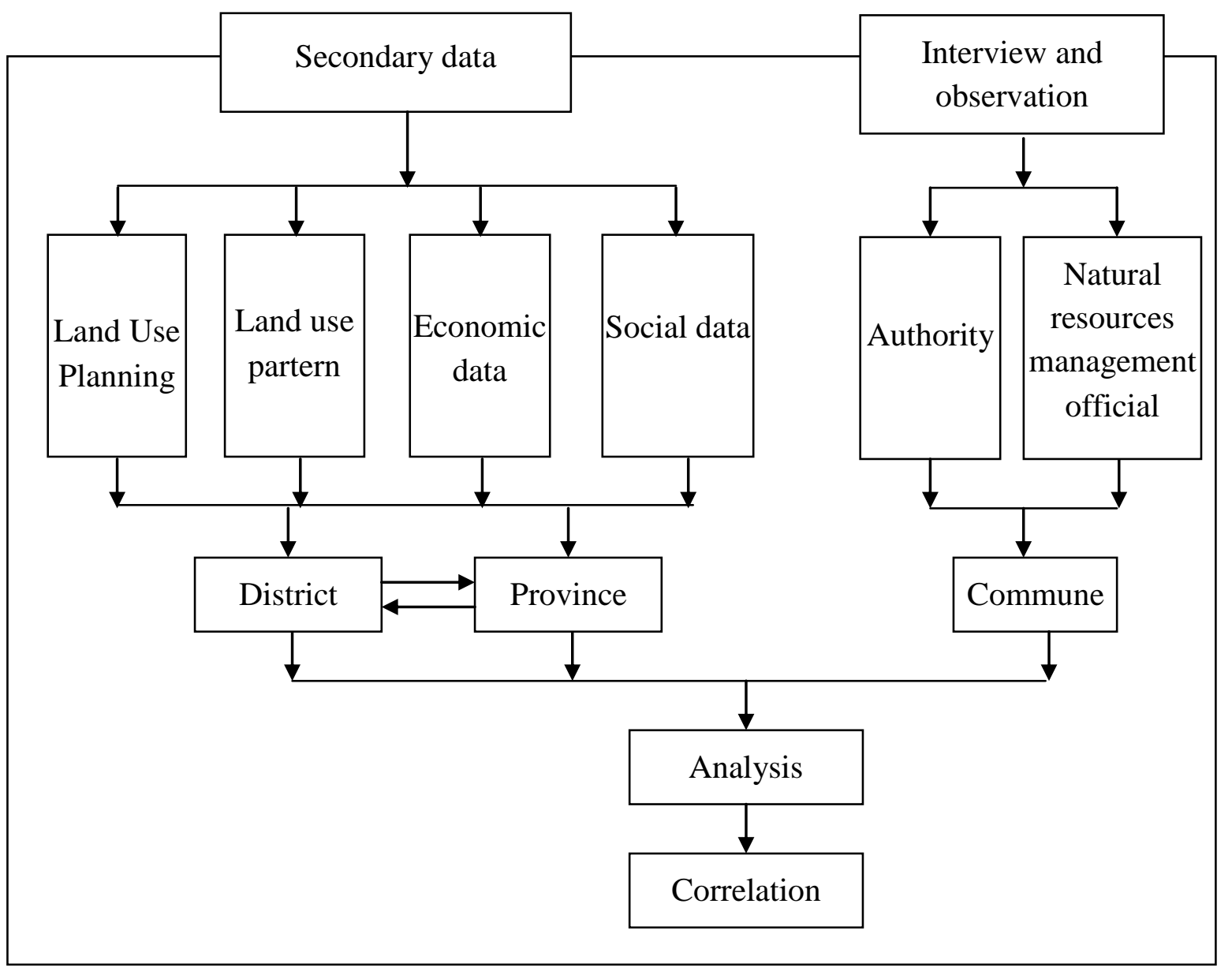

Fig.3.6 Conceptual framework to determine the correlation

Accordingly, the combination between secondary data and primary data plays the vital role in order to determine the correlation. SPSS was used to analyze the data and linear regression indicated the correlation between LUP and socio-economic development.

\subsubsection{The results of LUP in Maichau District, Hoabinh Province, Vietnam}

A summary how LUP 2000 envisioned the changes to the main land use types are shown in fig.3.7. Several land use types should increase gradually. E.g., agricultural land was to rise by 347 ha from 2001 to 2005 and 399 ha from 2006 to 2010, forest land was to increase by 3,281 ha from 2001 to 2005 and 4,121 ha from 2006 to 2010, non-agricultural land also was to rise by 128 ha from 2001 to 2005 and 100 ha from 2006 to 2010 . On the contrary, unused land was planed to decrease dramatically by 3,757 ha from 2001 to 2005 and 4,621 ha from 2006 to 2010. 


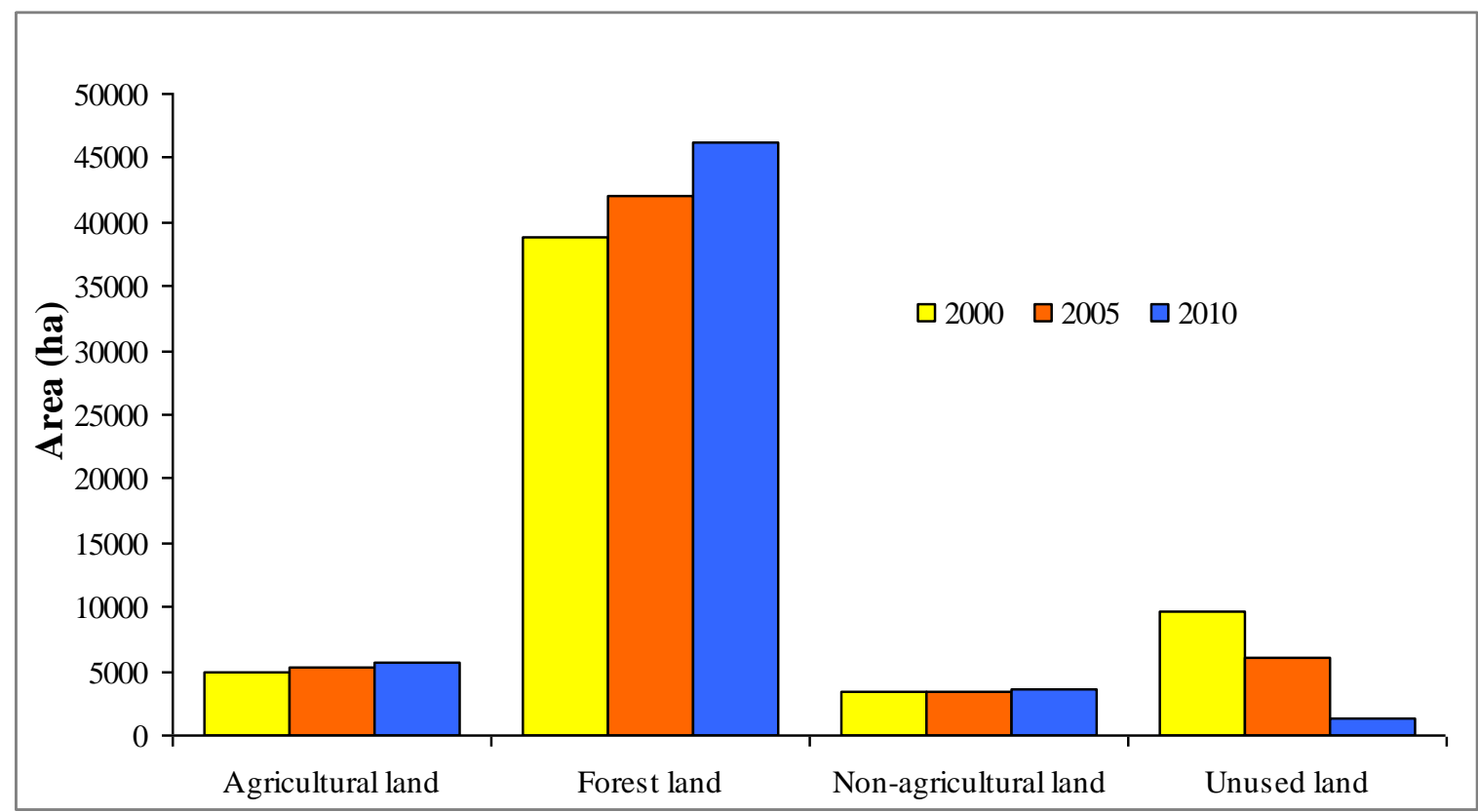

Fig.3.7 Comparison between different land use types in LUP in Maichau District; Source: Anonymous (2001)

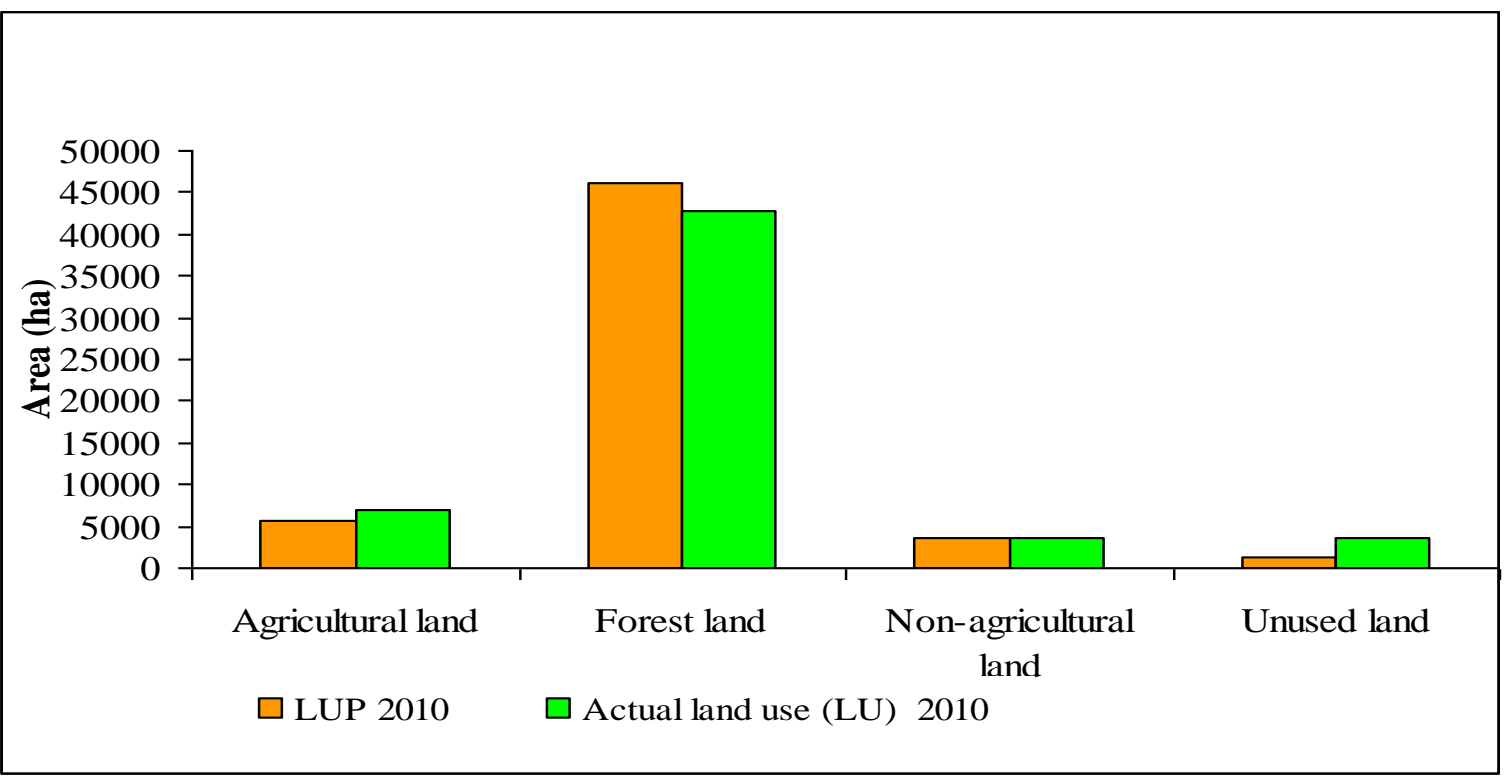

Fig.3.8 Comparison between area of land uses in LUP and area of actual land use in 2010 in Maichau District; $\quad$ Source: Anonymous (2001, 2010d)

The data in fig.3.8 shows the comparison between area of land uses in LUP 2000 and area of actual land uses 2010. There was a difference between land use types in LUP and actual land use in 2010. 
Table 3.1 Results of land use planning implementation from 2000 - 2010

\begin{tabular}{|c|c|c|c|c|}
\hline Land classification & $\begin{array}{l}\text { LUP } 2010 \\
\text { (ha) }\end{array}$ & $\begin{array}{l}\text { Actual land use } \\
\text { (LU) } 2010 \text { (ha) }\end{array}$ & $\begin{array}{l}\text { Difference } \\
\text { (ha) }\end{array}$ & $\begin{array}{c}\text { Comparison } \\
(\%)\end{array}$ \\
\hline 1 Agricultural land & $5,749.50$ & $6,853.39$ & $1,103.89$ & 119.20 \\
\hline $\begin{array}{l}\text { 1.1 Land for cultivation of } \\
\text { annual crops }\end{array}$ & $4,393.93$ & $6,421.54$ & $2,027.61$ & 146.15 \\
\hline Rice & $1,265.89$ & $1,244.51$ & -21.38 & 98.31 \\
\hline Others & $3,128.04$ & $5,177.03$ & $2,048.99$ & 165.50 \\
\hline $\begin{array}{l}\text { 1.2 Land for cultivation of } \\
\text { perennial crops }\end{array}$ & $1,355.57$ & 431.85 & -923.72 & 31.86 \\
\hline 2 Forest land & $46,176.61$ & $42,833.77$ & $-3,342.84$ & 92.76 \\
\hline 2.1 Land for production forest & $27,798.23$ & $14,384.61$ & $-13,413.62$ & 51.75 \\
\hline 2.2 Land for protection forest & $12,857.08$ & $23,500.97$ & $10,643.89$ & 182.79 \\
\hline $\begin{array}{l}2.3 \text { Land for special-use } \\
\text { forest }\end{array}$ & $5,521.30$ & $4,948.19$ & -573.11 & 89.62 \\
\hline 3 Residential land & 821.42 & 861.08 & 39.66 & 104.83 \\
\hline $\begin{array}{l}4 \text { Land for construction of } \\
\text { offices, public service } \\
\text { delivery institutions }\end{array}$ & 28.59 & 12.68 & -15.91 & 44.35 \\
\hline $\begin{array}{l}5 \text { Land for national security } \\
\text { and defense purposes }\end{array}$ & 26.00 & 7.82 & -18.18 & 30.08 \\
\hline $\begin{array}{l}6 \text { Land for non-agricultural } \\
\text { production and business }\end{array}$ & 27.98 & 28.07 & 0.09 & 100.32 \\
\hline 7 Land for public use & 532.76 & 496.00 & -36.76 & 93.10 \\
\hline $\begin{array}{l}8 \text { Land used for cemeteries } \\
\text { and graveyards }\end{array}$ & 215.01 & 183.91 & -31.10 & 85.54 \\
\hline $\begin{array}{l}9 \text { Land with rivers, canals, } \\
\text { streams and specialized water } \\
\text { surface }\end{array}$ & $1,921.71$ & $1,921.71$ & 0.00 & 100.00 \\
\hline 10 Unused land & $1,350.80$ & $3,651.95$ & $2,301.15$ & 270.35 \\
\hline Total area & $56,850.38$ & $56,850.38$ & & \\
\hline
\end{tabular}

Source: LUP in Maichau District 


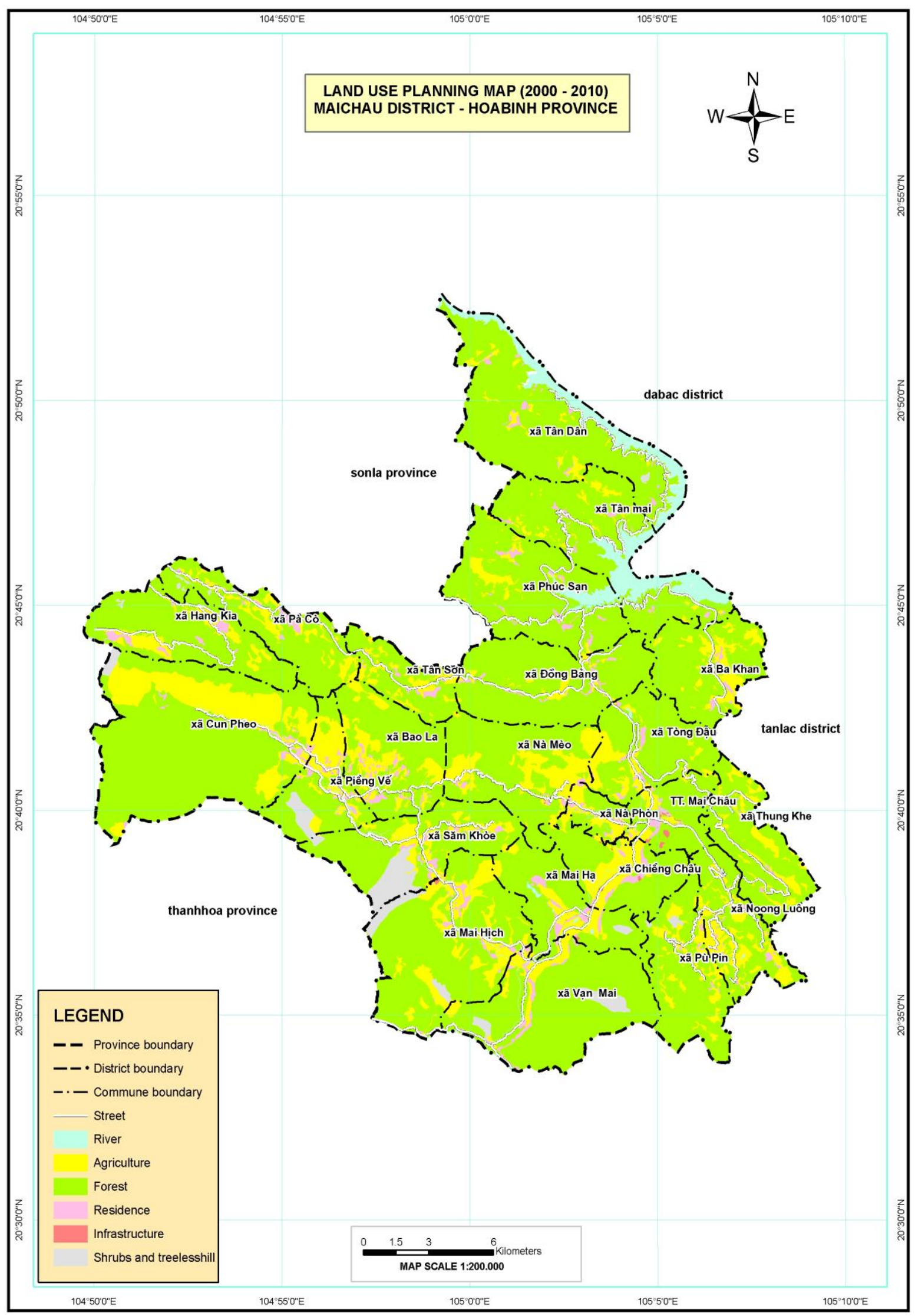

Fig.3.9 LUP map in Maichau District, Hoabinh Province Source: Anonymous, 2001 
The data in table 3.1 demonstrates that actual agricultural land exceeded nearly $20 \%$ in comparison with agricultural land proposed in LUP, especially annual crop land exceeded nearly $46 \%$. However, actual forest land only achieved $93 \%$ of the LUP plan, of which production forest land achieved nearly $52 \%$ and protection forest land reached around 183\% LUP. In the past period (2000-2010), the reforestation in Maichau, focused potentially more on protection than production forest. Moreover, actual residential land obtained nearly 105\% LUP (exceeded 5\%). Land for construction of offices, public service delivery institutions and land for national security and defense purposes only attained roughly $45 \%$ and $30 \%$, respectively. These ratios, therefore, were very low which can be estimated that the purpose of using these types of land was changed in the actual implementation period. Probably, socio-economic background assumptions of LUP 2000 as well as certain detailed planning ideas did not precise match actual development. Land for non-agricultural production and business obtained nearly 100\% LUP, so purposes of LUP and actual socio-economic development were matched together. Notably, unused land in LUP and actual land use were quite different. Indeed, this area in actual land use was about 3,652 ha in comparison with 1,351 ha in LUP, so the difference was about $270 \%$.

To sum up, the changes to the total stock of land use classes tended to develop into the direct that was intended by LUP 2000.

\subsubsection{Correlation between LUP and socio-economic development}

\subsubsection{Correlation between LUP and food production}

The commercial and industrial development in Vietnam is subjected to certain limitations especially in mountainous regions. To ensure food for the local people has been a significant concern of famers and authorities (FAO, 2011: p2). Cuong (2005b: p30) demonstrated that developing agriculture and rural economy to large-scale production would form a basis for economic, political and social stability. Thus, land users should develop and exploit effectively the natural resources in their administrative areas (Jocelyn, 2002: p28). In the period from 2000 to 2010 in Maichau District, total food production increased remarkably due to some reasons, such as: an increase of the crop yields, and 
annual crop area or suitable change of the location of annual crop with higher crop yields. The correlation between annual crop area and self-produced food is shown in the fig.3.10.

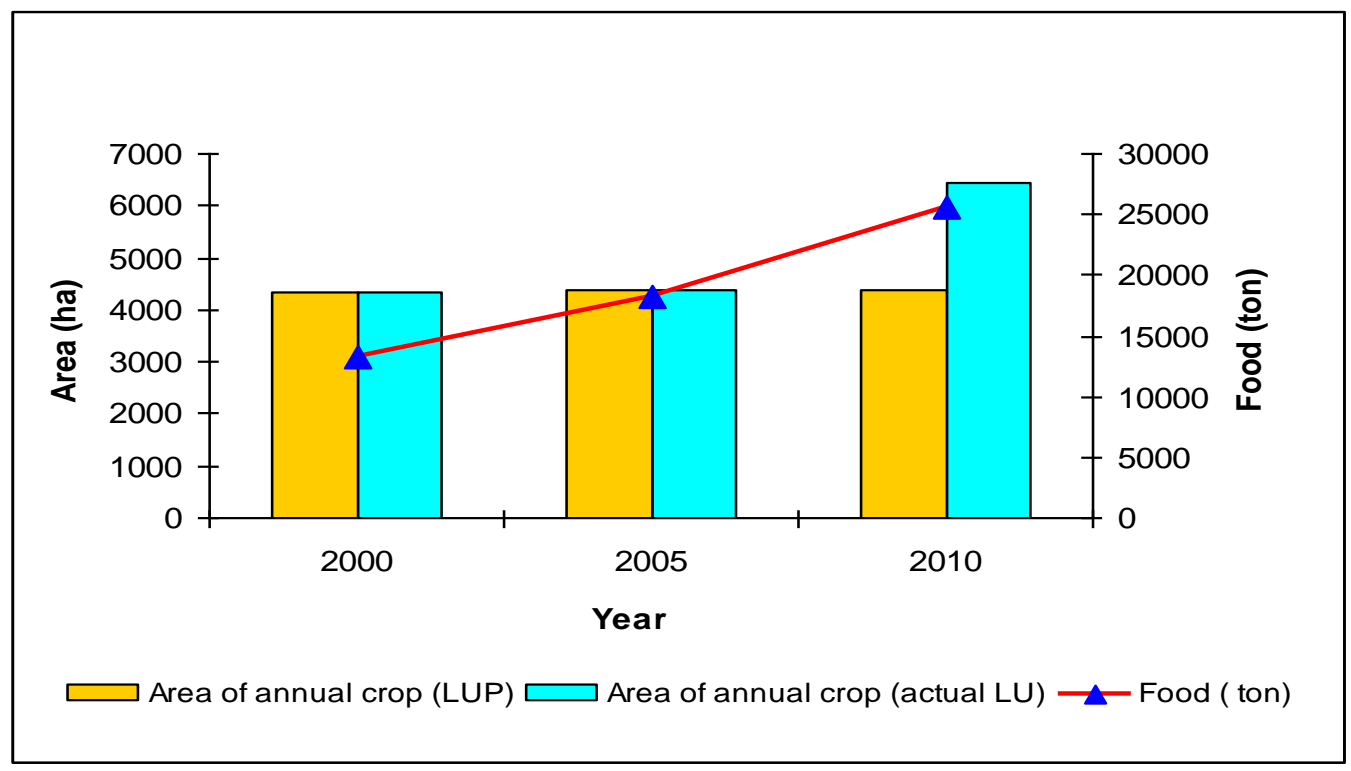

Fig.3.10 Annual crop land and food production (2000-2010)

The data indicates that total food product in Maichau increased gradually from roughly 13,200 tons in 2000 to 25,600 tons in 2010 , while the area of annual crop also rose by nearly 53 ha in LUP and 2,080 ha in actual land use throughout the same period.

\subsubsection{Correlation between LUP and population growth}

To stably develop the society is also one of the main goals of LUP. Trends of population growth and economic development are directly related to the political stability of the government during the particular time in history (Kelly, 2004: p30). The rate of population growth in developing countries is higher than in others, especially in Southwest Asian countries, such as: Vietnam and Indonesia, so the need to extend the residential area has been estimated as higher for LUP at different levels from nation to commune. Additionally, population density controls, one form existing in most LUP, can be expressed in different ways (Evans, 2004: p38). The correlation between LUP and population growth in Maichau District is shown in fig.3.11. 


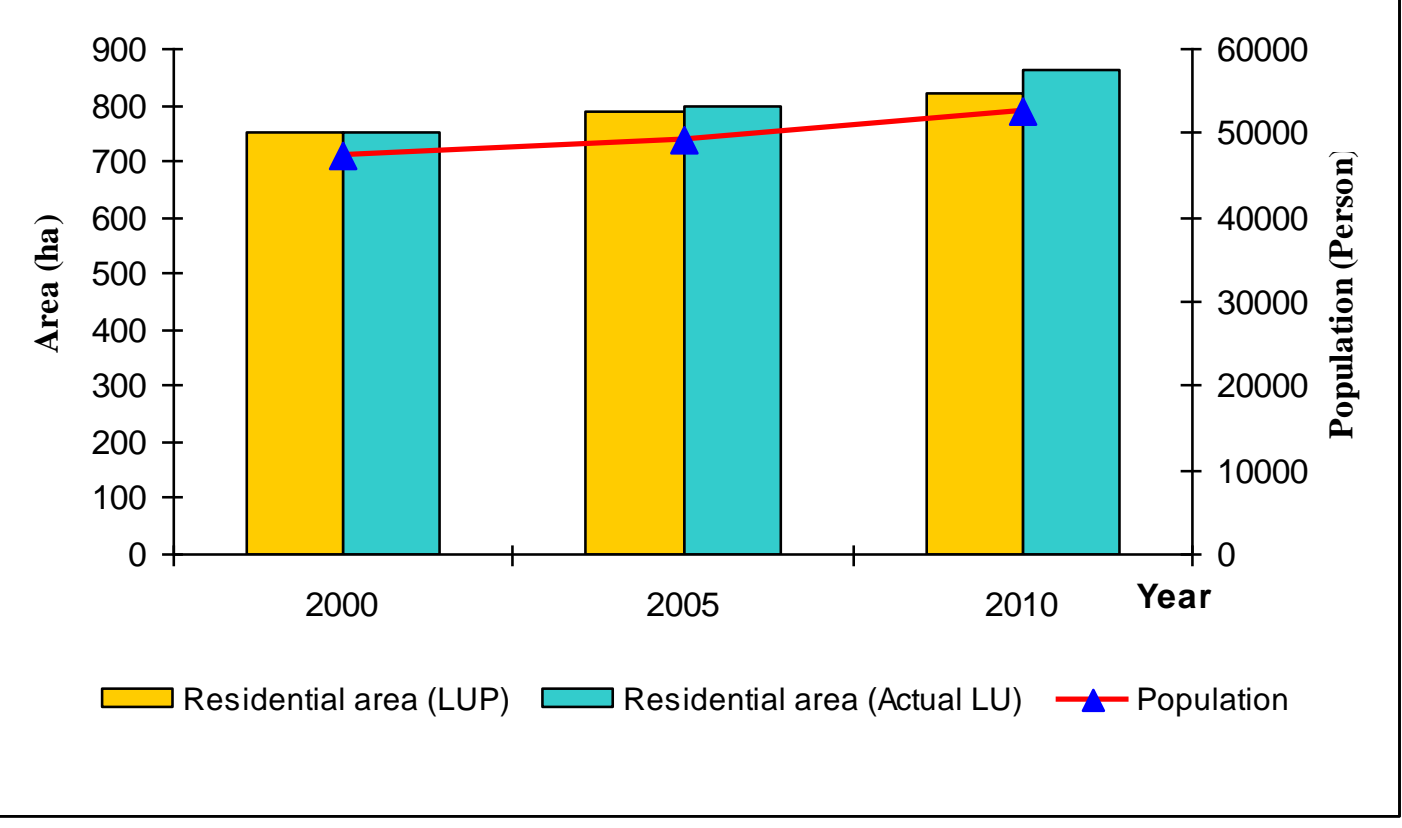

Fig.3.11 Correlation between residential land and population growth in Maichau

The figure indicates that the population of the district increased gradually from around 47,300 people in 2000 to 52,700 people in 2010, with an average population growth of $1.12 \%$ in 10 years (GSO, 2010). While residential land also rose significantly in both LUP and actual Land Use (LU). Indeed, the increases of roughly 70 ha and 110 ha were in LUP and actual LU, respectively. It is obvious that LUP was meant to provide land for population growth in such period.

\subsubsection{Correlation between LUP and industrial development}

Avans (2004: p20-22) demonstrated that the use of land and the location of activities that operate in LUP process possibly control the economic activities towards economic efficiency. The increase or decrease of land for economic activities is merely solved by LUP, it is a unique tool to accommodate land for different purposes throughout the specific period of development. In the first period of industrialization, land is actually significant and appeals to investors. The realization of rural industrialization and modernization demanded that industrial land rise significantly to meet the need of land and contribute to the increase of income from industry for local people (Anonymous, 2001: p52). 


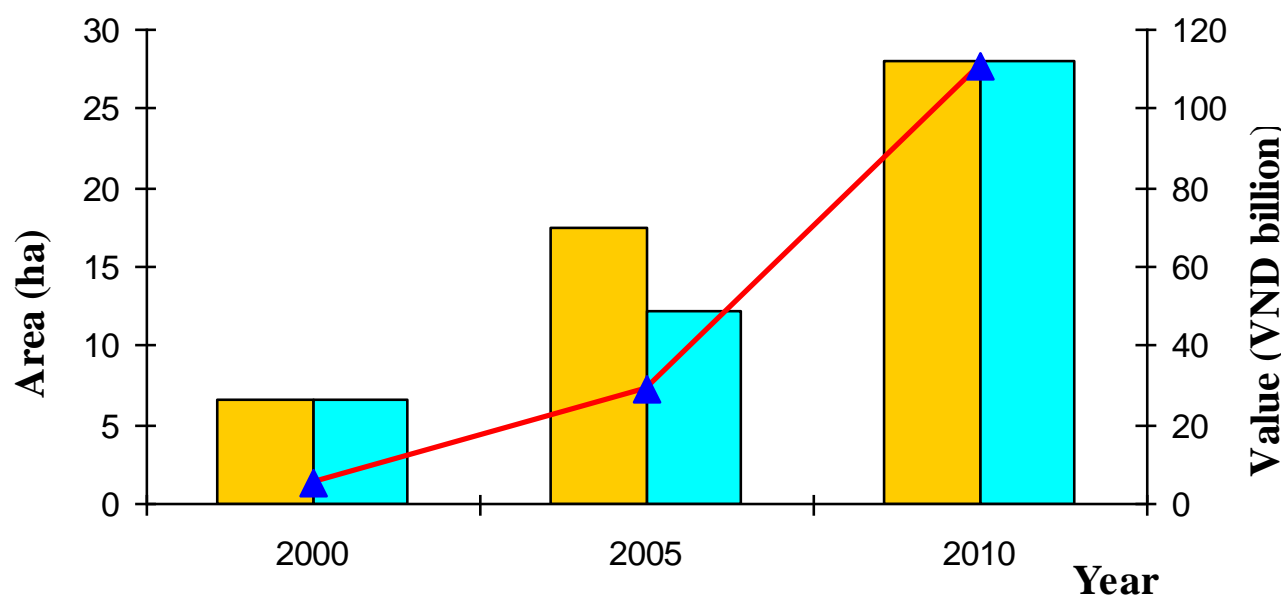

Land for non-agricultural production and business (LUP)

Land for non-agricultural production and business (actual LU)

$\checkmark$ Value of industry

Fig.3.12 Correlation between industrial land and value of industry in Maichau

Fig.3.12 illustrates that land for non-agriculture and business was expanded gradually to support the demand of industrial development in Maichau District. Specifically, industrial land soared by around 21 ha both in LUP and actual LU from 2000 to 2010, an increase of more than 3 times throughout that period. The income from industry also rose dramatically from VND 5.43 billion in 2000 to VND 105.46 billion in 2010, higher by nearly 20 times. It is assumed that the increase of industrial land affected positively the industrial income of the district.

The correlation between Land Use Planning and food production, population and industrial value was synthesized in table 3.2. It shows that total output indicators correlate well with total assigned land use for a suitable land use category. 
Table 3.2 Correlation between LUP and social economic development

\begin{tabular}{llccc}
\hline \multirow{2}{*}{ Dependent variables } & & \multicolumn{2}{c}{ Independent variables (LUP) (n=23) } \\
\cline { 3 - 5 } & & $\begin{array}{c}\text { Annual crop } \\
\text { land }\end{array}$ & $\begin{array}{c}\text { Industrial and } \\
\text { business land }\end{array}$ & $\begin{array}{c}\text { Residential } \\
\text { land }\end{array}$ \\
\hline \multirow{2}{*}{ 1 Actual annual crop } & R-Square & 0.579 & 0.086 & 0.069 \\
land & P-value & 0.000 & 0.499 & 0.226 \\
& Slope & $1.112^{* * *}$ & -14.140 & -2.083 \\
\hline \multirow{3}{*}{ 2 Actual industrial and } & R-Square & 0.043 & 1.000 & 0.064 \\
& P-value & 0.590 & 0.000 & 0.512 \\
& Slope & -0.005 & $1.007 * * *$ & 0.051 \\
\hline \multirow{5}{*}{ 3 Actual residential land land } & R-Square & 0.000 & 0.008 & 0.400 \\
& P-value & 0.976 & 0.825 & 0.001 \\
& Slope & 0.001 & -0.280 & $0.539 * * *$ \\
\hline \multirow{2}{*}{ 4 Food } & R-Square & 0.579 & 0.068 & 0.069 \\
& P-value & 0.000 & 0.499 & 0.226 \\
& Slope & $4.434 * * *$ & -56.388 & -8.305 \\
\hline \multirow{2}{*}{ 5 Population } & R-Square & 0.000 & 0.292 & 0.672 \\
& P-value & 0.990 & 0.133 & 0.000 \\
& Slope & 0.024 & 88.503 & $40.146 * * *$ \\
\hline & R-Square & 0.048 & 0.793 & 0.067 \\
& P-value & 0.573 & 0.001 & 0.502 \\
& Slope & -0.022 & $3.944 * * *$ & 0.231 \\
\hline
\end{tabular}

$*, * *, * * *$ significant at $0.05,0.01,0.001$, respectively. Source: Own calculation

Table 3.3 shows the correlation between intended change and actual change of land use in 23 communes from 2000 to 2010. 
Table 3.3 Correlation between intended change and actual change of land use

\begin{tabular}{|c|c|c|c|c|c|c|}
\hline \multirow{2}{*}{$\begin{array}{c}\text { Actual land use } \\
2010 \text { - LUP } \\
\text { (Intended } \\
\text { change) }\end{array}$} & & \multicolumn{5}{|c|}{$\begin{array}{l}\text { Actual land use } 2010 \text { - Actual land use } 2000 \\
\text { (Actual change) }(\mathrm{n}=23)\end{array}$} \\
\hline & & Agriculture & Residence & Industry & Forest & Unused \\
\hline \multirow{3}{*}{ Agriculture } & R-Square & 0.776 & 0.068 & 0.012 & 0.086 & 0.019 \\
\hline & P-value & 0.000 & 0.228 & 0.617 & 0.175 & 0.529 \\
\hline & Slope & $1.619 * * *$ & 0.053 & -0.012 & -1.924 & -0.882 \\
\hline \multirow{3}{*}{ Residence } & R-Square & 0.082 & 0.789 & 0.008 & 0.162 & 0.035 \\
\hline & P-value & 0.185 & 0.000 & 0.685 & 0.057 & 0.392 \\
\hline & Slope & 3.615 & $1.244 * * *$ & -0.069 & 18.166 & 8.19 \\
\hline \multirow{3}{*}{ Industry } & R-Square & 0.002 & 0.000 & 0.832 & 0.031 & 0.028 \\
\hline & P-value & 0.852 & 0.93 & 0 & 0.419 & 0.446 \\
\hline & Slope & -40.409 & -2.091 & $54.055 * * *$ & 619 & -567.136 \\
\hline \multirow{3}{*}{ Forest } & R-Square & 0.163 & 0.093 & 0.024 & 0.416 & 0.308 \\
\hline & P-value & 0.056 & 0.157 & 0.478 & 0.001 & 0.006 \\
\hline & Slope & -0.089 & 0.007 & 0.002 & $\mathbf{0 . 5 1} * *$ & 0.426 \\
\hline \multirow{3}{*}{ Unused } & R-Square & 0.039 & 0.054 & 0.009 & 0.114 & 0.589 \\
\hline & P-value & 0.366 & 0.287 & 0.663 & 0.116 & 0.000 \\
\hline & Slope & 0.095 & -0.012 & -0.003 & -0.58 & $-1.279 * * *$ \\
\hline
\end{tabular}

$*, * *, * * *$ significant at $0.05,0.01,0.001$, respectively. Source: Own calculation

The data in table 3.3 proves that intended change (between actual land use 2010 and LUP) and actual change (between actual land use 2010 and actual land use 2000) were significantly correlated for all land use types. Specifically, for agriculture, 1 ha or $1 \%$ more in intended change was equivalent to 1.6 ha or $1.6 \%$ more in actual increase. For residence, 1 ha or $1 \%$ more in planned change, it increased 1.2 ha or $1.2 \%$ in actual change. In term of industrial land, 1 ha or $1 \%$ more in intended change, the actual change increased 54 ha or $54 \%$. For 1 ha or $1 \%$ more planned forest area, it increased 0.5 ha or $0.5 \%$ in actual change. For the unused land, the correlation was negative. In sum, a substantial impact of LUP2000 on actual development appears at the municipality level is visible, however, as correlation coefficients (slope) vary and rarely approach +1.0 , the actual spatial influence is limited. 
Nota bene, this analysis was conducted at the municipality level, not at the level of the single parcels of land to which a specific land use was assigned. I.e. the analysis indicates a high positive correlation even in potential cases where the intended changes had happened somewhere else as long as these deviations balance at the municipality level. Thus, the actual spatial importance of LUP2010 may be overestimated.

\subsubsection{Opinion of resource managers and officials}

To reinforce the correlation between LUP and socio-economic development from 2001 to 2010, the interview of natural resources management officials and authorities of 22 communes and one town in Maichau District was carried out under concrete questions focused on three main aspects: (1) Participation in LUP; (2) Contribution of LUP to socioeconomic development; (3) Effect of LUP on environment. Additionally, the area's increases and decreases of different land use types in LUP were also extracted as independent variables.

Table 3.4 shows the influence that would be expected if LUP2000 had worked perfectly. The table has depicts three expected influences: + Positive; - Negative; and 0: No influence (table 3.4). 
Table 3.4 Expectancy of LUP

\begin{tabular}{|c|c|c|c|c|c|}
\hline \multirow[b]{2}{*}{ Dependent variables } & \multicolumn{5}{|c|}{ Independent variables } \\
\hline & $\begin{array}{c}\text { Increase of } \\
\text { annual crop } \\
\text { land }\end{array}$ & $\begin{array}{l}\text { Increase } \\
\text { of } \\
\text { industrial } \\
\text { and } \\
\text { business } \\
\text { land }\end{array}$ & $\begin{array}{c}\text { Increase } \\
\text { of forest } \\
\text { land }\end{array}$ & $\begin{array}{l}\text { Increase } \\
\text { of } \\
\text { residential } \\
\text { land }\end{array}$ & $\begin{array}{c}\text { Decrease } \\
\text { of } \\
\text { unused } \\
\text { land }\end{array}$ \\
\hline $\begin{array}{l}1 \text { Contribution of LUP to } \\
\text { economic growth }\end{array}$ & + & + & 0 & 0 & 0 \\
\hline $\begin{array}{l}2 \text { Contribution of LUP to } \\
\text { agricultural development }\end{array}$ & + & 0 & - & 0 & 0 \\
\hline $\begin{array}{l}3 \text { Contribution of LUP to } \\
\text { non-agricultural development }\end{array}$ & 0 & + & 0 & 0 & 0 \\
\hline $\begin{array}{l}4 \text { Contribution of LUP to } \\
\text { residential development }\end{array}$ & 0 & 0 & 0 & + & 0 \\
\hline $\begin{array}{l}5 \text { Contribution of LUP to } \\
\text { reforestation }\end{array}$ & - & 0 & + & 0 & + \\
\hline $\begin{array}{l}6 \text { Contribution of LUP to } \\
\text { food security }\end{array}$ & + & - & - & 0 & + \\
\hline $\begin{array}{l}7 \text { Contribution of LUP to } \\
\text { landslide preventing }\end{array}$ & - & - & + & - & + \\
\hline $\begin{array}{l}8 \text { Contribution of LUP to } \\
\text { erosion preventing }\end{array}$ & - & - & + & - & + \\
\hline $\begin{array}{l}9 \text { Contribution of LUP to } \\
\text { change of labour use }\end{array}$ & - & + & - & - & + \\
\hline
\end{tabular}

+: Positive; - : Negative; 0: No influence 
Table 3.5 Descriptive statistics of interview of communal officials

\begin{tabular}{|c|c|c|c|c|}
\hline Variables & $\begin{array}{c}\text { Mean } \\
(\mathrm{n}=23)\end{array}$ & $\begin{array}{c}\text { Std. } \\
\text { deviation }\end{array}$ & Min & Max \\
\hline \multicolumn{5}{|l|}{ Dependent variables } \\
\hline $\begin{array}{l}1 \text { Participation of authority in making } \\
\left.\text { LUP (Yes }=1 ; \mathrm{No}_{0}=0\right)\end{array}$ & 1 & 0.0000 & 1 & 1 \\
\hline $\begin{array}{l}2 \text { Participation of local people in making } \\
\text { LUP }(\text { Yes }=1 ; \mathrm{No}=0)\end{array}$ & 0 & 0.0000 & 0 & 0 \\
\hline $\begin{array}{l}3 \text { Contribution of LUP to economic } \\
\text { growth }(\text { Low }(<10 \%)=1 \text {, medium }(10-15 \%)= \\
2 ; \text { High }(>15 \%)=3)\end{array}$ & 2.0435 & 0.63806 & 1 & 3 \\
\hline $\begin{array}{l}4 \text { Contribution of LUP to agricultural } \\
\text { development (Low }(<10 \%)=1 \text {, medium }(10- \\
15 \%)=2 ; \text { High }(>15 \%)=3)\end{array}$ & 2.2174 & 0.73587 & 1 & 3 \\
\hline $\begin{array}{l}5 \text { Contribution of LUP to non- } \\
\text { agricultural development }(\text { Low }(<10 \%)=1 \text {, } \\
\text { medium }(10-15 \%)=2 ; \text { High }(>15 \%)=3)\end{array}$ & 1.4783 & 0.73048 & 1 & 3 \\
\hline $\begin{array}{l}6 \text { Contribution of LUP to residential } \\
\text { development }(\text { Low }=1, \text { medium }=2 ; \text { High }=3)\end{array}$ & 1.6957 & 0.55880 & 1 & 3 \\
\hline $\begin{array}{l}7 \text { Contribution of LUP to food security } \\
(\text { Low }=1, \text { medium }=2 ; \mathrm{High}=3 \text { ) }\end{array}$ & 2.0435 & 0.82453 & 1 & 3 \\
\hline $\begin{array}{l}8 \text { Contribution of LUP to landslide } \\
\text { preventing }(\text { Low }=1, \text { medium }=2 ; \text { High }=3)\end{array}$ & 1.7391 & 0.61919 & 1 & 3 \\
\hline $\begin{array}{l}9 \text { Contribution of LUP to erosion } \\
\text { preventing }(\text { Low }=1, \text { medium }=2 ; \text { High }=3 \text { ) }\end{array}$ & 1.9130 & 0.59643 & 1 & 3 \\
\hline $\begin{array}{l}10 \text { Contribution of LUP to reforestation } \\
(\text { Low }=1, \text { medium }=2 ; \mathrm{High}=3)\end{array}$ & 1.6087 & 0.65638 & 1 & 3 \\
\hline $\begin{array}{l}11 \text { Contribution of LUP to change of } \\
\text { labour use }(\text { Low }=1, \text { medium }=2 ; \text { High }=3)\end{array}$ & 1.4783 & 0.73048 & 1 & 3 \\
\hline \multicolumn{5}{|l|}{ Independent variables (LUP) } \\
\hline 1 Increase of annual crop land (ha) & 2.2804 & 37.3315 & -94.3100 & 76.2300 \\
\hline 2 Increase of forest land (ha) & 321.8461 & 397.9902 & 0.9100 & $1,966.7500$ \\
\hline 3 Increase of residential land (ha) & 3.0596 & 2.8041 & 0.3900 & 15.1000 \\
\hline 4 Increase of industrial land (ha) & 0.9322 & 2.2712 & 0.0000 & 9.5500 \\
\hline 5 Decrease of unused land (ha) & 364.2343 & 395.3139 & 55.3300 & $2,029.8800$ \\
\hline
\end{tabular}

Source: Own investigation and calculation

The data in table 3.5 shows that LUP in the district was made in 2000 without local people's participation, Evans (2004: p21-36) argues that the compromise with local people is very important in planning to achieve a balanced development. There was merely the participation of authorities and natural resources management officials in the making of LUP. 
Table 3.6 Correlation between LUP and contribution of LUP to socio-economic development

\begin{tabular}{|c|c|c|c|c|c|c|}
\hline \multirow{2}{*}{ Variables } & & \multicolumn{5}{|c|}{ Independent variables } \\
\hline & & $\begin{array}{c}\text { Increase of } \\
\text { annual crop } \\
\text { land }\end{array}$ & $\begin{array}{l}\text { Increase } \\
\text { of } \\
\text { industrial } \\
\text { and } \\
\text { business } \\
\text { land } \\
\end{array}$ & $\begin{array}{l}\text { Increase } \\
\text { of forest } \\
\text { land }\end{array}$ & $\begin{array}{l}\text { Increase of } \\
\text { residential } \\
\quad \text { land }\end{array}$ & $\begin{array}{l}\text { Decrease } \\
\text { of unused } \\
\text { land }\end{array}$ \\
\hline \multirow{3}{*}{$\begin{array}{l}1 \text { Contribution of } \\
\text { LUP to economic } \\
\text { growth }\end{array}$} & R-Square & 0.299 & 0.304 & 0.018 & 0.002 & 0.006 \\
\hline & P-value & 0.007 & 0.006 & 0.539 & 0.856 & 0.721 \\
\hline & Slope & $0.009 * *$ & $0.155^{* *}$ & 0.000 & 0.009 & 0.000 \\
\hline \multirow{3}{*}{$\begin{array}{l}2 \text { Contribution of } \\
\text { LUP to } \\
\text { agricultural } \\
\text { development }\end{array}$} & R-Square & 0.753 & 0.010 & 0.058 & 0.001 & 0.025 \\
\hline & P-value & 0.000 & 0.652 & 0.268 & 0.896 & 0.475 \\
\hline & Slope & $0.017 * * *$ & 0.032 & 0.000 & -0.008 & 0.000 \\
\hline \multirow{3}{*}{$\begin{array}{l}3 \text { Contribution of } \\
\text { LUP to non- } \\
\text { agricultural } \\
\text { development }\end{array}$} & R-Square & 0.031 & 0.653 & 0.026 & 0.005 & 0.021 \\
\hline & P-value & 0.420 & 0.000 & 0.464 & 0.752 & 0.510 \\
\hline & Slope & 0.003 & $0.260 * * *$ & 0.000 & -0.018 & 0.000 \\
\hline \multirow{3}{*}{$\begin{array}{l}4 \text { Contribution of } \\
\text { LUP to residential } \\
\text { development }\end{array}$} & R-Square & 0.07 & 0.011 & 0.120 & 0.524 & 0.165 \\
\hline & P-value & 0.222 & 0.630 & 0.105 & 0.000 & 0.054 \\
\hline & Slope & 0.004 & 0.026 & 0.000 & $0.144 * * *$ & 0.001 \\
\hline \multirow{3}{*}{$\begin{array}{l}5 \text { Contribution of } \\
\text { LUP to } \\
\text { reforestation }\end{array}$} & R-Square & 0.176 & 0.002 & 0.595 & 0.156 & 0.544 \\
\hline & P-value & 0.046 & 0.838 & 0.000 & 0.055 & 0.000 \\
\hline & Slope & $-0.007 *$ & 0.013 & $0.001 * * *$ & 0.095 & $0.001 * * *$ \\
\hline \multirow{3}{*}{$\begin{array}{l}6 \text { Contribution of } \\
\text { LUP to food } \\
\text { security }\end{array}$} & R-Square & 0.687 & 0.024 & 0.151 & 0.054 & 0.096 \\
\hline & P-value & 0.000 & 0.481 & 0.067 & 0.285 & 0.150 \\
\hline & Slope & $0.018 * * *$ & 0.056 & 0.000 & -0.068 & 0.000 \\
\hline \multirow{3}{*}{$\begin{array}{l}7 \text { Contribution of } \\
\text { LUP to landslide } \\
\text { preventing }\end{array}$} & R-Square & 0.134 & 0.000 & 0.528 & 0.208 & 0.506 \\
\hline & P-value & 0.086 & 0.963 & 0.000 & 0.029 & 0.000 \\
\hline & Slope & -0.006 & -0.003 & $0.001 * * *$ & $0.101 *$ & $0.001 * * *$ \\
\hline \multirow{3}{*}{$\begin{array}{l}8 \text { Contribution of } \\
\text { LUP to erosion } \\
\text { preventing }\end{array}$} & R-Square & 0.149 & 0.018 & 0.441 & 0.144 & 0.403 \\
\hline & P-value & 0.069 & 0.537 & 0.001 & 0.074 & 0.001 \\
\hline & Slope & -0.006 & -0.036 & $0.001 * * *$ & 0.081 & $0.001 * * *$ \\
\hline \multirow{3}{*}{$\begin{array}{l}9 \text { Contribution of } \\
\text { LUP to change of } \\
\text { labour use }\end{array}$} & R-Square & 0.096 & 0.611 & 0.017 & 0.004 & 0.012 \\
\hline & P-value & 0.150 & 0.000 & 0.549 & 0.769 & 0.622 \\
\hline & Slope & 0.006 & $0.251 * * *$ & 0.000 & -0.017 & 0.000 \\
\hline
\end{tabular}

$*, * *, * * *$ significant at $0.05,0.01,0.001$, respectively. Source: Own calculation 
The contribution of LUP to economic development was claimed to be of great importance. Indeed, the contribution socio-economic development was rated as between 1.5 and 2.2 at a three point scale (1: low, 2: medium, 3: high importance). The strongest influence was assumed for agricultural development (table 3.5).

Table 3.6 shows that there is a significant correlation between the influence that municipality level interviewees attribute to LUP 2000 and actual socio-economic development from 2001 to 2010. For example, the increase of annual crops and industrial land affected largely the agricultural and non-agricultural development, respectively.

\subsection{Conclusions and discussions}

Local land managers regard Land Use Planning as a low-to-medium to medium effective tool to shape district development. Overall indicators of socio-economic development correlate well with the total areas assigned to the land use categories of the LUP 2000. Thus, it can be said that LUP contributes positively to sustainable development because it provides space for these developments, especially as land inputs for agricultural and forest production. However, at the level of the detailed changes proposed in LUP 2000 versus the actual changes at the municipality level, substantial deviations from the plan are commonly observed. Also, this result has to be put into perspective: The deviations in the residential and agricultural land use categories - which form the core of the following analyses on landslide susceptibility - are among the lowest at the municipality level. For both categories, actual change is highly correlated with planned changes $(p<0.001)$, and the proportionality factors are roughly 1.2 and 1.6. So the null-hypothesis that there is no relation between plan and actual development is clearly rejected.

Certainly, additional high resolution analyses would be desirable as well as qualitative insights into the "real" interaction of plan and actual development. Nevertheless, the results of this chapter can be regarded as supporting the notion that LUP does influence local development. Thus, scientific endeavors to improve the capacity of Vietnamese Land Use Planning by the incorporation of landslide risk cannot and should not be disregarded because a low effectiveness of Land Use Planning itself. 


\section{CHAPTER 4: LANDSLIDE SUSCEPTIBILITY IN MAICHAU DISTRICT, HOABINH PROVINCE IN VIETNAM}

The chapter presents the determination of landslide susceptibility using Analytic Hierarchy Process (AHP) and GIS in the whole district. Three categories of landslide susceptibility were defined: low, moderate and high susceptibility. The resulting landslide susceptibility map was tested against data from an investigation of actual landslides form 2000-2010.

\subsection{Definition of landslide}

Natural hazards like landslides, avalanches, floods and debris flows can result in enormous property damage and human casualties in mountainous regions. The wide spectrum of landslide phenomena, the complexity and variability of its interactions with the environment (both natural and human) make the acceptance of a single definition of landslide hazard unsuitable (Guzzetti et al., 1999). Landslide is defined as the movement of soil-slip-debris triggered by intensive rainfalls, which leads to extreme destruction of natural conditions and causes the casualties. A landslide, defined as the movement of a mass of rock, earth or debris down a slope (Cruden, 1991), is a geological process which includes a wide range of ground movement, such as rock falls, deep failure of slopes and shallow debris flows, which can occur in offshore, coastal and onshore environments. Additionally, each time a landslide occurs, the topographic, geological and hydrological settings of the slope change, often dramatically, giving rise to different conditions of instability. These changes allow geomorphologists to identify landslides and understand mechanisms and causes of failures, but limit their ability to forecast reactivations of landslides. According to Varnes (1984: p10) the term 'landslide' comprises almost all types of mass movement on slopes including rock-falls, topples and debris flows. Moreover, Sidle and Ochiai (2006: p1-2) defined landslides as "a variety of processes that result in the downward and outward movement of slope-forming materials composed of natural rocks, soil, artificial fill, or combinations of these materials"

Landslides are among the most hazardous natural disasters (Guzzetti et al., 1999) and caused by various factors, including: earthquakes, rainfall and rapid snowmelt, and 
influenced by multiple factors, such as topography, soil and rock types, fractures, but most of the landslide area is rainfall-induced and the rate of occurrence of the meteorological events trigger landslides (Chau et al., 2004; Guzzetti et al., 2005). According to Guzzetti et al. (1999) landslides in a specific area depend on natural conditions, land-use and human activities. In which, natural conditions, such as: geomorphology and climate affect more landslides in comparison with others. Fernandes et al. (2004) also pointed to the fact that contributing area and hillslope form are the main topographic attributes defining critical conditions for landslides. Guzzetti et al. (2009) found a relationship between landslide area and landslide volume in order to determine the effects of hazard, risks and landslide magnitude.

\subsection{Analytic Hierarchy Process (AHP)}

The Analytic Hierarchy Process (AHP) is recently used widely in different fields. Actually It has been used in business, social studies, research and development, defense and others (Bhushan \& Rai, 2004). Expert' opinions, intuition of analyst are used in AHP. Therefore, the accuracy of AHP' results depends significantly on experience and ability of analyst.

The Analytic Hierarchy Process (AHP) is a pair-wise comparison method in the field of multicriteria analysis (Saaty, 1980). AHP is a multicriteria decision making approach in which factors are arranged in a hierarchic structure. It has become a widely known method for solving discrete multiple criteria problems (Pekka \& Jyrki, 2001: p37). It helps to structure the decision-maker's thoughts and organizes the problem in a manner that is simple to follow and analyze. AHP is a basic approach to decision making (Saaty, 1990) designed to cope with both the rational and the intuitive to select the best from a number of alternatives, evaluated with respect to several criteria (Saaty \& Vargas, 2001).

The results of AHP analysis are consulted in different industries, in which decision making plays vital role on natural resources management. Using the results of AHP analysis is one of the many ways to support decision making. In the AHP process, the decision maker carries out single pair-wise comparison judgments, which are then used to develop overall priorities for ranking the decision making alternatives. AHP also helps to prioritize different decision making criteria at various scales (Saaty, 1977). 
AHP is based on the idea of hierarchically structure a decision making problem (Duc, 2006). The hierarchy allows the assessment of the contribution that an individual criterion at lower levels makes to a criterion at higher levels of the hierarchy. AHP has three basic steps (Duc, 2006; Saaty, 1990). It begins by setting up the overall goal (For example: landslide analysis) into a number of criteria and sub-criteria. The goal itself represents the top level of the hierarchy. Major criteria comprise level one, sub-criteria make up level two, and more.

The second basic step is pair-wise comparison judgment. Within each level of the hierarchy, the importance between each pair of criteria to the overall goal is evaluated. The nine-point fundamental scale is used for this evaluation. An intensity of importance is assigned to each pair-wise within each level. After that, comparison matrices are used to weight the criteria. The assignation for each pair-wise comparison in each level of hierarchy contains expert opinions regarding to the relative importance of criterion if experts do the AHP. However, it is clear from a range of studies that even expert opinions on ranking of attributes may differ substantially (Nath et al., 2000).

According to Saaty and Vargas (2001) and Saaty (1990), a fundamental scale is used in making single pair-wise comparisons. The fundamental scale consists of verbal judgments (intensity of importance) ranging from equal to extreme (equal, moderately more, strongly more, very strongly more, extremely more) corresponding to the numerical judgments (1, 3, 5, 7, 9), and compromises between these values. Therefore, the fundamental scale consists of numbers from 1-9 (Table 4.1). The number 1 indicates an equal priority/importance, and number 9 is the highest priority or importance.

Pair-wise comparison between criteria in each level is a crucial step of AHP to identify the relative importance (Duc, 2006; Saaty, 1990). Pair-wise comparisons generated for the levels of the hierarchy contain expert opinion regarding the relative importance of criterion (Saaty, 1987). For each level in the hierarchy, it is necessary to know whether the pairwise comparison has been consistent in order to accept the results of the weighting. The judgment phase of the analytic hierarchy process requires the following scale of absolute values to express judgments in making paired comparisons.

The third or final step is to establish the composite or final priority of criteria (Saaty, 1990). The comparison matrices are used to weight the criteria. The matrices are used in 
each level and each pair-wise is compared together under fundamental scales.

The criteria in each level are arranged in a reciprocal matrix (Ahn, 2000). According to Saaty (1990): Given n elements in a level of hierarchy, one may first make a pass through them by comparing one element with another, dropping it and picking another if that one is perceived to be larger and continuing the comparison. The largest element, therefore, is selected in n-1 such comparisons. The process is repeated for the remaining n-1 elements to identify the second largest element and so on. In the end, the elements would be arranged in descending order.

Table 4.1 The fundamental scale

\begin{tabular}{|c|c|c|}
\hline $\begin{array}{l}\text { Intensity of } \\
\text { importance }\end{array}$ & Definition & Explanation \\
\hline 1 & Equal importance & $\begin{array}{l}\text { Two options contribute equally to the } \\
\text { objective }\end{array}$ \\
\hline 2 & Weak & \\
\hline 3 & Moderate importance & $\begin{array}{l}\text { Experience and judgment slightly } \\
\text { favor one option over another }\end{array}$ \\
\hline 4 & Moderate plus & \\
\hline 5 & Strong importance & $\begin{array}{l}\text { Experience and judgment strongly } \\
\text { favor one option over another }\end{array}$ \\
\hline 6 & Strong plus & \\
\hline 7 & $\begin{array}{l}\text { Very strong or demonstrated } \\
\text { importance }\end{array}$ & $\begin{array}{l}\text { An option is favored very strongly } \\
\text { over another; its dominance } \\
\text { demonstrated in practice. }\end{array}$ \\
\hline 8 & Very, very strong & \\
\hline 9 & Extreme importance & $\begin{array}{l}\text { The evidence favoring one option } \\
\text { over another is of the highest possible } \\
\text { order of affirmation }\end{array}$ \\
\hline
\end{tabular}

Source: Saaty (1977, 1980); Saaty \& Vargas (2001)

Comparison matrix and equations are presented following:

Comparison matrix: 


\begin{tabular}{c|ccccc} 
& $\mathrm{A}_{1}$ & $\mathrm{~A}_{2}$ & $\ldots$ & $\mathrm{A}_{\mathrm{n}}$ & \\
\hline $\mathrm{A}_{1}$ & $\mathrm{a}_{11}$ & $\mathrm{a}_{12}$ & $\ldots$ & $\mathrm{a}_{1 \mathrm{n}}$ & \\
$\mathrm{A}_{2}$ & $\mathrm{a}_{21}$ & $\mathrm{a}_{22}$ & $\ldots$ & $\mathrm{a}_{2 \mathrm{n}}$ & \\
$\ldots$ & $\ldots$ & $\ldots$ & $\ldots$ & $\ldots$ \\
$\mathrm{A}_{\mathrm{n}}$ & $\mathrm{a}_{\mathrm{n} 1}$ & $\mathrm{a}_{\mathrm{n} 2}$ & $\ldots$ & $\mathrm{a}_{\mathrm{nn}}$ & \\
& & & & &
\end{tabular}

Fig. 4.1 Reciprocal comparison matrix

A: Criteria (From 1 to $\mathrm{n}$ )

$\mathrm{W}_{\mathrm{i}}$ : Weight of criterion i ( 1 to $\left.\mathrm{n}\right)$.

$a_{i j}$ : Fundamental scale value of difference between criterion $i$ and $j$ (from 1-9).

Equations:

$$
W_{i}=\frac{\sum_{j=1}^{n} \frac{a_{i j}}{\sum_{i=1}^{n} a_{i j}}}{n}
$$

The Consistency Ratio (CR) is a measure of how much variation is allowed for reasonable results, it is expected to be less than 10 percent for the reasonable result. The CR calculation is described as in the following formula from the matrix goal calculation, the $\lambda_{\max }$ value can be gained and later it is used to count Consistency Ratio $(\mathrm{CR})$ and $\mathrm{W}_{\mathrm{i}}$ which becomes the priority vector. The formula of Consistency Ratio (CR) got from the Consistency Index $(\mathrm{CI})$ is, as follows:

$$
\begin{aligned}
& C I=\frac{\lambda_{\text {max }}-n}{n-1} \\
& C R=\frac{C I}{R I}
\end{aligned}
$$

where $\lambda_{\max }$ : The maximum eigen value

CI: Consistency Index 


\section{CR: Consistency Ratio}

RI: Random Index

$\mathrm{n}$ : The numbers of criteria or sub-criteria in each pair-wise comparison matrix

In the Analytic Hierarchy Process, a hierarchic structure is arranged descending from an overall goal to criteria, sub-criteria and alternatives in successive levels (Saaty, 1990).

Goal: Defined as main purpose of valuation in the hierarchy structure. It is the final result that research needs to achieve, for instance: land use suitability (Duc, 2006), wetland conservation (Wattage \& Mardle, 2008), landslide susceptibility, etc.

Criteria: Main criteria in level one are used in the valuation. These criteria are chosen carefully from many criteria to achieve the goal. In own research for example, 5 criteria were selected for the goal of valuating the level of landslide susceptibility.

Sub-criteria: Based on the quality and equity out of main criteria, sub-criteria are determined to achieve the goal in the hierarchy structure.

Alternatives: The alternatives of goal are ranked using several quantitative and/or qualitative criteria, depending on how they contribute in achieving an overall goal (Anagnostopoulos \& Vavatsikos, 2006; Saaty \& Vargas, 2001). For example: three alternatives of landslide susceptibility were established including high, moderate and low susceptibility by purpose of the research, expert's opinions, experience and intuition.

The AHP works by developing priorities for criteria and accompanying alternatives. It is estimated that the allocation of weights using AHP is a robust method (Saaty \& Ozdemir, 2003; Wattage \& Mardle, 2008). The pair-wise comparisons are performed to derive priorities for criteria with respect to the goal (Saaty, 1990, 2008).

\subsection{Determination of landslide susceptibility in Maichau District, Hoabinh Province, Vietnam}

In this study, I use the AHP method to construct a spatially explicit model of landslide risks for the case study area. This chapter documents the data used and methodological 
decisions made in the construction of the landslide model. Thus, relatively little attention is paid to some of the details of my interaction with scientific and local experts that I used to inform my analyst choices in the AHP process. In sum, I used culturally accepted, commonly used modes of soliciting expertise based on person and professional acquaintance as well as based on administrative relations, for example, between district and municipality natural resource managers. We need to keep in mind that the overall goal of the study is an assessment of an AHP approach to construct a landslide risk mode, which is then scientifically and economically evaluated (see next chapters). With other words, this is not a social-sciences study on the interactions of the analyst with local experts. The level of detail provided shall enable the reader to generally assess the type of interaction and expertise; most of all to facilitate a general replication of the method in other districts in Vietnam.

\subsubsection{Criteria}

Based on the characteristics of actual landslides, the natural conditions of the research area and the opinion of experts, some criteria are chosen. The occurrence of the landslides is linked to a combination of causative factors, reflecting natural conditions in the study area (Neuhäuser \& Terhorst, 2007). Geology and geological structure are also some causative factors leading to the landslides in different regions (Lee et al., 2002; Parise \& Jibson, 2000; Sidle \& Ochiai, 2006: p41-49). Additionally, soil property and vegetation cover are also used to analyze the landslide susceptibility (Ayalew \& Yamagishi, 2005; Gorsevski et al., 2006; Westen et al., 2006). Therefore, determination of criteria for landslide susceptibility is not a simple task, because it is related to different aspects.

To determine the criteria, the opinions and cooperation with officials and scientists at the Department of Natural Resources and Environment, the Department of Agriculture and Rural development, the Department of Forestry in Hoabinh Province and Maichau District; the Department of Land Use Planning, the Department of Water Resources and the Department of Soil Science at Hanoi University of Agriculture were consulted. In particular, the opinions of natural resources management officials at 22 communes and a town when doing field trip were referred as well. Five criteria, therefore, were selected including: slope, soil types, soil texture, soil depth and vegetation cover. 
The opinions of some experts and officials were consulted to collect and evaluate the AHP criteria in the district. Experts and officials were asked from the Department of Land Use Planning (7 scientists), the Department of Soil Science (5), the Department of Water resource (5) at Hanoi University of Agriculture (HUA), and 5 Officials at the Department of Natural Resources and Environment of Maichau District, 7 Officials at the Department of Natural Resources and Environment of Hoabinh Province, and 23 Official at 22 communes and a town in Maichau District.

The purpose of investigation was to compile and collect criteria for determining landslide susceptibility in the district. Based on the landslide background (detail in section 4.1), the research conditions (detail in chapter 2) and my experience, the list of criteria before investigating data was proposed that I intended to discuss and find the suitable and available criteria for my research:

- $\quad$ soil type; soil depth; soil texture; rock layer; slope,

- vegetation cover,

- climatic condition.

After discussions with experts, rock layer and climatic conditions were dropped because they are the same in the district. Finally, 5 criteria and 21 sub-criteria were investigated

The discussion with scientists and officials was applied in AHP method to determine the relative importance of each criterion towards landslide susceptibility with reciprocal comparison matrices. The following steps of AHP were carried out in the field trip in Vietnam:

- Determining the criteria to use in AHP method: Which criteria were meaningful with landslide susceptibility?

- Arranging the criteria in the AHP matrix: How were criteria ranked in the hierarchy structure?

- Discussing to find the fundamental scale value between two criteria towards landslide susceptibility: Which fundamental scale value should be assigned in comparison matrix? 
- Discussing to select the fundamental scale value between three categories of landslide susceptibility: Which fundamental scale value should be assigned in comparison matrix?

After discussing these issues with national, regional and local experts, the criteria were chosen and the fundamental scale value was averagely calculated by the own intuition in each interviewed department.

\subsubsection{Slope}

Topography is one of the major factors in landslide hazard and risk analysis (Sidle \& Ochiai, 2006: p55; Westen et al., 2006). In Vietnam, slope is normally classified into 3 - 6 categories depending on land use purposes and map scale (Chieu et al., 1999: p163; Dai et al., 2009: p133; Dung et al., 2009: p96; Quy et al., 2005: p33). Actually, the input data of LUP at the district level in Vietnam consists of the slope map with four categories, including: $0^{\circ}-8^{\circ}, 8^{\circ}-$ $15^{\circ}, 15^{\circ}-25^{\circ},>25^{\circ}$. Based on the purposes of research, four categories of slope were chosen for the prediction of landslide susceptibility in the research area. The slope map was built from DEM (Digital Elevation Model) of Maichau District (Anonymous, 2010b).

Digital Elevation Model (DEM) represents spatial variation in altitude (Thien, 2004) and it is a type of raster GIS layer (Khanh, 2009). In a DEM, each cell has a value corresponding to its elevation, so it is a raster of elevation values. There are many applications of DEM that people can implement in various fields. One of the most powerful applications of DEM is adding synthetic hillshading to maps so that the map reader may see the relationship between terrain and map features. A 30-m-resolution DEM was used to contribute the slope map (Ayalew \& Yamagishi, 2005; Chaco'n et al., 2006; Demoulin \& Chung, 2007) with applications of GIS software Arcgis 9.3. In the research, with the help of GIS applications, slope map was built to support for the next research steps.

The slope was divided into four categories, as follows: 
Table 4.2 Categories of slope in Maichau District - Hoabinh Province

\begin{tabular}{ccccc}
\hline No & Categories of slope & Notation & Area (ha) & Proportion (\%) \\
\hline 1 & $0-8^{\circ}$ & $\mathrm{SL}_{1}$ & $8,970.74$ & 16.33 \\
2 & $8-15^{\circ}$ & $\mathrm{SL}_{2}$ & $11,867.75$ & 21.61 \\
3 & $15-25^{\circ}$ & $\mathrm{SL}_{3}$ & $19,677.92$ & 35.82 \\
4 & $>25^{\circ}$ & $\mathrm{SL}_{4}$ & $14,412.26$ & 26.24 \\
\hline & Total & & $54,928.67$ & 100.00 \\
\hline
\end{tabular}

Source: Own calculation

The data indicates that nearly $84 \%$ of the district had slope $>8^{\circ}$. Specially $26 \%$ of total district with slope $>25^{\circ}$ has been restricted by Vietnam Ministry of Agriculture and Rural Development for agricultural activities (Thu, 2009: p3-5). The highest slope areas are found in some communes in the northern and eastern parts of the district where they are basically recommended for forest activities. Zones, with slope $<8^{\circ}$, accounted for $16 \%$ of the total research area and were mainly distributed in some communes in the middle of the district and along the rivers. These areas are estimated as suitable for annual crop planting. 


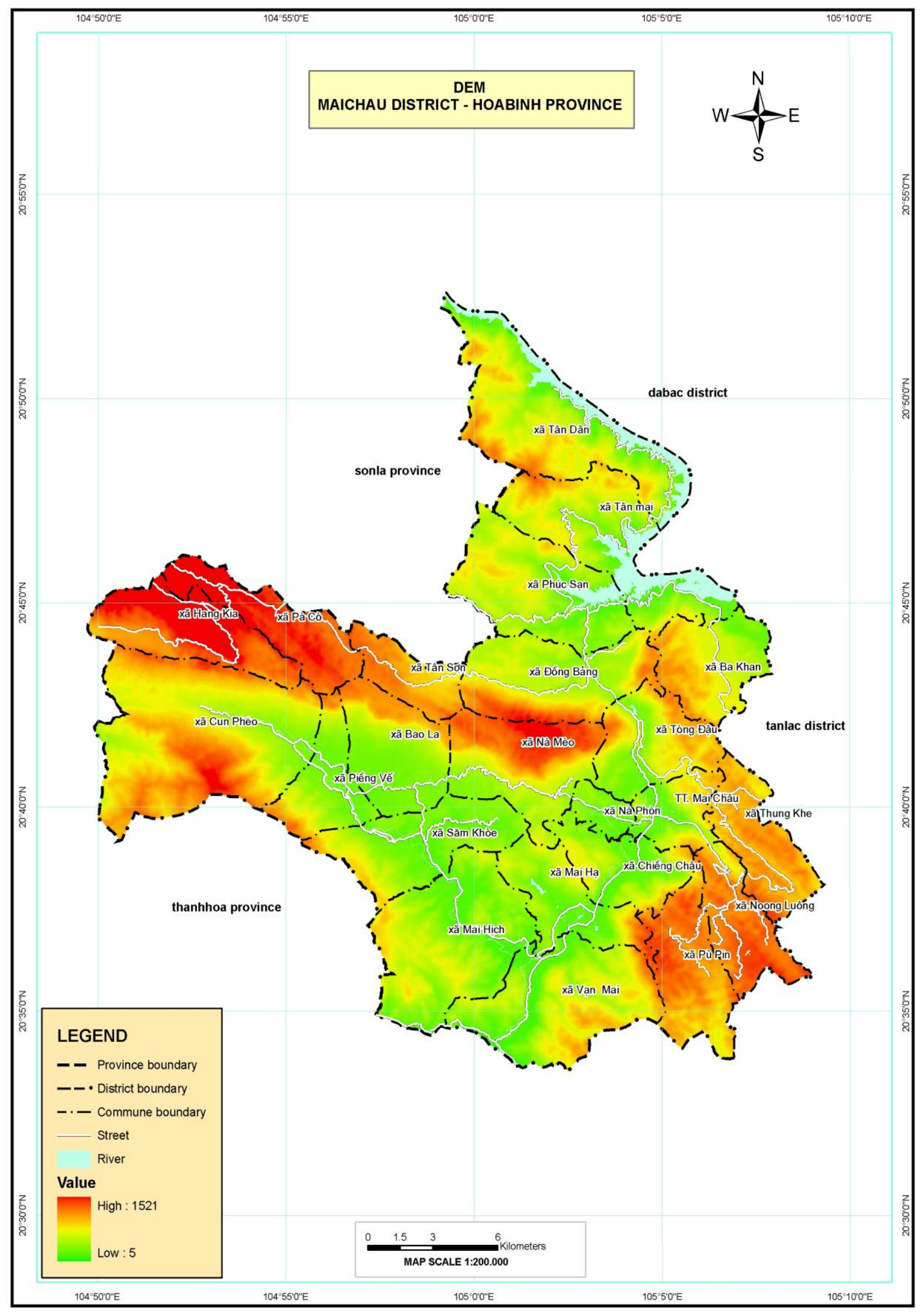

Fig.4.2 Digital Elevation Model (DEM) of Maichau; Source: Anonymous (2010b) 


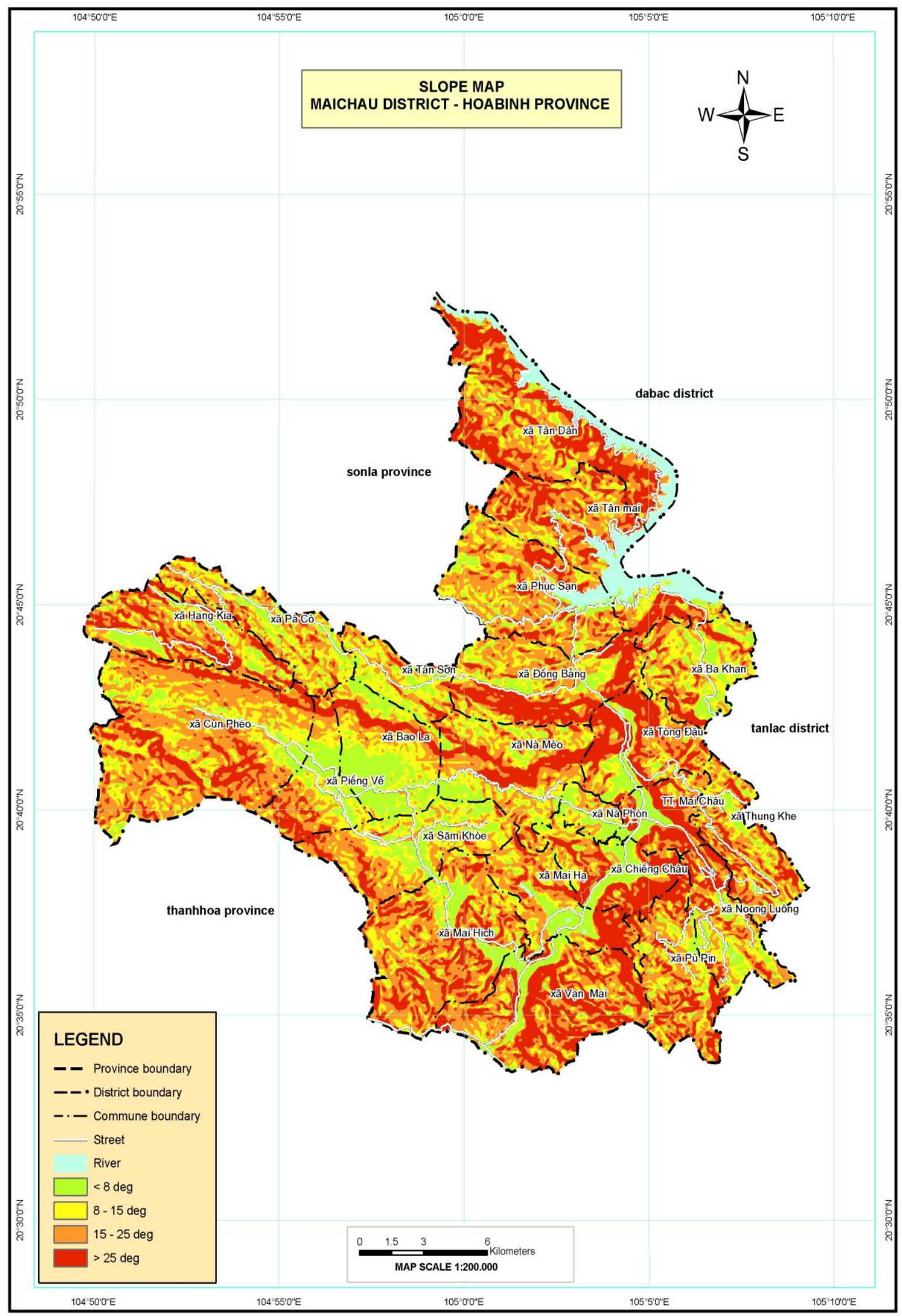

Fig.4.3 Slope map of Maichau; Source: Own calculation 


\subsubsection{Soil types}

Soil type is one of the important components of geology. Soil was formed by long-term geological processes that influenced soil quality (Loi, 2008) and soil structure which directly causes landslide (Khanh, 2009; Long, 2008). Maichau District has a high diversity of soil types. Based on the soil map that resulted by the Institute of Agricultural Planning in 1999, there were six soil types founded in the district, as follows:

- Dystric-Fluvisols (Đất phù sa ngòi suối).

- Calcic-Luvisols (Đất đen trên đá vôi).

- Rhodic-Ferralsols (Đất đỏ trên đá bazan, đá vôi, andezit).

- Ferralic-Acrisols (Đất đỏ vàng trên đá phiến sét, macma axit. Đá cát).

- Gleyic-Acrisols (Đất đỏ vàng biến đổi do trồng lúa nước).

- Humic-Ferrasols (Đất mùn đỏ nâu trên đá vôi).

Table 4.3 Soil types in Maichau District - Hoabinh Province

\begin{tabular}{rlrrr}
\hline No & \multicolumn{1}{c}{ Soil types } & Notation & Area (ha) & Proportion (\%) \\
\hline 1 & Dystric-Fluvisols & FLd & $1,904.47$ & 3.47 \\
2 & Calcic-Luvisols & LVca & 228.25 & 0.42 \\
3 & Rhodic-Ferralsols & FRr & $24,287.69$ & 44.21 \\
4 & Ferralic-Acrisols & ACf & $19,636.36$ & 35.75 \\
5 & Gleyic-Acrisols & ACg & 707.03 & 1.29 \\
6 & Humic-Ferralsols & FRhu & $8,165.87$ & 14.87 \\
\hline & Total & & $54,928.67$ & 100.00 \\
\hline
\end{tabular}

Source: Anonymous (1999)

The data in table 4.3 shows that Rhodic-Ferralsols accounted for roughly $44 \%$ of the total research area, standing at the highest proportion. After that Ferralic-Acrisols and HumicFerralsols were at the second and third position with nearly $36 \%$ and $145 \%$, respectively. Conversely, Calcic-Luvisols occupied only $0.42 \%$, standing at the lowest proportion in the 
district. Higher proportions in comparison with Calcic-Luvisols were Gleyic - Acrisols and Dystric - Fluvisols with $1.3 \%$ and $3.5 \%$, respectively.

1. Dystric - Fluvisols $(\boldsymbol{F L d})$ : This soil type was located normally at low elevation along the rivers and streams below $600 \mathrm{~m}$ above sea level and soil depth varied from medium to thick. It covered about 1,904 ha in Chiengchau, Maihich, Samkhoe, Tongdau, Maiha communes and Maichau town. The soil was characterized by its texture ranging from silty loam to clay loam. The soil reaction was very strong acid with soil $\mathrm{pH}_{\mathrm{kcl}}$ values of 3.92 to 4.23. Soil organic matter at different layers changed from 0.59 to $1.82 \%$. Total Protein, $\mathrm{P}_{2} \mathrm{O}_{5}$ and $\mathrm{K}_{2} \mathrm{O}$ stood at high level with $0.162 \%, 0.143 \%$ and $1.45 \%$, respectively. Available $\mathrm{P}_{2} \mathrm{O}_{5}$ was at medium level with $8.4 \mathrm{mg} / 100 \mathrm{~g}$ soil and $\mathrm{K}_{2} \mathrm{O}$ was at high level with 22.5 $\mathrm{mg} / 100 \mathrm{~g}$ soil. Exchange cations were at low level ranging from 3.4 to $6.4 \mathrm{meq} / 100 \mathrm{~g}$ soil with $\mathrm{Ca}^{++}$and 0.6 to 4.1 with $\mathrm{Mg}^{++}$. General speaking, the soil was medium for total and available phosphorus and potassium (table 4.4).

Table 4.4 Results of soil profile analysis of Dystric - Fluvisols

\begin{tabular}{|c|c|c|c|c|c|c|c|c|c|c|c|c|c|}
\hline \multirow{2}{*}{$\begin{array}{l}\text { Depth } \\
(\mathrm{cm})\end{array}$} & \multirow{2}{*}{$\begin{array}{l}\mathrm{pH} \\
\mathrm{kcl}\end{array}$} & \multirow{2}{*}{$\begin{array}{l}\mathrm{OM} \\
(\%)\end{array}$} & \multicolumn{3}{|c|}{ Total (\%) } & \multicolumn{2}{|c|}{$\begin{array}{c}\text { Available } \\
\text { (mg/100g } \\
\text { soil) }\end{array}$} & \multicolumn{3}{|c|}{$\begin{array}{l}\text { Exchange Cation } \\
\text { (meq mg/100g soil) }\end{array}$} & \multicolumn{3}{|c|}{ Soil texture $(\%) ; \mathrm{mm}$} \\
\hline & & & $\mathrm{N}$ & $\mathrm{P}_{2} \mathrm{O}_{5}$ & $\mathrm{~K}_{2} \mathrm{O}$ & $\mathrm{P}_{2} \mathrm{O}_{5}$ & $\mathrm{~K}_{2} \mathrm{O}$ & $\mathrm{Ca}^{++}$ & $\mathrm{Mg}^{++}$ & CEC & $\begin{array}{c}2- \\
0.02\end{array}$ & $\begin{array}{l}0.02- \\
0.002\end{array}$ & $<0.002$ \\
\hline $0-18$ & 4.21 & 1.82 & 0.162 & 0.143 & 1.45 & 8.4 & 22.5 & 3.4 & 0.6 & 8.77 & 24.85 & 48.82 & 26.33 \\
\hline $\begin{array}{l}18- \\
50 \\
50-\end{array}$ & 4.38 & 1.58 & 0.207 & 0.145 & 1.65 & 6.2 & 14.6 & 6.4 & 2.4 & 13.29 & 20.54 & 52.06 & 27.4 \\
\hline 100 & 3.92 & 0.59 & 0.056 & 0.089 & 1.78 & 5.8 & 10.5 & 6.1 & 2.1 & 12.66 & 29.09 & 34.77 & 36.14 \\
\hline
\end{tabular}

Source: Soil profile analysis 


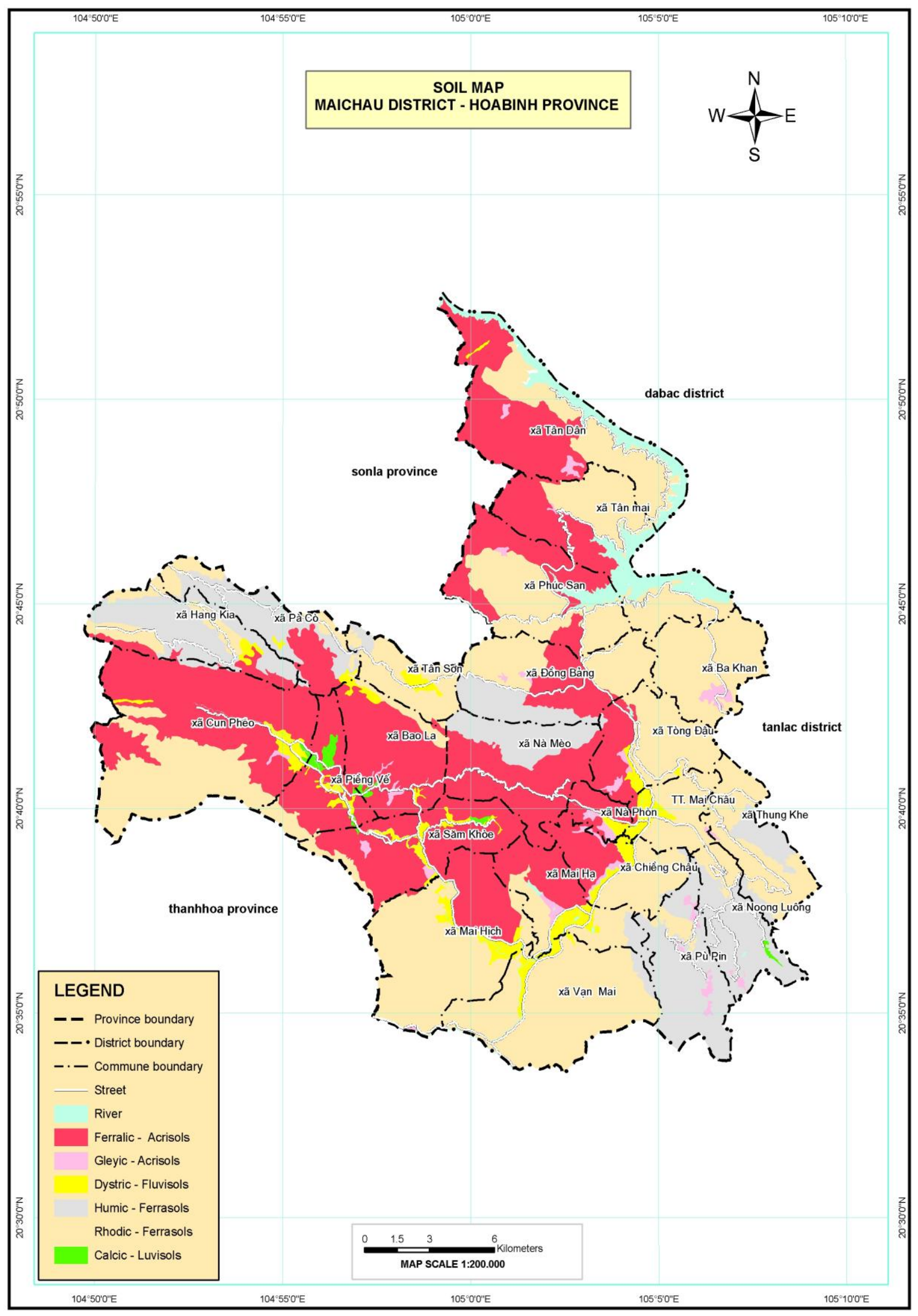

Fig.4.4 Soil map in Maichau District; Source: Anonymous (1999) 
2. Calcic-Luvisols (LVca): Also located at low elevation and low slope, this soil type contained organic accumulation and alkali processes. It was distributed in Vanmai, Xamkhoe communes with 228 ha. Its texture was almost clay loam. The soil reaction was neuter acid with soil $\mathrm{pH}_{\mathrm{kcl}}$ values of 7.37 to 7.30. Soil organic matter at different layers changed from 2.35 to $3.76 \%$. Total Protein, $\mathrm{P}_{2} \mathrm{O}_{5}$ and $\mathrm{K}_{2} \mathrm{O}$ stood at high level with $0.229 \%$, $0.242 \%$ and $1.13 \%$, respectively. Available $\mathrm{P}_{2} \mathrm{O}_{5}$ was at medium level with $8.8 \mathrm{mg} / 100 \mathrm{~g}$ soil and $\mathrm{K}_{2} \mathrm{O}$ was at high level with $9.4 \mathrm{mg} / 100 \mathrm{~g}$ soil. Exchange cations were at high level ranging from 29.70 to $26.00 \mathrm{meq} / 100 \mathrm{~g}$ soil with $\mathrm{Ca}^{++}$and 1.40 to 2.40 with $\mathrm{Mg}^{++}$. Therefore, the soil was high for total phosphorus and potassium and low for available phosphorus and potassium (table 4.5)

Table 4.5 Results of soil profile analysis of Calcic - Fluvisols

\begin{tabular}{|c|c|c|c|c|c|c|c|c|c|c|c|c|c|}
\hline \multirow{2}{*}{$\begin{array}{l}\text { Depth } \\
(\mathrm{cm})\end{array}$} & \multirow{2}{*}{$\begin{array}{l}\mathrm{pH} \\
\mathrm{kcl}\end{array}$} & \multirow{2}{*}{$\begin{array}{l}\mathrm{OM} \\
(\%)\end{array}$} & \multicolumn{3}{|c|}{ Total $(\%)$} & \multicolumn{2}{|c|}{$\begin{array}{c}\text { Available } \\
\text { (mg/100g } \\
\text { soil) }\end{array}$} & \multicolumn{3}{|c|}{$\begin{array}{l}\text { Exchange Cation } \\
\text { (meq mg/100g soil) }\end{array}$} & \multicolumn{3}{|c|}{ Soil texture $(\%) ; \mathrm{mm}$} \\
\hline & & & $\mathrm{N}$ & $\mathrm{P}_{2} \mathrm{O}_{5}$ & $\mathrm{~K}_{2} \mathrm{O}$ & $\mathrm{P}_{2} \mathrm{O}_{5}$ & $\mathrm{~K}_{2} \mathrm{O}$ & $\mathrm{Ca}^{++}$ & $\mathrm{Mg}^{++}$ & CEC & $\begin{array}{c}2- \\
0.02\end{array}$ & $\begin{array}{l}0.02- \\
0.002\end{array}$ & $<0.002$ \\
\hline $0-18$ & 7.31 & 3.76 & 0.229 & 0.242 & 0.93 & 8.8 & 9.4 & 29.7 & 2.40 & 35.56 & 18.11 & 29.28 & 52.61 \\
\hline $\begin{array}{l}18- \\
50\end{array}$ & 7.30 & 3.34 & 0.241 & 0.248 & 0.98 & 8.9 & 7.2 & 28.0 & 2.80 & 37.10 & 17.10 & 23.78 & 59.12 \\
\hline $\begin{array}{l}50- \\
100\end{array}$ & 7.73 & 2.35 & 0.162 & 0.117 & 1.16 & 5.9 & 6.4 & 26.0 & 1.40 & 32.54 & 12.37 & 28.47 & 59.16 \\
\hline
\end{tabular}

Source: Soil profile analysis

3. Rhodic- Ferralsols (FRr): This soil type was located at high slope in the district distributing in most of the communes with 24,286 ha, equivalent to $44.21 \%$ of the total district. The results of soil profile analysis (table 4.5) show that soil texture was clay loam with $>40 \%$ clay. The soil reaction was very strong acid with soil $\mathrm{pH}_{\mathrm{kcl}}$ values of 4.19 to 4.79. Soil organic matter at different layers changed from 0.53 to $3.52 \%$. Total Protein, $\mathrm{P}_{2} \mathrm{O}_{5}$ and $\mathrm{K}_{2} \mathrm{O}$ stood at high level with $0.224 \%, 0.262 \%$ and $0.54 \%$, respectively. Available $\mathrm{P}_{2} \mathrm{O}_{5}$ was at medium level with $8.2 \mathrm{mg} / 100 \mathrm{~g}$ soil and $\mathrm{K}_{2} \mathrm{O}$ was at poor level with $<5$ $\mathrm{mg} / 100 \mathrm{~g}$ soil. Exchange cations were at low level ranging $<3 \mathrm{meq} / 100 \mathrm{~g}$ soil with $\mathrm{Ca}^{++}$and $\mathrm{Mg}^{++}$. Generally, the soil was high for total and low for available phosphorus and potassium. 
Table 4.6 Results of soil profile analysis of Rhodic - Ferralsols

\begin{tabular}{|c|c|c|c|c|c|c|c|c|c|c|c|c|c|}
\hline \multirow{2}{*}{$\begin{array}{l}\text { Depth } \\
(\mathrm{cm})\end{array}$} & \multirow{2}{*}{$\begin{array}{l}\mathrm{pH} \\
\mathrm{kcl}\end{array}$} & \multirow{2}{*}{$\begin{array}{l}\mathrm{OM} \\
(\%)\end{array}$} & \multicolumn{3}{|c|}{ Total (\%) } & \multicolumn{2}{|c|}{$\begin{array}{l}\text { Available } \\
\text { (mg/100g } \\
\text { soil) }\end{array}$} & \multicolumn{3}{|c|}{$\begin{array}{l}\text { Exchange Cation } \\
\text { (meq mg/100g soil) }\end{array}$} & \multicolumn{3}{|c|}{ Soil texture $(\%) ; \mathrm{mm}$} \\
\hline & & & $\mathrm{N}$ & $\mathrm{P}_{2} \mathrm{O}_{5}$ & $\mathrm{~K}_{2} \mathrm{O}$ & $\mathrm{P}_{2} \mathrm{O}_{5}$ & $\mathrm{~K}_{2} \mathrm{O}$ & $\mathrm{Ca}^{++}$ & $\mathrm{Mg}^{++}$ & CEC & $\begin{array}{c}2- \\
0.02\end{array}$ & $\begin{array}{l}0.02- \\
0.002\end{array}$ & $<0.002$ \\
\hline $0-20$ & 4.19 & 3.52 & 0.224 & 0.263 & 0.54 & 8.2 & 4.8 & 3.20 & 0.80 & 8.72 & 29.62 & 30.30 & 40.08 \\
\hline $\begin{array}{l}20- \\
50 \\
50-\end{array}$ & 4.79 & 0.53 & 0.056 & 0.192 & 0.61 & 7.9 & 4.6 & 1.60 & 0.30 & 6.89 & 17.18 & 16.34 & 66.48 \\
\hline 100 & 4.58 & 0.67 & 0.095 & 0.198 & 0.51 & 7.4 & 4.7 & 1.30 & 0.40 & 6.57 & 17.67 & 15.80 & 66.53 \\
\hline
\end{tabular}

Source: Soil profile analysis

4. Ferralic-Acrisols $(\boldsymbol{A C f})$ : This soil type was distributed in most of the district, normally located at slope of $>15^{\circ}$. It covered an area of 19,636 ha. The soil texture was silty loam with $>40 \%$ clay. The soil was endowed with very strong acid $\left(\mathrm{pH}_{\mathrm{kcl}}\right.$ values of 4.40 to 4.65). Humus ranged from 1.46 to 0.47 percent. Total Protein, $\mathrm{P}_{2} \mathrm{O}_{5}$ and $\mathrm{K}_{2} \mathrm{O}$ stood at high level with $0.235 \%, 0.066 \%$ and $1.69 \%$, respectively. Available $\mathrm{P}_{2} \mathrm{O}_{5}$ was at poor level with $2.8 \mathrm{mg} / 100 \mathrm{~g}$ soil and $\mathrm{K}_{2} \mathrm{O}$ was at medium level with $<10 \mathrm{mg} / 100 \mathrm{~g}$ soil. Exchange cations were at low level ranging $<5 \mathrm{meq} / 100 \mathrm{~g}$ soil with $\mathrm{Ca}^{++}$and $\mathrm{Mg}^{++}$.

Table 4.7 Results of soil profile analysis of Ferralic - Acrisols

\begin{tabular}{|c|c|c|c|c|c|c|c|c|c|c|c|c|c|}
\hline \multirow{2}{*}{$\begin{array}{l}\text { Depth } \\
(\mathrm{cm})\end{array}$} & \multirow{2}{*}{$\begin{array}{l}\mathrm{pH} \\
\mathrm{kcl}\end{array}$} & \multirow{2}{*}{$\begin{array}{l}\mathrm{OM} \\
(\%)\end{array}$} & \multicolumn{3}{|c|}{ Total (\%) } & \multicolumn{2}{|c|}{$\begin{array}{c}\text { Available } \\
\text { (mg/100g } \\
\text { soil) }\end{array}$} & \multicolumn{3}{|c|}{$\begin{array}{l}\text { Exchange Cation } \\
\text { (meq mg/100g soil) }\end{array}$} & \multicolumn{3}{|c|}{ Soil texture $(\%) ; \mathrm{mm}$} \\
\hline & & & $\mathrm{N}$ & $\mathrm{P}_{2} \mathrm{O}_{5}$ & $\mathrm{~K}_{2} \mathrm{O}$ & $\mathrm{P}_{2} \mathrm{O}_{5}$ & $\mathrm{~K}_{2} \mathrm{O}$ & $\mathrm{Ca}^{++}$ & $\mathrm{Mg}^{++}$ & CEC & $\begin{array}{c}2- \\
0.02\end{array}$ & $\begin{array}{l}0.02- \\
0.002\end{array}$ & $<0.002$ \\
\hline $0-20$ & 4.40 & 1.46 & 0.235 & 0.066 & 1.69 & 2.8 & 9.9 & 3.40 & 1.30 & 9.36 & 44.19 & 37.50 & 18.31 \\
\hline $\begin{array}{l}20- \\
50\end{array}$ & 4.77 & 0.65 & 0.067 & 0.063 & 1.89 & 2.2 & 9.6 & 1.75 & 0.70 & 9.10 & 37.85 & 37.50 & 24.65 \\
\hline $\begin{array}{l}50- \\
100\end{array}$ & 4.65 & 0.47 & 0.050 & 0.044 & 2.00 & 2.2 & 4.7 & 1.70 & 0.70 & 8.08 & 38.50 & 39.76 & 21.74 \\
\hline
\end{tabular}

Source: Soil profile analysis

5. Gleyic-Acrisols(ACg): This soil type was normally located at a low slope and affected by annual cropping leading to changes of chemical and physical soil. It covered with 707 ha, equivalent to $1.29 \%$ total area. The soil was characterized by its texture ranging from sandy loam to silty loam, and was poor to medium in organic matter (OM: $0.81-1.17 \%$ ), total nitrogen varied from 0.072 to $0.106 \%$, available phosphorus in the soil type varied from 4.0 to $1.5 \mathrm{mg} / 100 \mathrm{~g}$ soil and available potassium from 7.6 to $12.1 \mathrm{mg} / 100 \mathrm{~g}$ soil. 
Exchange cations were at low level ranging $<5$ meq/100g soil with both $\mathrm{Ca}^{++}$and $\mathrm{Mg}^{++}$.

Table 4.8 Results of soil profile analysis of Gleyic - Acrisols

\begin{tabular}{|c|c|c|c|c|c|c|c|c|c|c|c|c|c|}
\hline \multirow{2}{*}{$\begin{array}{l}\text { Depth } \\
(\mathrm{cm})\end{array}$} & \multirow{2}{*}{$\begin{array}{l}\mathrm{pH} \\
\mathrm{kcl}\end{array}$} & \multirow{2}{*}{$\begin{array}{l}\mathrm{OM} \\
(\%)\end{array}$} & \multicolumn{3}{|c|}{ Total (\%) } & \multicolumn{2}{|c|}{$\begin{array}{c}\text { Available } \\
\text { (mg/100g } \\
\text { soil) }\end{array}$} & \multicolumn{3}{|c|}{$\begin{array}{l}\text { Exchange Cation } \\
\text { (meq mg/100g soil) }\end{array}$} & \multicolumn{3}{|c|}{ Soil texture $(\%) ; \mathrm{mm}$} \\
\hline & & & $\mathrm{N}$ & $\mathrm{P}_{2} \mathrm{O}_{5}$ & $\mathrm{~K}_{2} \mathrm{O}$ & $\mathrm{P}_{2} \mathrm{O}_{5}$ & $\mathrm{~K}_{2} \mathrm{O}$ & $\mathrm{Ca}^{++}$ & $\mathrm{Mg}^{++}$ & CEC & $\begin{array}{c}2- \\
0.02\end{array}$ & $\begin{array}{l}0.02- \\
0.002\end{array}$ & $<0.002$ \\
\hline $0-20$ & 4.14 & 1.17 & 0.106 & 0.082 & 1.38 & 4.0 & 12.1 & 3.20 & 0.80 & 8.21 & 50.49 & 34.78 & 14.73 \\
\hline $\begin{array}{l}20- \\
50 \\
50-\end{array}$ & 4.17 & 0.88 & 0.084 & 0.084 & 1.71 & 4.2 & 7.6 & 4.10 & 1.50 & 9.78 & 44.98 & 36.12 & 18.90 \\
\hline 100 & 3.75 & 0.81 & 0.072 & 0.056 & 1.48 & 1.5 & 7.8 & 1.90 & 0.80 & 9.29 & 45.02 & 31.31 & 23.67 \\
\hline
\end{tabular}

Source: Soil profile analysis

6. Humic - Ferralsols (FRhu): This soil type was located in Noongluong, Thungkhe, Hangkia, Paco communes with area of 8,165.87 ha. Normally, it was distributed at high and different slopes with high elevation $(>900 \mathrm{~m})$. The results of analysis show that the soil reaction was very strong acid with soil $\mathrm{pH}_{\mathrm{kcl}}$ values of 4.60 to 4.90 . The soil was characterized by its texture ranging from sandy loam to silty loam, the soil was medium to high in organic matter (OM: $1.75-5.5 \%$ ), the total nitrogen varied from 0.175 to $0.275 \%$, the available phosphorus varied from 6.3 to $8.4 \mathrm{mg} / 100 \mathrm{~g}$ soil and the available potassium from 4.8 to $5.5 \mathrm{mg} / 100 \mathrm{~g}$ soil. Exchange cations were at low level ranging $<2 \mathrm{meq} / 100 \mathrm{~g}$ soil with $\mathrm{Ca}^{++}$and $\mathrm{Mg}^{++}$. Thus, this soil type was high for organic matter, medium to high for phosphorus and poor for potassium.

Table 4.9 Results of soil profile analysis of Humic - Acrisols

\begin{tabular}{|c|c|c|c|c|c|c|c|c|c|c|c|c|c|}
\hline \multirow{2}{*}{$\begin{array}{l}\text { Depth } \\
(\mathrm{cm})\end{array}$} & \multirow{2}{*}{$\begin{array}{l}\mathrm{pH} \\
\mathrm{kcl}\end{array}$} & \multirow{2}{*}{$\begin{array}{l}\mathrm{OM} \\
(\%)\end{array}$} & \multicolumn{3}{|c|}{ Total $(\%)$} & \multicolumn{2}{|c|}{$\begin{array}{c}\text { Available } \\
\text { (mg/100g } \\
\text { soil) }\end{array}$} & \multicolumn{3}{|c|}{$\begin{array}{l}\text { Exchange Cation } \\
\text { (meq mg/100g soil) }\end{array}$} & \multicolumn{3}{|c|}{ Soil texture $(\%) ; \mathrm{mm}$} \\
\hline & & & $\mathrm{N}$ & $\mathrm{P}_{2} \mathrm{O}_{5}$ & $\mathrm{~K}_{2} \mathrm{O}$ & $\mathrm{P}_{2} \mathrm{O}_{5}$ & $\mathrm{~K}_{2} \mathrm{O}$ & $\mathrm{Ca}^{++}$ & $\mathrm{Mg}^{++}$ & CEC & $\begin{array}{c}2- \\
0.02\end{array}$ & $\begin{array}{l}0.02- \\
0.002\end{array}$ & $<0.002$ \\
\hline $0-24$ & 4.60 & 5.50 & 0.275 & 0.145 & 0.90 & 8.4 & 5.5 & 1.34 & 0.45 & 12.13 & 67.6 & 18.5 & 13.9 \\
\hline $\begin{array}{c}24- \\
38\end{array}$ & 4.90 & 2.10 & 0.150 & 0.120 & 0.86 & 6.3 & 4.8 & 1.28 & 0.34 & 10.18 & 61.2 & 19.3 & 19.5 \\
\hline $\begin{array}{c}38- \\
72\end{array}$ & 4.80 & 1.75 & 0.100 & 0.110 & 0.85 & 6.5 & 4.8 & 1.25 & 0.34 & 10.05 & 61.1 & 19.2 & 19.7 \\
\hline
\end{tabular}

Source: Soil profile analysis 


\subsubsection{Soil texture}

The soil texture criterion is a basic soil physical parameter (Gorsevski et al., 2006) possibly used for determining landslide susceptibility. Soil texture relates directly to soil cohesion. The smaller soil particles are, the higher soil cohesive characteristic it is. Also based on the result of soil map of Maichau District made by the Institute of Agricultural Planning in 1999, soil texture was divided into three categories including: sandy loam, silty loam and clay loam.

Table 4.10 Categories of soil texture in Maichau District - Hoabinh Province

\begin{tabular}{ccccc}
\hline No & $\begin{array}{c}\text { Categories of soil } \\
\text { texture }\end{array}$ & Notation & Area (ha) & Proportion (\%) \\
\hline 1 & Sandy loam & $\mathrm{L}_{1}$ & $23,624.88$ & 43.01 \\
2 & Silty loam & $\mathrm{L}_{2}$ & $7,017.10$ & 12.77 \\
3 & Clay loam & $\mathrm{L}_{3}$ & $24,286.69$ & 44.21 \\
\hline & Total & & $54,928.67$ & 100.00 \\
\hline
\end{tabular}

Source: Anonymous (1999)

The table 4.10 shows that clay loam had 24,287 ha, equivalent to around $44 \%$ of the total district, it is sitting at the highest proportion. It was mainly distributed in Hangkia, Paco, Nameo, Thungkhe, Bakhan, Longluong, Pupin communes. Standing in second was sandy loam with $43 \%$ of the total research area situated in Tanmai, Phucsan, Tandan, Tanson, Piengve, Cunpheo communes. The lowest proportion was silty loam with only $13 \%$ of the district, it was distributed in the middle of the district including some communes like: Maihich, Samkhoe, Chiengchau, Tongdau Communes and Maichau Town.

\subsubsection{Soil depth}

It is widely recognized that geology greatly influences the landslides. Permeability of rocks and soils affect significantly landslide happening (Ayalew \& Yamagishi, 2005). Soil depth can cause the landslides because of its ability to store water inside the land (Gorsevski et al., 2006). As soil depth is one of the most crucial parameters in deterministic landslide 
hazard assessment, the use of shallow geophysics should receive more attention (Sidle \& Ochiai, 2006: p59-63; Westen et al., 2006). There were four categories of soil depth resulted by the Institute of Agricultural Planning in 1999, as follows: $>100 \mathrm{~cm}, 70 \mathrm{~cm}-$ $100 \mathrm{~cm}, 50 \mathrm{~cm}-70 \mathrm{~cm}$ and $<50 \mathrm{~cm}$.

Table 4.11 Categories of soil depth in Maichau District - Hoabinh Province

\begin{tabular}{ccccc}
\hline No & $\begin{array}{c}\text { Categories of soil } \\
\text { depth }\end{array}$ & Notation & Area (ha) & Proportion (\%) \\
\hline 1 & $>100 \mathrm{~cm}$ & $\mathrm{D}_{1}$ & $3,414.62$ & 6.22 \\
2 & $70 \mathrm{~cm}-100 \mathrm{~cm}$ & $\mathrm{D}_{2}$ & $6,558.88$ & 11.94 \\
3 & $50 \mathrm{~cm}-70 \mathrm{~cm}$ & $\mathrm{D}_{3}$ & $22,741.44$ & 41.44 \\
4 & $<50 \mathrm{~cm}$ & $\mathrm{D}_{4}$ & $22,213.73$ & 40.44 \\
\hline & Total & & $54,928.67$ & 100.00 \\
\hline
\end{tabular}

Source: Anonymous (1999)

The table shows that most of the research area had soil depth of $<70 \mathrm{~cm}(82 \%$ area of the total district). The soil depth, generally, was thin and distributed at the high slope areas. It is estimated that the ability of storing water in land is limited, leading to high potential landslides (Sidle \& Ochiai, 2006: p130). However, 6.2\% of the total area with around 3,415 ha was thick with $>100 \mathrm{~cm}$ and situated at low slope. Obviously, this area is suitable for agricultural activities. Soil depth from $70-100 \mathrm{~cm}$ accounted for about $12 \%$ with roughly 6,559 ha, mainly distributed in the low hills.

\subsubsection{Vegetation cover}

Vegetation cover is one of the dynamic factors that are influenced mostly by frequency and magnitude of the events (Gorsevski et al., 2006; Sidle \& Ochiai, 2006: p163) such as human activities. According to Sidle and Ochiai (2006), land use activities and concentrated disturbances affect the magnitude, frequency and type of landslides that occur in many parts of the world. Therefore, it is an important factor that directly affects landslides. In Vietnam, land inventory has been carried out every five years, beginning in 1990, 1995, 2000, 2005, 2010. It has been funded by government and helped by different institutes, universities and specific companies. The results of land inventory are land use 
types, vegetation cover and land for other purposes.

Purposes of land inventory: According to Directive No 24 (1999), Directive No 618 (2009), Official dispatch (1999), Anonymous (2010e: p1-2) :

- To identify the current status of the natural area of administrative units, status of land use under administrative management, used and unused land resource and bare land resource;

- To inventory the area of each Land Use Type (LUT) such as: agriculture, forest, residential area, infrastructure and spare land areas. And to do the inventory of land users, following: households, organizations, and communities for each LUT;

- To show and record the results of land inventory on the current land use map and tables of land use. And they will be recorded on the paper and digital files.

Land inventory is synchronously carried out from communal to national level. District and provincial are the intermediate level. Particularly, in communal level, land inventory is conducted on each household and each pilot of land. The map scale of the land inventory in Vietnam (Circular No 08, 2007; Directive No 24, 1999; Directive No 618, 2009; Official dispatch, 1999) is shown in table 4.12. The accuracy at the village and communal level is the highest and it is carried out at each pilot of household's land for inventorying land use types, and area. When doing the field trip, a map with the highest accuracy is used (normally scale of 1:1000) to ensure the highest level of accuracy. 


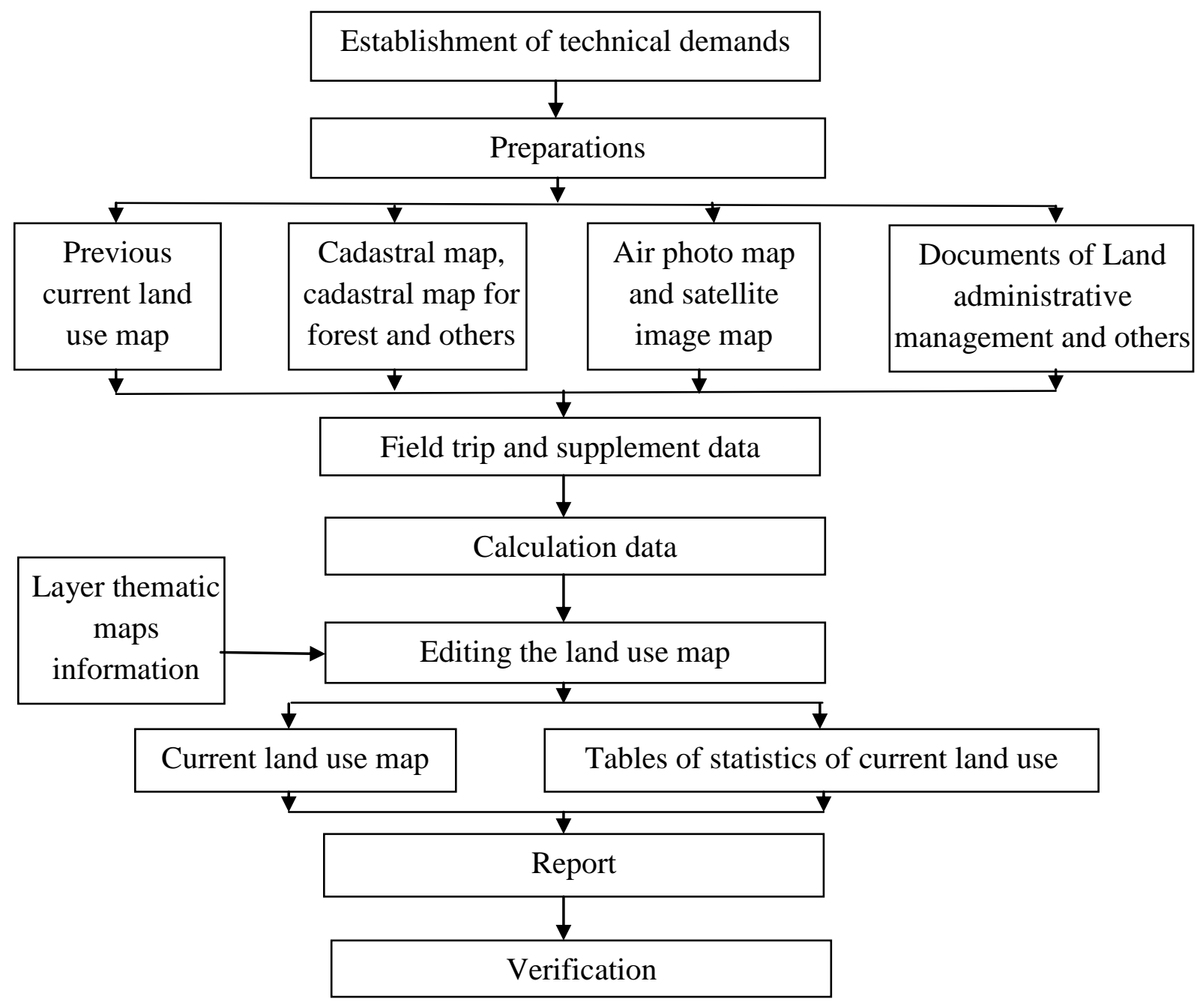

Fig.4.5 Process of land inventory in Vietnam Source: Anonymous (2010e: p13)

Land use types in district, provincial and national level are synthesized from the communal, district and provincial level, respectively (Anonymous, 2010e: p10-11; Official dispatch, 1999). The ground map used to draw is an air photo map, so that the accuracy is as high as possible. The district, provincial and national level usually use satellite image maps as reference documents. In the urban area, map scale 1:500 is used to make an inventory of residential land (Anonymous, 2010e). The results of land inventory are official and legal documents and are widely used in every branch. 
Table 4.12 Step and map scale of land use inventory in Vietnam

\begin{tabular}{cll}
\hline Step & Level & \multicolumn{1}{c}{ Scale of map } \\
\hline Step 1 & Village & $1 / 1000$ for agriculture and resident \\
& & area in rural region. \\
& $1 / 2000$ for forestry \\
& & \\
& Commune & $1 / 500$ for resident area in the city \\
& District & $1 / 5,000$ \\
Step 2 & & $1 / 10,000$ \\
& Province & and $1 / 25,000$ \\
Step 3 & & $1 / 50,000$ \\
& National & and $1 / 100,000$ \\
Step 4 & & $1 / 1,000,000$ \\
\hline
\end{tabular}

Sources: Decision 20 (2007), Official dispatch (1999)

Land inventory in Maichau District was carried out in the whole district from January to September in 2000. The results are shown in table 4.13 and fig.4.5.

Table 4.13 Categories of vegetation cover in Maichau District - Hoabinh Province

\begin{tabular}{clccc}
\hline No & \multicolumn{1}{c}{$\begin{array}{c}\text { Categories of } \\
\text { vegetation cover }\end{array}$} & Notation & Area (ha) & Proportion (\%) \\
& Forest & $\mathrm{V}_{1}$ & $38,774.16$ & 70.59 \\
\hline 1 & Perennial tree & $\mathrm{V}_{2}$ & $2,084.85$ & 3.80 \\
3 & Agriculture & $\mathrm{V}_{3}$ & $4,341.47$ & 7.90 \\
4 & Shrubs and treeless & $\mathrm{V}_{4}$ & $9,728.19$ & 17.71 \\
& hill & & & \\
\hline & Total & $54,928.67$ & 100.00 \\
\hline
\end{tabular}

Source: Anonymous (2000)

The data shows that around $71 \%$ area of the district was coved by forest that was 
distributed in all communes. Most of the forest area was planted bamboo and it was estimated that bamboo brought a higher income in comparison with other trees (Anonymous, 2001: p30). Following was shrubs and treeless hill (relation to unused land) with roughly $18 \%$ of the total area, equivalent to 9,728 ha. This area had related to deforestation in 80's and lack of capital in the district (Anonymous, 2001: p40; Cuong, 2005a: p180). Obviously, shrubs and treeless hill possibly trigger landslide with the highest probability. Agricultural area accounted for $8 \%$, and was distributed mostly at low slope. The lowest proportion was perennial tree with only $4 \%$, and situated in the low terrain. 


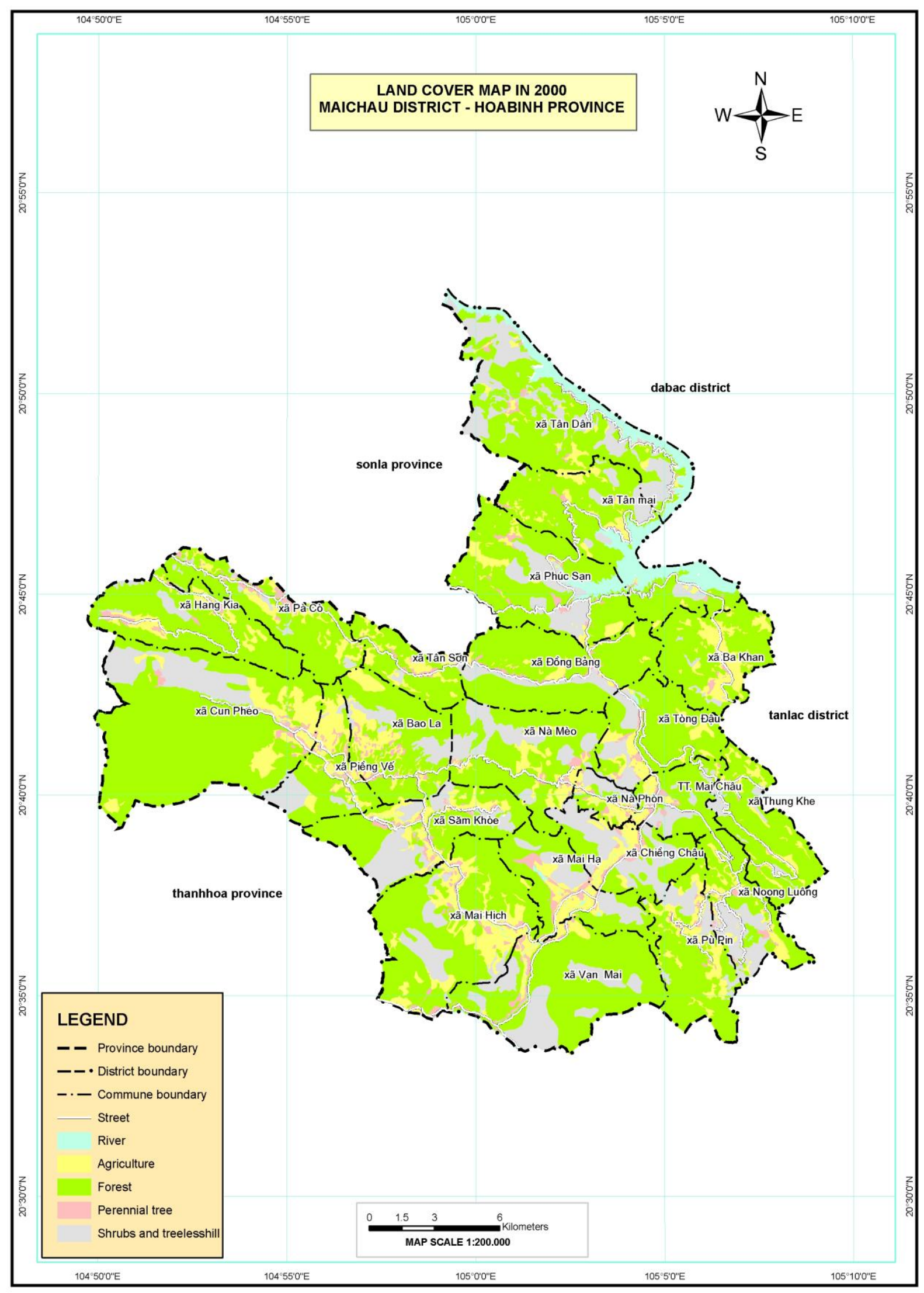

Fig.4.6 Vegetation cover in 2000 in Maichau District; Source: Anonymous (2000) 


\subsubsection{Weight of criteria to determine landslide susceptibility}

\subsubsection{Pair-wise comparison}

The hierarchy structure to determine landslide susceptibility in Maichau District was established as show in Fig. 4.7. Level one had the main criteria: Slope, soil type, soil texture, soil depth and vegetation cover. Level two had sub-criteria: four categories of slope, six categories of soil type, three categories of soil texture, four categories of soil depth and four categories of vegetation cover. The value of pair-wise comparison was specified by quality, equity of each criterion, sub-criterion for landslide susceptibility. The reciprocal matrix was used to compare two criteria in one pair-wise comparison and it was repeated to the last criterion in the level one. For level two, sub-criteria in each main criterion were reciprocally compared to determine weight of each sub-criterion.

Experts and experience of some officials in the district were consulted to determine the value of each pair-wise comparison for landslide susceptibility. Indeed, the fundamental scale values in the comparison matrix were determined by consultancy of experts at the Department of Land Use Planning, the Department of Soil Science, the Department of Water Resource (belong to HUA), and by some officials at the Department of Natural Resources Management and Environment of Maichau District and Hoabinh Province, and by some natural resources officials in communes of the district (detail in section 4.3.1). The results are shown in table 4.14 for level one and table 4.15-4.19 for level two. 


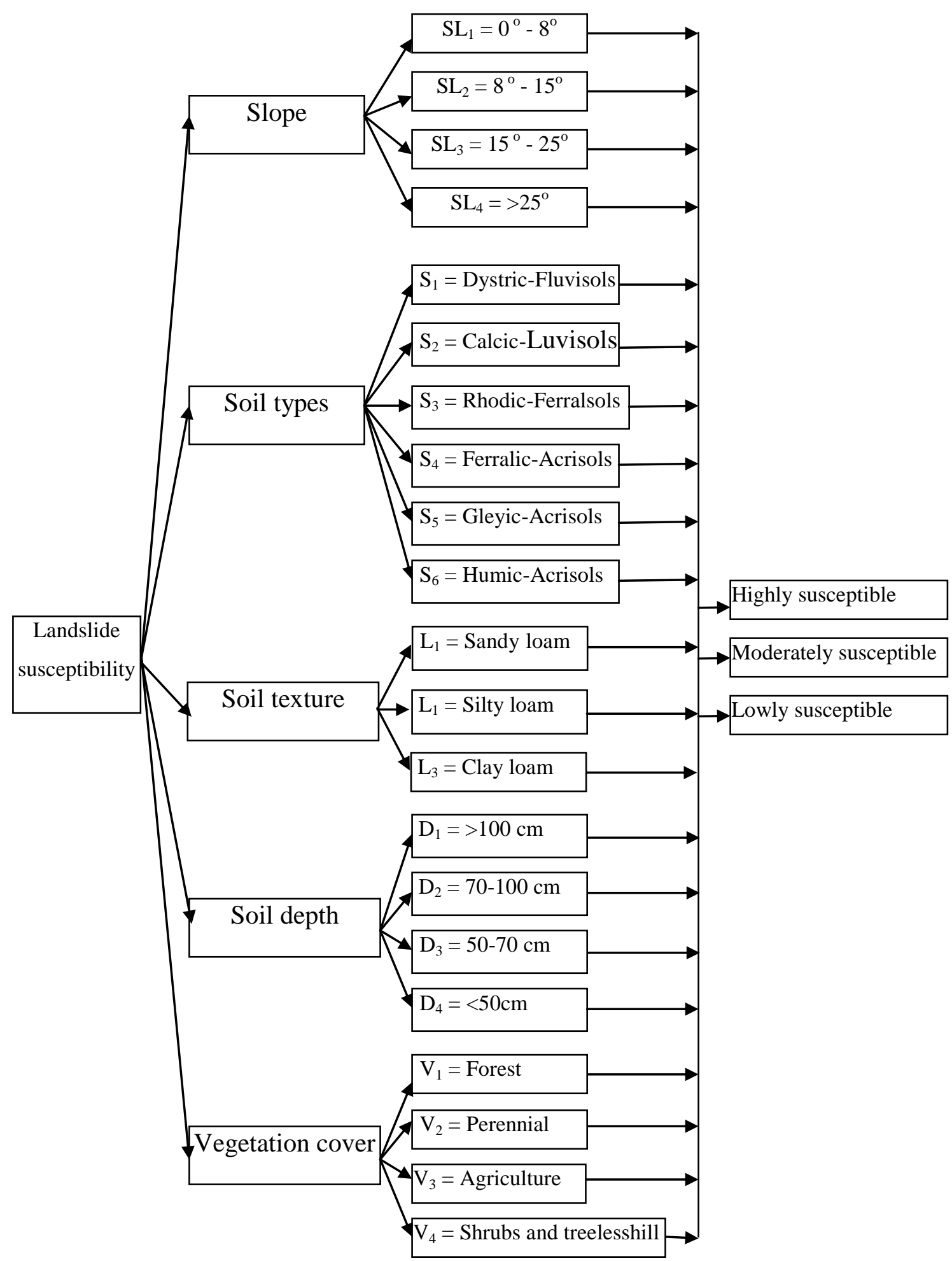

Fig.4.7 Hierarchy structure to determine landslide susceptibility in Maichau District 
Table 4.14 Pair-wise comparison of criteria level one

\begin{tabular}{lccccc}
\hline \multicolumn{1}{c}{ Criteria } & $\begin{array}{c}\text { Slope } \\
(\mathrm{SL})\end{array}$ & $\begin{array}{c}\text { Soil types } \\
(\mathrm{S})\end{array}$ & $\begin{array}{c}\text { Soil texture } \\
(\mathrm{L})\end{array}$ & $\begin{array}{c}\text { Soil depth } \\
(\mathrm{D})\end{array}$ & $\begin{array}{c}\text { Vegetation } \\
\text { cover (V) }\end{array}$ \\
\hline Slope (SL) & 1 & 3 & 4 & 6 & 1 \\
Soil types (S) & $1 / 3$ & 1 & 1 & 3 & $1 / 2$ \\
Soil texture (L) & $1 / 4$ & 1 & 1 & 2 & $1 / 3$ \\
Soil depth (D) & $1 / 6$ & $1 / 3$ & $1 / 2$ & 1 & $1 / 5$ \\
Vegetation & 1 & 2 & 3 & 5 & 1 \\
cover (V) & & & & & \\
\hline
\end{tabular}

Table 4.15 Pair-wise comparison of sub-criteria of slope (level two)

\begin{tabular}{lcccc}
\hline \multicolumn{1}{c}{ Sub-criteria } & $\mathrm{SL}_{1}: 0-8^{\mathrm{o}}$ & $\mathrm{SL}_{2}: 8-15^{\mathrm{o}}$ & $\mathrm{SL}_{3}: 15-25^{\mathrm{o}}$ & $\mathrm{SL}_{4}:>25^{\mathrm{o}}$ \\
\hline $\mathrm{SL}_{1}: 0-8^{\mathrm{o}}$ & 1 & $1 / 2$ & $1 / 4$ & $1 / 6$ \\
$\mathrm{SL}_{2}: 8-15^{\mathrm{o}}$ & 2 & 1 & $1 / 2$ & $1 / 4$ \\
$\mathrm{SL}_{3}: 15-25^{\mathrm{o}}$ & 4 & 2 & 1 & $1 / 2$ \\
$\mathrm{SL}_{4}:>25^{\circ}$ & 6 & 4 & 2 & 1 \\
\hline
\end{tabular}

Table 4.16 Pair-wise comparison of sub-criteria of soil types (level two)

\begin{tabular}{lcccccc}
\hline \multicolumn{1}{c}{ Sub-criteria } & $\mathrm{S}_{1}$ & $\mathrm{~S}_{2}$ & $\mathrm{~S}_{3}$ & $\mathrm{~S}_{4}$ & $\mathrm{~S}_{5}$ & $\mathrm{~S}_{6}$ \\
\hline $\mathrm{S}_{1}$ : Dystric-Fluvisols & 1 & 2 & 6 & 3 & 1 & 4 \\
$\mathrm{~S}_{2}$ : Calcic- Luvisols & $1 / 2$ & 1 & 4 & 1 & $1 / 3$ & 2 \\
$\mathrm{~S}_{3}$ : Rhodic- Ferrasols & $1 / 6$ & $1 / 4$ & 1 & $1 / 3$ & $1 / 7$ & 2 \\
$\mathrm{~S}_{4}$ : Ferralic-Acrisols & $1 / 3$ & 1 & 3 & 1 & $1 / 4$ & 1 \\
$\mathrm{~S}_{5}$ : Gleyic- Acrisols & 1 & 3 & 7 & 4 & 1 & 5 \\
$\mathrm{~S}_{6}$ : Humic- Acrisols & $1 / 4$ & $1 / 2$ & $1 / 2$ & 1 & $1 / 5$ & 1 \\
\hline
\end{tabular}


Table 4.17 Pair-wise comparison of sub-criteria of soil depth (level two)

\begin{tabular}{lcccc}
\hline \multicolumn{1}{c}{ Sub-criteria } & $\mathrm{D}_{1}:>100 \mathrm{~cm}$ & $\mathrm{D}_{2}: 70-100 \mathrm{~cm}$ & $\mathrm{D}_{3}: 50-70 \mathrm{~cm}$ & $\mathrm{D}_{4}:<50 \mathrm{~cm}$ \\
\hline $\mathrm{D}_{1}:>100 \mathrm{~cm}$ & 1 & $1 / 2$ & $1 / 4$ & $1 / 6$ \\
$\mathrm{D}_{2}: 70-100 \mathrm{~cm}$ & 2 & 1 & $1 / 2$ & $1 / 4$ \\
$\mathrm{D}_{3}: 50-70 \mathrm{~cm}$ & 4 & 2 & 1 & $1 / 2$ \\
$\mathrm{D}_{4}:<50 \mathrm{~cm}$ & 6 & 4 & 2 & 1 \\
\hline
\end{tabular}

Table 4.18 Pair-wise comparison of sub-criteria of soil texture (level two)

\begin{tabular}{lccc}
\hline Sub-criteria & $\mathrm{L}_{1}$ : Sandy loam & $\mathrm{L}_{2}:$ Silty loam & $\mathrm{L}_{3}$ : Clay loam \\
\hline $\mathrm{L}_{1}$ : Sandy loam & 1 & 4 & 6 \\
$\mathrm{~L}_{2}$ : Silty loam & $1 / 4$ & 1 & 2 \\
$\mathrm{~L}_{3}$ : Clay loam & $1 / 6$ & $1 / 2$ & 1 \\
\hline
\end{tabular}

Table 4.19 Pair-wise comparison of sub-criteria of vegetation cover (level two)

\begin{tabular}{lcccc}
\hline \multicolumn{1}{c}{ Sub-criteria } & $\mathrm{V}_{1}$ : Forest & $\begin{array}{c}\mathrm{V}_{2} \text { : Perennial } \\
\text { tree }\end{array}$ & $\mathrm{V}_{3}$ : Agriculture & $\begin{array}{c}\mathrm{V}_{4} \text { : Shrubs and } \\
\text { treelesshill }\end{array}$ \\
\hline $\mathrm{V}_{1}$ : Forest & 1 & $1 / 2$ & $1 / 4$ & $1 / 6$ \\
$\mathrm{~V}_{2}$ : Perennial tree & 2 & 1 & $1 / 2$ & $1 / 4$ \\
$\mathrm{~V}_{3}$ : Agriculture & 4 & 2 & 1 & 2 \\
$\mathrm{~V}_{4}$ : Shrubs and & 6 & 4 & $1 / 2$ & 1 \\
treeless hill & & & & \\
\hline
\end{tabular}

The tables indicate that the difference between two criteria in each pair-wise comparison is from 1 to 7 in comparison with the fundamental scale from 1-9.

\subsubsection{Weight of criteria}

By the help of software Expert Choice 11.5, the weight of each criterion was calculated. The results show the priority of each criterion with the respect to landslide susceptibility in Maichau District. The weights are shown in table 4.20. 
Table 4.20 Weight of criteria to determine landslide susceptibility in Maichau District

\begin{tabular}{|c|c|c|c|c|}
\hline \multicolumn{2}{|c|}{ Level one } & \multicolumn{2}{|l|}{ Level two } & \multirow{2}{*}{ Final weight } \\
\hline Criteria & Weight & Sub-criteria & Weight & \\
\hline \multirow{4}{*}{1 Slope } & \multirow{4}{*}{0.376} & 1. $\mathrm{SL}_{1}: 0-8^{\circ}$ & 0.074 & 0.028 \\
\hline & & 2. $\mathrm{SL}_{2}: 8-15^{\circ}$ & 0.138 & 0.052 \\
\hline & & 3. $\mathrm{SL}_{3}: 15-25^{\circ}$ & 0.275 & 0.103 \\
\hline & & 4. $\mathrm{SL}_{4}:>25^{\circ}$ & 0.513 & 0.193 \\
\hline \multirow{6}{*}{ 2. Soil types } & \multirow{6}{*}{0.140} & 1. $S_{1}$ : Dystric-Fluvisols (FLd) & 0.293 & 0.041 \\
\hline & & 2. $\mathrm{S}_{2}$ : Calcic- Luvisols (LVca) & 0.135 & 0.019 \\
\hline & & 3. $\mathrm{S}_{3}$ : Rhodic - Ferrasols (FRr) & 0.041 & 0.006 \\
\hline & & 4. $\mathrm{S}_{4}$ : Ferralic - Acrisols (ACf) & 0.103 & 0.014 \\
\hline & & 5. $\mathrm{S}_{5}$ : Gleyic - Acrisols (ACg) & 0.351 & 0.049 \\
\hline & & 6. $S_{6}:$ Humic - Ferrasols (FRhu) & 0.078 & 0.011 \\
\hline \multirow{3}{*}{ 3. Soil texture } & \multirow{3}{*}{0.112} & $\mathrm{~L}_{1}$ : Sandy loam & 0.701 & 0.079 \\
\hline & & $\mathrm{L}_{2}$ : Silty loam & 0.193 & 0.022 \\
\hline & & $\mathrm{L}_{3}:$ Clay loam & 0.106 & 0.012 \\
\hline \multirow{4}{*}{ 4. Soil depth } & \multirow{4}{*}{0.057} & $\mathrm{D}_{1}:>100 \mathrm{~cm}$ & 0.074 & 0.004 \\
\hline & & $\mathrm{D}_{2}: 70-100 \mathrm{~cm}$ & 0.138 & 0.008 \\
\hline & & $\mathrm{D}_{3}: 50-70 \mathrm{~cm}$ & 0.275 & 0.016 \\
\hline & & $\mathrm{D}_{4}:<50 \mathrm{~cm}$ & 0.513 & 0.029 \\
\hline \multirow{4}{*}{$\begin{array}{l}5 . \text { Vegetation } \\
\text { cover }\end{array}$} & \multirow{4}{*}{0.315} & $\mathrm{~V}_{1}$ : Forest & 0.074 & 0.023 \\
\hline & & $\mathrm{V}_{2}$ : Perennial tree & 0.138 & 0.043 \\
\hline & & $\mathrm{V}_{3}$ : Agriculture & 0.275 & 0.087 \\
\hline & & $\mathrm{V}_{4}$ : Shrubs and treeless hill & 0.513 & 0.162 \\
\hline
\end{tabular}

Source: Own calculation

The table shows that in level one, weight of slope is the highest with 0.376, after that vegetation cover with 0.315 . The lowest weight is soil depth with only 0.057 . The higher weights in comparison with the lowest one are soil type and soil texture with 0.14 and 
0.112, respectively. Similarly, in level two, sub-criteria were valuated with respect to landslide susceptibility. The higher weight of each sub-criterion reflects the greater role in causing the landslides in the district.

After valuating level one and level two, the final weight $\left(\mathrm{W}_{\mathrm{fl}}\right)$ of each sub-criterion with respect to landslide susceptibility in comparison with all criteria was determined. Formula was used to calculate the final weight of each criterion.

$$
\mathrm{W}_{\mathrm{fl}}=\mathrm{W}_{1} * \mathrm{~W}_{2}
$$

where: $\mathrm{W}_{1}$ : weight of level one;

$\mathrm{W}_{2}$ : weight of level two.

The results show that sub-criterion of slope $>25^{\circ}$ has the highest weight with 0.193 , so it is the most important criterion possibly causing the landslide. After that, sub-criterion of shrubs and treeless hill is the second place with the weight of 0.162 . The lowest weights are soil depth $>100 \mathrm{~cm}$ and soil type Rhodic-Ferrasols with 0.004 and 0.006 , respectively. Other weights range mostly from 0.087 to 0.011 . Based on the final weight of each criterion, zoning the landslide susceptibility will be carried out in the following section.

\subsubsection{Zoning the landslide susceptibility}

The range weight is basically defined as a numerical range. It is used to determine that whether an assessed factor is in the range weight or not. The range weight can be used with the numbers from 0 to 1 , or 1 to 100, for example: land suitability (Baniya, 2008; Loi, 2008: p154; Store \& Jokimäki, 2003); suitability of potential sites for greenway development (Miller et al., 1998). The range weight of landslide susceptibility is understood as a susceptible range that a pixel of a map could have.

Actually, the range weight of each landslide susceptibility classification was determined by AHP method. The fundamental scale values between three categories of landslide susceptibility were selected by own intuition based on the opinion of experts (for more detail, see section 4.3.1). The comparison matrix is shown in table 4.21. Expert Choice 11.5 was as well used to specify the range weight in the research area based on the values 
documented in table 4.21. The resulting range weight classification for the three susceptibility classes are shown in table 4.22. As with any step in the AHP process, the classification directly reflects analyst choices based on his/her judgment.

Table 4.21 Pair-wise comparison of landslide susceptibility classification

\begin{tabular}{lccc}
\hline \multicolumn{1}{c}{ Classification } & High susceptibility & Moderate susceptibility & Low susceptibility \\
\hline High susceptibility & 1 & 3 & 6 \\
Moderate susceptibility & $1 / 3$ & 1 & 3 \\
Low susceptibility & $1 / 6$ & $1 / 3$ & 1 \\
\hline
\end{tabular}

Table 4.22 Landslide susceptibility classification

Classification of Range $\quad$ Classification
weight

$\begin{array}{lll}>0.250 & \text { Highly susceptible } & \begin{array}{l}\text { Almost all criteria set out for high } \\ \text { susceptibility are met }\end{array} \\ & \text { Moderately } & \text { Meet several criteria set out for } \\ & \text { susceptibility, but some limits of } \\ & \text { susceptible } & \text { some criteria } \\ & & \\ & \text { Meet almost all criteria set out for } \\ & \text { Lowly susceptible } & \text { low susceptibility, but some criteria } \\ & \text { may be compromised to a minor }\end{array}$

The table indicates that a pixel with five criteria overlapped having range weight $>0.250$ is judged as highly susceptible, for $0.095-0.250$ as moderately susceptible, and for $<0.095$ as lowly susceptible.

Total weight of each pixel was calculated based on the formula: 


$$
\mathrm{W}_{\text {pixel }}=\sum_{i=1}^{n} W_{i}
$$

where: $\mathrm{W}_{\text {pixel }}$ : Weight of each pixel

$\mathrm{W}_{\mathrm{i}}$ : Final weight of $\mathrm{i}^{\text {th }}$ criterion.

n: Number of criterion.

GIS software (ArcGIS 9.3) was applied to overlap the thematic maps including soil map, slope map, soil texture, soil depth and vegetation cover to build the map of landslide susceptibility in Maichau District.

\subsection{Results}

With the help of GIS application (ArcGIS 9.3), the overlapping of different thematic maps, including: soil type, slope, soil texture, soil depth, and vegetation cover maps, was carried out. The area of the three categories of landslide susceptibility, as follows: low, moderate and high shown in appendix 1, fig.4.8 and fig.4.9 was calculated automatically by each pixel.

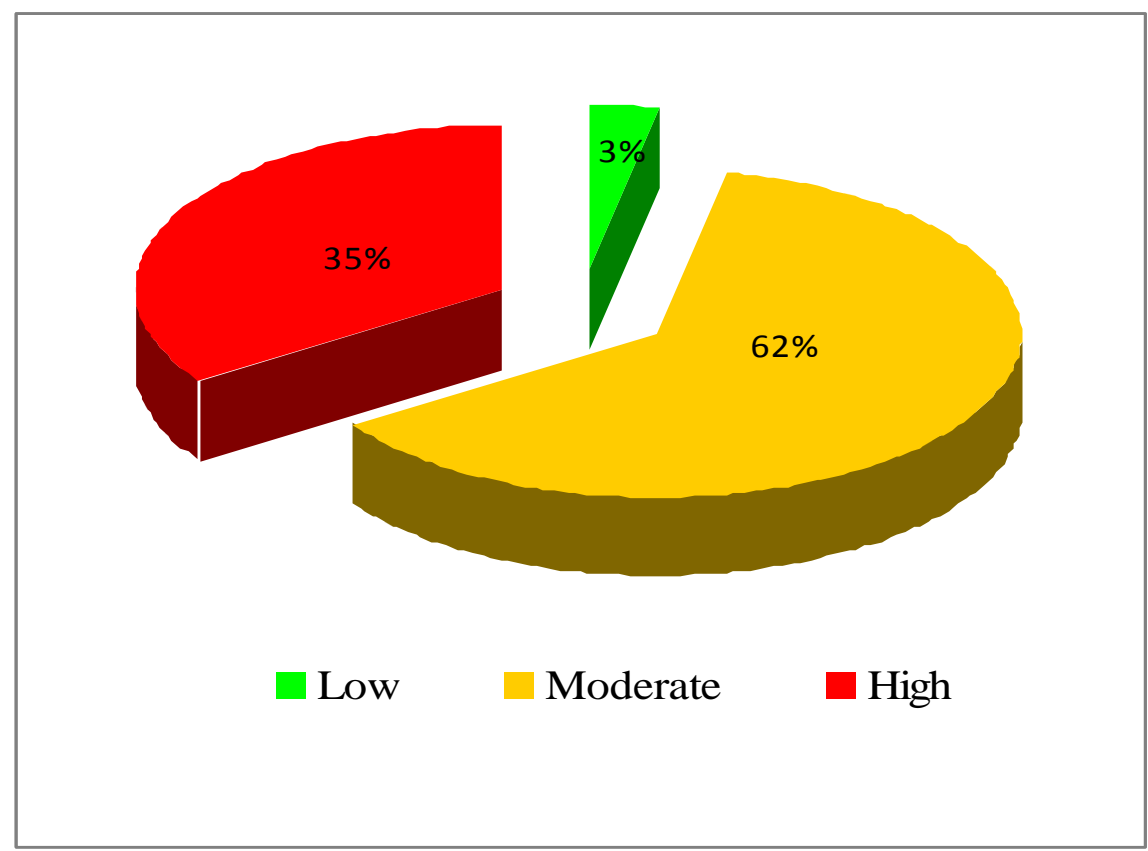

Fig.4.8 Landslide susceptibility in Maichau (Pie Chart) 


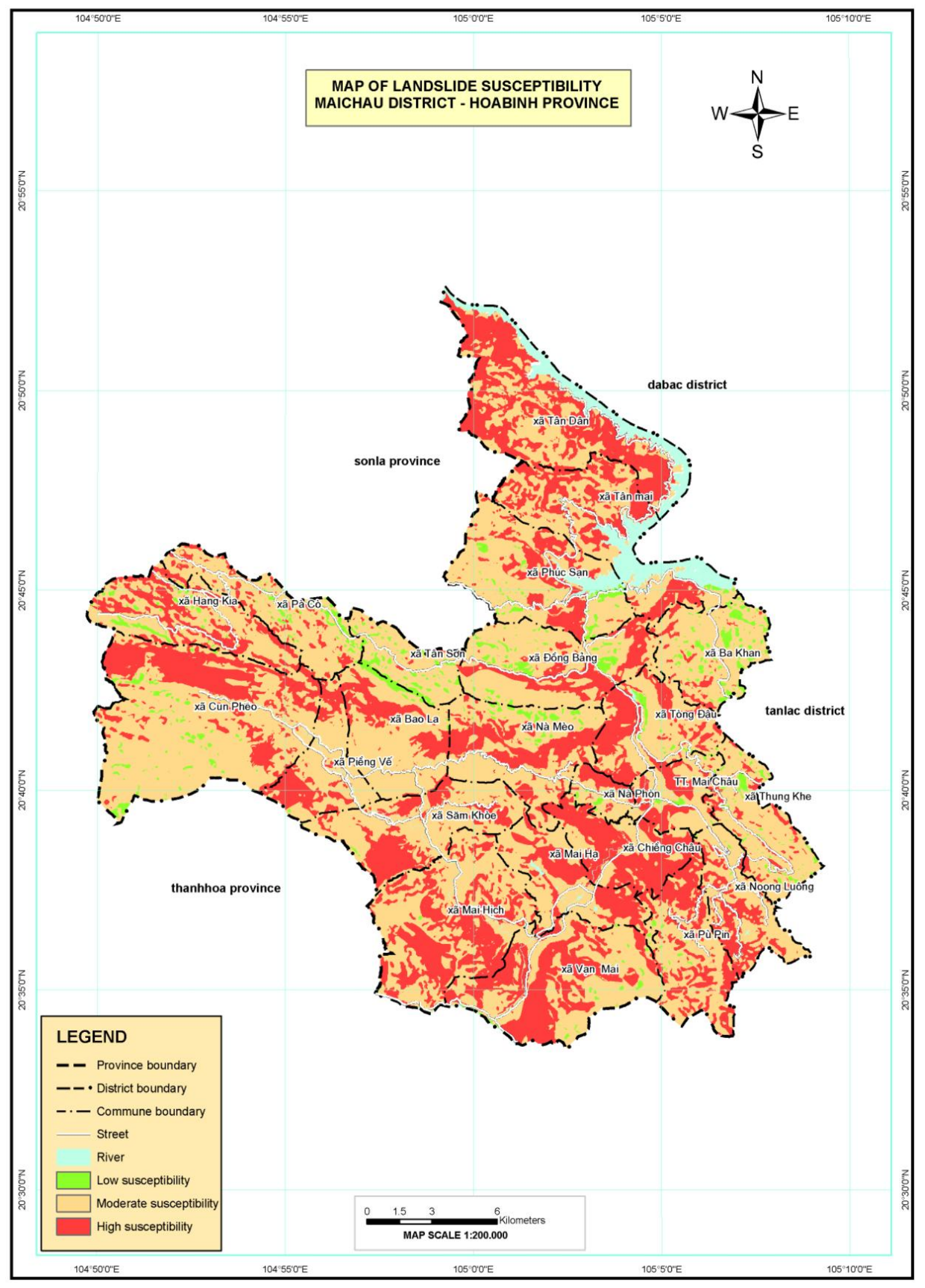

Fig.4.9 Map of landslide susceptibility in Maichau District 
The data in appendix 1 and fig. 4.8 shows that roughly 3\% area of the total district was predicted as low susceptibility. Averagely, area of low susceptibility was divided into each commune with around 2-5\%. However, these areas in some communes, such as: Tandan, Chiengchau, Maihich, were very small with zero ha, 0.23 ha and 2.83 ha, respectively. In particular, the largest area was found in Bakhan with 234 ha. After that, Dongbang, Tanson, Cumpheo communes stood at the lower positions with 190 ha, 178 ha and 178 ha, respectively.

Area of moderate susceptibility occupied about $62 \%$ of the district. The area accounted for $50-70 \%$ area of each commune. The highest positions were Tanson with nearly $82 \%$. Standing at the lower position was Thungkhe, Bakhan, Paco communes with roughly 80\%, $80 \%$ and $77 \%$, respectively. The lowest position was Chiengchau with only $30 \%$ of the commune. Standing at the second and the third lowest position was Tandan and Vanmai with $37 \%$ and $55 \%$ of each commune.

The most important area is high susceptibility predicted in the research area. Fig.4.8 shows that this area accounted for roughly $35 \%$ and was not distributed equally in 22 communes and a town. Indeed, Tandan commune had the greatest area with 2,288 ha, accounting for $63 \%$ area of the commune. Similarly, Maihich, Cunpheo and Vanmai communes also occupied very large area of high susceptibility with 1,710 ha, 1,686 ha, and 1,578 ha, made up 43\%, 28\% and 44\% area of each commune, respectively. On the contrary, Tanson and Bakhan communes had the smallest area of high susceptibility with only 44 ha and 162 ha, accounting for about $4 \%$ and $8 \%$ area, respectively. In other communes, it occupied roughly $30-40 \%$ of each commune for high susceptibility.

\subsection{Conclusions and discussions}

AHP is regarded as a suitable method to determine landslide susceptibility and other analyses of environmental damage. One of the limitations of AHP method usually needs to be confronted with is the intuition for selecting the criteria and fundamental scale values between different criteria towards the relative overall goal. In this application of the AHP method, however, my own judgment is based not only on my own intuition but is supported by an extensive consultation process with national, regional and local experts. 
The landslide susceptibility model indicates that roughly $35 \%$ area of the whole district is judged as having a high susceptibility. However, the prediction of triggered factors also can occur some concerns. Demounlin and Chung (2007) pointed out that the predicted features may have different direct or indirect causes, one should carefully avoid omitting triggering factors of the prediction. The prediction of triggered factors needs plenty of years data (10 years or longer) not for single year because of extremely random factors like climatic conditions (chapter 2).

Because of the structure of the overall analysis, assigning a pixel to a landslide susceptibility class has far reaching consequences. The assignment, in turn, depends on the natural science data of the pixel, the analysis judgments on the relative importance of the criteria, and finally on the classification of the range weights which is itself directly based on the analyst judgments. If the landslide susceptibility map is be of help to planners and land users for choosing suitable locations to implement different development scenarios depends, foremost, on its capacity to predict actual landslides. If it turns out that the classification is overly strict or overly restricted in assigning a pixel to a "high" landslide susceptibility class, changes to the range weights of the classification can be accomplished relatively easy without having to change the basic structure of the AHP landslide susceptibility model. Adjustments may indicate if (i) the model is not able to predict actual landslides well (see chapter 5), or (ii) if the classification results in economically disadvantageous overall planning results (see chapter 5) 


\section{CHAPTER 5: INTEGRATION OF LANDSLIDE SUSCEPTIBILITY INTO LUP - AN ECONOMIC CASE STUDY IN MAICHAU DISTRICT, VIETNAM}

The objectives of this chapter are to answer the following questions: (1) How to integrate landslide susceptibility into LUP? (2) How to assess the cost and benefit of the integration? GIS applications were used to carry out the research. In addition, simple Cost-Benefit Analysis was suggested to evaluate the economic efficiency of the integration in Maichau District. The results show that $6.30 \%$ area of the district was estimated as lowly suitable or unsuitable for some land use types proposed in LUP. Besides, 122 landslide events happened from 2000 to 2010, of which roughly 77\% of their area and the number of events occurred correctly on the high level of landslide susceptibility. If the integration was conducted in 2000, the cost would be quite large in comparison with economic benefit.

\subsection{Integration of landslide susceptibility into LUP}

\subsubsection{Overview of Geographic Information System (GIS)}

Geographic Information System (GIS) is defined as a powerful tool for collecting, storing, retrieving, transforming and displaying spatial data from the real world (Burrough, 1986). It can be used in resource assessment, land evaluation and land use planning. It provides tools for data visualization, data analysis and the evaluation of scenarios as well. GIS is an integration technology that allows, encourages and expects users to bring together data from many different sources through the unifying medium of geography. The typical application of GIS is in spatial modeling which can be described simply as combining information from several images to produce a single output image. One major part of GIS is the ability to overlay various layers of spatially referenced data (Loi, 2008: p23).

Additionally, GIS is basically understood as a computer-based system of storage and a manipulation of data which is organized by area or location. This location can be identified by a grid of cells (cell-based or raster systems), or information can be stored by means of the boundaries of mapped areas, e.g. land units or administrative units (polygon-based systems). A GIS enables different kinds of information to be recalled and combined; for 
example, areas that are both suitable for export crops and within a specified distance of an all-weather road could be overlain and mapped (FAO, 1993). Furthermore, the GIS functions help in managing spatial data and visualizing the results.

Another area in which GIS is playing an increasingly important role is in landscape visualization and 'futuring' (Nath et al., 2000). GIS techniques also help to integrate between multiple data layers and spatial simulation to explore cause-effect relationships (Zinck et al., 2001). In addition, decision-making (Lloyd, 2010: p70-75), and economicenvironmental hazard analyses (Liu et al., 2007), and eco-environment analysis ( $\mathrm{Li}$ et al., 2007) were conducted by GIS. Cuong (2005a: p329) pointed out that GIS offers great opportunities to integrate the socioeconomic data and spatial data into a multidisciplinary database. According to Man (2009: p18) GIS is widely used in local and regional planning for managing, integrating, and visualizing spatial data sets.

\subsubsection{Integration of landslide susceptibility into LUP in Maichau District}

A good LUP should demand enough input data and supports for its implementation (Son et al., 2008). In Vietnam, integration of environmental factors into LUP has been limited because of policies, knowledge of planners, and especially inadequate input data (Anonymous, 2006: p36). From 2006 - 2009, with the help of Vietnam - Sweden program, the integration of some environmental factors into LUP has been experimented in three provinces and some districts. The results are the significant referent documents to planners, in particular to decision-makers in contributing a suitable process of LUP in Vietnam. The integration of landslide susceptibility into LUP is meaningful to find out some limitations of LUP which is the object of this research.

GIS was used to overlap the map of landslide susceptibility and the map of LUP, as follows: 
Layer 1

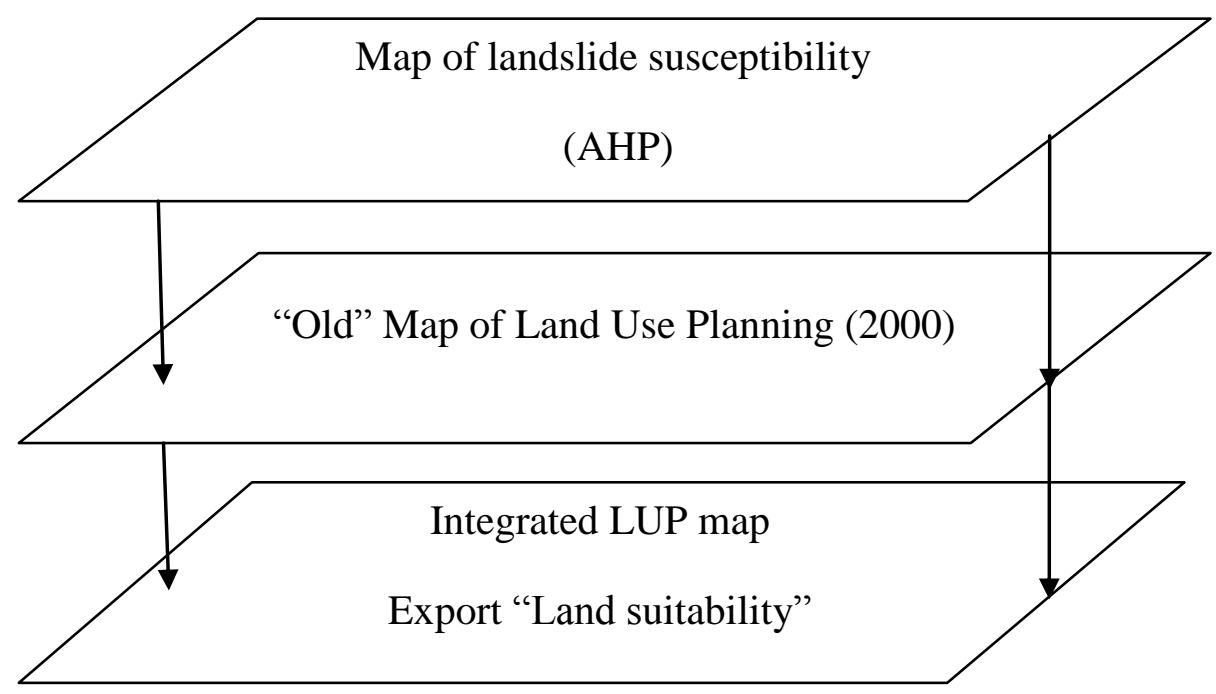

Fig.5.1 Overlapping thematic maps

Fig.5.1 shows that the overlapping was conducted on the layers, including: Map of landslide susceptibility (layer one) and map of LUP (layer two). Based on the alternatives of the integration in table 5.1, the results are shown in the integrated LUP map (layer three). 
Table 5.1 Alternatives of integration of landslide susceptibility into LUP

\begin{tabular}{|c|c|c|}
\hline $\begin{array}{l}\text { Land use planning } \\
\text { in } 2000\end{array}$ & Landslide susceptibility & Suitability rating \\
\hline \multirow{3}{*}{ Agriculture } & High susceptibility & Low suitability \\
\hline & Moderate susceptibility & Moderate suitability \\
\hline & Low susceptibility & High suitability \\
\hline \multirow{3}{*}{ Residence } & High susceptibility & Low suitability \\
\hline & Moderate susceptibility & Moderate suitability \\
\hline & Low susceptibility & Highly suitability \\
\hline \multirow{3}{*}{ Infrastructure } & High susceptibility & Low suitability \\
\hline & Moderate susceptibility & Moderate suitability \\
\hline & Low susceptibility & Highly suitability \\
\hline \multirow{3}{*}{ Forest } & High susceptibility & Moderate suitability \\
\hline & Moderate susceptibility & Moderate suitability \\
\hline & Low susceptibility & High suitability \\
\hline \multirow{3}{*}{ Unused } & High susceptibility & Low suitability \\
\hline & Moderate susceptibility & Moderate suitability \\
\hline & Low susceptibility & High suitability \\
\hline
\end{tabular}

Table 5.1 indicates that three categories were proposed in the integration, including: low, moderate and high suitability. This suitability is defined as a suitability of land use types in LUP in comparison with landslide susceptibility. Actually, LUP made in 2000 was without the landslide component, so some areas with land use types were not suitable with landslide susceptibility, even though, these areas were probably suitable for other purposes of development. Each land use type in the LUP map was overlapped with different categories of the landslide susceptibility map. Accordingly, the overlapping was carried out for different land use types, such as: agriculture, residence, infrastructure and forest. In which, only two categories of integrated LUP map were proposed for forest, including: moderate and high suitability because of the forest's ability to prevent the happening of landslide (Sidle \& Ochiai, 2006: p163).

Moreover, the integration between unused land and all three categories of landslide 
susceptibility was also conducted. This assessment based on the ability of unused land to trigger landslides. Specifically, result of overlapping between unused land and high level of landslide susceptibility was low suitability. Similarly, moderate and high suitability was result of overlapping between unused land and moderate and low levels of landslide susceptibility, respectively. These assignments based on the suitability of the location of unused land proposed in LUP to be able to trigger a landslide, actually, not on the using of this land. Indeed, low suitability means that this location of unused land in LUP was unsuitable or lowly suitable because the ability of this location to cause a landslide is the highest. Similarly, moderate and high suitability are moderately and highly suitable for these locations of unused land in LUP to trigger a landslide.

\subsubsection{Results of the integration}

ArcGis 9.3 was used to overlap layer one and layer two. The results are shown in appendix 2, fig 5.2 and fig 5.3 .

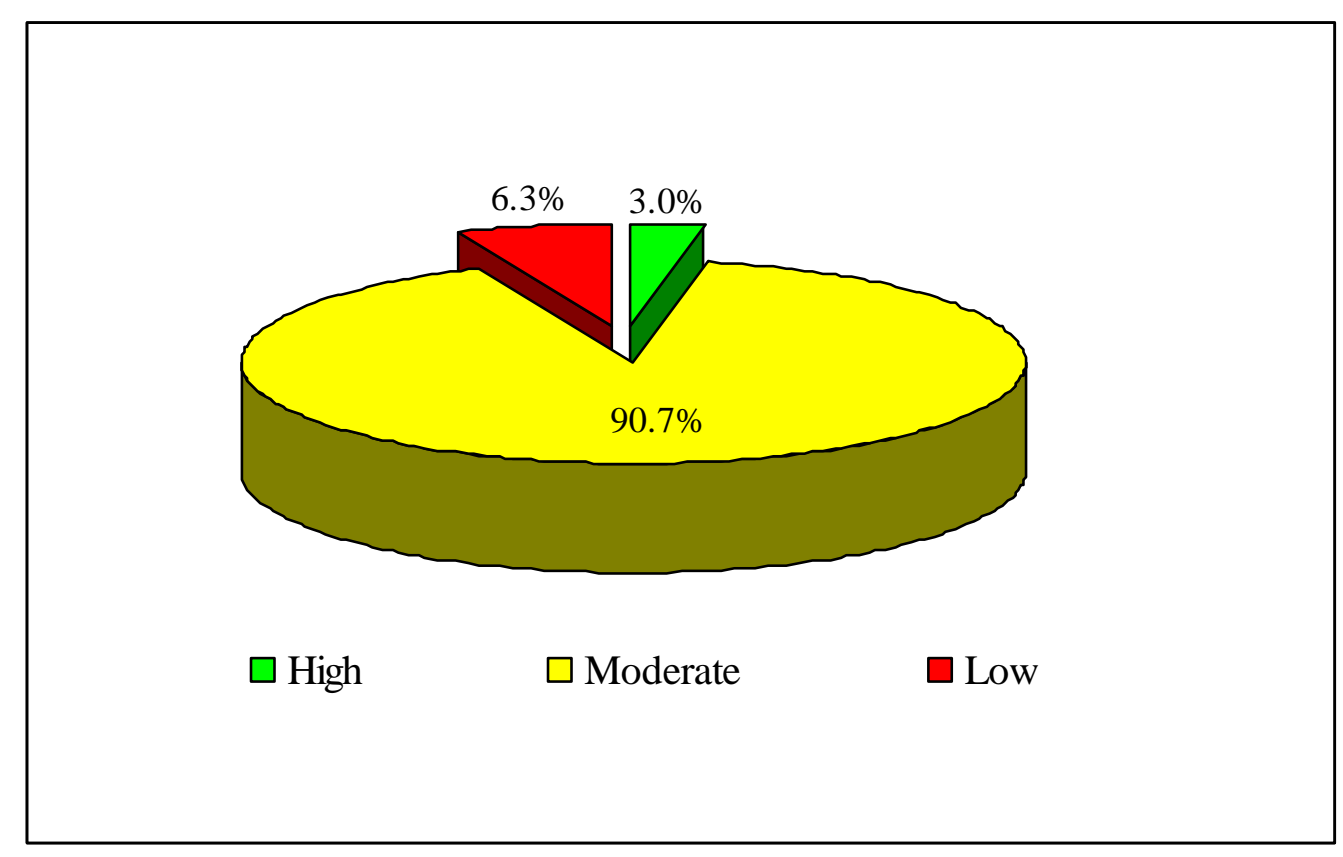

Fig.5.2 Export suitability of LUP 2000

Given the AHP model and the assignment rules of table 5.1, only 3\% area of the district was assigned by LUP 2000 in a way that is classified as "highly suitable". In these areas, 
the landslide susceptibility is low. Likewise, $90.7 \%$ area of the district, equivalent to 49,829 ha, the classification of LUP 2000 is judged as only "moderately suitable". Of this area, $62 \%$ had a "moderate" and 35\% a high landslide susceptibility classification (fig 4.8). Specifically forest use including reforestation planned by LUP 2000 results in moderate suitability even if the landslide risk rating was high. Notably, $6.3 \%$ area of the district was estimated as lowly suitable or unsuitable for the land use types assigned by LUP 2000. Here, landslide susceptibility was "high".

In comparison with $35 \%$ area of the district predicted as high susceptibility, the land use activities in LUP were quite suitable as well. Indeed, Cumpheo commune was the largest with 693 ha for low suitability, after that Chiengchau and Maihich communes were the second and third largest communes with 383 ha and 351 ha, respectively. On the contrary, Tanson commune was the smallest for low suitability with only nearly 11 ha. The larger communes were Bakhan and Thungkhe with around 11 ha and 25 ha, respectively (appendix 2). The categories of suitability of each land use type are shown in table 5.2

Table 5.2 Suitability category of land use types in Maichau District

\begin{tabular}{lrrr}
\hline \multirow{2}{*}{ Land use type } & \multicolumn{3}{c}{ Category of suitability (ha) } \\
\cline { 2 - 4 } & High & Moderate & Low \\
\hline Agriculture & 476.95 & $4,801.30$ & $2,018.73$ \\
Forest & $1,088.31$ & $44,064.03$ & \\
Residence & 75.35 & 526.79 & 480.90 \\
Infrastructure & 0.99 & 27.56 & 16.94 \\
Unused & 1.37 & 409.58 & 939.85 \\
\hline Total & $1,642.97$ & $49,829.27$ & $3,456.43$ \\
\hline
\end{tabular}

Source: Own calculation

The table 5.2 shows that forest and agricultural areas on the high level of suitability accounted for the highest position with roughly 1,088 ha and 477 ha, respectively. Conversely, areas of infrastructure and unused land were the smallest, with nearly 1.0 ha and 1.4 ha, respectively. Similarly, on the moderate level, areas of forest and agriculture were continuously the largest and area for infrastructure was the smallest. Interestingly, on the low level, area of agriculture hit the highest position, with nearly 2,019 ha, after that, 
unused land stood at the second with 940 ha. Area of residence was nearly the same with moderate level, standing at 480.9 ha. For area of infrastructure, there was around 17.0 ha where it was lowly suitable.

To sum up, it is technically feasible to generate an AHP landslide susceptibility model based in widely available scientific input data and expert judgments on a number of criteria known to influence landslide susceptibility. Such model can be used to investigate the suitability of a land use classification, for example, as provided by the Maichau District Land Use Planning for the period of 2000-2010. As data and expertise of the type used are widely available in Vietnam, the transferability of the analytic procedures chosen is very high. How accurate and useful the exact model is, still needs to be ascertained. This test can be seen as the first step in an iterative refinement of the model in face of its empirical and economic performance. The first test follows in the next sections. 


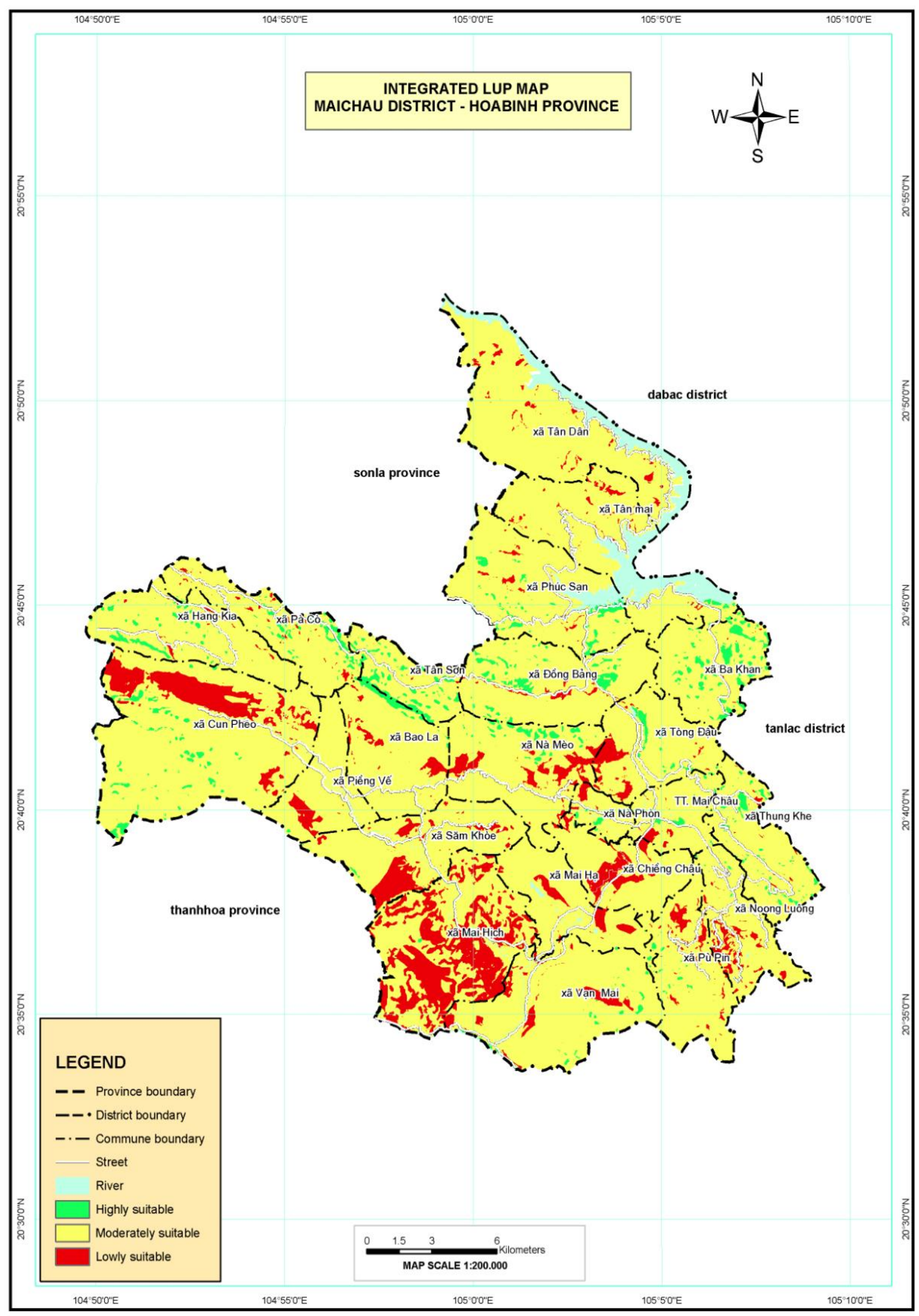

Fig.5.3 Integrated map in Maichau District, Hoabinh Province, Vietnam 
5.2 Actual landslides in Maichau District (2000 - 2010) and overlapping with landslide susceptibility.

\subsubsection{Actual landslide events in Maichau District from 2000 to 2010}

The investigation of actual landslide events were carried out at 22 communes and a town in Maichau District using a GPS and detailed maps with scale of 1:5000 and 1:2000. In particular, one official of the local Natural Resources and Environment administrations at each of the 23 communes and officials of the Department of Natural Resources and Environment at the district supported my collection of primary data. The data is shown in appendix 3, fig.5.4, and fig.5.5.

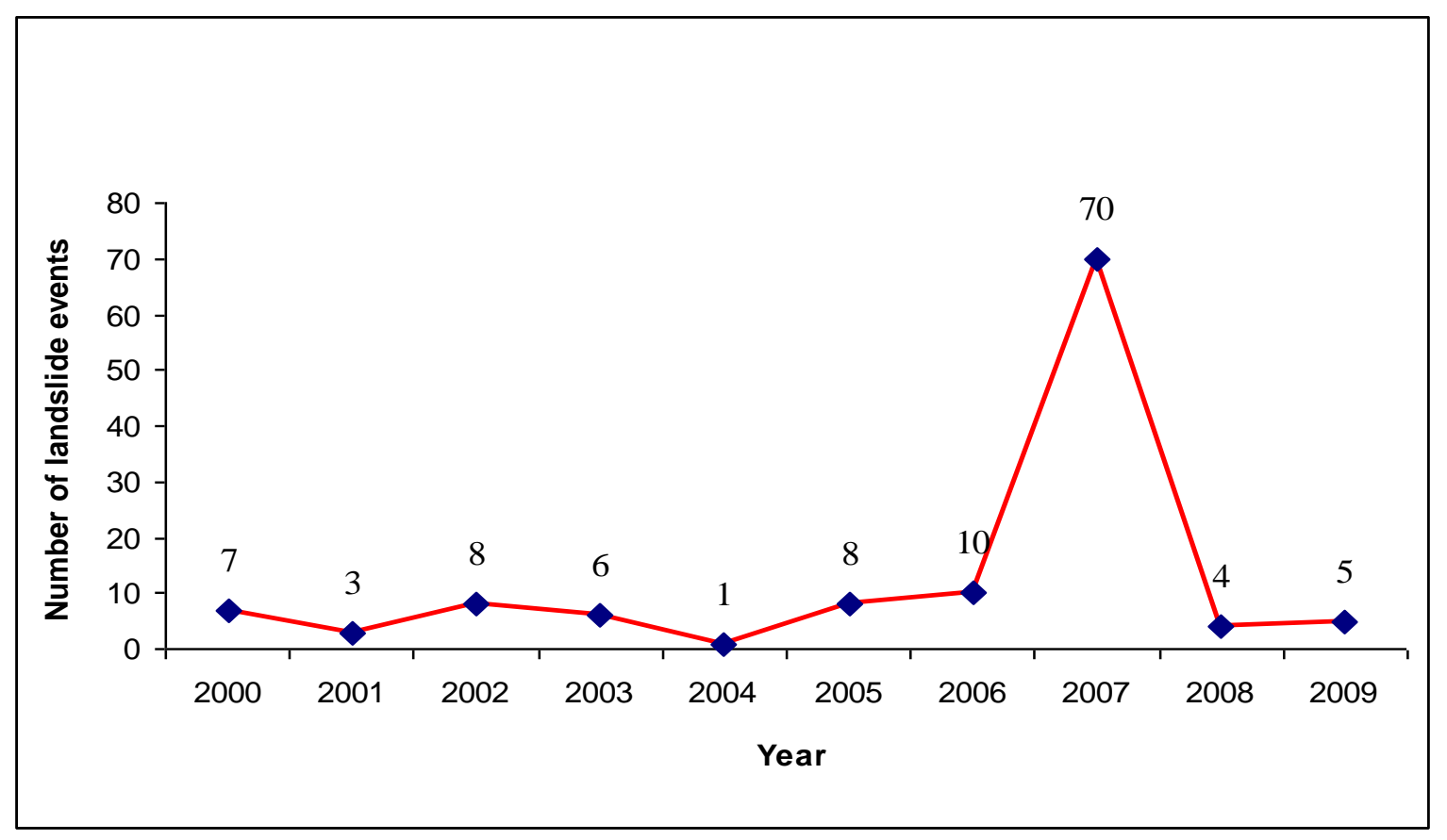

Fig.5.4 Number of landslide events from 2000 to 2010 in Maichau 


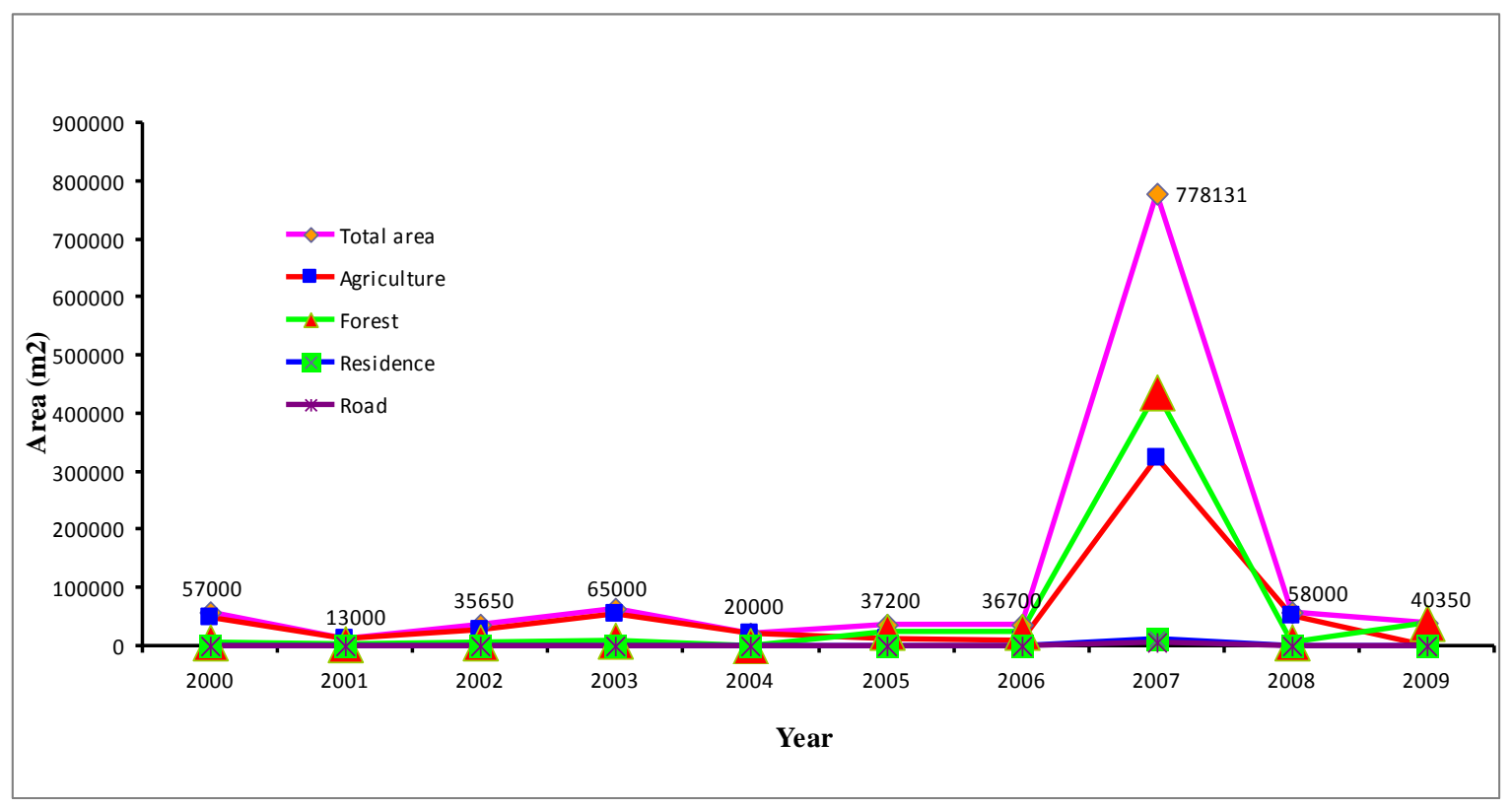

Fig.5.5 Annul area affected by landslides (2000 to 2010) in Maichau

Fig.5.4 indicates that 122 landslide events happened from 2000 to 2010 in the district, an annual frequency of 12.2. The number of landslide events was nearly flat from 2000 to 2006 and hit the peak of 70 in 2007. In comparison with the climatic data (chapter 2), the precipitation in Maichau was very high in 2007 and in particular the highest rainfall in a day was very high at $310.4 \mathrm{~mm}$ ( $4^{\text {th }}$ October, 2007) probably explaining for the largest numbers of landslide events happened in this time. The smallest numbers stood at 1 and 3 in 2004 and 2001, respectively. According to the investigation, 6 deaths caused by landslides were confirmed in the period which is a concern of local people to avoid or diminish the damages of landslides.

Total area affected by landslides was 114.10 ha, an annual average of 11.4 ha, including: agriculture (56.28 ha), forest (55.48 ha), residence (1.51 ha) and road (0.83 ha). This area fluctuated normally from 4.0 ha to 6.0 ha in a year and climbed the peak of nearly 78 ha in 2007. Interestingly, from 2000 to 2004, the area of agriculture was the largest ranging from 1.1 ha to 5.5 ha. The smaller area was forest ranging from 0.7 ha to 1.0 ha. The areas of residence and road were merely 0.04 ha and 0.05 ha in 2002, respectively. However, from 2005 to 2009 , the area of forest surged over the agriculture became the largest and hit the peak of 43 ha in 2007 (except in 2008). The second largest was agriculture that also continuously increased and hit the peak of 32 ha in 2007, as well. The areas of residence and road rose gradually and hit the peak of 1.3 ha and 0.7 ha in 2007 , respectively. 
In term of volume, different ways are obviously used to determine, such as: $\mathrm{m}^{3}, \mathrm{~m}^{2}$ (Dai et al., 2001; Dai et al., 2002; Westen et al., 2006). According to own investigation, 122 landslide events were classified into three classifications, of which 10 landslide events had area $<1000 \mathrm{~m}^{2}, 83$ landslide events had area from $1000 \mathrm{~m}^{2}-10000 \mathrm{~m}^{2}$, and lastly 29 landslide events had area $>10000 \mathrm{~m}^{2}$.

In short, the landslides happened frequently in the past period in the district posing a substantial obstacle to some important forms human land use. Actually, local land users, decision-makers, planners can consult the results to know where and when actual landslides occurred frequently in the district to propose the optimal measures to lessen severe impacts. In addition, based on the statistics, the analysis of economic damages of landslides and cost-benefit analysis of integration of landslide susceptibility into LUP will be conducted in the further researches. Moreover, the results are significant documents to verify the accuracy of the landslide susceptibility prediction when overlapping the actual landslides and landslide susceptibility will be conducted.

\subsubsection{Overlapping between actual landslides and landslide susceptibility}

The results of a landslide susceptibility analysis are potentially useful for land users and decision makers who are responsible for proposing the land use scenarios in the short and long future (Guzzetti, 2002; Guzzetti et al., 2005; Lee \& Dan, 2005). Obviously, the changes of land use have also been based on the events that happened in the previous periods (Cuong, 2005a: p37-45; Koomen \& Beurden, 2011: p37). Overlapping actual landslides from 2000 to 2010 and landslide susceptibility helps to verify the accuracy of the prediction and synthesizes background data for cost-benefits analysis. The results of the overlapping are shown in table 5.3. 
Table 5.3 Results of overlapping between actual landslides and landslide susceptibility

\begin{tabular}{|c|c|c|c|c|c|c|c|c|}
\hline \multirow{2}{*}{$\begin{array}{c}\text { Category of } \\
\text { Landslide } \\
\text { susceptibility }\end{array}$} & \multicolumn{2}{|c|}{$\begin{array}{c}\text { Number of } \\
\text { landslide events }\end{array}$} & \multicolumn{6}{|c|}{ Affected area (ha) } \\
\hline & Number & $(\%)$ & Agriculture & Forest & Residence & Road & Total & $(\%)$ \\
\hline High & 94 & 77.05 & 43.70 & 43.18 & 0.84 & 0.61 & 88.33 & 77.41 \\
\hline Moderate & 28 & 22.95 & 12.58 & 12.30 & 0.67 & 0.22 & 25.77 & 22.59 \\
\hline Low & 0 & 0.00 & 0.00 & 0.00 & 0.00 & 0.00 & 0.00 & 0.00 \\
\hline Total & 122 & 100 & 56.28 & 55.48 & 1.51 & 0.83 & 114.10 & 100 \\
\hline
\end{tabular}

Source: Own calculation

The results show that around $77 \%$ number of events and area of actual landslides actually happened on pixels classified as having a high level of landslide susceptibility. On the moderate level, nearly $23 \%$ of the affected area and number of landslides occurred. Notably, no landslide happened in the previous period of 10 years on the low level. Actually, areas of agriculture and forest equally slid from 2000-2010 on each level. These areas affected at high level of susceptibility were higher roughly 3.5 times larger that the area on the moderate level, similarly with the road's area. On the other hand, the area of residence on the high level was larger than on the moderate level with only 0.17 ha. In comparison with other land use types, the difference of affected residential land between two levels of landslide susceptibility was not large. It can be possibly explained by human activities in residential areas. 


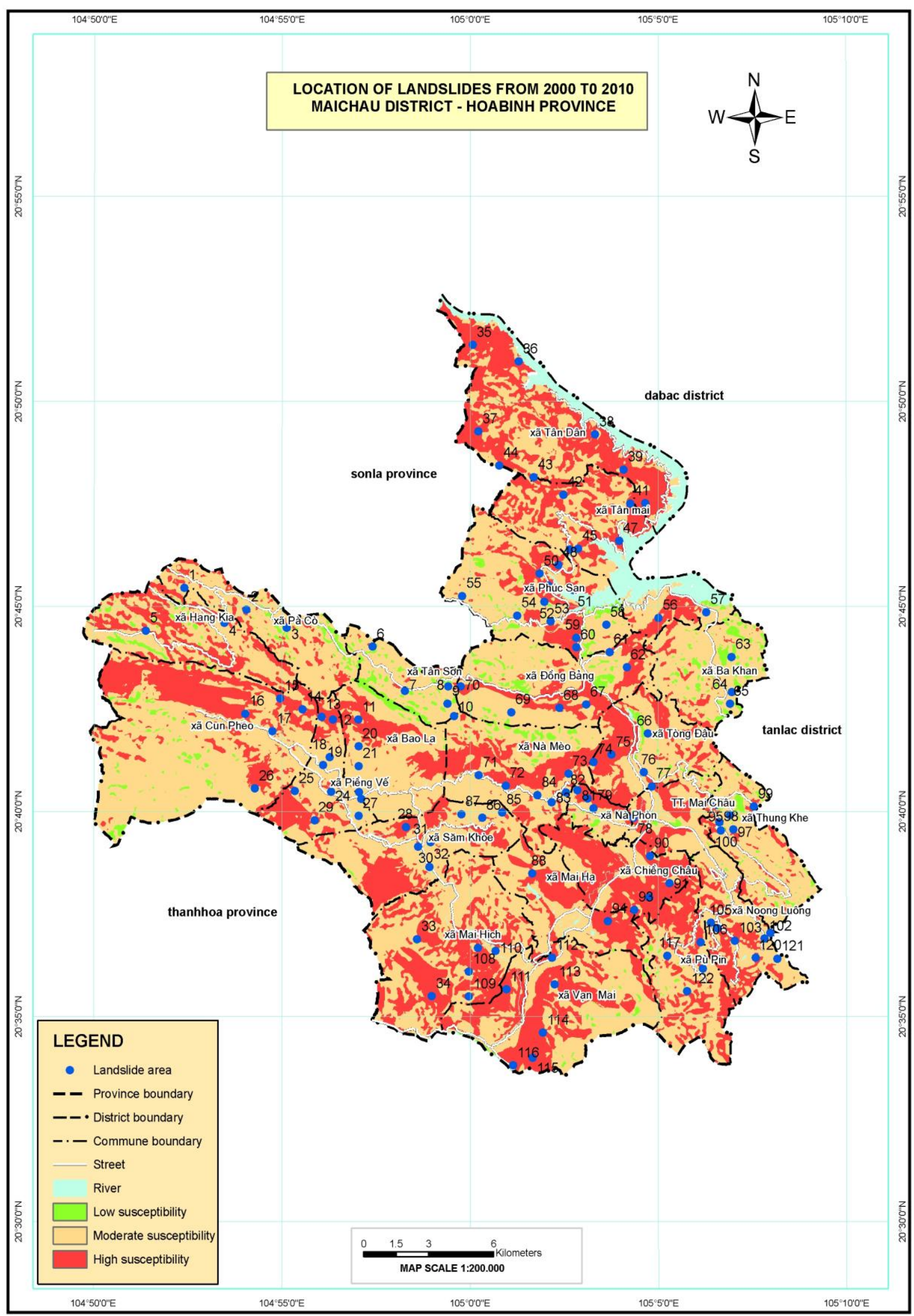

Fig.5.6 Location of landslide events from 2000 - 2010 in Maichau District 
The results show that more than $77 \%$ of area and numbers of landslide events was predicted correctly as happening in areas classified into the high category of landslide susceptibility. Therefore, the accuracy of prediction appears as acceptable. The results can be consulted by land users, planners, decision makers to support first ideas on the change of land use types. Obviously, lessening or minimizing the number and area of landslide events can be integrated in different action plans via the change of land use types. From an economic point of view, the fact alone that more than $3 / 4$ of the landslides were predicted correctly raises one more question: At what cost, would a LUP come that outlaws high value land use on all areas categorized as highly susceptible in Maichau District? This question is picked up in the following section.

\subsection{Benefit of integration of landslide susceptibility into LUP}

\subsubsection{Simple cost-benefit analysis model of the integration}

Cost-Benefit Analysis (CBA) is an important tool for supporting decisions on the rational use of public funds or on public planning alternatives that have economics implications - as is often the case in the environmental sector. CBA aims at the assessment of the social benefits generated by some environmental project in order to compare these benefits to the costs of the project or to the social benefits generated by other projects (Ahlheim et al., 2010). According to Boardman et al. (2006: p2), cost-benefit analysis is understood as a policy assessment method that quantifies in monetary terms the value of all consequences of a policy to all members of society. Moreover, CBA can be thought of as providing a framework for measuring efficiency. And it provides a method making direct comparison among alternative policies. Almansa and Martínez-Paz (2011) argued that CBA is changing in two ways. The first is the development of new tools for the economic evaluation of environmental externalities traditionally omitted from the analysis. The second is an in-depth revision of the theoretical foundations underlying the traditional approaches to discounting, since the repercussions of current decisions will extend into the future.

Many applications of CBA regard of macro-environmental standards and constraints (Doeleman, 1985). The valuations of CBA have supported choosing the best projects with 
higher/ or positive social welfare. It also contributes significantly to decision makers in selecting better ways for sustainable development, so that it is regarded as a useful tool for decision makers (Dinkel, 1985; Hofmanna \& Wangenheim, 2003; Simpson \& Walker, 1987). Furthermore, Munda (1996) argued that CBA is necessary to place monetary values on non-market goods, such as: clean air, clean water, biodiversity and wilderness areas. A cost-benefit assessment should consider the total value of benefits received compared to the total costs incurred in the project (Hansjürgens, 2004; Thomas \& Blakemore, 2007). All economically relevant impacts of a policy must be valued in monetary terms. Unless they are, a cost-benefit analysis can give, misleading results (Elvik, 2001).

In own previous research, landslide susceptibility and the integration of landslide susceptibility into LUP in Maichau District were carried out. The results show that where there was high, moderate, and low susceptibility for landslide, and where was high, moderate, and low suitability for the land use types proposed readily in LUP in comparison with landslide susceptibility. Moreover, the results also pointed out some limitations of LUP in the previous period without the landslide component. However, economically, it raised a concern of whether to integrate landslide susceptibility into LUP. In order to assess benefit of the integration of landslide hazards from an environmental economics point of view, benefit and cost of a more environmentally integrated LUP must be concerned. Therefore, cost-benefit analysis needs to be calculated by simple model:

Net benefit of landslide risk integration = Benefits of avoided damage of correctly predicted landslides - Costs of integration of landslide susceptibility into LUP

The aim of this simple model is to compare the benefits gained by the integration and the costs of the integration. Therefore, the integration's efficiency will be assessed by the environmental economics point of view.

\subsubsection{Benefits of avoided damage of correctly predicted landslides}

Calculating the benefit of the integration of landslide risks into LUP needs to assess the damage that would have been avoided if a better integrated LUP had been in place in 2000 and implemented accordingly. 
When determining the damage of disaster, Richard (1995) stated that some of the damage costs will grow with the economy and the population, others will decline relatively, such as: agricultural losses in developing countries, and others will increase, particularly the intangibles. However, the true costs of disasters are not easy to identify and quantify because they include total direct and indirect costs and benefits. The damage of disasters can include different aspects, such as: crop losses, repairs to public infrastructure, property, and buildings. Thus, most of the losses involve physical damage to property, and disaster costs are growing largely over the world because of increasing societal vulnerability to disasters (Downton \& Pielke, 2005). Based on the Thieken et al. (2008), crop loss is calculated as a percental deduction of the perennial averaged yields. Therefore, crop losses include loss of total investment and ability to have income.

Total Landslide Damage Cost (TLDC): A number of landslide events happened in the case study district in the past 10 years from 2000 to 2010. Some of these landslides happened in areas used by agriculture, infrastructures or as residential areas ("villages"). Therefore, total damage of a landslide is defined as Landslide Damage Cost (LDC). Accordingly, the landslides have caused a certain total cost (Total Landslide Damage Cost of the past 10 years: TLDC) which was determined by an equation:

$$
T L D C=\sum_{i=1}^{n} L D C_{i}
$$

where $\quad \mathrm{i}$ : The individual landslide i (1-n)

LDC: individual Landslide Damage Cost

Avoided Landslide Damage Cost $(A L D C)$ : Which fraction of the total landslide damage cost (TLDC) could have been avoided if the integrated LUP had been used and observed? Obviously, that fraction of the damage that happened on areas labeled as unsuitable in the integrated map (integrated LUP). So for each of the actual landslides $i=1$ to $n$ it needs to be determined where it happened and if its location was labeled as unsuitable for different land use types. Those landslides (correctly occurred) on unsuitable area for land use types could be avoided if landslide susceptibility and LUP were integrated. Thus, the Avoided Landslide Damage Cost of the past 10 years $\left(\mathrm{ALDC}_{10}\right)$ was calculated by equations: 


$$
A L D C=\sum_{i=1}^{n} L D C_{i} * X_{i}
$$

where $\quad$ i: The individual landslide i (1-n)

$$
\begin{aligned}
& X_{i}=0 \text { if not "unsuitable" rating assigned } \\
& X_{i}=1 \text { if "unsuitable" rating assigned }
\end{aligned}
$$

To determine the Landside Damage Cost caused by actual landslides on agriculture and forest, the equation was used to analyze the data which was based on the actual investment and income of land users, as follows:

\section{Landslide Damage Cost $=$ Investment Lost + Potential Net Income Lost}

Investment Lost were all investments (total costs) in land use lost by a landslide which was calculated for each household and averaged for all households.

Potential Net Income Lost is understood as a loss of ability to have net income. If landslides did not happen, land users would have this net income that was calculated for total lifetime of crop. The potential net income was based on the actual lifetime of crop before the happening of landslide. It can be estimated as potentially yield socially desirable outcomes in agricultural activities (Fraser, 2009).

The investment period was actually long, in particularly for forest, 7 years for Acacia, 14 years for Bamboo. Therefore, present cash flow with an interest rate for cost, revenue and net income was used to determine the landslide damage cost on forest.

The present cash flow of cost, revenue and net income were conducted by the method Future Value Analysis and Present Value Analysis (Boardman et al., 2006: p135-136); The equation was used to calculate:

$$
F_{v}=P_{v}(1+i)^{t}
$$


where: $F_{v}$ : Future value

i: Interest rate
$\mathrm{P}_{\mathrm{v}}$ : Present value

t: Time (year)

Future value: The method compares what the project will receive in the future if money invests in the project with what it will receive in the future if it invests in the best alternative. The value plus interest is called the future value, $F_{V}$ (Boardman et al., 2006: p132).

Present value: A switch from future value to present value. Present Value Analysis compares the current equivalent value of investing in the project with the current equivalent value of investing in the best alternative project, given prevailing interest rates. The current equivalent value of amount that will be received in the future is called its present value, $\mathrm{P}_{\mathrm{V}}$ (Boardman et al., 2006: p133).

Net Present Value (NPV) is calculated by equation (Boardman et al., 2006: p137):

$$
N P V=\sum_{t=0}^{n} \frac{B_{t}}{(1+i)^{t}}-\sum_{t=0}^{n} \frac{C_{t}}{(1+i)^{t}}
$$

where: B: Benefit; C: Cost; t: Time (year); i: Interest rate

Equivalent Annual Annuity (EAA): The equivalent annual annuity (EAA) method circumvents the difficulty of discounting cash flows over an unrealistically long evaluation period (Volkman, 1997) and it is calculated by equation (Boardman et al., 2006: p145156):

$$
E A A=\frac{i(N P V)}{1-(1+i)^{-n}}
$$

where: NPV: Net Present Value

i: Interest rate

n: year 


\subsubsection{Damage of actual landslides on agriculture $(2000-2010)$}

According to the "Second National Strategy and Action Plan for Disaster Mitigation and Management in Vietnam from 2001 to 2020", about eight thousand people were killed, 2.3 million tons of foods were destroyed, and 6 million houses collapsed and washed away by natural disasters in the decade of 1991 to 2000. The total estimated economic loss was about USD 2.8 billion, i.e. 1.8-2.3\% of the national GDP or nearly USD 300 million yearly (Van et al., 2006). Ahlheim et al. (2008) assumed that affected households in northwest part of Vietnam lose about $6 \%$ of their total annual incomes as a consequence of landslide events.

According to statistical data in Maichau District, nearly $90 \%$ of the population lived in rural areas and 36.02\% GDP was from agricultural sector in 2010 (GSO Hoa Binh, 2010; GSO Mai Chau, 2010). The local people in upland area, in general, and in Maichau, in particular, had some limitations of education and handcrafts. Thus, their food security and living standards had to depend largely on agricultural-forest activities (Cuong, 2005a: p327). Damages of natural disasters on agricultural activities have been more significant because of regarding directly to local people's living.

To specify the damage of landslides in Maichau, 65 households affected by the actual 122 landslide events from 2000 to 2010 were investigated on investment, benefit and income. In which 17, 41 and 7 households planted rice, maize and cassava, respectively. Landslide damage cost was calculated by equation (3). The results are shown in table 5.4. 
Table 5.4 Damage of actual landslides $\mathrm{ha}^{-1}$ on agriculture $(2000-2010)$

\begin{tabular}{lccc}
\hline & $\begin{array}{c}\text { Rice } \\
(\mathrm{n}=17)\end{array}$ & $\begin{array}{c}\text { Maize } \\
(\mathrm{n}=41)\end{array}$ & $\begin{array}{c}\text { Cassava } \\
(\mathrm{n}=7)\end{array}$ \\
\hline Seed (VND million) & 2.70 & 2.37 & 0.00 \\
Plough land (VND million) & 2.97 & 2.46 & 2.38 \\
Fertilizer (VND million) & 4.43 & 2.96 & 2.46 \\
Pesticide (VND million) & 2.27 & 0.81 & 0 \\
Paid labour (VND million) & 5.31 & 5.95 & 5.32 \\
Other costs (VND million) & 1.11 & 0.83 & 0.83 \\
\hline Total costs(VND million) & 18.79 & 15.38 & 11.0 \\
\hline Productivity (ton/ha) & 4.60 & 2.98 & 8.36 \\
Price (million/ton) & 5.5 & 6.5 & 1.5 \\
Revenue (VND million) & 25.30 & 19.34 & 12.54 \\
\hline Net income (VND million) & 6.51 & 3.97 & 1.54 \\
Potential net income (VND million) & 6.51 & 3.97 & 1.54 \\
Landslide Damage Cost (VND million) & 25.30 & 19.34 & 12.54 \\
\hline
\end{tabular}

Source: Own investigation and calculation (Currency: Euro = VND 29,000 in 10/2011)

For agricultural crops, cost, revenue and net income were calculated per ha. From household data, the average of all households was calculated. The actual "lifetime" of agricultural crops was 3/4 total lifetime of these crops. The actual "lifetime" can be defined as the time from first land preparation for seeding to the point in time, when the landslide happened.

In Vietnam, average agricultural area per capita was very small at $1,160 \mathrm{~m}^{2}$ and annual crop was at $740 \mathrm{~m}^{2}$ (Anonymous, 2010d; GSO, 2010). Table 5.4 indicates that the total costs of rice crop $\mathrm{ha}^{-1}$ were m18.8 VND higher than those of maize and cassava with m15.4 VND and m11 VND, respectively. The revenue of rice crop, similarly, was the highest with m25.3 VND ha ${ }^{-1}$, after that m19.3 VND and m12.5 VND for maize and cassava. Landslide damage cost on rice crop was the largest with $\mathrm{m} 25.3 \mathrm{VND} \mathrm{ha}^{-1}$. The second and third were maize and cassava with m19.3 VND ha ${ }^{-1}$ and m12.5 VND ha-1, respectively. 


\subsubsection{Damage of actual landslides on forest (2000-2010)}

The results in fig 5.5 show that the slid forest areas increased gradually in the period of 10 years from 2000 to 2010. Thus, it is important to quantify the forest areas in order to calculate the total damage of landslides. Forest has, generally, contributed very large amounts of money to land user income and sustainable development in mountainous regions (Tan, 2006), particularly in hunger elimination and poverty alleviation in Vietnam (William, 2006).

To determine the Landslide Damage Cost on forest from 2000 - 2010 in Maichau, 64 households planting forest damaged by actual landslides were investigated in detail. In which 4 and 60 households planted Acacia and Bamboo, respectively. These households were affected by 64 landslides in the research area. For the affected Acacia and Bamboo, two different forest rotations need to be applied in the calculation of potential net income: 7 years for Acacia and 14 year for Bamboo. The landslides can happen in any of the 7 or 14 years of the rotation. Thus, present cash flow was applied to carry out for each year with the interest rate 9\% per year (Vietnam Bank for Social Policies and Agri-Bank).

The costs and revenue were investigated in each year of forest cultivation. The costs included seedling for the first year, fertilizer, labour and others for all forest lifetime. The forest revenue gained annually (nominal data shown in appendix 4, 5). However, Acacia was harvested merely one time in the last year of the rotation and to mainly supply pulp producing for paper industry. For bamboo, harvesting was carried out during the dry season, from November to following January from the $5^{\text {th }}$ year of the rotation when the culm nutrient and starch content are the lowest with the aim to prevent culms being attacked by borers (Ha, 2010: p95). Bamboo shoot is a by-product of bamboo, and it contributes largely to total revenue of bamboo. Normally, the by-product is harvested by farmers in annual spring and summer. According to own investigation and Ha (2010: p98), from the $5^{\text {th }}$ and $6^{\text {th }}$ year of lifetime, the harvesting was carried by selective cutting method based on model 1:2:1 (Dien, 2006) defined as: Young : Mature : Old stem.

Notably, landslides probably happen in different periods of the forest rotation. The happening can range from $1^{\text {st }}$ year to $7^{\text {th }}$ year for acacia and $1^{\text {st }}$ year to $14^{\text {th }}$ year for bamboo. Therefore, the happening was simulated by possibility from $1^{\text {st }}$ to $7^{\text {th }}$ year for 
acacia and $1^{\text {st }}$ to $14^{\text {th }}$ year for bamboo. Present cash flow of cost, revenue and income of forest was calculated by equation (4). Landslide Damage Cost on forest was calculated by an equation (3).

Obviously, natural disasters trigger many risks for land users. Of which potential net income is understood as an indispensable part of total damages on forest. It would be able to have an income if landslides did not happen. In fact, it was calculated in each year of the rotation. In actual investigated data, present cash flow was calculated and shown in the table 5.5, table 5.6 and appendix 4, 5 .

Table 5.5 Damage of actual landslides on Acacia ha $^{-1}$ in Maichau District

\begin{tabular}{|c|c|c|c|c|c|c|c|c|}
\hline \multirow[b]{2}{*}{$\begin{array}{c}\text { Year } \\
\text { landslide } \\
\text { happened }\end{array}$} & \multicolumn{8}{|c|}{ Accumulated } \\
\hline & $\begin{array}{l}\text { Total } \\
\text { costs }\end{array}$ & $\begin{array}{c}\text { Total } \\
\text { revenue }\end{array}$ & $\begin{array}{c}\text { Net } \\
\text { income }\end{array}$ & $\begin{array}{l}\text { Present } \\
\text { cash flow } \\
\text { (Cost) }\end{array}$ & $\begin{array}{c}\text { Present } \\
\text { cash flow } \\
\text { (Revenue) }\end{array}$ & $\begin{array}{c}\text { Present } \\
\text { cash flow } \\
\text { (Net } \\
\text { income) }\end{array}$ & $\begin{array}{l}\text { Potential Net } \\
\text { Income }\end{array}$ & $\begin{array}{c}\text { Landslide } \\
\text { Damage } \\
\text { Cost }\end{array}$ \\
\hline Year $^{+1}$ & 9.56 & 0.00 & -9.56 & 9.56 & 0.00 & -9.56 & 4.32 & 13.88 \\
\hline Year $^{+2}$ & 12.20 & 0.00 & -12.20 & 13.06 & 0.00 & -13.06 & 9.42 & 22.47 \\
\hline Year $^{+3}$ & 13.57 & 0.00 & -13.57 & 15.61 & 0.00 & -15.61 & 15.40 & 31.00 \\
\hline Year $^{+4}$ & 14.95 & 0.00 & -14.95 & 18.39 & 0.00 & -18.39 & 22.37 & 40.76 \\
\hline Year $^{+5}$ & 16.32 & 0.00 & -16.32 & 21.41 & 0.00 & -21.41 & 30.49 & 51.90 \\
\hline Year $^{+6}$ & 17.70 & 0.00 & -17.70 & 24.72 & 0.00 & -24.72 & 39.88 & 64.59 \\
\hline Year $^{7}$ & 19.17 & 0.00 & -19.17 & 28.42 & 0.00 & -28.42 & 50.71 & 79.13 \\
\hline
\end{tabular}

Source: Own investigation and calculation (Unit: VND million) 
Table 5.6 Damage of actual landslides on Bamboo ha ${ }^{-1}$ in Maichau District

\begin{tabular}{|c|c|c|c|c|c|c|c|c|}
\hline \multirow{2}{*}{$\begin{array}{c}\text { Year } \\
\text { landslide } \\
\text { happened }\end{array}$} & \multicolumn{8}{|c|}{ Accumulated } \\
\hline & $\begin{array}{l}\text { Total } \\
\text { costs }\end{array}$ & $\begin{array}{c}\text { Total } \\
\text { revenue }\end{array}$ & $\begin{array}{c}\text { Net } \\
\text { income }\end{array}$ & $\begin{array}{c}\text { Present } \\
\text { cash flow } \\
(\text { Cost })\end{array}$ & $\begin{array}{c}\text { Present } \\
\text { cash flow } \\
\text { (Revenue) }\end{array}$ & $\begin{array}{c}\text { Present } \\
\text { cash flow } \\
(\mathrm{Net} \\
\text { income })\end{array}$ & $\begin{array}{l}\text { Potential Net } \\
\text { Income }\end{array}$ & $\begin{array}{c}\text { Landslide } \\
\text { Damage } \\
\text { Cost }\end{array}$ \\
\hline Year $^{+1}$ & 6.48 & 0.00 & -6.48 & 6.48 & 0.00 & -6.48 & 3.72 & 10.19 \\
\hline Year $^{+2}$ & 8.62 & 0.00 & -8.62 & 9.21 & 0.00 & -9.21 & 8.10 & 17.31 \\
\hline Year $^{+3}$ & 10.73 & 0.00 & -10.73 & 12.14 & 0.00 & -12.14 & 13.24 & 25.38 \\
\hline Year $^{+4}$ & 12.51 & 0.00 & -12.51 & 15.01 & 0.00 & -15.01 & 19.25 & 34.26 \\
\hline Year $^{+5}$ & 14.29 & 0.00 & -14.29 & 18.15 & 0.00 & -18.15 & 26.23 & 39.13 \\
\hline Year $^{+6}$ & 16.07 & 5.57 & -10.50 & 22.37 & 6.07 & -16.29 & 33.96 & 50.25 \\
\hline Year $^{+7}$ & 17.86 & 13.83 & -4.03 & 25.28 & 15.62 & -9.67 & 43.62 & 53.29 \\
\hline Year $^{+8}$ & 19.64 & 27.56 & 7.92 & 29.34 & 31.99 & 2.65 & 54.34 & 51.69 \\
\hline Year $^{+9}$ & 21.42 & 45.51 & 24.09 & 33.77 & 54.43 & 20.67 & 66.63 & 45.97 \\
\hline Year $^{+10}$ & 23.20 & 63.85 & 40.65 & 38.59 & 79.33 & 40.74 & 80.70 & 39.96 \\
\hline Year $^{+11}$ & 25.04 & 82.20 & 57.16 & 43.89 & 106.47 & 62.57 & 96.76 & 34.19 \\
\hline Year $^{+12}$ & 26.87 & 102.15 & 75.27 & 49.68 & 137.79 & 88.11 & 115.06 & 26.95 \\
\hline Year $^{+13}$ & 28.78 & 121.29 & 92.52 & 56.06 & 171.06 & 115.01 & 135.86 & 20.85 \\
\hline Year $^{+14}$ & 30.74 & 140.44 & 109.70 & 63.07 & 207.33 & 144.26 & 159.48 & 15.22 \\
\hline
\end{tabular}

Source: Own investigation and calculation (Unit: VND million)

The results, synthesized in table 5.5, 5.6, and fig 5.7, indicate that the landslide damage cost changed quite differently between acacia and bamboo. Indeed, for acacia, the damage rose steadily from the year ${ }^{+1}$ to the last year of the rotation by roughly m65 VND from around m14 VND to m79 VND, respectively. On the other hand, the damage on bamboo was glanced as a concave down parabola with the highest peak of m53.3 VND at the year ${ }^{+7}$ of the lifetime. The downward went gradually into the year ${ }^{+1}$ and $y^{2} \mathrm{r}^{+14}$ with around m10.0 VND and m15.0 VND, respectively. The difference between acacia and bamboo can be explained by investment and revenue. Actually, the revenue of bamboo had regularity after the first four years of the rotation and had the largest at the year ${ }^{+7}$. Then, its revenue and investment decreased gradually to the last year (year ${ }^{+14}$ ) of the rotation. On the contrary, the revenue of acacia had only once at the last year $\left(\right.$ year $^{+7}$ ) of the rotation.

The results assume that the year ${ }^{+7}$ of acacia rotation and the year ${ }^{+6}, y^{2}{ }^{+7}, y^{2} r^{+8}$ of 
bamboo rotation were a very important period of forest lifetime. If landslides happen in this time, total losses will be the largest. The hypotheses suggest that if proper types of land use are proposed to prevent landslides in this time, such damages could be lightened to as low as possible. These results also have important implications for land users and planners in land use and land use policies in the present and future development.

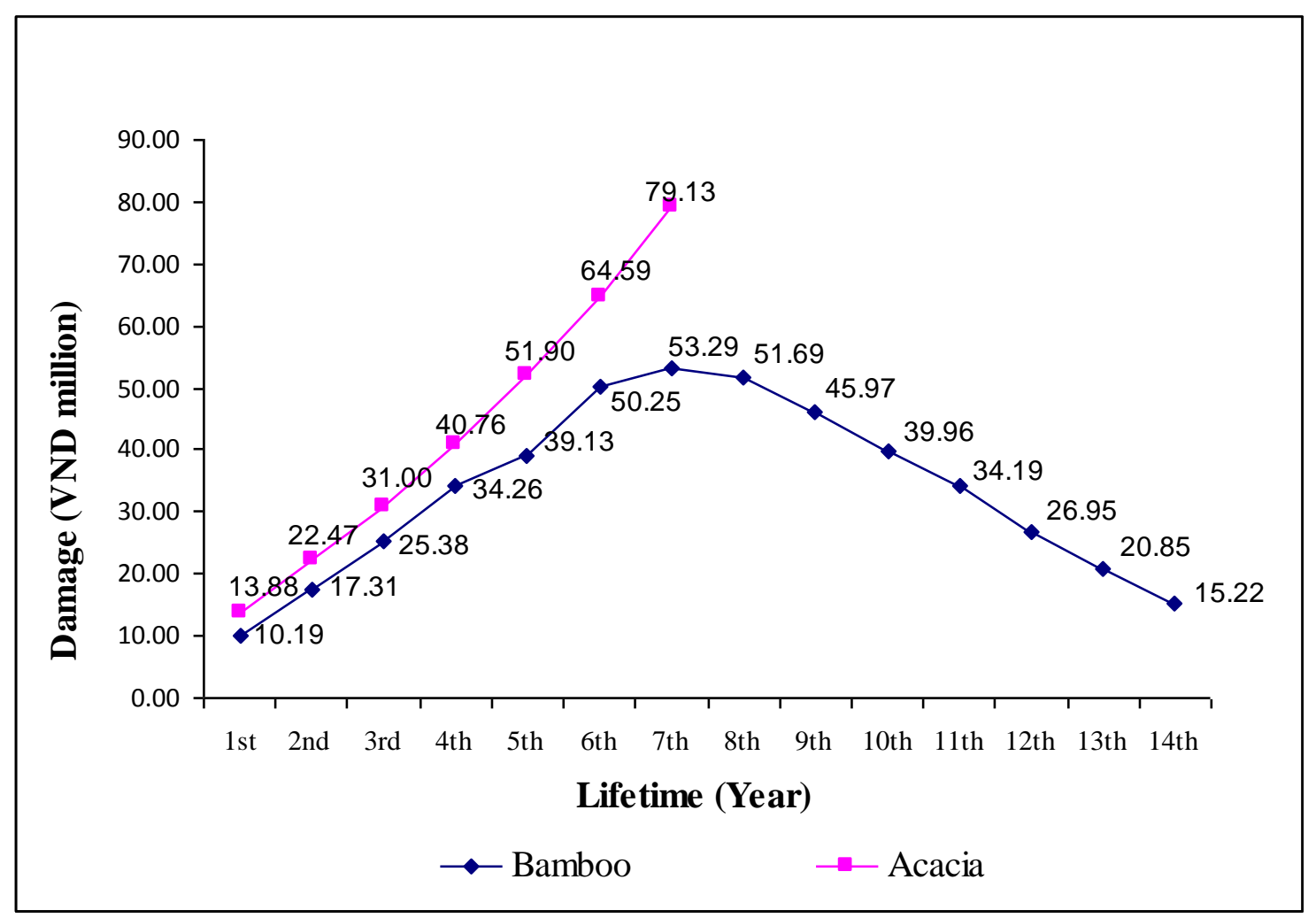

Fig. 5.7 Landslide damage cost $\mathrm{ha}^{-1}$ on forest in Maichau District

\subsubsection{Damage of actual landslides on residential area and death (2000-2010)}

The article 17, 18 and 58 of Vietnam's constitution in 1992 stipulated that the people have ownership of housing in the residential area and government allocates land stably and permanently for users (Anonymous, 1992). The Vietnam Land Law also regulated that households and individuals' residential land is allocated by government (article 34). Land where the users are allowed to have one of the rights includes: to exchange, transfer, lease, sublease, inherit, donate, mortgage land use rights, provide guarantee or make capital contribution with land use rights (article 61) (Anonymous, 2003). Thus, management and use of the residential land in Vietnam are comprehensively stipulated by legal regulations. In 
addition, population growth is normally very high (around >1\%), indeed it is $1.05 \%$ in 2010 (GSO, 2010). According to demographic investigation, the average growth from 1999 to 2009 was $1.2 \%$ in comparison with $1.7 \%$ in the previous period (Anonymous, 2010c). Therefore, the growth has caused a huge pressure to extend the residential area.

In the research area, the calculation of landslide damage cost on residential area included damage on residential land and damage on houses. Residential land has the highest value in comparison with agricultural and forest land. It is considered as the most valuable asset for farmers. Therefore, the value of land should be included in the landslide damage cost. The price of residential land was stipulated by the president of Maichau District in Decision No 34/2011/QD-UBND. The price ranged from 30,000 VND to 600,000 VND for rural area and from 45,000 VND to 2,200,000 VND for urban area. The price was divided into four groups, in which landslides that normally happened in the $4^{\text {th }}$ group were with the lower price. The price was published availably. Thus, it was easy to determine the price of the affected residential land in the district.

Totally, 19 landslides that affected residential area were investigated in 11 communes of the district. In fact, 63 households was impacted by landslides from 2000-2010. In which, 54 houses of households were destroyed by landslides. The questions of an interview with households included: How much residential area was affected due to landslides? Was the house destroyed by landslides? How much money was lost by landslides? The results were shown in table 5.7. 
Table 5.7 Damage of actual landslides on residential area (2000-2010)

\begin{tabular}{|c|c|c|c|c|c|c|c|}
\hline Commune & $\begin{array}{c}\text { ID of } \\
\text { Landslide }\end{array}$ & $\begin{array}{c}\text { No of } \\
\text { destroyed } \\
\text { household }\end{array}$ & $\begin{array}{c}\text { Damage } \\
\text { on } \\
\text { house } \\
\text { (VND } \\
\text { million) }\end{array}$ & $\begin{array}{c}\text { Affected } \\
\text { area } \\
\left(\mathrm{m}^{2}\right)\end{array}$ & $\begin{array}{c}\text { Price of } \\
\text { residential } \\
\text { land } \\
(1000 \\
\left.\mathrm{VND} / \mathrm{m}^{2}\right)\end{array}$ & $\begin{array}{l}\text { Damage } \\
\text { on } \\
\text { residential } \\
\text { land } \\
\text { (VND } \\
\text { million) }\end{array}$ & $\begin{array}{c}\text { Landslide } \\
\text { Damage } \\
\text { Cost } \\
\text { (VND } \\
\text { million) }\end{array}$ \\
\hline 1 & 2 & 4 & 5 & 6 & 7 & $8=6 \times 7$ & $9=5+8$ \\
\hline $\mathrm{PaCo}$ & 2 & 0 & & 400 & 50 & 20.00 & 20.00 \\
\hline $\mathrm{Pa} \mathrm{Co}$ & 3 & 0 & & 308 & 35 & 10.78 & 10.78 \\
\hline Hang Kia & 4 & 1 & 100.00 & 300 & 30 & 9.00 & 109.00 \\
\hline Tan Son & 7 & 0 & & 300 & 55 & 16.50 & 16.50 \\
\hline Bao La & 20 & 1 & 100.00 & 2,100 & 50 & 105.00 & 205.00 \\
\hline Bao La & 23 & 1 & 80.00 & 400 & 45 & 18.00 & 98.00 \\
\hline Tan Mai & 56 & 13 & 245.00 & 1,000 & 35 & 35.00 & 280.00 \\
\hline Phuc San & 58 & 11 & 269.00 & 1,400 & 60 & 84.00 & 353.00 \\
\hline Dong Bang & 61 & 3 & 300.00 & 700 & 55 & 38.50 & 338.50 \\
\hline Ba Khan & 64 & 0 & & 400 & 30 & 12.00 & 12.00 \\
\hline Tong Dau & 66 & 1 & 30.00 & 1,200 & 60 & 72.00 & 102.00 \\
\hline Dong Bang & 67 & 1 & 130.00 & 400 & 60 & 24.00 & 154.00 \\
\hline Dong Bang & 68 & 3 & 370.00 & 320 & 60 & 19.20 & 389.20 \\
\hline Dong Bang & 69 & 2 & 100.00 & 1,500 & 60 & 90.00 & 190.00 \\
\hline Tong Dau & 76 & 5 & 125.00 & 1,200 & 110 & 132.00 & 257.00 \\
\hline Noong luong & 101 & 0 & & 400 & 30 & 12.00 & 12.00 \\
\hline Noong luong & 104 & 0 & & 800 & 30 & 24.00 & 24.00 \\
\hline Van Mai & 116 & 12 & 580.00 & 1,200 & 70 & 84.00 & 664.00 \\
\hline $\mathrm{Pu}$ Bin & 119 & 0 & & 800 & 35 & 28.00 & 28.00 \\
\hline Total & 19 & 54 & $2,429.00$ & 15,128 & & 833.98 & $3,262.98$ \\
\hline
\end{tabular}

Source: Own investigation and calculation

The results indicate that from 2000-2010, residential area was impacted by 19 landslides, of which the damage of landslides on residential land was nearly m834 VND. And the damage on local people's houses was estimated as very high with m2,429 VND belonging to 54 households severely devastated by 12 landslides in 7 communes in the research district. Total landslide damage cost on residential area including damage on residential land and damage on houses was roughly m3,263 VND that contributed largely to total landslide damage cost from 2000 to 2010 in Maichau District.

According to the investigation, 6 deaths were caused by landslides from 2000 to 2010 in the district. All killed individuals were from 30 to 35 years old. They could have worked in 
the next 30 years, if landslides had not happened. Based on the economic point of view, this "damage" can be approximated in monetary terms using per capita GDP figures. The data in table 5.8 shows that total damage of landslides on deaths was m541.14 VND.

Table 5.8 Damage of actual landslides on death (2000 - 2010)

\begin{tabular}{ccccc}
\hline $\begin{array}{c}\text { Number of } \\
\text { death }\end{array}$ & $\begin{array}{c}\text { GDP per capita } \\
\text { (Million VND) }\end{array}$ & $\begin{array}{c}\text { Working } \\
\text { duration (year) }\end{array}$ & $\begin{array}{c}\text { Interest rate (\%) } \\
\text { loss) (Million } \\
\text { VND) }\end{array}$ \\
\hline 6 & 8.0 & 30 & 9 & 541.14 \\
\hline
\end{tabular}

Source: Own investigation and calculation

\subsubsection{Damage of actual landslides on road system (2000-2010)}

According to the traffic law in article 39, six categories of the road system are defined in Vietnam, as follows: highway, provincial road, district road, communal road, urban road and specialized road. The investigation was carried out at the Department of Transportation and at communes. First of all, the statistical data on the damage of actual landslides on the road system was collected directly. Specifically, the length of the road, the volume of removed land and the cost of reconstruction of the road was investigated in the Department of Transportation. Finally, this data was confirmed in the communes when the field trip was conducted. 
Table 5.9 Damage of actual landslides on road system $(2000-2010)$

\begin{tabular}{lcccccc}
\hline Commune & $\begin{array}{c}\text { ID of } \\
\text { landslide }\end{array}$ & $\begin{array}{c}\text { Length of } \\
\text { Road (m) }\end{array}$ & $\begin{array}{c}\text { Volume of } \\
\text { removed } \\
\text { land }\left(\mathrm{m}^{3}\right)\end{array}$ & $\begin{array}{c}\text { Cost of } \\
\text { movement of } \\
\text { land(VND } \\
\text { million) }\end{array}$ & $\begin{array}{c}\text { Cost of } \\
\text { reconstruction } \\
\text { (VND } \\
\text { million) }\end{array}$ & $\begin{array}{c}\text { Landslide } \\
\text { damage cost } \\
\text { (VND } \\
\text { million) }\end{array}$ \\
\hline Tan Son & 10 & 150 & 3150 & 270.90 & 375.00 & 645.90 \\
Cum Pheo & 14 & 250 & 4500 & 531.00 & 625.00 & $1,156.00$ \\
Bao la & 23 & 100 & 2800 & 240.80 & 250.00 & 490.80 \\
Tan Dan & 38 & 100 & 2000 & 164.00 & 250.00 & 414.00 \\
Phuc San & 60 & 200 & 4800 & 412.80 & 500.00 & 912.80 \\
Ba Khan & 65 & 50 & 900 & 106.20 & 125.00 & 231.20 \\
Dong Bang & 69 & 100 & 2700 & 232.20 & 250.00 & 482.20 \\
Na Meo & 83 & 150 & 3150 & 258.30 & 375.00 & 633.30 \\
Thung Khe & 97 & 125 & 2250 & 265.50 & 312.50 & 578.00 \\
Van Mai & 113 & 50 & 1050 & 123.90 & 125.00 & 248.90 \\
\hline \multicolumn{1}{c}{ Total } & 10 & 1,275 & 27,300 & $2,605.60$ & $3,187.50$ & $5,793.10$ \\
\hline
\end{tabular}

Source: Own investigation and calculation

The results show that a total of 1,275 $\mathrm{m}$ of the road system was impacted by 10 landslides from 2000-2010. The landslide damage cost on roads was calculated by the cost of reconstruction these roads and the cost of movement of land triggered by landslides. The price to remove land and reconstruct the slide roads calculated based on the Decision No 2107/2007/QD-UBND stipulated by the president of Hoabinh Province. The cost to remove land ranged from $82,000 \mathrm{VND}$ to $118,000 \mathrm{VND}$ per $\mathrm{m}^{3}$ depending on the rock level in land. The cost of reconstruction was roughly 2.0 billion VND to 2.5 billion VND per $\mathrm{km}$. The table 5.8 shows that the total landslide damage cost on the road system was around 5.8 billion VND which also contributed significantly to the total landslide damage cost in the district.

\subsubsection{Costs of integration of landslide susceptibility into LUP}

According to Farber et al. (2002): Avoided Cost (AC) is defined as services that allow society to avoid costs that would been incurred in the absence of those services. For 
example: flood control avoids property damage or waste treatment by wetland avoids health costs. Avoided Cost is basically understood as an investment when the integration is conducted in the research area. In other ways, severe damages of landslides will be prevented or reduced, if an amount of money is invested in prediction of landslide susceptibility and integration component.

\subsubsection{Cost of making landslide component}

The cost of making Land Use Planning is actually stipulated by the Ministry of Natural Resources and Environment (MONRE) under land use types and rate of economic growth. The cost of the integration of the landslide risk component into Land Use Planning included:

Cost of data gathering: interview experts, authorities, officials at communes, district, province and others.

Cost of drawing the thematic maps, such as: slope, soil, vegetation cover, landslide susceptibility map and integrated map.

Cost of technical equipments: computer, the original maps. 
Table 5.10 Cost of making landslide component

\begin{tabular}{|c|c|c|c|c|}
\hline & Unit & Quantity & $\begin{array}{c}\text { Cost/unit } \\
\text { (VND 1000) }\end{array}$ & $\begin{array}{c}\text { Total cost } \\
\text { (VND 1000) }\end{array}$ \\
\hline \multicolumn{5}{|l|}{1 Interview } \\
\hline Province & Person & 7 & 150 & 1,050 \\
\hline District & Person & 10 & 120 & 1,200 \\
\hline Commune & Person & 92 & 100 & 9,200 \\
\hline Others & Person & 30 & 150 & 4,500 \\
\hline \multicolumn{5}{|l|}{2 Drawing map } \\
\hline Soil & Map & 1 & 15,000 & 15,000 \\
\hline Slope & Map & 1 & 30,000 & 30,000 \\
\hline Vegetation cover & Map & 1 & 15,000 & 15,000 \\
\hline Landslide susceptibility & Map & 1 & 30,000 & 30,000 \\
\hline Integrated map & Map & 1 & 30,000 & 30,000 \\
\hline \multicolumn{5}{|l|}{3 Equipment } \\
\hline Computer & & $1 / 4$ & 20,000 & 5,000 \\
\hline DEM & Map & 1 & 20,000 & 20,000 \\
\hline Total & & & & 160,950 \\
\hline
\end{tabular}

Source: Own investigation and calculation

Cost of drawing map, equipment and interview was collected at company of agricultural services at Hanoi University of Agriculture, A Chau Ltd Company in Hanoi and Hoabinh Province. In addition, the price was as well relied the stipulation of the Ministry of Natural Resources and Environment in Decree No 31/2005/ND-CP (in 2005), Decision No 04/2005/QD-BTNMT (in 2005), Decision No 10/QD-BTNMT (in 2005), Circular No 04/2007/TTLT/BTNMT-BTC (in 2007) and based on the coefficient of salary of interviewees that were stipulated by the Government. The results in table 5.10 show that the total cost needed to do the integration of landslide susceptibility into LUP was roughly m161 VND including cost of interview, drawing the maps and equipments. 


\subsubsection{Cost of change the residential locations and agricultural crops.}

The incorporation of landslide susceptibility into LUP resulted in additional restrictions for the spatial allocation of land uses. If integrated LUP had already been available in the year 2000, some settlements would not have been allowed to be built. These settlements would have been built elsewhere. Still these locations may have a higher cost compared to the actual one. These changes can be expected to be costly. These costs need to be quantified.

\section{Cost of change $=$ Cost of new location - Cost of actual location}

Cost of change: In comparison with the old LUP, some planned areas for residential area need to be located in other places. The land's price is possibly different between two places, so the changes may to be costly. Also the location with reference to the agricultural fields may be worse, or construction is more expensive because the ground is less suitable.

Cost of new location: The land's price in the alternative place would be considered, if LUP was integrated by landslide susceptibility.

Cost of old location: The price of land in the place at the actual location was calculated. Because the integration was not carried out, the place was actually slid by landslides.

The results of the landslide damage analysis from 2000 to 2010 show that a total of 19 landslides affected the residential land in Maichau District. Of which 12 landslides were labeled as high susceptibility in landslide prediction and low suitability in the integrated map. These affected areas were actually resettled in the new places. If the integration was carried out, these affected locations would have to move to new places with better conditions than in actual locations. According to LUP in 2000, the total residential area will increase 104.83 ha from 2000 to 2010. In which 46.13 ha occurs correctly on high level of landslide susceptibility. If the integration was conducted, this area would change to the new places as well. Cost of the change shows in table 5.11 
Table 5.11 Cost of change the residential locations

\begin{tabular}{|c|c|c|c|c|c|c|}
\hline ID (landslide) & $\begin{array}{c}\text { Place } \\
\text { (where) }\end{array}$ & $\begin{array}{c}\text { Affected } \\
\text { area } \\
\text { labeled } \\
\text { as lowly } \\
\text { suitable } \\
\left(\mathrm{m}^{2}\right)\end{array}$ & $\begin{array}{l}\text { Land's } \\
\text { price in } \\
\text { old place } \\
(\mathrm{VND} \\
\left.1000 / \mathrm{m}^{2}\right)\end{array}$ & $\begin{array}{c}\text { Land's } \\
\text { price in } \\
\text { new } \\
\text { place } \\
(\mathrm{VND} \\
\left.1000 / \mathrm{m}^{2}\right)\end{array}$ & $\begin{array}{c}\text { Difference } \\
(\mathrm{VND} \\
\left.1000 / \mathrm{m}^{2}\right)\end{array}$ & $\begin{array}{c}\text { Total cost } \\
\text { (VND } \\
1000)\end{array}$ \\
\hline 2 & $\mathrm{PaCo}$ & 400 & 50 & 80 & 30 & 12,000 \\
\hline 3 & Xa Linh & 308 & 35 & 70 & 35 & 10,780 \\
\hline 4 & Hang Kia & 300 & 30 & 50 & 20 & 6,000 \\
\hline 56 & Suoi Lam & 1,000 & 35 & 50 & 15 & 15,000 \\
\hline 58 & $\mathrm{Go} \mathrm{Mu}$ & 1,400 & 60 & 80 & 20 & 28,000 \\
\hline 61 & Xom Bang & 700 & 60 & 390 & 330 & 231,000 \\
\hline 67 & Xom Vat & 400 & 60 & 200 & 140 & 56,000 \\
\hline 68 & Xom Vat 2 & 320 & 60 & 200 & 140 & 44,800 \\
\hline 76 & Xom Tong & 1,200 & 110 & 200 & 90 & 108,000 \\
\hline 101 & Cha Day & 400 & 30 & 50 & 20 & 8,000 \\
\hline 104 & Cha Day & 800 & 30 & 50 & 20 & 16,000 \\
\hline 116 & Thanh Mai & 1,200 & 55 & 160 & 105 & 126,000 \\
\hline Total & & 8,428 & \multicolumn{2}{|c|}{ Weighted average } & 78 & 661,580 \\
\hline \multicolumn{2}{|c|}{ Integrated LUP } & 461,300 & Weigh & ed average & 78 & $35,973,600$ \\
\hline
\end{tabular}

Source: Own investigation and calculation

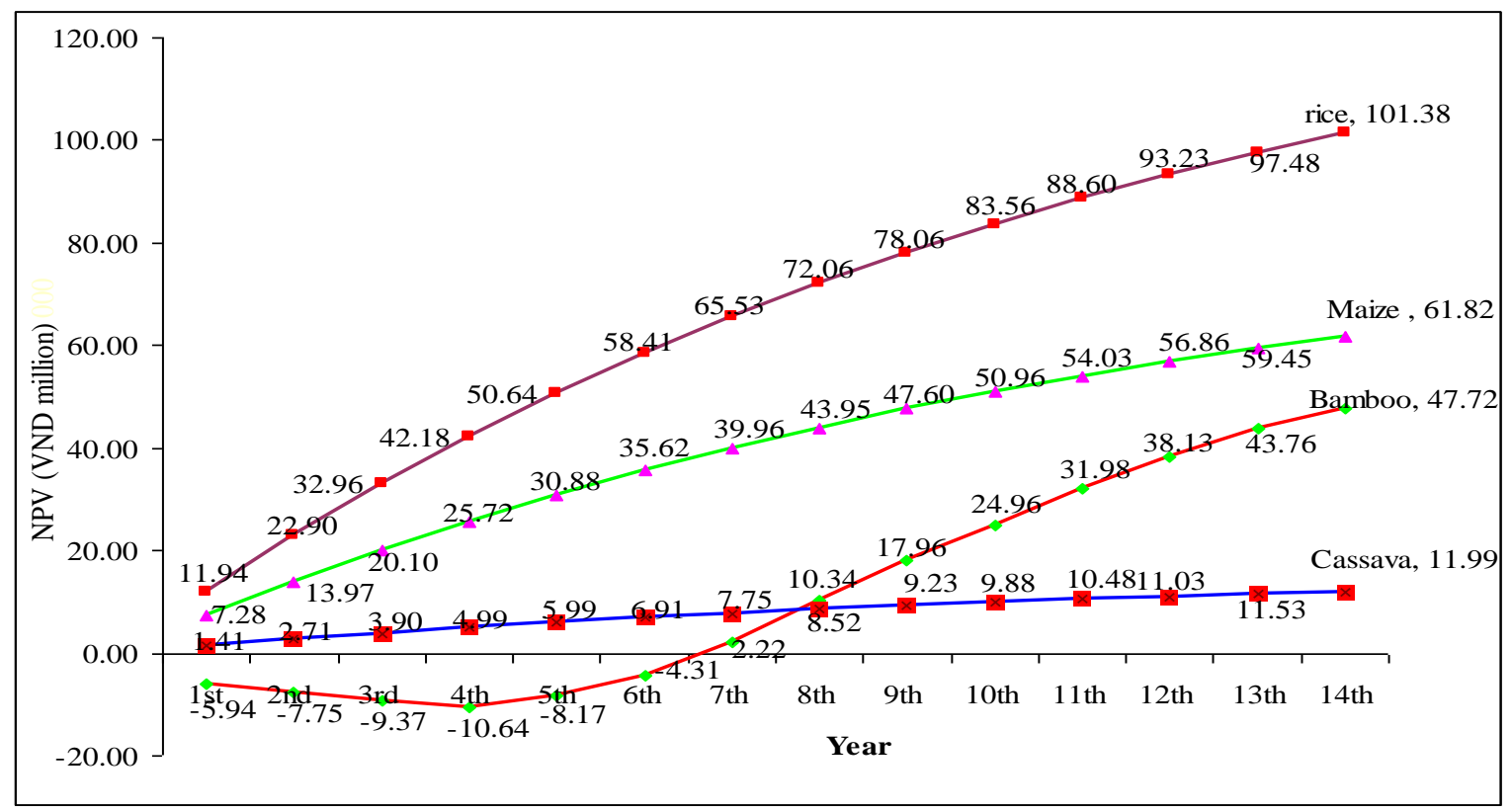

Fig.5.8 Comparison NPV between agricultural crops and bamboo 


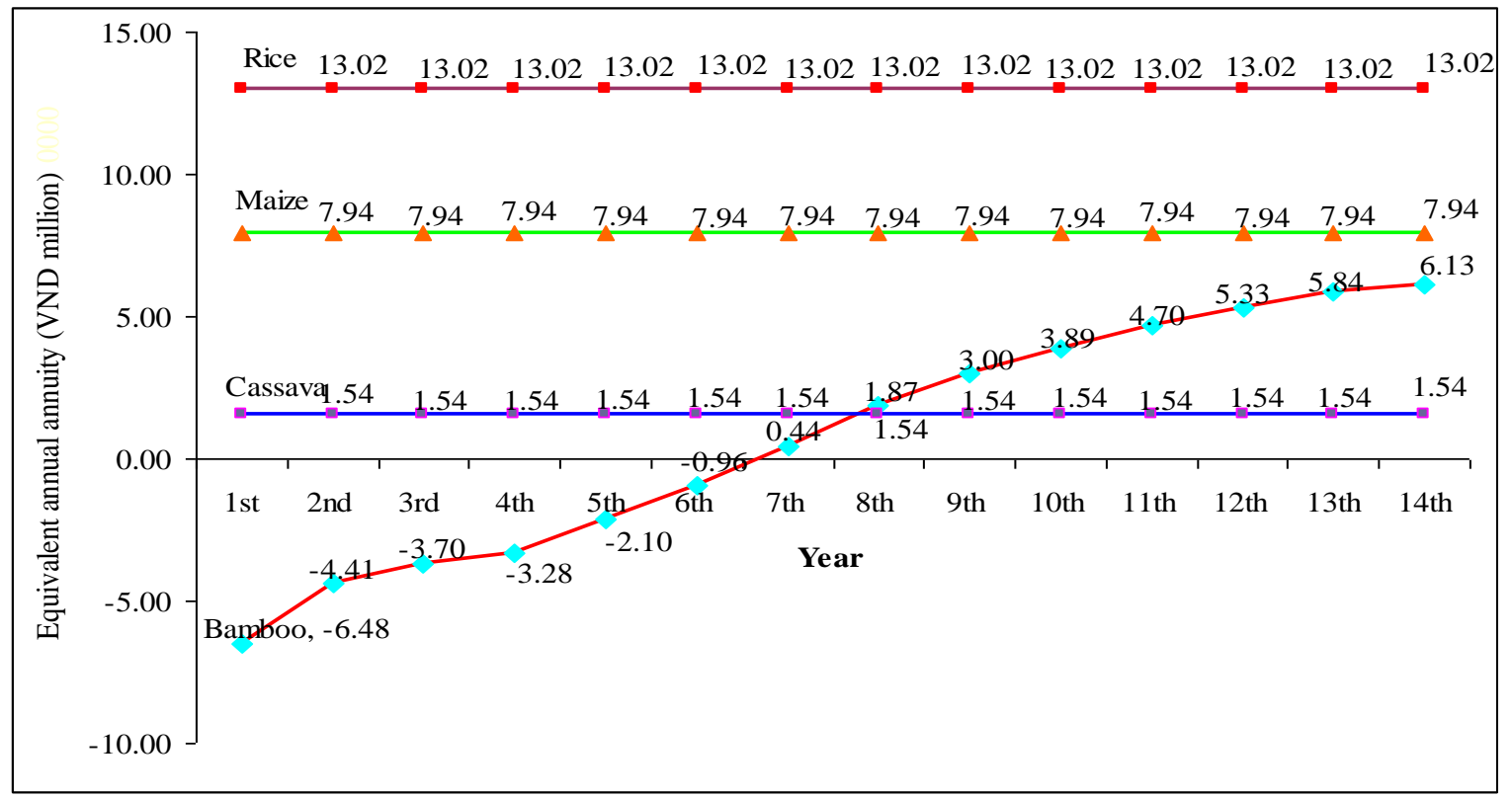

Fig.5.9 Comparison net income between agricultural crops and bamboo

Table 5.12 Loss of land use change from agriculture to forest for the period of 14 years

\begin{tabular}{|c|c|c|c|c|c|}
\hline $\begin{array}{l}\text { Agricultural } \\
\text { crops }\end{array}$ & $\begin{array}{c}\text { Area } \\
\text { labeled } \\
\text { lowly } \\
\text { suitable } \\
\left(\mathrm{m}^{2}\right) \\
(2)\end{array}$ & $\begin{array}{l}\text { Net income } \\
\text { of } \\
\text { agriculture } \\
\text { (VND } \\
\left.1000 / \mathrm{m}^{2}\right) \\
(3)\end{array}$ & $\begin{array}{l}\text { Net income } \\
\text { of forest } \\
\text { (VND } \\
\left.1000 / \mathrm{m}^{2}\right) \\
\text { (4) }\end{array}$ & $\begin{array}{l}\text { Difference } \\
(\mathrm{VND} \\
\left.1000 / \mathrm{m}^{2}\right) \\
(5=3-4)\end{array}$ & $\begin{array}{c}\text { Total loss } \\
\text { (VND 1000) }\end{array}$ \\
\hline Rice & 77,803 & 18.20 & 8.54 & 9.66 & 751,576 \\
\hline Maize & 288,200 & 11.06 & 8.54 & 2.52 & 726,264 \\
\hline Cassava & 71,000 & 2.10 & 8.54 & -6.44 & $-457,240$ \\
\hline Total & 437,003 & \multicolumn{2}{|c|}{ Weighted average } & 2.33 & $1,020,600$ \\
\hline Integrated LUP & $20,187,300$ & \multicolumn{2}{|c|}{ Weighted average } & 2.33 & $47,036,409$ \\
\hline
\end{tabular}

Source: Own investigation and calculation

The table 5.11 indicates that when landslides happened, the affected locations were actually resettled in the new places. The land's price of the old place and new place was investigated in the communes (detail in section 5.3.2.3). Basically, the land's price in the new places was usually higher than in the old places because of better geophysical and socio-economic conditions. As the slid areas normally situated in high and complicate terrains and resettled areas were, however, better, so that the differences of the price 
between two places were calculated. Total cost of the changes of 12 residential locations affected by actual landslides was nearly m662 VND. If the integration had been implemented, total cost of the change 46.13 ha of residential areas would have been 35.97 billion VND. If local people and government invested in this work in 2000, they would not have received the severe impacts from landslides on the residential areas.

Additionally, the change of some agricultural land use types would be considered if the integration was applied. Indeed, rice, maize and cassava crops labeled as unsuitable or lowly suitable should be changed into forest. Actually, if this scenario was done, the land users would lose the different net income between agriculture and forest. In other words, they would lose the difference between agriculture's net income and forest's net income, if the changes from agricultural crops to forest were implemented. The difference was calculated for the total rotation of cultivation (14 years).

According to own investigation, all the interviewed households answered that if they have support for changing from agriculture to forest, they will change to bamboo, although annual income of bamboo is normally lower. As reasons for their choice, they explained for example: (1) bamboo does not have to be replanted as often as acacia (longer rotation period); (2) lower initial investment for bamboo than for acacia at the beginning of the rotation; (3) local market for bamboo is better that for acacia.

NPV (Net Present Value) and EAA (Equivalent Annual Annuity) were calculated by equations (5) and (6). The fig.5.8 shows that NPV of rice was the largest with nearly m101 VND. The lower was maize standing at m62 VND and especially NPV of bamboo was merely m48 VND, higher than cassava with m12 VND. The fig.5.9 indicates the difference of EAA between agricultural crops and bamboo. If the change from rice crop to bamboo was realized, the difference or the loss of change would be nearly m7.0 VND ha ${ }^{-1}$ year $^{-1}$. Similarly, the loss of change from maize to bamboo would be m1.8 VND ha ${ }^{-1}$ year $^{-1}$. In contrast, when the change from cassava to bamboo was conducted, the land users would gain m4.6 VND ha ${ }^{-1}$ year ${ }^{-1}$. Generally, the total loss of change from agricultural crops to bamboo for the rotation of 14 years shown in the table 5.12 could be roughly 1.02 billion VND for actual landslides from 2000 to 2010. Based on the overlapping between landslide susceptibility and LUP, total agricultural area estimated as unsuitable or lowly suitable was 2018.73 ha. If the integration was implemented in 2000, the loss of change this agricultural 
area to bamboo would be 47.04 billion VND.

To sum up, the total cost of change the residential locations and change the agricultural land to plant bamboo would be 83.01 billion $\mathrm{VND}$, if the integration of landslide susceptibility into LUP was implemented in the research area. Finally, the total cost of the integration including: cost of landslide prediction, cost of change the residential locations and loss of change the agricultural crops to bamboo would be 83.17 billion VND.

\subsubsection{Results}

Total economic damage caused by landslides would be possibly rejected or diminished if the landslide prediction and the integration were carried out. In the research area, because the prediction and integration were not conducted in 2000 , the cost and potential net income of land users were lost by actual landslides. Based on the equations (2), avoided landslide damage cost on agriculture, forest, residential area and the road system, the avoided landslide damage cost of each landslide was calculated. After that total avoided landslide damage cost was determined by equation (2). Total landslide damage cost was also calculated by equation (1). The results are shown in appendix 6 and fig.5.10.

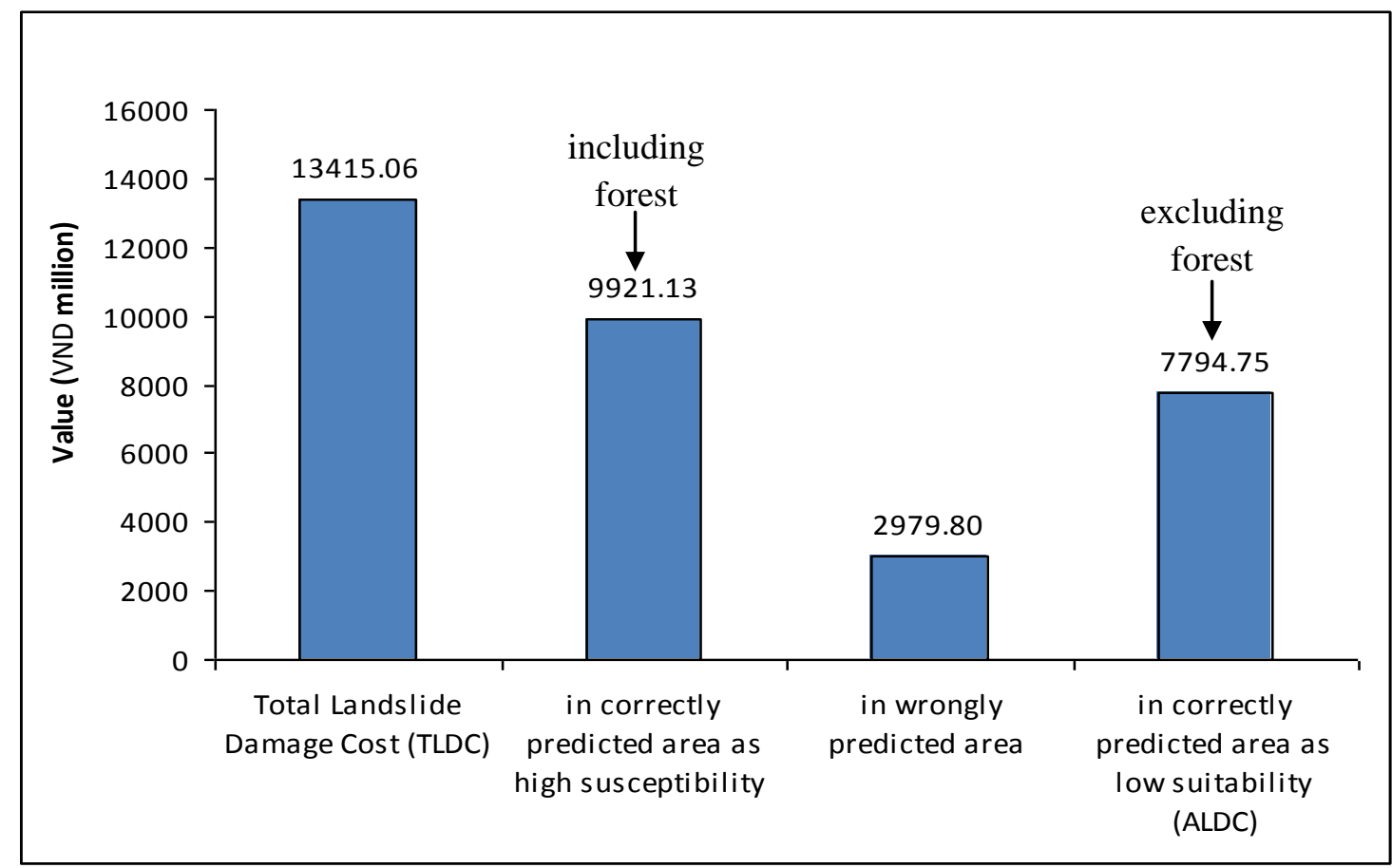

Fig.5.10 Landslide Damage Cost in Maichau District 
The data shows that Total Landslide Damage Cost (TLDC) was 13.42 billion VND, of which roughly 74\% (9.92 billion VND) happened correctly on high level of landslide susceptibility. And 22\% (2.98 billion VND) of TLDC was determined as moderate susceptibility. The damage on deaths in monetary term was m541.14 VND. In addition, 7.79 billion VND of TLDC was labeled as unsuitable or lowly suitable when the integration was conducted. Thus, nearly $80 \%$ of TLDC labeled as high susceptibility was estimated as wrong or unsuitable for some land use types in LUP, including: Agriculture, residential land, and road system. If landslide susceptibility was integrated into LUP, some unsuitable land use types on highly susceptible areas should be changed into others in LUP, such as: Annual crops to forest and the change of the residential locations. Consequently, this damage (ALDC) would be avoided by the integration activity.

The costs included the cost of landslide prediction, the cost of change the residential locations and the loss of change from agricultural crops to forest. The benefit was the Avoided Landslide Damage Cost (ALDC).

According to the simple cost benefit model in section 5.3.1, the Avoided Landslide Damage Cost and costs of integration, net benefit of the integration was calculated and shown in fig.5.11.

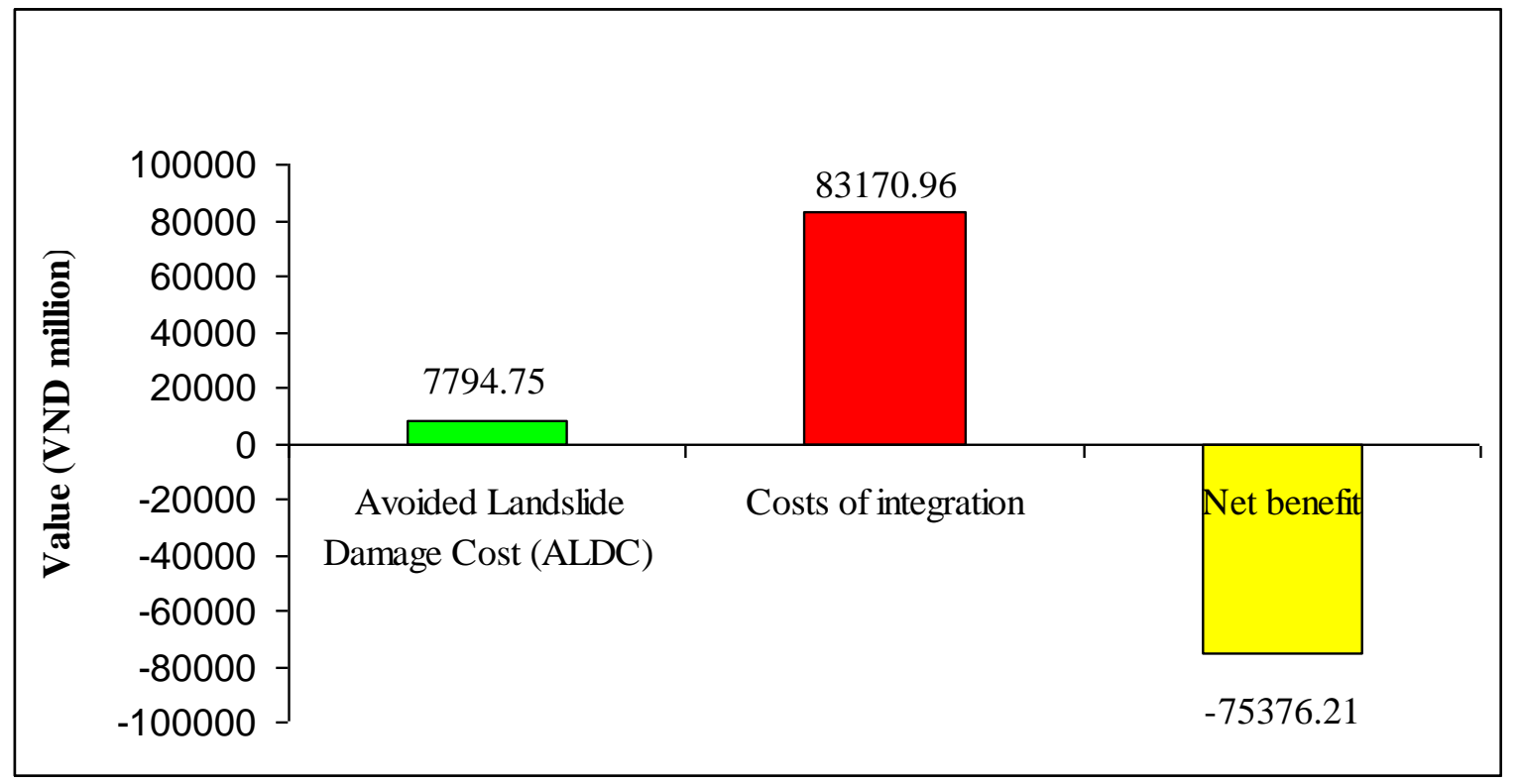

Fig.5.11 Net benefit of the integration of landslide susceptibility into LUP

The fig.5.11 demonstrates that net benefit of integration was -75.38 billion VND in 
comparison with the costs of roughly 83.17 billion VND.

\subsection{Conclusions and discussions}

The impact of the landslides on the district's economy was quite large. Nearly 3\% of Maichau's GDP in 2010 (422 billion VND (GSO Mai Chau, 2010) ) was lost to landslides. With annual GDP per capita m8.0 VND (GSO Mai Chau, 2010), the landslides in the past 10 years caused the loss of income of around 1,600 inhabitants or roughly 350 households. Local people and the district's economic situation were, therefore, burdened substantially with landslide damage cost. Furthermore, others damages of landslides likely affected the living conditions of local people, such as: transportation problems caused by road damages or reduced or degraded water supply.

Of the 122 landslide events that happened in the research area from 2000-2010, 77\% of the landslide events and of the area occurred where the AHP model has indicated a high level of landslide susceptibility. Thus, the coverage of actual landslides, i.e. one important aspect of the empirical validity of the model, can be regarded as satisfactory to good. In other words, about $77 \%$ of the landslides could be predicted correctly by the landslide model - before any calibration using actual landslide data.

In terms of the landslide damage analysis, the effect on the road system was very large. Because of lack of expertise, I did not investigate the costs of relocating traffic infrastructure. My data can be used here, however, as a starting point for more detailed investigations. For example, a future LUP may suggest to plant forest trees on the high areas along to the roads and built special constructions on the high susceptibility areas to protect the road system.

At the level of detailed results, the landslide damage analysis demonstrates that the damage on rice crop was the greatest, followed by maize and cassava. For forest, if landslides happen in the year ${ }^{+7}$ for acacia and year ${ }^{+6,+7,+8}$ for bamboo, the damage will be the largest. This finding is meaningful for land users and authorities to propose proper solutions to protect forest trees in the vital periods of the forest rotation and the annual crops.

The integration of landslide susceptibility into the LUP 2000 map indicates that roughly 
$6.3 \%$ area of the district was assigned an "unsuitable" land use type. The location and extent of this area is related directly to the AHP landslide model. Consequently, location and area are impacted by the numerous instances of expert judgments as already explained in detail in previous sections. For these $6.3 \%$, the current integration of landslide risks into the LUP 2000 map implies the recommendation to assign a different land use type to the affected areas. Mainly, residential and agricultural use would be assigned to forestry use instead.

In Vietnam, $90 \%$ of poor households live in the rural areas with the poorest living in the mountainous upland areas (Cuong, 2005b: p12). The capital of local farmers is limited; they basically rely on local land resources. In addition, local food security depends greatly on access to land for agricultural activities (Cuong, 2005a: p327; Duong \& Izumida, 2002; Mueller, 2003: p85). Thus, any planning decision that reduces the access of local households to agricultural land and/or burdens them with changes to traditional settlement structures needs to be investigated very carefully. If implemented in an insensitive manner, changes of land use from agricultural crops to forest to diminish the landslide damages may result in food shortage, deepen poverty, and may even reduce the opportunities of the young generation as income for better education becomes increasingly scarce.

Some negative economic aspect of converting agricultural land to bamboo plantations can rather simply by accomplished, at least in theory. According to my own investigation, bamboo harvesting normally begins in the $5^{\text {th }}$ year, and acacia harvesting in the $7^{\text {th }}$ year. This means that the households have to invest and wait for several years before the plantations generate any income. Here, loan or subsidy programs can substantially reduce the conversion burden for local household giving up annual crops.

If the integration between LUP and landslide susceptibility is regarded from an economic perspective, the cost of the integration using the current models, data and algorithms are very high, actually, resulting in a negative net benefit. The negative net benefit documented relates directly to the results of the non-calibrated landslide model: The cut off points between landslide susceptibility categories suggest themselves for optimizing the balance between land declared as unsuitable for high-value land use and land declared as moderately suitable. Attempts to tighten the cut-off point may improve the economic performance of the integration. However, it may also result in lower landslide risk 
protection, an increase in deaths and injuries, and higher damage to the transportation system. Even with substantially negative net benefit, planners/ politicians may choose a precautionary approach to landslide risks. Still, it would remain an important analytical task to improve the current integration to the point that the net benefit is as little negative as possible or even positive. 


\section{CHAPTER 6: GENERAL CONCLUSIONS AND RECOMMENDATIONS}

\subsection{General conclusions}

The key objective of this study is to improve the quality of LUP by the integration of landslide susceptibility. This is a highly relevant topic as landslides are often triggered by severe weather conditions or earthquakes, but landslide frequency and severity are often amendable to improve land use. Vietnam is one of the countries in the world impacted severely by climate change. By increasing the severity of weather conditions potentially triggering landslides, climate change additionally stresses the importance of predicting and reducing landslide damages. This reduces some of the uncertainties that - according to Smith (2010: p62-73) hamper effective social investment decision relating to climate change.

In chapter 2, the certain correlation of Land Use Planning and socio-economic development was established. The changes of some land use types in LUP 2000 were positively correlated to socio-economic development at the municipality level. For example, the increase of annual crop land correlated with the increase of food production. Also, the increase of residential land was correlated to population growth. Likewise, industrial development is a very important development aim in Vietnam, and an increase of land for business and industry was correlated with labour use in the non-agricultural sector. Thus, there is the expectation that improved Land Use Planning will actually translate into improved land use on the ground. Most importantly, I could document that the planned changes to land use (LUP 2000) are correlated to the actual land use changes observed between 2000 and 2010.

To determine landslide susceptibility in Maichau District, some criteria were chosen, namely: slope, soil types, soil texture, soil depth and vegetation cover. These criteria were selected and assessed based on the actual conditions of research area, and based on expert opinions that I used as background knowledge in construction of the AHP landslide susceptibility model. Slope and vegetation cover were judged as the most important to predict the landslide susceptibility in the research area. The specific selection of the criteria and their weight may be different in other research areas. Still, the general procedures used are expected to be transferable.

With these criteria, the each 30x30 m pixel of a map of Maichau District was classified with respect to its landslide susceptibility: low, moderate or high. The cut off point 
between these categories also depends on my analyst judgment based on the consultation of local, regional and national experts. This kind of expert knowledge is a key point leading to the quality of landslide model. The results show that roughly $3 \%, 62 \%$ and $35 \%$ area of the district were predicted at low, moderate and high level of landslide susceptibility. In a further step of the analysis, I determined to which extent the resulting landslide susceptibility model accurately predicted the landslides in Maichau District from $2000-2010$.

By the integration of landslide susceptibility into LUP 2000, roughly $6.3 \%, 90.7 \%$ and $3 \%$ area of the district were assessed as lowly, moderately and highly suitable for the land use types assigned to the pixel by LUP 2000. In particular, $6.3 \%$ area of the district was labeled as unsuitable for agriculture, residence, infrastructure and unused land. If the integration exactly according to the current, non-calibrated model was carried out in 2000, the land use types would have been changed for these areas to reduce the damages of landslides. Basically, these rather high value land use types (exception: unused) would have been assigned forestry use.

The 122 landslide events that happened from 2000-2010 in Maichau District impacted a total area of around 114 ha, in which 56.3 ha was of agriculture, 55.4 ha of forest, 1.5 ha of residence and 0.8 ha of road. Roughly $77 \%$ of the landslide events and affected area occurred correctly predicted on high level of landslide susceptibility. Of which, an area of about 45 ha was assessed as lowly suitable when the overlapping between actual landslides and integrated map was conducted. Therefore, if the prediction of landslide susceptibility had been realized in 2000, $77 \%$ of landslide events and affected area would have probably been anticipated on the high level of landslide susceptibility. It is an acceptable or even good performance of this landslide risk model itself.

Actual damage of the landslides on the research district's economy and local people was quite large with a peak in 2007. If the integration of landslide susceptibility according to the current model had been conducted in 2000 - and perfectly implemented, a total damage of 13.4 billion VND could have been avoided.

A simplified cost benefit analysis of the integration indicates that the cost of changing the LUP 2000 and implementing an "improved" LUP would have been quite large. In fact, the cost of changing the unsuitable spatial extension of settlements and the loss caused by 
changes of agricultural area to bamboo plantations contributed the largest shares to total cost of the integration (nearly 83.2 billion VND). The resulting net benefit was negative amounting to 75.4 billion VND. Based on the economic point of view, the integration as it stands is not efficient.

Given the technical applicability of an AHP-based integration of landslide risks into Land Use Planning in Vietnam at the district level, the question arises if this poor economic performance of the current model can be improved. This is most certainly the case. Although the respective calibrations could not be conducted within the frame of this study, a systematic optimization the cut-off points of the landslide risk analysis suggests itself. At this point it cannot be judged if such an optimization will result in a positive net present value of an improved integration. Even a somewhat negative NPV may be acceptable to regional decision-makers given the fact that costs may have been underestimated and that human life is at stake.

\subsection{Recommendations and policy implications}

Based on the findings of this study, the following policy implications and recommendations may be formulated:

The research findings indicated that LUP correlates with socio-economic development, and tended to meet the changes of Maichau District's society from 2000 to 2010. Contents and processes of LUP need to continue to consult economic strategy development in the long term, and to respond to the results of actual economic development in the previous period.

Against the threat of negative climatic impacts on natural hazards such as landslides induced by climate change, the minimization the natural hazard damage may even rise as an important concern for local people, planners, and authorities. Integration of environmental phenomena such as landslides, drought, flooding into LUP should be considered in different levels from the national level to the commune.

Land use change, especially changing from agricultural land to forest land (bamboo plantations) is suggested for land threatened by landslides in Maichau District. An implementation of these land use changes probably needs some forms of public support in 
the first 5 years of forest rotation. Also support for planting forest on unused land should be considered.

In particular, dealing with the food production and land use issues in mountains should be considered carefully by government, administration and other organizations as not to destabilize local communities. The extent to which local land users are ushered into changing their actual land use to reduce landslide risks should, thus, be carefully considered on economic grounds as - even with some income support - average long-term incomes may be reduced. Thus, no administrative action should be taken based on the current landslide risk model, (i) unless the LUP integration algorithm is much improved to yield an acceptable net present value, and (ii) fully acknowledging the right of the local communities and households to their individual judgments how they balance landslide risk versus loss of income from the affected land.

Actually, fluctuation of environmental factors also affects significantly the natural resources management not only in Vietnam, but also world-wide. However, this study is one of the first researches as an integration of landslide risk into Land Use Planning in Vietnam, in particular the first with simplified Cost Benefit Analysis approach. Thus, to prove the contribution of this study in the contents and processes of LUP and policy, more researches with AHP method need to carry out in other districts. Furthermore, more researches to economically optimize landslide risk integration for Land Use Planning need to conduct as well in Vietnam. 


\section{REFERENCES}

Ahlheim, Michael, Oliver Frör, Antonia Heinke, Nguyen Minh Duc, \& Pham Van Dinh. (2010). Labour as a utility measure in contingent valuation studies - How good is it reality? FZID Discussion Papers. Universität Hohenheim, 13.

Ahlheim, Michael, Oliver Frör, Antonia Heinke, Alwin Keil, Minh Duc Nguyen, \& Van Dinh Pham. (2008). Landslides in mountainous regions of Northern Vietnam: Causes, protection strategies and the assessment of economic losses Hohenheimer Diskussionsbeiträge aus dem institut für volkswirtschafslehre der Universität Hohenheim.

Ahn, Byeong Seok. (2000). The analytic hierarchy process in an uncertain environment: A simulation approach by Hauser and Tadikamalla (1996). European Journal of Operational Research, 124, P217-218.

Albecht, Dieter, Elke Eller, Angelika Fledderman, Karin Janz, WieLand Kunzel, \& Robert Riethmuller. (1996). Experience of land use planning in Asian projects: Selected insights. : The working group on land use planning for the Asian-Pacific Region.

Almansa, Carmen, \& José .M Martínez-Paz. (2011). What weight should be assigned to future environmental impacts? A probabilistic cost benefit analysis using recent advances on discounting. Science of the Total Environment, 409, p1305-1314.

Amler, B, D Betke, H Eger, C Ehrich, A Kohler, A Kutter, et al. (1999). Land Use Planning: Methods, Strategies and Tools: Deutsche Gesellschaft für Technische Zusammenarbeit (GTZ) GmbH.

Anagnostopoulos, K. P., \& A. P. Vavatsikos. (2006). An AHP Model for Construction Contractor Prequalification. Operational Research. An International Journal, 6(3), P333-346.

Anonymous. (1992). Constitution of the Socialist Republic of Vietnam. In Vietnam National Assembly (Ed.). 
Anonymous. (1999). Soil map of Maichau District, Hoabinh Province: The Institute of Agricultural Planning.

Anonymous. (2000). Land inventory in 2000: People's committee of Maichau District.

Anonymous. (2001). The report on land use planning of Maichau District - Hoabinh Province: People's committee of Maichau District.

Anonymous. (2003). The Vietnam Landlaw in 2003. In Vietnam Government (Ed.).

Anonymous. (2006). Assessment policy and management for land use planning and proposed active plan in Vietnam: The Vietnam-Swiden cooporation programme of Strengthening environmental management and land administration in Vietnam.

Anonymous. (2010a). The annual report on socio-economic development in 2010 of Maichau district, Hoabinh Provimce: People's committee of Maichau District.

Anonymous. (2010b). Digital Elevation Model (DEM) of Maichau District, Hoabinh Province: Vietnam Ministry of Natural resources and Environment.

Anonymous. (2010c). General demographic investigation 2009 in Vietnam Hanoi: Vietnamese government.

Anonymous. (2010d). Land inventory in 2010: People's committee of Maichau District.

Anonymous. (2010e). Professional guideline of land use inventory and mapping current land use in 2010: Vietnam Ministry of Natural Resources and Environment.

Anonymous. (2010f). Traffic system statistics in 2010 in Maichau District: The Department of transportation in Maichau District, Hoabinh Province.

Antonio, Di Gregorio, \& J. M. Jansen Louisa. (2005). Land cover classification system: Classification concepts and user manual. Software version 2.0. Food and agriculture Oganization of the United Nation, Rome.

Ayalew, Lulseged, \& Hiromitsu Yamagishi. (2005). The application of GIS-based logistic regression for landslide susceptibility mapping in the Kakuda-Yahiko Mountains, Central Japan. Geomorphology, 65, P15-31. 
Baniya, Nabarath. (2008). Land suitability evaluation using GIS for vegetable crops in Kathmandu valley/ Nepal. Humboldt-Universität, Berlin.

Bhushan, Navneet, \& Kanwal Rai. (2004). Strategic decision making: Applying the Analytic Hierarchy Process: Springer.

Boardman, Anthony. E, David. H Greenberg, Aidan. R Vining, \& David. L Weimer. (2006). Cost - Benefit Analysis: Concepts and Practice (Vol. Third Edition): Pearson Prentice Hall. Upper Saddle River, New Jersey 07458, USA.

Bristow, M. Roger. (1981). Planning by demand: A possible hypothesis about town planning in Hong Kong. Asian journal of public administration, 199-223.

Burrough, P.A. (1986). Principles of geographical information systems for land resources assessment. New York: Oxford University press.

Cambell, Scott. (1996). Green cities, growing cities, just cities? Urban planning and the contradictions of sustainable development. Journal of the american planning association 62., P 269-313.

Cecilia, Valencia-Sandoval, N. Flanders David, \& A. Kozak Robert. (2010). Participatory landscape planning and sustainable community development: Methodological observations from a case study in rural Mexico. Land Use Policy 94, P63-70.

Chaco’n, J., T. Irigaray, T. Ferna’ndez, \& R. El Hamdouni. (2006). Engineering geology maps: landslides and geographical information systems. Bull Eng Geol Environ, 65, P341-411.

Chau, K. T., Y. L. Sze, M. K. Fung, W. Y. Wong, E. L. Fong, \& L. C. P. Chan. (2004). Landslide hazard analysis for Hong Kong using landslide inventory and GIS. Computers \& Geosciences, 30(4), 429-443.

Chau, K. T., Y. L. Sze, M. K. Fung, W. Y. Wong, E. L. Fong, \& L. C. P. Chan. (2004). Landslide hazard analysis for HongKongusing landslide inventory and GIS. Computers \& Geosciences, 30, 429-443. 
Chieu, Ton That, Le Thai Bat, Nguyen Khang, \& Nguyen Van Tan. (1999). Manual Survey, Classification and Land Evaluation. Hanoi, Vietnam: Agricultural Publisher.

Circular No 08. (2007). Guideline of land use statictic and inventory and mapping current land use: Vietnam Ministry of Natural Resources and Environment.

Circular No 19. (2009). Detail provisions on land use planning In Vietnam Ministry of Natural Resources and Environment (MoNRE) (Ed.).

Conroy, Maria Manta, \& Philip R. Berke. (2004). What makes a good sustainable development plan? An analysis of factors that influence principles of sustainable development. Environment and planning A 36, P1381-1396.

Counsell, Dave, \& Graham Haughton. (2006). Sustainable development in regional planning: The search for new tools and renewed legitimacy. Goeforum 37, P921931.

Crowley, John .R, John .L Hall, E. Bruce MacDuogall, John Passarello, \& Frederick .J Thomson. (1975). Land use planning. Supporting paper 3.

Cruden, D. M. (1991). A simple definition of a landslide. Bulletin of the International Association of Engineering Geology, 43, 27-29.

Cuong, Pham Manh. (2005a). Land-use change in the Northwestern uplands of Vietnam. Georg-August University, Goettingen, Germany.

Cuong, Tran Huu. (2005b). Market Access and Agricultural Production in Vietnam. University Hohenheim.

Dai, Do Dinh, Nguyen Thanh, Nguyen Thanh Xuan, Lam Quang Hinh, \& Nguyen Thanh Thong. (2009). Land Use and Management at the district. Hanoi, Vietnam: Scientific and Technical Publisher.

Dai, F. C., C. F. Lee, J. Li, \& Z. W. Xu. (2001). Assessment of landslide susceptibility on the natural terrain of Lantau Island, Hong Kong. Environmental Geology 40, p381391. 
Dai, F. C., C. F. Lee, \& Y. Y. Ngai. (2002). Landslide risk assessment and management: an overview. Engineering Geology, 64(1), 65-87.

Decision 20. (2007). Norm on ecomic-technical standard of land use inventory and mapping current land use: Vietnam Ministry of Natural resources and Environment.

Decree No 69. (2009). Additional provisions on land use planning, land prices, land acquisition, compensation, support and resettlement. In Vietnam Government (Ed.).

Demoulin, Alain, \& Chang-Jo F. Chung. (2007). Mapping landslide susceptibility from small datasets: A case study in the Pays de Herve (E Belgium). Geomorphology, 89, P391-404.

DETR. (2000). Building better quality of life: A strategy for more sustainable development. London: Department of the Environment, Transport and the Regions.

Dien, Pham Van. (2006). Proposal of appropriate structure model for mixed bamboo and wood forest in Binh Hem cummune, Lan Thuy District, Hoa Binh Province. Journal of Agriculture and Rural development., 1, p37-39.

Dinkel, Rolf H. (1985). Cost-benefit analysis: a helpful tool for decision makers? Health Policy, 4, p321-320.

Directive No 24. (1999). Total land use inventory in 2000: Vietnam Government.

Directive No 618. (2009). Land use inventory and mapping current land use in 2010: Vietnam Government.

Doeleman, Jacobus A. (1985). Historical perspective and environmental cost-benefit analysis. Futures, 17(2), p149-163.

Domínguez-Cuesta, María José, Montserrat Jiménez-Sánchez, \& Edgar Berrezueta. (2007). Landslides in the Central Coalfield (Cantabrian Mountains, NW Spain): Geomorphological features, conditioning factors and methodological implications in susceptibility assessment. Geomorphology, 89(3-4), 358-369.

Downton, Mary. W, \& Roger A. Pielke. (2005). How Accurate are Disaster Loss data? The case of U.S. Flood Damage. Natural Hazards, 35, P211-228. 
Duc, Tran Trong. (2006). Using GIS and AHP technique for land use suitability analysis. International Symposium on Geoinformatics for Spatial Infrastructure Development in Earth and Allied Sciences.

Dung, Bui Thi Ngoc, Do Dinh Dai, Tran An Phong, Nguyen Thi Hien, Nguyen Thanh Xuan, Nguyen Thanh, et al. (2009). Land Classification and Evaluation. Hanoi, Vietnam: Scientific and Technical Publisher.

Duong, Pham Bao, \& Yoichi Izumida. (2002). Rural Development Finance in Vietnam: A Microeconometric Analysis of Household Surveys. World Development, 30(2), p319-335.

Elvik, Rune. (2001). Cost-benefit analysis of road safety measures: applicability and controversies. Accident Analysis and Prevention, 33, p9-17.

Enemark, Stig, \& Hans Sevatdal. (1999). Cadastres, Land Information Systems and Planning, is decentralisation a significant key to sustainable development? Technical Papers. The University of Melbourne, p20-34.

Evans, Alan W. (2004). Economics and Land Use Planning: Blackwell Publishing.

Fagerström, M. H. Hoang, I Messing, \& Z. M Wen. (2003). A participatory approach for intergrated conservation of planning in a small catchment in Loess plateau, China. Part I. Approach and methods. Antena 54, PP 255-269.

FAO. (1990). Participation in practice: Lessons from the FAO people's participation programme. Rome: Food and Agriculture Organization.

FAO. (1993). Guidelines for land-use planning. Food and Agriculture organization of United Nations. Rome, Italy: Food and Agriculture organization of United Nations.

FAO. (1995). Planning for sustainable use of land resources: Towards a new approach. Rome, Italy: Food and Agriculture Organization.

FAO. (2007). Land evaluation. Towards a revised framework. . Land and water discussion paper 6. 
FAO. (2011). Vietnam and FAO: Achievements and success stories: FAO Representation in Vietnam.

FAO, \& UNEP. (1999). The future of our land: Facing the challenge. Guidelines for integrated planning for sustainable management of land resources: Food and Agriculture Organization.

FAO/UNEP. (1997). Negotiating a Sustainable Future for Land. Structural and Institutional Guidelines for Land Resources Management in the 21st Century.: Food and Agriculture Organization/ United Nations Environment Programme.

Farber, stephen C, Robert Costanza, \& Matthew A Wilson. (2002). Economic and ecological concepts for valuing econsystem services. Ecological economics, 41, P375-392.

Fernandes, Nelson F., Renato F. Guimarães, Roberto A. T. Gomes, Bianca C. Vieira, David R. Montgomery, \& Harvey Greenberg. (2004). Topographic controls of landslides in Rio de Janeiro: field evidence and modeling. CATENA, 55(2), 163181.

Fraser, Rob. (2009). Land Heterogeneity, Agricultural Income Forgone and Environmental Benefit: An Assessment of Incentive Compatibility Problems in Environmental Stewardship Schemes. Journal of Agricultural Economics, 60(1), P190-201.

Golley, Frank .B, \& Juan Bellot. (1999). Rural planning from an environmental systems perpective. Springer series on envoronment management, p125, 242.

Gorsevski, Pece V., Paul E. Gessler, Jan Boll, William J. Elliot, \& Randy B. Foltz. (2006). Spatially and temporally distributed modeling of landslide susceptibility. Geomorphology, 80, P178-198.

GSO. (2010). National statistical data in 2010. National statistical office.

GSO Hoa Binh. (2010). Statistical data in 2010. Provincial statistical office of Hoa Binh.

GSO Mai Chau. (2010). Statistical data in 2010. District statistical office of Mai Chau.

GSO Maichau. (2001). Statistical data in 2001. District statistical office of Mai Chau. 
GSO Maichau. (2002). Statistical data in 2002. District statistical office of Mai Chau.

GSO Maichau. (2003). Statistical data in 2003. District statistical office of Mai Chau.

GSO Maichau. (2004). Statistical data in 2004. District statistical office of Mai Chau.

GSO Maichau. (2005). Statistical data in 2005. District statistical office of Mai Chau.

GSO Maichau. (2006). Statistical data in 2006. District statistical office of Mai Chau.

GSO Maichau. (2007). Statistical data in 2007. District statistical office of Mai Chau.

GSO Maichau. (2008). Statistical data in 2008. District statistical office of Mai Chau.

GSO Maichau. (2009). Statistical data in 2009. District statistical office of Mai Chau.

GSO Maichau. (2010). Statistical data in 2010. District statistical office of Mai Chau.

Guzzetti, Fausto. (2000). Landslide fatalities and the evaluation of landslide risk in Italy. Engineering Geology, 58, p89-107.

Guzzetti, Fausto. (2002). Landslide hazard assessment and risk evaluation: Limits and prospectives. Proceedings of the 4th EGS Plinius Conference held at Mallorca, Spain, October 2002.

Guzzetti, Fausto, Francesca Ardizzone, Mauro Cardinali, Mauro Rossi, \& Daniela Valigi. (2009). Landslide volumes and landslide mobilization rates in Umbria, central Italy. Earth and Planetary Science Letters, 279(3-4), 222-229.

Guzzetti, Fausto, Alberto Carrara, Mauro Cardinali, \& Paola Reichenbach. (1999). Landslide hazard evaluation: a review of current techniques and their application in a multi-scale study, Central Italy. Geomorphology, 31(1-4), 181-216.

Guzzetti, Fausto, Paola Reichenbach, Mauro Cardinali, Mirco Galli, \& Francesca Ardizzone. (2005). Probabilistic landslide hazard assessment at the basin scale. Geomorphology, 72(1-4), 272-299. 
Ha, Tran Viet. (2010). Growth and quality of indigenous bamboo species in the mountainous regions of Northern Vietnam. Georg-August-Universität Göttingen, Goettingen.

Hansjürgens, Bernd. (2004). Economic valuation through cost-benefit analysis possibilities and limitations. Toxicology, 205, p241-252.

Hessel, Rudi, Jolanda Van den Berg, Oumar Kabore, Arie Van Kekem, Simone Verzandvoort, Jean-Marie Dipama, et al. (2009). Linking participatory and GISbased land use planning methods: A case study from Burkina Faso. Land Use Policy 26, PP 1162-1172.

Hietel, Elke, Rainer Waldhardt, \& Annette Otte. (2005). Linking socio-economic factors, environment and land cover in the German Highlands, 1945-1999. Journal of Environmental Management, 75, P133-143.

Hofmanna, Ekkehard, \& Georg von Wangenheim. (2003). Trade secrets versus Cost Benefit Analysis. International Review of Law and Economics, 22, p511-526.

Huy, Man Quang. (2009). Building a Decision Support System for Agricultural Land Use Planning and Sustainable Management at the District Level in Vietnam. . GeorgAugust-Universität, Göttingen.

Huyen, Ton Gia. (1993). Country Profile: Land Use in Vietnam: Facts and Figures. $M C B$ University Press. Sustainable development. , 1(3), p4-7.

Jelier, A. J. Vervloet, Nijman Jan-Hein, \& J. Somsen Arjan. (2005). Planning for future; towards a sustainable design and land use of an ancient flooded military defence line. Landscape and Urban planning 70, P153-163.

Jocelyn, A. Songco. (2002). Do Rural Infrastructure Investments Benefit the Poor? Evaluating Linkages: A Global View, A Focus on Vietnam: School of International and Public Affairs, Columbia University and the World Bank, Vietnam.

Jurgens, Clifford .R. (1993). Strategic planning for sustainable rural development. Landscape and Urban planning 27, P253-258. 
Kelly, Stephanie B. (2004). Community planning. How to solve urban and environmental problems: Rowman \&Littlefield publishers.

Khanh, Nguyen Quoc. (2009). Landslide hazard assessment in Muonglay, Vietnam. Applying GIS and remote sensing. Ernst-Moritz-Arndt-University Greifswald.

Komac, Marko. (2006). A landslide susceptibility model using the Analytical Hierarchy Process method and multivariate statistics in perialpine Slovenia. Geomorphology, 74, 17-28.

Koomen, Eric, \& Judith Borsboom-van Beurden. (2011). Land - Use modelling in Planning Practics: Springer Publisher.

Laborte, A. G., R. P. Roetter, \& C. T. Hoanh. (2002). The land use planning and analysis system of the systems research network in Asia. Proceedings of the 2nd international conference on multiple objective decision support systems for land, water and environmental management, Australia.

Lee, Saro, Ueechan Chwae, \& Kyungduck Min. (2002). Landslide susceptibility mapping by correlation between topography and geological structure: the Janghung area, Korea. Geomorphology, 46, 149-162.

Lee, Saro, \& Nguyen Tu Dan. (2005). Probabilistic landslide susceptibility mapping in the Lai Chau province of Vietnam: focus on the relationship between tectonic fractures and landslides. Environ Geol, 48, 778-787.

Li, Zhong-Wu, Guang-Ming Zeng, Hua Zhang, Bin Yang, \& Sheng Jiao. (2007). The integrated eco-environment assessment of the red soil hilly region based on GIS--A case study in Changsha City, China. Ecological Modelling, 202(3-4), 540-546.

Liu, Yong, Xiaojian Lv, Xiaosheng Qin, Huaicheng Guo, Yajuan Yu, Jinfeng Wang, et al. (2007). An integrated GIS-based analysis system for land-use management of lake areas in urban fringe. Landscape and Urban planning, 82(4), 233-246.

Lloyd, Christopher D. (2010). Spatial data analysis: An introduction for GIS users: Oxford university press. 
Loi, Nguyen Van. (2008). Use of GIS modelling in assessment of forestry land's potential in Thua Thien Hue province of central Vietnam. Georg-August-Universität, Göttingen.

Long, Hualou, Guoping Tang, Xiubin Lia, \& Gerhard .K. Heilig. (2007). Socio-economic driving forces of land-use change in Kunshan, the Yangtze River Delta economic area of China. Environmental Management, 83, P351-364.

Long, Nguyen Thanh. (2008). Landslide susceptibility mapping of the mountainous area in A Luoi District, Thua Thien Hue Province, Vietnam Vrije Universiteit Brussel, Belgium.

Met Station. (2010). Meteorological data of Maichau district: Maichau Meteorological Station, Hoabinh Province.

Miller, William, Michael G. Collins, Frederick R. Steiner, \& Edward Cook. (1998). An approach for greenway suitability analysis. Landscape and Urban Planning 42, p91-105.

Mueller, Daniel. (2003). Land-use Change in the Central Highlands of Vietnam: A spatial econometric model combining satellite imagery and village survey data. GeorgAugust-University Goettingen.

Munda, Giuseppe. (1996). Cost-benefit analysis in integrated environmental assessment: Som methodological issues. Ecological economics, 19, p157- 168.

Nath, Shree S., John P. Bolte, Lindsay G. Ross, \& Jose Aguilar-Manjarrez. (2000). Applications of geographical information systems (GIS) for spatial decision support in aquaculture. Aquacultural Engineering, 23(1-3), 233-278.

Neuhäuser, Bettina , \& Birgit Terhorst. (2007). Landslide susceptibility assessment using "weights-of-evidence" applied to a study area at the Jurassic escarpment (SWGermany). Geomorphology, 86, 12-24.

Nidumolu, Uday Bhaskar, Cajm de Bie, Herman van Keulen, Andrew K. Skidmore, \& Karl Harmsen. (2006). Review of a land use planning programme through the soft systems methodology. Land Use Policy, 23(2), 187-203. 
Official dispatch. (1999). Guideline of Land use inventory in 2000: Vietnam General Department of Land Management.

Parise, Mario, \& Randall W. Jibson. (2000). A seismic landslide susceptibility rating of geologic units based on analysis of characteristics of landslides triggered by the 17 January, 1994 Northridge, California earthquake. Engineering Geology, 58, 251270.

Pasakarrnis, Giedrius, \& Vida Maliene. (2010). Towards sustainable rural development in central and eastern europe: Applying land consolidation. Land use Policy 27, P545549.

Pekka, Korhonen, \& Wallenius Jyrki. (2001). The Analytic Hierarchy Process in Natural resource and environmental decision making. Chapter 3. Kluwer Academic Publishers, P37.

Pradhan, Biswajeet, Shattri Mansor, Asro Lee, \& Manfred F. Buchroithner. (2008). Application of a data mining model for landslide hazard mapping. The international Archives of the Photogrammetry, Remote Sensing and Spartial Information Sciences, XXXVII (Part B8), p187-196.

Puginier, Oliver. (2002). Hill tribes struggling for a land deal: Participatory land use planning in northern Thailand amid controversial policies. Humboldt University, Berlin.

Quang, Nguyen. (2003). Review of Existing Planning System: Obstacles and Strategies Moving toward Innovative Planning Approaches. Case study of Ha Tinh Planning System: GTZ, PDP-HaTinh.

Quy, Doan Cong, Nguyen Thi Vong, Vu Thi Binh, Nguyen Quang Hoc, \& Do Thi Tam. (2005). Land Use Planning: Agricultural Publisher, Hanoi, Vietnam.

Richard, S. J. Tol. (1995). The Damage Costs Of Climate Change Toward More Comprehensive Calculations. Environmental and Resource Economics, 5, P353374. 
Roetter, R. P., C. T. Hoanh, A. G. Laborte, H. Van Keulen, M. K. Van Ittersum, C. Dreiser, et al. (2005). Integration of systems network (SysNet) tools foe regional land use scenario analysis in Asia. EnvironmentalModelling \& software 20, PP 291-307.

Saaty, T. L. (1977). A Scaling Method for Priorities in Hierarchical Structures. Journal of mathematical psychology, 25, 234-281.

Saaty, T. L. (1980). The Analytic Hierarchy Process. New York: McGraw-Hill.

Saaty, T. L. (1987). Risk-Its Priority and Probability: The Analytic Hierarchy Process. Risk Analvsis, 7(2), P159-172.

Saaty, T. L. (1990). How to make a decision: The Analytic Hierarchy Process. European Journal of Operational Research, 48, 9-26.

Saaty, T. L. (2008). Decision making with the analytic hierarchy process. Int. J. Services Sciences, 1(1), P83-98.

Saaty, T. L., \& M. Ozdemir. (2003). Negative Priorities in the Analytic Hierarchy Process. Mathematical and Computer Modelling, 38, P1063-1075.

Saaty, T. L., \& Luis .G. Vargas. (2001). Models, methods, concepts and applications of analytic hierarchy process. Kluver Academic Publishers.

Selman, Paul. (2009). Planning for landscape multifunctionality. Sustainability: Science, practice, \& Policy 5(2), P45-52.

SEMLA. (2009). Integrated Land Use Planning: Results and lessions learnt. Hanoi, Vietnam: Strengthening Environmental Management and Land Administration. Vietnam - Sweden Cooperation Programme.

Sidle, Roy C, \& Hirotaka Ochiai. (2006). Landslides: Processes, Prediction, and Land Use: American Geophysical Union, Washington DC, USA.

Silberstein, Jane, \& Chris Maser. (2003). Land use planning for sustainable development: Lewis Publisher. 
Simpson, David, \& James Walker. (1987). Extending cost-benefit analysis for energy investment choices. Energy policy, 15(3), p217-227.

Smith, Anne E. (2010). Climate Engineering Alternative Perspective. In B. Lomborg (Ed.), Smart solutions to climate change: Camparison Costs and Benefits (pp. p62-73): Cambrige University Press.

Son, N. T., T. V. Hieu, R. P. Shrestha, N. T. Trieu, N. V. Kien, V. T. Anh, et al. (2008). Integrated land-use planning for sustainable agriculture and natural resources management in Vietnamese Mekong delta. AEJ, 6, P307-324.

Store, Ron, \& Jukka Jokimäki. (2003). A GIS-based multi-scale approach to habitat suitability modeling. Ecological Modelling 169, p1-15.

Tan, Quang Nguyen. (2006). Forest devolution in Vietnam: Differentiation in benefits from forest among local households. Forest Policy and Economics, 8(4), P409-420.

The National Land Use Planning Commission. (1998). Guidelines for participatory village land management in Tanzania. Peramiho, Tanzania: Peramiho Printing Press.

Thieken, A. H., V. Ackermann, F. Elmer, H. Kreibich, B. Kuhlmann, U. Kunert, et al. (2008). Methods for the evaluation of direct and indirect flood losses: 4th International Symposium on Flood Defence: Managing Flood Risk, Reliability and Vulnerability. Toronto, Ontario, Canada

Thien, Tran Thi Minh. (2004). GIS and Remote Sensing based for quantitative prediction of Landside Hazard Zonation, case study Thua Thien Hue province of Vietnam. Universiteit Gent Vrije Universiteit Brussel Belgium.

Thomas, Rhodri. H., \& F. Brian Blakemore. (2007). Elements of a cost-benefit analysis for improving salmonid spawning habitat in the River wye. Journal of Environmental Management, 83, P471-480.

Thu, Dao Chau. (2009). Upland Utilization for Agricultural Development in Vietnam: Potentiality and Challenge. Hanoi, Vietnam: Agricultural Publisher. 
Trung, Nguyen Hieu. (2006). Comparing land use planning approaches in the Mekong delta, Vietnam. Wageningen University, Wageningen, Holland.

Trung, Nguyen Hieu, Le Quang Tri, M. E. F. Van Mensvoort, \& A. Bregt. (2004). GIS for participatory land use planning in the Mekong delta, Vietnam. The 4th international conference of Asian federation of information technology in agriculture and natural resources, Bangkok, Thailand.

UN. (1987). Towards Sustainable Development. In Our Common Future: United Nations.

UN. (2009). Case Studies on Community Participation: United Nations.

Van, Tran Tan, Le Viet Dung, Pham Hong Duc Phuoc, \& Le Van Du. (2006). Vetiver system for natural disaster mitigation and environmental protection in Vietnam An overview Hanoi Vietnam: Ministry of Natural Resources and Environment.

Varnes, David .J. (1984). Landslide hazard zonation: a review of principles and practice. Paris: The United Nations educational, scientific and cultural organization.

Vo, Dang Hung, \& Tran Nhu Trung. (2007). Land Administration for Poverty Reduction in Vietnam. "Good Land Administration - It's Role in the Economic Development", International Workshop, Ulaanbaatar, Mongolia. June 27-29, 2007.

Volkman, David A. (1997). A consistent yield-based capital budgeting method. Journal of financial and strategic decisions, 10(3), p75-87.

Wattage, Premachandra, \& Simon Mardle. (2008). Total economic value of wetland conservation in Sri Lanka identifying use and non-use values. Wetlands Ecol Manage, 16, P359-369.

WB. (2008). Vietnam-country overview: World Bank.

WCED. (1987). Our common future. Oxford University Press, World commision on Environment and development, London. Oxford University Press.

Weng, Qihao. (2010). Remote sensing and GIS integration: Theories, Methods, and Applications: McGraw Hill. 
Westen, C. J. van, T. W. J. van Asch, \& R. Soeters. (2006). Landslide hazard and risk zonation-why is it still so difficult? Bull Eng Geol Env, 65, 167-184.

William, D. Sunderlin. (2006). Poverty alleviation through community forestry in Cambodia, Laos, and Vietnam: An assessment of the potential. Forest Policy and Economics, 8(4), P386-396.

Yen, Bui Tan, Suan Pheng Kam, Pham Quang Ha, Chu Thai Hoanh, Bui Huy Hien, Jean-Christophe Castella, et al. (2002). Exploring land use options for agricultural development in Bac Kan province, Vietnam. Paper symposium 30, 17th World Congress of Soil Science.

Zinck, J. Alfred, Jaime López, Graciela I. Metternicht, Dhruba P. Shrestha, \& Lorenzo Vázquez-Selem. (2001). Mapping and modelling mass movements and gullies in mountainous areas using remote sensing and GIS techniques. International Journal of Applied Earth Observation and Geoinformation, 3(1), 43-53. 


\section{APPENDICES}

Appendix 1 Prediction of landslide susceptibility in Maichau District

\begin{tabular}{|c|c|c|c|}
\hline \multirow{2}{*}{ Commune } & \multicolumn{3}{|c|}{ Category of landslide susceptibility (ha) } \\
\hline & Low & Moderate & High \\
\hline Cun Pheo & 178.16 & $4,260.58$ & $1,686.02$ \\
\hline Van Mai & 49.92 & $1,960.25$ & $1,578.58$ \\
\hline Ba Khan & 234.08 & $1,571.02$ & 161.66 \\
\hline Thung Khe & 100.85 & $1,474.58$ & 261.34 \\
\hline Na Phon & 16.11 & 291.59 & 178.21 \\
\hline Phuc San & 141.12 & $2,005.29$ & 717.98 \\
\hline Bao La & 70.82 & $1,642.81$ & 545.34 \\
\hline Pieng Ve & 2.04 & $1,024.80$ & 511.91 \\
\hline Mai Hich & 2.83 & $2,307.05$ & $1,710.94$ \\
\hline Pu Pin & 19.27 & $1,238.85$ & 878.99 \\
\hline Tong Dau & 62.60 & $1,153.40$ & 802.89 \\
\hline Tan Mai & 22.13 & $1,594.31$ & $1,200.20$ \\
\hline Sam Khoe & 5.29 & $1,691.53$ & 827.39 \\
\hline Mai Chau & 28.69 & 707.89 & 379.99 \\
\hline Dong Bang & 189.89 & $1,874.30$ & 679.77 \\
\hline Hang Kia & 101.88 & $1,347.90$ & 825.58 \\
\hline $\mathrm{Na} \mathrm{Mo}$ & 98.79 & $1,700.70$ & 938.17 \\
\hline Nong Luong & 8.82 & $1,098.78$ & 532.04 \\
\hline $\mathrm{PaCo}$ & 122.90 & $1,490.07$ & 314.82 \\
\hline Chieng Chau & 0.23 & 497.59 & $1,171.60$ \\
\hline Tan Son & 178.65 & 935.48 & 43.53 \\
\hline Mai Ha & 7.91 & $1,078.41$ & 742.26 \\
\hline Tan Dan & 0.00 & $1,361.03$ & $2,288.27$ \\
\hline Total & $1,642.98$ & $34,308.21$ & $18,977.48$ \\
\hline
\end{tabular}

Source: Own calculation 
Appendix 2 Category of integrated map in Maichau District

\begin{tabular}{|c|c|c|c|}
\hline \multirow{2}{*}{ Commune } & \multicolumn{3}{|c|}{ Category of suitability (ha) } \\
\hline & High & Moderate & Low \\
\hline TT Mai Chau & 28.69 & $1,027.64$ & 60.24 \\
\hline Ba Khan & 234.08 & $1,721.86$ & 10.82 \\
\hline Bao La & 70.82 & $2,067.90$ & 120.25 \\
\hline Chieng Chau & 0.23 & $1,286.53$ & 382.66 \\
\hline Cun Pheo & 178.16 & $5,253.64$ & 692.96 \\
\hline Dong Bang & 189.89 & $2,501.90$ & 52.17 \\
\hline Hang Kia & 101.88 & $2,133.82$ & 39.66 \\
\hline Mai Ha & 7.91 & $1,639.44$ & 181.22 \\
\hline Mai Hich & 2.83 & $3,666.73$ & 351.26 \\
\hline $\mathrm{Na} \mathrm{Meo}$ & 98.79 & $2,525.24$ & 113.64 \\
\hline Na Phon & 16.11 & 334.74 & 135.07 \\
\hline Nong Luong & 8.82 & $1,517.44$ & 113.40 \\
\hline $\mathrm{PaCo}$ & 122.90 & $1,671.88$ & 133.01 \\
\hline Phuc San & 141.12 & $2,647.57$ & 75.68 \\
\hline Pieng Ve & 2.04 & $1,364.79$ & 171.91 \\
\hline $\mathrm{Pu}$ Bin & 19.27 & $1,957.95$ & 159.90 \\
\hline Sam Khoe & 5.29 & $2,423.48$ & 95.43 \\
\hline Tan Dan & 0.00 & $3,455.83$ & 193.47 \\
\hline Tan Mai & 22.13 & $2,677.28$ & 117.24 \\
\hline Tan Son & 178.65 & 968.41 & 10.59 \\
\hline Thung Khe & 100.85 & $1,710.67$ & 25.26 \\
\hline Tong Dau & 62.60 & $1,820.30$ & 135.98 \\
\hline Van Mai & 49.92 & $3,454.22$ & 84.61 \\
\hline Total & $1,642.97$ & $49,829.27$ & $3,456.43$ \\
\hline
\end{tabular}

Source: Own calculation 
Appendix 3 List of actual landslides from 2000-2010 in Maichau District

\begin{tabular}{|c|c|c|c|c|c|}
\hline $\begin{array}{c}\text { ID } \\
\text { (landslide) }\end{array}$ & Place (where) & $\begin{array}{c}\text { Year } \\
\text { (when) }\end{array}$ & $\begin{array}{c}\text { Deaths } \\
\text { (person) }\end{array}$ & $\begin{array}{c}\text { Affected } \\
\text { Area }(\mathrm{m} 2)\end{array}$ & Land use \\
\hline 1 & $\mathrm{~Pa}$ Co 1 & 2007 & & 5,000 & Bamboo \\
\hline 2 & Pa Co 2 & 2007 & 1 & 400 & Resident \\
\hline 3 & Xa Linh & 2007 & & 308 & Resident \\
\hline 4 & Hang Kia & 2007 & & 3,300 & Bamboo, resident \\
\hline 5 & Thung Mon & 2007 & & 4,000 & Maize \\
\hline 6 & Tam Hoa & 2000 & & 5,000 & Bamboo \\
\hline 7 & Bo Liem & 2007 & & 300 & Resident \\
\hline 8 & Dong Bang & 2007 & & 5,000 & Bamboo \\
\hline 9 & Bo Bau & 2007 & & 3,000 & Maize \\
\hline 10 & Khu 81 & 2007 & & 11,050 & Bamboo, road \\
\hline 11 & Dan den & 2006 & & 4,000 & Maize \\
\hline 12 & Xom Panh & 2002 & & 2,000 & Bamboo \\
\hline 13 & Pheo 1 & 2007 & & 2,700 & Maize \\
\hline 14 & Pheo 2 & 2007 & & 31,500 & Maize, bamboo, road \\
\hline 15 & Pheo 4 & 2007 & & 10,000 & Maize \\
\hline 16 & Muot & 2008 & & 50,000 & Maize \\
\hline 17 & Pheo 3 & 2007 & & 4,000 & Rice \\
\hline 18 & Xom Vanh & 2007 & & 803 & Rice \\
\hline 19 & Xom Panh & 2005 & & 4,000 & Rice \\
\hline 20 & Xom Pung & 2007 & & 2,100 & Resident \\
\hline 21 & Xom Pung & 2007 & & 48,000 & Rice \\
\hline 22 & Xom Ve & 2007 & & 5,000 & Rice \\
\hline 23 & Xom Bao & 2007 & & 24,900 & Rice, resident, road \\
\hline 24 & Xom Van & 2006 & 1 & 1,000 & Rice \\
\hline 25 & Co Nghia & 2005 & & 2,000 & Maize \\
\hline 26 & Xom Cum & 2007 & & 7,000 & Cassava \\
\hline 27 & Xom Bang & 2007 & & 6,000 & Cassava \\
\hline 28 & Xom Buoc & 2000 & & 30,000 & Rice, cassava \\
\hline 29 & Pu Ngheo & 2005 & & 5,000 & Maize \\
\hline 30 & Xom Muon & 2001 & & 5,000 & Rice \\
\hline 31 & Tan Tien & 2002 & & 5,000 & Rice \\
\hline 32 & Xom Nam & 2005 & & 2,000 & Rice \\
\hline 33 & Xom Dem & 2005 & & 10,000 & Bamboo \\
\hline 34 & Dong Son & 2002 & & 10,000 & Maize \\
\hline 35 & Chieng & 2003 & & 10,000 & Acacia SP \\
\hline 36 & Tham Hau & 2007 & & 22,000 & Rice, bamboo, maize \\
\hline 37 & Xom Ban & 2007 & 1 & 8,000 & Bamboo \\
\hline 38 & Bai Khai & 2007 & & 5,500 & Bamboo, road \\
\hline 39 & Bai Ca & 2009 & & 3,000 & Bamboo \\
\hline 40 & Da Do & 2007 & & 7,000 & Acacia SP \\
\hline
\end{tabular}




\begin{tabular}{|c|c|c|}
\hline 41 & Mai Lang & 2007 \\
\hline 42 & Xom Lanh & 2007 \\
\hline 43 & Xom Cai & 2007 \\
\hline 44 & Diềm 2 & 2007 \\
\hline 45 & Xom Nhan & 2007 \\
\hline 46 & Soi Doi & 2000 \\
\hline 47 & Xom Doi & 2007 \\
\hline 48 & Xom Not & 2007 \\
\hline 49 & Xom Not & 2004 \\
\hline 50 & Xom Not & 2007 \\
\hline 51 & Xom Xop & 2007 \\
\hline 52 & Xom Phuc & 2007 \\
\hline 53 & Xom San & 2007 \\
\hline 54 & So Lo & 2007 \\
\hline 55 & Suoi Nhung & 2007 \\
\hline 56 & Suoi Lam & 2007 \\
\hline 57 & Mo Rut & 2007 \\
\hline 58 & $\mathrm{Go} \mathrm{Mu}$ & 2007 \\
\hline 59 & Go Mao & 2007 \\
\hline 60 & Go Mao & 2007 \\
\hline 61 & Xom Bang & 2007 \\
\hline 62 & Xom Bang & 2007 \\
\hline 63 & Khan Ha & 2006 \\
\hline 64 & An Thuong & 2007 \\
\hline 65 & Khan Thuong & 2007 \\
\hline 66 & Na Quan & 2007 \\
\hline 67 & Xom Vat & 2007 \\
\hline 68 & Xom Vat 2 & 2007 \\
\hline 69 & Phieng Xa & 2007 \\
\hline 70 & Bo Bau 2 & 2003 \\
\hline 71 & Suoi 10 & 2006 \\
\hline 72 & $\mathrm{Na} \mathrm{Va}$ & 2008 \\
\hline 73 & $\mathrm{Pu} \mathrm{Lau}$ & 2007 \\
\hline 74 & Xom Dau & 2007 \\
\hline 75 & Tong Dau & 2007 \\
\hline 76 & Xom Tong & 2007 \\
\hline 77 & Tong Dau & 2006 \\
\hline 78 & Mai Chau & 2007 \\
\hline 79 & Cha Ha & 2007 \\
\hline 80 & $\mathrm{Pu}$ Tooc & 2007 \\
\hline 81 & $\mathrm{Na}$ Kem & 2003 \\
\hline 82 & $\mathrm{Na} \mathrm{Meo}$ & 2002 \\
\hline 83 & $\mathrm{Na} \mathrm{Mo}$ & 2007 \\
\hline 84 & Na Mo 2 & 2007 \\
\hline 85 & Xom Te & 2009 \\
\hline 86 & Xom Pung & 2008 \\
\hline 87 & Xom Khoe & 2007 \\
\hline
\end{tabular}

\begin{tabular}{|c|c|}
\hline 5,000 & Maize \\
\hline 80,000 & Maize, Bamboo \\
\hline 5,000 & Bamboo \\
\hline 10,000 & Bamboo \\
\hline 55,000 & Maize \\
\hline 2,000 & Bamboo \\
\hline 13,000 & Bamboo \\
\hline 20,000 & Bamboo \\
\hline 20,000 & Maize \\
\hline 10,000 & Bamboo \\
\hline 18,000 & Bamboo \\
\hline 30,000 & Bamboo \\
\hline 15,000 & Bamboo \\
\hline 30,000 & Bamboo \\
\hline 25,000 & Bamboo \\
\hline 1,000 & Resident \\
\hline 20,000 & Maize \\
\hline 3,400 & Maize, resident \\
\hline 15,000 & Rice, bamboo \\
\hline 51,200 & Bamboo, road \\
\hline 1,700 & Bamboo, resident \\
\hline 1,000 & Maize \\
\hline 1,000 & Acacia SP \\
\hline 400 & Resident \\
\hline 300 & Road \\
\hline 1,200 & Resident \\
\hline 1,900 & Bamboo, resident \\
\hline 1,120 & Bamboo, resident \\
\hline 17,400 & Bamboo, resident, road \\
\hline 5,000 & Maize \\
\hline 2,000 & Bamboo \\
\hline 2,000 & Bamboo \\
\hline 10,000 & Maize \\
\hline 30,000 & Cassava, bamboo \\
\hline 1,500 & Maize \\
\hline 1,200 & Resident \\
\hline 5,000 & Bamboo \\
\hline 5,000 & Bamboo \\
\hline 1,000 & Cassava \\
\hline 1,000 & Acacia SP \\
\hline 35,000 & Rice, maize \\
\hline 5,000 & Maize \\
\hline 11,050 & Bamboo, road \\
\hline 1,000 & Bamboo \\
\hline 2,000 & Bamboo \\
\hline 3,000 & Bamboo \\
\hline 3,000 & Maize \\
\hline
\end{tabular}




\begin{tabular}{|c|c|c|c|c|c|}
\hline 88 & Xom Kha & 2005 & & 5,000 & Bamboo \\
\hline 89 & Chieng Chau & 2003 & & 10,000 & Cassava \\
\hline 90 & Xom Mo & 2000 & & 3,000 & Maize \\
\hline 91 & Xom Mo & 2001 & 1 & 5,000 & Maize \\
\hline 92 & Na Sai & 2009 & & 10,000 & Bamboo \\
\hline 93 & Na So & 2006 & & 5,000 & Maize \\
\hline 94 & Ban Lau & 2000 & & 2,000 & Maize \\
\hline 95 & Thung Khe & 2005 & & 5,000 & Bamboo \\
\hline 96 & Thung Coc & 2008 & & 3,000 & Maize \\
\hline 97 & Thung Uoi & 2002 & & 3,250 & Bamboo, road \\
\hline 98 & Thung Coc & 2007 & & 500 & Bamboo \\
\hline 99 & Pom Hay & 2006 & & 1,500 & Bamboo \\
\hline 100 & Thung Uoi & 2007 & & 5,000 & Maize \\
\hline 101 & Cha Day & 2002 & & 1,400 & Bamboo, resident \\
\hline 102 & Cha Day & 2001 & & 3,000 & Maize, bamboo \\
\hline 103 & Noong $\mathrm{O}$ & 2007 & & 5,000 & Maize, bamboo \\
\hline 104 & Cha Day & 2006 & & 1,800 & Bamboo, resident \\
\hline 105 & Nương nong Sau & 2007 & & 600 & Maize \\
\hline 106 & Hồ Nà Phặt & 2007 & & 5,000 & Maize \\
\hline 107 & Mai Hich & 2009 & & 5,000 & Bamboo \\
\hline 108 & Pu Puong & 2007 & & 10,000 & Maize, bamboo \\
\hline 109 & Suoi Buoc & 2006 & & 15,000 & Bamboo \\
\hline 110 & Suoi Xia & 2000 & & 12,000 & Rice \\
\hline 111 & Xom Cum & 2007 & & 5,000 & Maize \\
\hline 112 & $\mathrm{Na} \mathrm{Hi}$ & 2007 & & 3,000 & Bamboo \\
\hline 113 & Xom Nghe & 2009 & & 20,350 & Bamboo, road \\
\hline 114 & Xom Khan & 2002 & & 7,000 & Cassava \\
\hline 115 & Dac San & 2000 & & 3,000 & Maize \\
\hline 116 & Thanh Mai & 2005 & & 4,200 & Bamboo, resident \\
\hline 117 & Pù Thắm & 2003 & & 500 & Maize \\
\hline 118 & Nà Phặt & 2002 & & 2,000 & Bamboo \\
\hline 119 & Pom Hươm Noi & 2007 & & 15,800 & Maize, bamboo, resident \\
\hline 120 & Cha Day & 2007 & & 15,000 & Rice, bamboo \\
\hline 121 & Noong O & 2003 & & 4,500 & Rice, maize \\
\hline 122 & Boam Khoai & 2006 & & 400 & Maize \\
\hline 122 & & & 6 & $1,141,031$ & \\
\hline
\end{tabular}

Source: Own investigation 
Appendix 4 Costs and revenue of Acacia forest in Maichau District (Unit: VND 1000)

For year $^{+1}$ Acacia

\begin{tabular}{lcrrrrr}
\hline \multicolumn{1}{c}{ Lifetime } & $\begin{array}{c}\text { Costs } \\
\text { (nominal) }\end{array}$ & $\begin{array}{c}\text { Revenue } \\
\text { (nominal) }\end{array}$ & $\begin{array}{c}\text { Net } \\
\text { income } \\
\text { (nominal) }\end{array}$ & $\begin{array}{c}\text { Present } \\
\text { cash flow } \\
\text { (Costs) } \\
\text { (nominal) }\end{array}$ & $\begin{array}{r}\text { Present } \\
\text { cash flow } \\
\text { (Revenue) } \\
\text { (Nominal) }\end{array}$ & $\begin{array}{c}\text { Present } \\
\text { cash flow } \\
\text { (Net } \\
\text { income) } \\
\text { (Nominal) }\end{array}$ \\
\hline Year $^{+1}$ & 9562.50 & 0.00 & -9562.50 & 9562.50 & 0.00 & -9562.50 \\
Year $^{+2}$ & 2632.50 & 0.00 & -2632.50 & 2415.14 & 0.00 & -2415.14 \\
Year $^{+3}$ & 1375.00 & 0.00 & -1375.00 & 1157.31 & 0.00 & -1157.31 \\
Year $^{+4}$ & 1375.00 & 0.00 & -1375.00 & 1061.75 & 0.00 & -1061.75 \\
Year $^{+5}$ & 1375.00 & 0.00 & -1375.00 & 974.08 & 0.00 & -974.08 \\
Year $^{+6}$ & 1375.00 & 0.00 & -1375.00 & 893.66 & 0.00 & -893.66 \\
Year $^{+7}$ & 1475.00 & 79125.00 & 77650.00 & 879.49 & 47179.65 & 46300.16 \\
\hline Total & 19170.00 & 79125.00 & 59955.00 & 16943.93 & 47179.65 & 30235.72 \\
\hline Total in year & & & & & & \\
(accumulated) & 9562.50 & 0.00 & & 9562.50 & 0.00 & \\
Income/year & & & & & & 4319.39 \\
\hline
\end{tabular}

For year $^{+2}$ Acacia

\begin{tabular}{lrrrrrr}
\hline Lifetime & $\begin{array}{c}\text { Costs } \\
\text { (nominal) }\end{array}$ & $\begin{array}{c}\text { Revenue } \\
\text { (nominal) }\end{array}$ & $\begin{array}{c}\text { Net } \\
\text { income } \\
\text { (nominal) }\end{array}$ & $\begin{array}{c}\text { Present } \\
\text { cash flow } \\
\text { (Costs) } \\
\text { (nominal) }\end{array}$ & $\begin{array}{r}\text { Present } \\
\text { cash flow } \\
\text { (Revenue) } \\
\text { (Nominal) }\end{array}$ & $\begin{array}{c}\text { Present cash } \\
\text { flow (Net } \\
\text { income) } \\
\text { (Nominal) }\end{array}$ \\
\hline Year $^{+1}$ & 9562.50 & 0.00 & -9562.50 & 10423.13 & 0.00 & -10423.13 \\
Year $^{+2}$ & 2632.50 & 0.00 & -2632.50 & 2632.50 & 0.00 & -2632.50 \\
Year $^{+3}$ & 1375.00 & 0.00 & -1375.00 & 1261.47 & 0.00 & -1261.47 \\
Year $^{+4}$ & 1375.00 & 0.00 & -1375.00 & 1157.31 & 0.00 & -1157.31 \\
Year $^{+5}$ & 1375.00 & 0.00 & -1375.00 & 1061.75 & 0.00 & -1061.75 \\
Year $^{+6}$ & 1375.00 & 0.00 & -1375.00 & 974.08 & 0.00 & -974.08 \\
Year $^{+7}$ & 1475.00 & 79125.00 & 77650.00 & 958.65 & 51425.82 & 50467.17 \\
\hline Total & 19170.00 & 79125.00 & 59955.00 & 18468.89 & 51425.82 & 32956.93 \\
\hline $\begin{array}{l}\text { Total in year } \\
\text { (accumulated) }\end{array}$ & 12195.00 & 0.00 & & 13055.63 & 0.00 & \\
Income/year $^{+2}$ & & & & & & \\
\hline
\end{tabular}


For year $^{+3}$ Acacia

\begin{tabular}{|c|c|c|c|c|c|c|}
\hline Lifetime & $\begin{array}{c}\text { Costs } \\
\text { (nominal) }\end{array}$ & $\begin{array}{l}\text { Revenue } \\
\text { (nominal) }\end{array}$ & $\begin{array}{c}\text { Net } \\
\text { income } \\
\text { (nominal) }\end{array}$ & $\begin{array}{l}\text { Present } \\
\text { cash flow } \\
\text { (Costs) } \\
\text { (nominal) }\end{array}$ & $\begin{array}{c}\text { Present } \\
\text { cash flow } \\
\text { (Revenue) } \\
\text { (Nominal) }\end{array}$ & $\begin{array}{l}\text { Present cash } \\
\text { flow (Net } \\
\text { income) } \\
\text { (Nominal) }\end{array}$ \\
\hline Year $^{+1}$ & 9562.50 & 0.00 & -9562.50 & 11361.21 & 0.00 & -11361.21 \\
\hline Year $^{+2}$ & 2632.50 & 0.00 & -2632.50 & 2869.43 & 0.00 & -2869.43 \\
\hline Year $^{+3}$ & 1375.00 & 0.00 & -1375.00 & 1375.00 & 0.00 & -1375.00 \\
\hline Year $^{+4}$ & 1375.00 & 0.00 & -1375.00 & 1261.47 & 0.00 & -1261.47 \\
\hline Year $^{+5}$ & 1375.00 & 0.00 & -1375.00 & 1157.31 & 0.00 & -1157.31 \\
\hline Year $^{+6}$ & 1375.00 & 0.00 & -1375.00 & 1061.75 & 0.00 & -1061.75 \\
\hline Year $^{+7}$ & 1475.00 & 79125.00 & 77650.00 & 1044.93 & 56054.14 & 55009.22 \\
\hline Total & 19170.00 & 79125.00 & 59955.00 & 20131.09 & 56054.14 & 35923.06 \\
\hline $\begin{array}{l}\text { Total in year } \\
\text { (accumulated) }\end{array}$ & 13570.00 & 0.00 & & 15605.63 & 0.00 & \\
\hline Income/year & & & & & & 5131.87 \\
\hline
\end{tabular}

For year ${ }^{+4}$ Acacia SP

\begin{tabular}{|c|c|c|c|c|c|c|}
\hline Lifetime & $\begin{array}{c}\text { Costs } \\
\text { (nominal) }\end{array}$ & $\begin{array}{l}\text { Revenue } \\
\text { (nominal) }\end{array}$ & $\begin{array}{c}\text { Net } \\
\text { income } \\
\text { (nominal) }\end{array}$ & $\begin{array}{c}\text { Present } \\
\text { cash flow } \\
\text { (Costs) } \\
\text { (nominal) }\end{array}$ & $\begin{array}{c}\text { Present } \\
\text { cash flow } \\
\text { (Revenue) } \\
\text { (Nominal) }\end{array}$ & $\begin{array}{c}\text { Present cash } \\
\text { flow (Net } \\
\text { income) } \\
\text { (Nominal) }\end{array}$ \\
\hline Year $^{+1}$ & 9562.50 & 0.00 & -9562.50 & 12383.71 & 0.00 & -12383.71 \\
\hline Year $^{+2}$ & 2632.50 & 0.00 & -2632.50 & 3127.67 & 0.00 & -3127.67 \\
\hline Year $^{+3}$ & 1375.00 & 0.00 & -1375.00 & 1498.75 & 0.00 & -1498.75 \\
\hline Year $^{+4}$ & 1375.00 & 0.00 & -1375.00 & 1375.00 & 0.00 & -1375.00 \\
\hline Year $^{+5}$ & 1375.00 & 0.00 & -1375.00 & 1261.47 & 0.00 & -1261.47 \\
\hline Year $^{+6}$ & 1375.00 & 0.00 & -1375.00 & 1157.31 & 0.00 & -1157.31 \\
\hline Year $^{+7}$ & 1475.00 & 79125.00 & 77650.00 & 1138.97 & 61099.02 & 59960.05 \\
\hline Total & 19170.00 & 79125.00 & 59955.00 & 21942.89 & 61099.02 & 39156.13 \\
\hline $\begin{array}{l}\text { Total in year }{ }^{+4} \\
\text { (accumulated) }\end{array}$ & 14945.00 & 0.00 & & 18385.14 & 0.00 & \\
\hline Income/year & & & & & & 5593.73 \\
\hline
\end{tabular}


For year ${ }^{+5}$ Acacia

\begin{tabular}{|c|c|c|c|c|c|c|}
\hline Lifetime & $\begin{array}{c}\text { Costs } \\
\text { (nominal) }\end{array}$ & $\begin{array}{l}\text { Revenue } \\
\text { (nominal) }\end{array}$ & $\begin{array}{c}\text { Net } \\
\text { income } \\
\text { (nominal) }\end{array}$ & $\begin{array}{c}\text { Present } \\
\text { cash flow } \\
\text { (Costs) } \\
\text { (nominal) }\end{array}$ & $\begin{array}{c}\text { Present } \\
\text { cash flow } \\
\text { (Revenue) } \\
\text { (Nominal) }\end{array}$ & $\begin{array}{c}\text { Present cash } \\
\text { flow (Net } \\
\text { income) } \\
\text { (Nominal) }\end{array}$ \\
\hline Year $^{+1}$ & 9562.50 & 0.00 & -9562.50 & 13498.25 & 0.00 & -13498.25 \\
\hline Year $^{+2}$ & 2632.50 & 0.00 & -2632.50 & 3409.16 & 0.00 & -3409.16 \\
\hline Year $^{+3}$ & 1375.00 & 0.00 & -1375.00 & 1633.64 & 0.00 & -1633.64 \\
\hline Year $^{+4}$ & 1375.00 & 0.00 & -1375.00 & 1498.75 & 0.00 & -1498.75 \\
\hline Year $^{+5}$ & 1375.00 & 0.00 & -1375.00 & 1375.00 & 0.00 & -1375.00 \\
\hline Year $^{+6}$ & 1375.00 & 0.00 & -1375.00 & 1261.47 & 0.00 & -1261.47 \\
\hline Year $^{+7}$ & 1475.00 & 79125.00 & 77650.00 & 1241.48 & 66597.93 & 65356.45 \\
\hline Total & 19170.00 & 79125.00 & 59955.00 & 23917.75 & 66597.93 & 42680.18 \\
\hline $\begin{array}{l}\text { Total in year }^{+5} \\
\text { (accumulated) }\end{array}$ & 16320.00 & 0.00 & & 21414.80 & 0.00 & \\
\hline Income/year & & & & & & 6097.17 \\
\hline
\end{tabular}

For year $^{+6}$ Acacia

\begin{tabular}{lcrrrrr}
\hline \multicolumn{1}{c}{ Lifetime } & $\begin{array}{c}\text { Costs } \\
\text { (nominal) }\end{array}$ & $\begin{array}{c}\text { Revenue } \\
\text { (nominal) }\end{array}$ & $\begin{array}{c}\text { Net } \\
\text { income } \\
\text { (nominal) }\end{array}$ & $\begin{array}{c}\text { Present } \\
\text { cash flow } \\
\text { (Costs) } \\
\text { (nominal) }\end{array}$ & $\begin{array}{c}\text { Present } \\
\text { cash flow } \\
\text { (Revenue) } \\
\text { (Nominal) }\end{array}$ & $\begin{array}{c}\text { Present cash } \\
\text { flow (Net } \\
\text { income) } \\
\text { (Nominal) }\end{array}$ \\
\hline Year $^{+1}$ & 9562.50 & 0.00 & -9562.50 & 14713.09 & 0.00 & -14713.09 \\
Year $^{+2}$ & 2632.50 & 0.00 & -2632.50 & 3715.99 & 0.00 & -3715.99 \\
Year $^{+3}$ & 1375.00 & 0.00 & -1375.00 & 1780.66 & 0.00 & -1780.66 \\
Year $^{+4}$ & 1375.00 & 0.00 & -1375.00 & 1633.64 & 0.00 & -1633.64 \\
Year $^{+5}$ & 1375.00 & 0.00 & -1375.00 & 1498.75 & 0.00 & -1498.75 \\
Year $^{+6}$ & 1375.00 & 0.00 & -1375.00 & 1375.00 & 0.00 & -1375.00 \\
Year $^{+7}$ & 1475.00 & 79125.00 & 77650.00 & 1353.21 & 72591.74 & 71238.53 \\
\hline Total $^{\text {Total in year }}$ & 19170.00 & 79125.00 & 59955.00 & 26070.34 & 72591.74 & 46521.40 \\
\hline $\begin{array}{l}\text { (accumulated) } \\
\text { Income/year }\end{array}$ & 17695.00 & 0.00 & & 24717.13 & 0.00 & \\
\hline
\end{tabular}


For year $^{+7}$ Acacia

\begin{tabular}{|c|c|c|c|c|c|c|}
\hline Lifetime & $\begin{array}{c}\text { Costs } \\
\text { (nominal) }\end{array}$ & $\begin{array}{l}\text { Revenue } \\
\text { (nominal) }\end{array}$ & $\begin{array}{c}\text { Net } \\
\text { income } \\
\text { (nominal) }\end{array}$ & $\begin{array}{l}\text { Present } \\
\text { cash flow } \\
\text { (Costs) } \\
\text { (nominal) }\end{array}$ & $\begin{array}{c}\text { Present } \\
\text { cash flow } \\
\text { (Revenue) } \\
\text { (Nominal) }\end{array}$ & $\begin{array}{c}\text { Present cash } \\
\text { flow (Net } \\
\text { income) } \\
\text { (Nominal) }\end{array}$ \\
\hline Year $^{+1}$ & 9562.50 & 0.00 & -9562.50 & 16037.27 & 0.00 & -16037.27 \\
\hline Year $^{+2}$ & 2632.50 & 0.00 & -2632.50 & 4050.43 & 0.00 & -4050.43 \\
\hline Year $^{+3}$ & 1375.00 & 0.00 & -1375.00 & 1940.92 & 0.00 & -1940.92 \\
\hline Year $^{+4}$ & 1375.00 & 0.00 & -1375.00 & 1780.66 & 0.00 & -1780.66 \\
\hline Year $^{+5}$ & 1375.00 & 0.00 & -1375.00 & 1633.64 & 0.00 & -1633.64 \\
\hline Year $^{+6}$ & 1375.00 & 0.00 & -1375.00 & 1498.75 & 0.00 & -1498.75 \\
\hline Year $^{+7}$ & 1475.00 & 79125.00 & 77650.00 & 1475.00 & 79125.00 & 77650.00 \\
\hline Total & 19170.00 & 79125.00 & 59955.00 & 28416.67 & 79125.00 & 50708.33 \\
\hline $\begin{array}{l}\text { Total in year }{ }^{+7} \\
\text { (accumulated) }\end{array}$ & 19170.00 & 0.00 & & 28416.67 & 0.00 & \\
\hline Income/year & & & & & & 7244.05 \\
\hline
\end{tabular}


Appendix 5 Costs and revenue of Bamboo forest in Maichau District (Unit: VND 1000)

For year ${ }^{+1}$ Bamboo

\begin{tabular}{|c|c|c|c|c|c|c|}
\hline Lifetime & $\begin{array}{c}\text { Costs } \\
\text { (nominal) }\end{array}$ & $\begin{array}{l}\text { Revenue } \\
\text { (nominal) }\end{array}$ & $\begin{array}{c}\text { Net } \\
\text { income } \\
\text { (nominal) }\end{array}$ & $\begin{array}{c}\text { Present } \\
\text { cash flow } \\
\text { (Costs) } \\
\text { (nominal) }\end{array}$ & $\begin{array}{l}\text { Present } \\
\text { cash flow } \\
\text { (Revenue) } \\
\text { (Nominal) }\end{array}$ & $\begin{array}{c}\text { Present cash } \\
\text { flow (Net } \\
\text { income) } \\
\text { (Nominal) }\end{array}$ \\
\hline Year $^{+1}$ & 6476.68 & 0.00 & -6476.68 & 6476.68 & 0.00 & -6476.68 \\
\hline Year $^{+2}$ & 2148.23 & 0.00 & -2148.23 & 1970.85 & 0.00 & -1970.85 \\
\hline Year $^{+3}$ & 2102.69 & 0.00 & -2102.69 & 1769.79 & 0.00 & -1769.79 \\
\hline Year $^{+4}$ & 1782.03 & 0.00 & -1782.03 & 1376.05 & 0.00 & -1376.05 \\
\hline Year $^{+5}$ & 1782.03 & 5573.33 & 3791.30 & 1262.43 & 3948.29 & 2685.85 \\
\hline Year $^{+6}$ & 1782.03 & 8253.33 & 6471.30 & 1158.20 & 5364.10 & 4205.90 \\
\hline Year $^{+7}$ & 1782.03 & 13733.33 & 11951.30 & 1062.57 & 8188.74 & 7126.17 \\
\hline Year $^{+8}$ & 1782.03 & 17946.67 & 16164.64 & 974.83 & 9817.44 & 8842.61 \\
\hline Year $^{+9}$ & 1782.03 & 18346.67 & 16564.64 & 894.34 & 9207.57 & 8313.23 \\
\hline Year $^{+10}$ & 1782.03 & 18346.67 & 16564.64 & 820.50 & 8447.31 & 7626.82 \\
\hline Year $^{+11}$ & 1835.67 & 19946.67 & 18111.00 & 775.41 & 8425.69 & 7650.28 \\
\hline Year $^{+12}$ & 1835.67 & 19146.67 & 17311.00 & 711.38 & 7419.96 & 6708.58 \\
\hline Year $^{+13}$ & 1902.67 & 19146.67 & 17244.00 & 676.47 & 6807.30 & 6130.84 \\
\hline Year $^{+14}$ & 1966.65 & 15220.00 & 13253.35 & 641.48 & 4964.44 & 4322.96 \\
\hline Total & 30742.47 & 155660.00 & 124917.53 & 20570.98 & 72590.85 & 52019.87 \\
\hline $\begin{array}{l}\text { Total in year }{ }^{+1} \\
\text { (accumulated) }\end{array}$ & 6476.68 & 0.00 & & 6476.68 & 0.00 & \\
\hline Income/year & & & & & & 3715.71 \\
\hline
\end{tabular}

For year ${ }^{+2}$ Bamboo

\begin{tabular}{lrrrrrr}
\hline Lifetime & $\begin{array}{c}\text { Costs } \\
\text { (nominal) }\end{array}$ & $\begin{array}{c}\text { Revenue } \\
\text { (nominal) }\end{array}$ & $\begin{array}{c}\text { Net } \\
\text { income } \\
\text { (nominal) }\end{array}$ & $\begin{array}{c}\text { Present } \\
\text { cash flow } \\
\text { (Costs) } \\
\text { (nominal) }\end{array}$ & $\begin{array}{r}\text { Present } \\
\text { cash flow } \\
\text { (Revenue) } \\
\text { (Nominal) }\end{array}$ & $\begin{array}{c}\text { Present cash } \\
\text { flow (Net } \\
\text { income) } \\
\text { (Nominal) }\end{array}$ \\
\hline Year $^{+1}$ & 6476.68 & 0.00 & -6476.68 & 7059.58 & 0.00 & -7059.58 \\
Year $^{+2}$ & 2148.23 & 0.00 & -2148.23 & 2148.23 & 0.00 & -2148.23 \\
Year $^{+3}$ & 2102.69 & 0.00 & -2102.69 & 1929.07 & 0.00 & -1929.07 \\
Year $^{+4}$ & 1782.03 & 0.00 & -1782.03 & 1499.90 & 0.00 & -1499.90 \\
Year $^{+5}$ & 1782.03 & 5573.33 & 3791.30 & 1376.05 & 4303.64 & 2927.58 \\
Year $^{+6}$ & 1782.03 & 8253.33 & 6471.30 & 1262.43 & 5846.87 & 4584.43 \\
Year $^{+7}$ & 1782.03 & 13733.33 & 11951.30 & 1158.20 & 8925.72 & 7767.53 \\
Year $^{+8}$ & 1782.03 & 17946.67 & 16164.64 & 1062.57 & 10701.01 & 9638.44 \\
Year $^{+9}$ & 1782.03 & 18346.67 & 16564.64 & 974.83 & 10036.25 & 9061.42 \\
Year $^{+10}$ & 1782.03 & 18346.67 & 16564.64 & 894.34 & 9207.57 & 8313.23 \\
Year $^{+11}$ & 1835.67 & 19946.67 & 18111.00 & 845.19 & 9184.00 & 8338.81
\end{tabular}




\begin{tabular}{lrrrrrr} 
Year $^{+12}$ & 1835.67 & 19146.67 & 17311.00 & 775.41 & 8087.76 & 7312.35 \\
Year $^{+13}$ & 1902.67 & 19146.67 & 17244.00 & 737.35 & 7419.96 & 6682.62 \\
Year $^{+14}$ & 1966.65 & 15220.00 & 13253.35 & 699.21 & 5411.24 & 4712.03 \\
\hline Total & 30742.47 & 155660.00 & 124917.53 & 22422.37 & 79124.03 & 56701.66 \\
\hline $\begin{array}{l}\text { Total in year } \\
\text { (accumulated) }\end{array}$ & 8624.91 & 0.00 & & 9207.81 & 0.00 & \\
Income/year & & & & & & 4050.12 \\
\hline
\end{tabular}

For year ${ }^{+3}$ Bamboo

\begin{tabular}{|c|c|c|c|c|c|c|}
\hline Lifetime & $\begin{array}{c}\text { Costs } \\
\text { (nominal) }\end{array}$ & $\begin{array}{l}\text { Revenue } \\
\text { (nominal) }\end{array}$ & $\begin{array}{c}\text { Net } \\
\text { income } \\
\text { (nominal) }\end{array}$ & $\begin{array}{l}\text { Present } \\
\text { cash flow } \\
\text { (Costs) } \\
\text { (nominal) }\end{array}$ & $\begin{array}{c}\text { Present } \\
\text { cash flow } \\
\text { (Revenue) } \\
\text { (Nominal) }\end{array}$ & $\begin{array}{c}\text { Present cash } \\
\text { flow (Net } \\
\text { income) } \\
\text { (Nominal) }\end{array}$ \\
\hline Year $^{+1}$ & 6476.68 & 0.00 & -6476.68 & 7694.94 & 0.00 & -7694.94 \\
\hline Year $^{+2}$ & 2148.23 & 0.00 & -2148.23 & 2341.57 & 0.00 & -2341.57 \\
\hline Year $^{+3}$ & 2102.69 & 0.00 & -2102.69 & 2102.69 & 0.00 & -2102.69 \\
\hline Year $^{+4}$ & 1782.03 & 0.00 & -1782.03 & 1634.89 & 0.00 & -1634.89 \\
\hline Year $^{+5}$ & 1782.03 & 5573.33 & 3791.30 & 1499.90 & 4690.96 & 3191.06 \\
\hline Year $^{+6}$ & 1782.03 & 8253.33 & 6471.30 & 1376.05 & 6373.09 & 4997.03 \\
\hline Year $^{+7}$ & 1782.03 & 13733.33 & 11951.30 & 1262.43 & 9729.04 & 8466.60 \\
\hline Year $^{+8}$ & 1782.03 & 17946.67 & 16164.64 & 1158.20 & 11664.10 & 10505.90 \\
\hline Year $^{+9}$ & 1782.03 & 18346.67 & 16564.64 & 1062.57 & 10939.52 & 9876.95 \\
\hline Year $^{+10}$ & 1782.03 & 18346.67 & 16564.64 & 974.83 & 10036.25 & 9061.42 \\
\hline Year $^{+11}$ & 1835.67 & 19946.67 & 18111.00 & 921.26 & 10010.56 & 9089.30 \\
\hline Year $^{+12}$ & 1835.67 & 19146.67 & 17311.00 & 845.19 & 8815.66 & 7970.46 \\
\hline Year $^{+13}$ & 1902.67 & 19146.67 & 17244.00 & 803.71 & 8087.76 & 7284.05 \\
\hline Year $^{+14}$ & 1966.65 & 15220.00 & 13253.35 & 762.14 & 5898.25 & 5136.11 \\
\hline Total & 30742.47 & 155660.00 & 124917.53 & 24440.38 & 86245.19 & 61804.81 \\
\hline $\begin{array}{l}\text { Total in year }{ }^{+3} \\
\text { (accumulated) }\end{array}$ & 10727.60 & 0.00 & & 12139.20 & 0.00 & \\
\hline Income/year & & & & & & 4414.63 \\
\hline
\end{tabular}

For year ${ }^{+4}$ Bamboo

\begin{tabular}{lcrrrrr}
\hline Lifetime & $\begin{array}{c}\text { Costs } \\
\text { (nominal) }\end{array}$ & $\begin{array}{c}\text { Revenue } \\
\text { (nominal) }\end{array}$ & $\begin{array}{c}\text { Net } \\
\text { income } \\
\text { (nominal) }\end{array}$ & $\begin{array}{c}\text { Present } \\
\text { cash flow } \\
\text { (Costs) } \\
\text { (nominal) }\end{array}$ & $\begin{array}{c}\text { Present } \\
\text { cash flow } \\
\text { (Revenue) } \\
\text { (Nominal) }\end{array}$ & $\begin{array}{c}\text { Present cash } \\
\text { flow (Net } \\
\text { income) } \\
\text { (Nominal) }\end{array}$ \\
\hline Year $^{+1}$ & 6476.68 & 0.00 & -6476.68 & 8387.49 & 0.00 & -8387.49 \\
Year $^{+2}$ & 2148.23 & 0.00 & -2148.23 & 2552.31 & 0.00 & -2552.31 \\
Year $^{+3}$ & 2102.69 & 0.00 & -2102.69 & 2291.93 & 0.00 & -2291.93 \\
Year $^{+4}$ & 1782.03 & 0.00 & -1782.03 & 1782.03 & 0.00 & -1782.03
\end{tabular}




\begin{tabular}{|c|c|c|c|c|c|c|}
\hline Year $^{+5}$ & 1782.03 & 5573.33 & 3791.30 & 1634.89 & 5113.15 & 3478.26 \\
\hline Year $^{+6}$ & 1782.03 & 8253.33 & 6471.30 & 1499.90 & 6946.67 & 5446.77 \\
\hline Year $^{+7}$ & 1782.03 & 13733.33 & 11951.30 & 1376.05 & 10604.65 & 9228.60 \\
\hline Year $^{+8}$ & 1782.03 & 17946.67 & 16164.64 & 1262.43 & 12713.87 & 11451.44 \\
\hline Year $^{+9}$ & 1782.03 & 18346.67 & 16564.64 & 1158.20 & 11924.07 & 10765.88 \\
\hline Year ${ }^{+10}$ & 1782.03 & 18346.67 & 16564.64 & 1062.57 & 10939.52 & 9876.95 \\
\hline Year $^{+11}$ & 1835.67 & 19946.67 & 18111.00 & 1004.17 & 10911.51 & 9907.34 \\
\hline Year $^{+12}$ & 1835.67 & 19146.67 & 17311.00 & 921.26 & 9609.07 & 8687.81 \\
\hline Year $^{+13}$ & 1902.67 & 19146.67 & 17244.00 & 876.04 & 8815.66 & 7939.62 \\
\hline Year $^{+14}$ & 1966.65 & 15220.00 & 13253.35 & 830.73 & 6429.09 & 5598.36 \\
\hline Total & 30742.47 & 155660.00 & 124917.53 & 26640.02 & 94007.26 & 67367.24 \\
\hline $\begin{array}{l}\text { Total in year }{ }^{+4} \\
\text { (accumulated) }\end{array}$ & 12509.63 & 0.00 & & 15013.76 & 0.00 & \\
\hline Income/year & & & & & & 4811.95 \\
\hline
\end{tabular}

For year ${ }^{+5}$ Bamboo

\begin{tabular}{|c|c|c|c|c|c|c|}
\hline Lifetime & $\begin{array}{c}\text { Costs } \\
\text { (nominal) }\end{array}$ & $\begin{array}{l}\text { Revenue } \\
\text { (nominal) }\end{array}$ & $\begin{array}{c}\text { Net } \\
\text { income } \\
\text { (nominal) }\end{array}$ & $\begin{array}{l}\text { Present } \\
\text { cash flow } \\
\text { (Costs) } \\
\text { (nominal) }\end{array}$ & $\begin{array}{c}\text { Present } \\
\text { cash flow } \\
\text { (Revenue) } \\
\text { (Nominal) }\end{array}$ & $\begin{array}{c}\text { Present cash } \\
\text { flow (Net } \\
\text { income) } \\
\text { (Nominal) }\end{array}$ \\
\hline Year $^{+1}$ & 6476.68 & 0 & -6476.68 & 9142.36 & 0.00 & -9142.36 \\
\hline Year $^{+2}$ & 2148.23 & 0 & -2148.23 & 2782.02 & 0.00 & -2782.02 \\
\hline Year $^{+3}$ & 2102.69 & 0 & -2102.69 & 2498.21 & 0.00 & -2498.21 \\
\hline Year $^{+4}$ & 1782.03 & 0 & -1782.03 & 1942.41 & 0.00 & -1942.41 \\
\hline Year $^{+5}$ & 1782.03 & 5573.33 & 3791.30 & 1782.03 & 5573.33 & 3791.30 \\
\hline Year $^{+6}$ & 1782.03 & 8253.33 & 6471.30 & 1634.89 & 7571.87 & 5936.98 \\
\hline Year $^{+7}$ & 1782.03 & 13733.33 & 11951.30 & 1499.90 & 11559.07 & 10059.17 \\
\hline Year $^{+8}$ & 1782.03 & 17946.67 & 16164.64 & 1376.05 & 13858.12 & 12482.07 \\
\hline Year $^{+9}$ & 1782.03 & 18346.67 & 16564.64 & 1262.43 & 12997.24 & 11734.81 \\
\hline Year $^{+10}$ & 1782.03 & 18346.67 & 16564.64 & 1158.20 & 11924.07 & 10765.88 \\
\hline Year ${ }^{+11}$ & 1835.67 & 19946.67 & 18111.00 & 1094.55 & 11893.55 & 10799.00 \\
\hline Year $^{+12}$ & 1835.67 & 19146.67 & 17311.00 & 1004.17 & 10473.88 & 9469.71 \\
\hline Year $^{+13}$ & 1902.67 & 19146.67 & 17244.00 & 954.89 & 9609.07 & 8654.18 \\
\hline Year $^{+14}$ & 1966.65 & 15220.00 & 13253.35 & 905.50 & 7007.71 & 6102.21 \\
\hline Total & 30742.47 & 155660.00 & 124917.53 & 29037.62 & 102467.91 & 73430.29 \\
\hline $\begin{array}{l}\text { Total in year } \\
\text { (accumulated) }\end{array}$ & 14291.66 & 0.00 & & 18147.03 & 0.00 & \\
\hline Income/year & & & & & & 5245.02 \\
\hline
\end{tabular}


For year ${ }^{+6}$ Bamboo

\begin{tabular}{|c|c|c|c|c|c|c|}
\hline Lifetime & $\begin{array}{c}\text { Costs } \\
\text { (nominal) }\end{array}$ & $\begin{array}{l}\text { Revenue } \\
\text { (nominal) }\end{array}$ & $\begin{array}{c}\text { Net } \\
\text { income } \\
\text { (nominal) }\end{array}$ & $\begin{array}{c}\text { Present } \\
\text { cash flow } \\
\text { (Costs) } \\
\text { (nominal) }\end{array}$ & $\begin{array}{c}\text { Present } \\
\text { cash flow } \\
\text { (Revenue) } \\
\text { (Nominal) }\end{array}$ & $\begin{array}{c}\text { Present cash } \\
\text { flow (Net } \\
\text { income) } \\
\text { (Nominal) }\end{array}$ \\
\hline Year $^{+1}$ & 6476.68 & 0.00 & -6476.68 & 9965.17 & 0.00 & -9965.17 \\
\hline Year $^{+2}$ & 2148.23 & 0.00 & -2148.23 & 3032.40 & 0.00 & -3032.40 \\
\hline Year $^{+3}$ & 2102.69 & 0.00 & -2102.69 & 3526.42 & 0.00 & -3526.42 \\
\hline Year $^{+4}$ & 1782.03 & 0.00 & -1782.03 & 2117.23 & 0.00 & -2117.23 \\
\hline Year $^{+5}$ & 1782.03 & 5573.33 & 3791.30 & 1942.41 & 6074.93 & 4132.52 \\
\hline Year $^{+6}$ & 1782.03 & 8253.33 & 6471.30 & 1782.03 & 8253.33 & 6471.30 \\
\hline Year $^{+7}$ & 1782.03 & 13733.33 & 11951.30 & 1634.89 & 12599.39 & 10964.50 \\
\hline Year $^{+8}$ & 1782.03 & 17946.67 & 16164.64 & 1499.90 & 15105.35 & 13605.45 \\
\hline Year $^{+9}$ & 1782.03 & 18346.67 & 16564.64 & 1376.05 & 14166.99 & 12790.94 \\
\hline Year $^{+10}$ & 1782.03 & 18346.67 & 16564.64 & 1262.43 & 12997.24 & 11734.81 \\
\hline Year ${ }^{+11}$ & 1835.67 & 19946.67 & 18111.00 & 1193.06 & 12963.96 & 11770.91 \\
\hline Year $^{+12}$ & 1835.67 & 19146.67 & 17311.00 & 1094.55 & 11416.53 & 10321.98 \\
\hline Year ${ }^{+13}$ & 1902.67 & 19146.67 & 17244.00 & 1040.83 & 10473.88 & 9433.06 \\
\hline Year $^{+14}$ & 1966.65 & 15220.00 & 13253.35 & 987.00 & 7638.40 & 6651.41 \\
\hline Total & 30742.47 & 155660.00 & 124917.53 & 32454.38 & 111690.02 & 79235.64 \\
\hline $\begin{array}{l}\text { Total in year }{ }^{+6} \\
\text { (accumulated) }\end{array}$ & 16073.69 & 5573.33 & & 22365.67 & 6074.93 & \\
\hline Income/year & & & & & & 5659.69 \\
\hline
\end{tabular}

For year ${ }^{+7}$ Bamboo

\begin{tabular}{lrrrrrr}
\hline Lifetime & $\begin{array}{c}\text { Costs } \\
\text { (nominal) }\end{array}$ & $\begin{array}{c}\text { Revenue } \\
\text { (nominal) }\end{array}$ & $\begin{array}{c}\text { Net } \\
\text { income } \\
\text { (nominal) }\end{array}$ & $\begin{array}{c}\text { Present } \\
\text { cash flow } \\
\text { (Costs) } \\
\text { (nominal) }\end{array}$ & $\begin{array}{c}\text { Present } \\
\text { cash flow } \\
\text { (Revenue) } \\
\text { (Nominal) }\end{array}$ & $\begin{array}{c}\text { Present cash } \\
\text { flow (Net } \\
\text { income) } \\
\text { (Nominal) }\end{array}$ \\
\hline Year $^{+1}$ & 6476.68 & 0 & -6476.68 & 10862.04 & 0.00 & -10862.04 \\
Year $^{+2}$ & 2148.23 & 0 & -2148.23 & 3305.32 & 0.00 & -3305.32 \\
Year $^{+3}$ & 2102.69 & 0 & -2102.69 & 2968.12 & 0.00 & -2968.12 \\
Year $^{+4}$ & 1782.03 & 0 & -1782.03 & 2307.78 & 0.00 & -2307.78 \\
Year $^{+5}$ & 1782.03 & 5573.33 & 3791.30 & 2117.23 & 6621.68 & 4504.45 \\
Year $^{+6}$ & 1782.03 & 8253.33 & 6471.30 & 1942.41 & 8996.13 & 7053.72 \\
Year $^{+7}$ & 1782.03 & 13733.33 & 11951.30 & 1782.03 & 13733.33 & 11951.30 \\
Year $^{+8}$ & 1782.03 & 17946.67 & 16164.64 & 1634.89 & 16464.83 & 14829.94 \\
Year $^{+9}$ & 1782.03 & 18346.67 & 16564.64 & 1499.90 & 15442.02 & 13942.12 \\
Year $^{+10}$ & 1782.03 & 18346.67 & 16564.64 & 1376.05 & 14166.99 & 12790.94 \\
Year $^{+11}$ & 1835.67 & 19946.67 & 18111.00 & 1300.43 & 14130.72 & 12830.29
\end{tabular}




\begin{tabular}{lrrrrrr} 
Year $^{+12}$ & 1835.67 & 19146.67 & 17311.00 & 1193.06 & 12444.02 & 11250.96 \\
Year $^{+13}$ & 1902.67 & 19146.67 & 17244.00 & 1134.50 & 11416.53 & 10282.03 \\
Year $^{+14}$ & 1966.65 & 15220.00 & 13253.35 & 1075.82 & 8325.86 & 7250.04 \\
\hline Total & 30742.47 & 155660.00 & 124917.53 & 34499.59 & 121742.13 & 87242.53 \\
\hline $\begin{array}{l}\text { Total in year } \\
\text { (accumulated) }\end{array}$ & 17855.72 & 13826.67 & & 25284.93 & 15617.81 & \\
\begin{tabular}{l} 
Income/year \\
\hline
\end{tabular} & & & & & & 6231.61 \\
\hline
\end{tabular}

For year ${ }^{+8}$ Bamboo

\begin{tabular}{|c|c|c|c|c|c|c|}
\hline Lifetime & $\begin{array}{c}\text { Costs } \\
\text { (nominal) }\end{array}$ & $\begin{array}{l}\text { Revenue } \\
\text { (nominal) }\end{array}$ & $\begin{array}{c}\text { Net } \\
\text { income } \\
\text { (nominal) }\end{array}$ & $\begin{array}{l}\text { Present } \\
\text { cash flow } \\
\text { (Costs) } \\
\text { (nominal) }\end{array}$ & $\begin{array}{l}\text { Present } \\
\text { cash flow } \\
\text { (Revenue) } \\
\text { (Nominal) }\end{array}$ & $\begin{array}{l}\text { Present cash } \\
\text { flow (Net } \\
\text { income) } \\
\text { (Nominal) }\end{array}$ \\
\hline Year $^{+1}$ & 6476.68 & 0.00 & -6476.68 & 11839.62 & 0.00 & -11839.62 \\
\hline Year $^{+2}$ & 2148.23 & 0.00 & -2148.23 & 3602.80 & 0.00 & -3602.80 \\
\hline Year $^{+3}$ & 2102.69 & 0.00 & -2102.69 & 3235.25 & 0.00 & -3235.25 \\
\hline Year $^{+4}$ & 1782.03 & 0.00 & -1782.03 & 2515.48 & 0.00 & -2515.48 \\
\hline Year $^{+5}$ & 1782.03 & 5573.33 & 3791.30 & 2307.78 & 7217.63 & 4909.85 \\
\hline Year $^{+6}$ & 1782.03 & 8253.33 & 6471.30 & 2117.23 & 9805.79 & 7688.56 \\
\hline Year $^{+7}$ & 1782.03 & 13733.33 & 11951.30 & 1942.41 & 14969.33 & 13026.92 \\
\hline Year $^{+8}$ & 1782.03 & 17946.67 & 16164.64 & 1782.03 & 17946.67 & 16164.64 \\
\hline Year $^{+9}$ & 1782.03 & 18346.67 & 16564.64 & 1634.89 & 16831.80 & 15196.91 \\
\hline Year ${ }^{+10}$ & 1782.03 & 18346.67 & 16564.64 & 1499.90 & 15442.02 & 13942.12 \\
\hline Year $^{+11}$ & 1835.67 & 19946.67 & 18111.00 & 1417.47 & 15402.49 & 13985.01 \\
\hline Year $^{+12}$ & 1835.67 & 19146.67 & 17311.00 & 1300.43 & 13563.98 & 12263.55 \\
\hline Year $^{+13}$ & 1902.67 & 19146.67 & 17244.00 & 1236.60 & 12444.02 & 11207.41 \\
\hline Year $^{+14}$ & 1966.65 & 15220.00 & 13253.35 & 1172.65 & 9075.19 & 7902.54 \\
\hline Total & 30742.47 & 155660.00 & 124917.53 & 37604.56 & 132698.92 & 95094.36 \\
\hline $\begin{array}{l}\text { Total in year }{ }^{+8} \\
\text { (accumulated) }\end{array}$ & 19637.75 & 27560.00 & & 29342.60 & 31992.75 & \\
\hline Income/year & & & & & & 6792.45 \\
\hline
\end{tabular}

For year $^{+9}$ Bamboo

\begin{tabular}{|c|c|c|c|c|c|c|}
\hline Lifetime & $\begin{array}{c}\text { Costs } \\
\text { (nominal) }\end{array}$ & $\begin{array}{l}\text { Revenue } \\
\text { (nominal) }\end{array}$ & $\begin{array}{c}\text { Net } \\
\text { income } \\
\text { (nominal) }\end{array}$ & $\begin{array}{l}\text { Present cash } \\
\text { flow (Costs) } \\
\text { (nominal) }\end{array}$ & $\begin{array}{c}\text { Present cash } \\
\text { flow } \\
\text { (Revenue) } \\
\text { (Nominal) }\end{array}$ & $\begin{array}{c}\text { Present } \\
\text { cash flow } \\
(\text { Net } \\
\text { income) } \\
\text { (Nominal) }\end{array}$ \\
\hline Year $^{+1}$ & 6476.68 & 0.00 & -6476.68 & 12905.19 & 0.00 & -12905.19 \\
\hline Year $^{+2}$ & 2148.23 & 0.00 & -2148.23 & 3927.05 & 0.00 & -3927.05 \\
\hline Year $^{+3}$ & 2102.69 & 0.00 & -2102.69 & 3526.42 & 0.00 & -3526.42 \\
\hline
\end{tabular}




\begin{tabular}{lrrrrrr} 
Year $^{+4}$ & 1782.03 & 0.00 & -1782.03 & 2741.87 & 0.00 & -2741.87 \\
Year $^{+5}$ & 1782.03 & 5573.33 & 3791.30 & 2515.48 & 7867.21 & 5351.73 \\
Year $^{+6}$ & 1782.03 & 8253.33 & 6471.30 & 2307.78 & 10688.31 & 8380.53 \\
Year $^{+7}$ & 1782.03 & 13733.33 & 11951.30 & 2117.23 & 16316.57 & 14199.34 \\
Year $^{+8}$ & 1782.03 & 17946.67 & 16164.64 & 1942.41 & 19561.87 & 17619.45 \\
Year $^{+9}$ & 1782.03 & 18346.67 & 16564.64 & 1782.03 & 18346.67 & 16564.64 \\
Year $^{+10}$ & 1782.03 & 18346.67 & 16564.64 & 1634.89 & 16831.80 & 15196.91 \\
Year $^{+11}$ & 1835.67 & 19946.67 & 18111.00 & 1545.05 & 16788.71 & 15243.66 \\
Year $^{+12}$ & 1835.67 & 19146.67 & 17311.00 & 1417.47 & 14784.74 & 13367.27 \\
Year $^{+13}$ & 1902.67 & 19146.67 & 17244.00 & 1347.90 & 13563.98 & 12216.08 \\
Year $^{+14}$ & 1966.65 & 15220.00 & 13253.35 & 1278.19 & 9891.96 & 8613.77 \\
\hline Total & 30742.47 & 155660.00 & 124917.53 & 40988.97 & 144641.82 & 103652.85 \\
\hline Total in year & & & & & & \\
(accumulated) & 21419.78 & 45506.67 & & 33765.47 & 54433.96 & \\
Income/year & & & & & & 7403.78 \\
\hline
\end{tabular}

For year ${ }^{+10}$ Bamboo

\begin{tabular}{|c|c|c|c|c|c|c|}
\hline Lifetime & $\begin{array}{c}\text { Costs } \\
\text { (nominal) }\end{array}$ & $\begin{array}{l}\text { Revenue } \\
\text { (nominal) }\end{array}$ & $\begin{array}{c}\text { Net } \\
\text { income } \\
\text { (nominal) }\end{array}$ & $\begin{array}{l}\text { Present } \\
\text { cash flow } \\
\text { (Costs) } \\
\text { (nominal) }\end{array}$ & $\begin{array}{l}\text { Present } \\
\text { cash flow } \\
\text { (Revenue) } \\
\text { (Nominal) }\end{array}$ & $\begin{array}{c}\text { Present cash } \\
\text { flow (Net } \\
\text { income) } \\
\text { (Nominal) }\end{array}$ \\
\hline Year $^{+1}$ & 6476.68 & 0.00 & -6476.68 & 14066.66 & 0.00 & -14066.66 \\
\hline Year $^{+2}$ & 2148.23 & 0.00 & -2148.23 & 4280.48 & 0.00 & -4280.48 \\
\hline Year $^{+3}$ & 2102.69 & 0.00 & -2102.69 & 3843.80 & 0.00 & -3843.80 \\
\hline Year $^{+4}$ & 1782.03 & 0.00 & -1782.03 & 2988.64 & 0.00 & -2988.64 \\
\hline Year $^{+5}$ & 1782.03 & 5573.33 & 3791.30 & 2741.87 & 8575.26 & 5833.39 \\
\hline Year $^{+6}$ & 1782.03 & 8253.33 & 6471.30 & 2515.48 & 11650.25 & 9134.77 \\
\hline Year $^{+7}$ & 1782.03 & 13733.33 & 11951.30 & 2307.78 & 17785.06 & 15477.28 \\
\hline Year $^{+8}$ & 1782.03 & 17946.67 & 16164.64 & 2117.23 & 21322.43 & 19205.20 \\
\hline Year $^{+9}$ & 1782.03 & 18346.67 & 16564.64 & 1942.41 & 19997.87 & 18055.45 \\
\hline Year ${ }^{+10}$ & 1782.03 & 18346.67 & 16564.64 & 1782.03 & 18346.67 & 16564.64 \\
\hline Year $^{+11}$ & 1835.67 & 19946.67 & 18111.00 & 1684.10 & 18299.69 & 16615.59 \\
\hline Year $^{+12}$ & 1835.67 & 19146.67 & 17311.00 & 1545.05 & 16115.37 & 14570.32 \\
\hline Year $^{+13}$ & 1902.67 & 19146.67 & 17244.00 & 1469.21 & 14784.74 & 13315.53 \\
\hline Year $^{+14}$ & 1966.65 & 15220.00 & 13253.35 & 1393.22 & 10782.23 & 9389.01 \\
\hline Total & 30742.47 & 155660 & 124917.53 & 44677.97 & 157659.58 & 112981.61 \\
\hline $\begin{array}{l}\text { Total in year } \\
\text { (accumulated) }\end{array}$ & 23201.81 & 63853.33 & & 38586.39 & 79330.88 & \\
\hline Income/year & & & & & & 8070.11 \\
\hline
\end{tabular}


For year ${ }^{+11}$ Bamboo

\begin{tabular}{|c|c|c|c|c|c|c|}
\hline Lifetime & $\begin{array}{c}\text { Costs } \\
\text { (nominal) }\end{array}$ & $\begin{array}{l}\text { Revenue } \\
\text { (nominal) }\end{array}$ & $\begin{array}{c}\text { Net } \\
\text { income } \\
\text { (nominal) }\end{array}$ & $\begin{array}{c}\text { Present } \\
\text { cash flow } \\
\text { (Costs) } \\
\text { (nominal) }\end{array}$ & $\begin{array}{c}\text { Present } \\
\text { cash flow } \\
\text { (Revenue) } \\
\text { (Nominal) }\end{array}$ & $\begin{array}{c}\text { Present cash } \\
\text { flow (Net } \\
\text { income) } \\
\text { (Nominal) }\end{array}$ \\
\hline Year $^{+1}$ & 6476.68 & 0.00 & -6476.68 & 15332.66 & 0.00 & -15332.66 \\
\hline Year $^{+2}$ & 2148.23 & 0.00 & -2148.23 & 4665.73 & 0.00 & -4665.73 \\
\hline Year $^{+3}$ & 2102.69 & 0.00 & -2102.69 & 4189.74 & 0.00 & -4189.74 \\
\hline Year $^{+4}$ & 1782.03 & 0.00 & -1782.03 & 3257.62 & 0.00 & -3257.62 \\
\hline Year $^{+5}$ & 1782.03 & 5573.33 & 3791.30 & 2988.64 & 9347.04 & 6358.40 \\
\hline Year $^{+6}$ & 1782.03 & 8253.33 & 6471.30 & 2741.87 & 12698.78 & 9956.90 \\
\hline Year $^{+7}$ & 1782.03 & 13733.33 & 11951.30 & 2515.48 & 19385.72 & 16870.24 \\
\hline Year $^{+8}$ & 1782.03 & 17946.67 & 16164.64 & 2307.78 & 23241.45 & 20933.67 \\
\hline Year $^{+9}$ & 1782.03 & 18346.67 & 16564.64 & 2117.23 & 21797.67 & 19680.44 \\
\hline Year $^{+10}$ & 1782.03 & 18346.67 & 16564.64 & 1942.41 & 19997.87 & 18055.45 \\
\hline Year $^{+11}$ & 1835.67 & 19946.67 & 18111.00 & 1835.67 & 19946.67 & 18111.00 \\
\hline Year $^{+12}$ & 1835.67 & 19146.67 & 17311.00 & 1684.10 & 17565.75 & 15881.65 \\
\hline Year $^{+13}$ & 1902.67 & 19146.67 & 17244.00 & 1601.44 & 16115.37 & 14513.93 \\
\hline Year $^{+14}$ & 1966.65 & 15220.00 & 13253.35 & 1518.61 & 11752.63 & 10234.02 \\
\hline Total & 30742.47 & 155660.00 & 124917.53 & 48698.99 & 171848.94 & 123149.95 \\
\hline $\begin{array}{l}\text { Total in year } \\
\text { (accumulated) }\end{array}$ & 25037.48 & 82200.00 & & 43894.84 & 106468.53 & \\
\hline Income/year & & & & & & 8796.43 \\
\hline
\end{tabular}

For year $^{+12}$ Bamboo

\begin{tabular}{lrrrrrr}
\hline Lifetime & $\begin{array}{c}\text { Costs } \\
\text { (nominal) }\end{array}$ & $\begin{array}{c}\text { Revenue } \\
\text { (nominal) }\end{array}$ & $\begin{array}{c}\text { Net } \\
\text { income } \\
\text { (nominal) }\end{array}$ & $\begin{array}{c}\text { Present } \\
\text { cash flow } \\
\text { (Costs) } \\
\text { (nominal) }\end{array}$ & $\begin{array}{r}\text { Present } \\
\text { cash flow } \\
\text { (Revenue) } \\
\text { (Nominal) }\end{array}$ & $\begin{array}{c}\text { Present cash } \\
\text { flow (Net } \\
\text { income) } \\
\text { (Nominal) }\end{array}$ \\
\hline Year $^{+1}$ & 6476.68 & 0.00 & -6476.68 & 16712.60 & 0.00 & -16712.60 \\
Year $^{+2}$ & 2148.23 & 0.00 & -2148.23 & 5085.64 & 0.00 & -5085.64 \\
Year $^{+3}$ & 2102.69 & 0.00 & -2102.69 & 4566.82 & 0.00 & -4566.82 \\
Year $^{+4}$ & 1782.03 & 0.00 & -1782.03 & 3550.81 & 0.00 & -3550.81 \\
Year $^{+5}$ & 1782.03 & 5573.33 & 3791.30 & 3257.62 & 10188.27 & 6930.65 \\
Year $^{+6}$ & 1782.03 & 8253.33 & 6471.30 & 2988.64 & 13841.67 & 10853.02 \\
Year $^{+7}$ & 1782.03 & 13733.33 & 11951.30 & 2741.87 & 21130.44 & 18388.56 \\
Year $^{+8}$ & 1782.03 & 17946.67 & 16164.64 & 2515.48 & 25333.18 & 22817.70 \\
Year $^{+9}$ & 1782.03 & 18346.67 & 16564.64 & 2307.78 & 23759.47 & 21451.68 \\
Year $^{+10}$ & 1782.03 & 18346.67 & 16564.64 & 2117.23 & 21797.67 & 19680.44 \\
Year $^{+11}$ & 1835.67 & 19946.67 & 18111.00 & 2000.88 & 21741.87 & 19740.99
\end{tabular}




\begin{tabular}{lrrrrrr} 
Year $^{+12}$ & 1835.67 & 19146.67 & 17311.00 & 1835.67 & 19146.67 & 17311.00 \\
Year $^{+13}$ & 1902.67 & 19146.67 & 17244.00 & 1745.57 & 17565.75 & 15820.18 \\
Year $^{+14}$ & 1966.65 & 15220.00 & 13253.35 & 1655.29 & 12810.37 & 11155.08 \\
\hline Total & 30742.47 & 155660.00 & 124917.53 & 53081.90 & 187315.35 & 134233.45 \\
\hline $\begin{array}{l}\text { Total in year } \\
\text { (accumulated) }\end{array}$ & 26873.15 & 102146.67 & & 49681.04 & 137792.56 & \\
Income/year & & & & & & 9588.10 \\
\hline
\end{tabular}

\begin{tabular}{|c|c|c|c|c|c|c|}
\hline \multicolumn{7}{|c|}{ For year ${ }^{+13}$ Bamboo } \\
\hline Lifetime & $\begin{array}{c}\text { Costs } \\
\text { (nominal) }\end{array}$ & $\begin{array}{l}\text { Revenue } \\
\text { (nominal) }\end{array}$ & $\begin{array}{c}\text { Net } \\
\text { income } \\
\text { (nominal) }\end{array}$ & $\begin{array}{c}\text { Present } \\
\text { cash flow } \\
\text { (Costs) } \\
\text { (nominal) }\end{array}$ & $\begin{array}{c}\text { Present } \\
\text { cash flow } \\
\text { (Revenue) } \\
\text { (Nominal) }\end{array}$ & $\begin{array}{c}\text { Present cash } \\
\text { flow (Net } \\
\text { income) } \\
\text { (Nominal) }\end{array}$ \\
\hline Year $^{+1}$ & 6476.68 & 0.00 & -6476.68 & 18216.73 & 0.00 & -18216.73 \\
\hline Year $^{+2}$ & 2148.23 & 0.00 & -2148.23 & 5543.35 & 0.00 & -5543.35 \\
\hline Year $^{+3}$ & 2102.69 & 0.00 & -2102.69 & 4977.83 & 0.00 & -4977.83 \\
\hline Year $^{+4}$ & 1782.03 & 0.00 & -1782.03 & 3870.38 & 0.00 & -3870.38 \\
\hline Year $^{+5}$ & 1782.03 & 5573.33 & 3791.30 & 3550.81 & 11105.22 & 7554.41 \\
\hline Year $^{+6}$ & 1782.03 & 8253.33 & 6471.30 & 3257.62 & 15087.42 & 11829.80 \\
\hline Year $^{+7}$ & 1782.03 & 13733.33 & 11951.30 & 2988.64 & 23032.17 & 20043.53 \\
\hline Year $^{+8}$ & 1782.03 & 17946.67 & 16164.64 & 2741.87 & 27613.17 & 24871.30 \\
\hline Year $^{+9}$ & 1782.03 & 18346.67 & 16564.64 & 2515.48 & 25897.82 & 23382.34 \\
\hline Year $^{+10}$ & 1782.03 & 18346.67 & 16564.64 & 2307.78 & 23759.47 & 21451.68 \\
\hline Year $^{+11}$ & 1835.67 & 19946.67 & 18111.00 & 2180.96 & 23698.63 & 21517.68 \\
\hline Year $^{+12}$ & 1835.67 & 19146.67 & 17311.00 & 2000.88 & 20869.87 & 18868.99 \\
\hline Year $^{+13}$ & 1902.67 & 19146.67 & 17244.00 & 1902.67 & 19146.67 & 17244.00 \\
\hline Year ${ }^{+14}$ & 1966.65 & 15220.00 & 13253.35 & 1804.27 & 13963.30 & 12159.04 \\
\hline Total & 30742.47 & 155660.00 & 124917.53 & 57859.27 & 204173.73 & 146314.46 \\
\hline $\begin{array}{l}\text { Total in year } \\
\text { (accumulated) }\end{array}$ & 28775.82 & 121293.33 & & 56055.00 & 171063.76 & \\
\hline Income/year & & & & & & 10451.03 \\
\hline
\end{tabular}


For year ${ }^{+14}$ Bamboo

\begin{tabular}{|c|c|c|c|c|c|c|}
\hline Lifetime & $\begin{array}{c}\text { Costs } \\
\text { (nominal) }\end{array}$ & $\begin{array}{l}\text { Revenue } \\
\text { (nominal) }\end{array}$ & $\begin{array}{c}\text { Net } \\
\text { income } \\
\text { (nominal) }\end{array}$ & $\begin{array}{c}\text { Present } \\
\text { cash flow } \\
(\text { Costs }) \\
\text { (nominal) }\end{array}$ & $\begin{array}{c}\text { Present } \\
\text { cash flow } \\
\text { (Revenue) } \\
\text { (Nominal) }\end{array}$ & $\begin{array}{c}\text { Present cash } \\
\text { flow (Net } \\
\text { income) } \\
\text { (Nominal) }\end{array}$ \\
\hline Year $^{+1}$ & 6476.68 & 0.00 & -6476.68 & 19856.24 & 0.00 & -19856.24 \\
\hline Year $^{+2}$ & 2148.23 & 0.00 & -2148.23 & 6042.25 & 0.00 & -6042.25 \\
\hline Year $^{+3}$ & 2102.69 & 0.00 & -2102.69 & 5425.84 & 0.00 & -5425.84 \\
\hline Year $^{+4}$ & 1782.03 & 0.00 & -1782.03 & 4218.71 & 0.00 & -4218.71 \\
\hline Year $^{+5}$ & 1782.03 & 5573.33 & 3791.30 & 3870.38 & 12104.69 & 8234.31 \\
\hline Year $^{+6}$ & 1782.03 & 8253.33 & 6471.30 & 3550.81 & 16445.28 & 12894.48 \\
\hline Year $^{+7}$ & 1782.03 & 13733.33 & 11951.30 & 3257.62 & 25105.07 & 21847.45 \\
\hline Year $^{+8}$ & 1782.03 & 17946.67 & 16164.64 & 2988.64 & 30098.36 & 27109.71 \\
\hline Year $^{+9}$ & 1782.03 & 18346.67 & 16564.64 & 2741.87 & 28228.62 & 25486.75 \\
\hline Year $^{+10}$ & 1782.03 & 18346.67 & 16564.64 & 2515.48 & 25897.82 & 23382.34 \\
\hline Year $^{+11}$ & 1835.67 & 19946.67 & 18111.00 & 2377.25 & 25831.51 & 23454.27 \\
\hline Year $^{+12}$ & 1835.67 & 19146.67 & 17311.00 & 2180.96 & 22748.15 & 20567.20 \\
\hline Year $^{+13}$ & 1902.67 & 19146.67 & 17244.00 & 2073.91 & 20869.87 & 18795.96 \\
\hline Year $^{+14}$ & 1966.65 & 15220.00 & 13253.35 & 1966.65 & 15220.00 & 13253.35 \\
\hline Total & 30742.47 & 155660.00 & 124917.53 & 63066.61 & 222549.37 & 159482.76 \\
\hline $\begin{array}{l}\text { Total in year }{ }^{+14} \\
\text { (accumulated) }\end{array}$ & 30742.47 & 140440.00 & & 63066.61 & 207329.37 & \\
\hline Income/year & & & & & & 11391.63 \\
\hline
\end{tabular}


Appendix 6 Landslide damage cost from 2000 to 2010 in Maichau District

\begin{tabular}{|c|c|c|c|c|c|c|}
\hline $\begin{array}{c}\text { ID of } \\
\text { landslide }\end{array}$ & $\begin{array}{l}\text { Category of } \\
\text { landslide } \\
\text { susceptibility }\end{array}$ & $\begin{array}{l}\text { Category } \\
\quad \text { of } \\
\text { Integrated } \\
\text { LUP }\end{array}$ & $\begin{array}{l}\text { Individual } \\
\text { Landslide } \\
\text { Damage } \\
\text { Cost (LDC) } \\
\text { (VND Mil) }\end{array}$ & $\begin{array}{c}\text { Landslide } \\
\text { Damage Cost in } \\
\text { correctly } \\
\text { predicted area as } \\
\text { high } \\
\text { susceptibility } \\
\text { (VND Mil) }\end{array}$ & $\begin{array}{l}\text { Landslide } \\
\text { Damage } \\
\text { Cost in } \\
\text { wrongly } \\
\text { predicted } \\
\text { area (VND } \\
\text { Mil) }\end{array}$ & $\begin{array}{c}\text { Landslide } \\
\text { Damage Cost } \\
\text { in correctly } \\
\text { predicted area } \\
\text { as low } \\
\text { suitability } \\
\text { (VND Mil) } \\
\text { (ALDC) }\end{array}$ \\
\hline 1 & Moderate & Moderate & 25.84 & & 25.84 & \\
\hline 2 & High & Low & 20.00 & 20.00 & & 20.00 \\
\hline 3 & High & Low & 10.78 & 10.78 & & 10.78 \\
\hline \multirow[t]{2}{*}{4} & High & Moderate & 11.74 & 11.74 & & \\
\hline & High & Low & 109.00 & 109.00 & & 109.00 \\
\hline 5 & High & Low & 7.74 & 7.74 & & 7.74 \\
\hline 6 & Moderate & Moderate & 19.56 & & 19.56 & \\
\hline 7 & Moderate & Moderate & 16.50 & & 16.50 & \\
\hline 8 & Moderate & Moderate & 26.64 & & 26.64 & \\
\hline 9 & Moderate & Moderate & 5.80 & & 5.80 & \\
\hline \multirow[t]{2}{*}{10} & High & Moderate & 51.69 & 51.69 & & \\
\hline & High & Low & 645.90 & 645.90 & & 645.90 \\
\hline 11 & High & Low & 7.74 & 7.74 & & 7.74 \\
\hline 12 & High & Moderate & 10.66 & 10.66 & & \\
\hline 13 & High & Low & 5.22 & 5.22 & & 5.22 \\
\hline \multirow[t]{3}{*}{14} & High & Low & 38.68 & 38.68 & & 38.68 \\
\hline & High & Moderate & 51.69 & 51.69 & & \\
\hline & High & Low & 1156.00 & 1156.00 & & 1156.00 \\
\hline 15 & High & Low & 19.34 & 19.34 & & 19.34 \\
\hline 16 & High & Low & 96.71 & 96.71 & & 96.71 \\
\hline 17 & High & Low & 10.12 & 10.12 & & 10.12 \\
\hline 18 & High & Low & 2.03 & 2.03 & & 2.03 \\
\hline 19 & High & Low & 10.12 & 10.12 & & 10.12 \\
\hline 20 & Moderate & Moderate & 205.00 & & 205.00 & \\
\hline 21 & Moderate & Moderate & 121.44 & & 121.44 & \\
\hline 22 & Moderate & Moderate & 12.65 & & 12.65 & \\
\hline \multirow[t]{3}{*}{23} & Moderate & Moderate & 60.21 & & 60.21 & \\
\hline & Moderate & Moderate & 98.00 & & 98.00 & \\
\hline & Moderate & Moderate & 490.80 & & 490.80 & \\
\hline 24 & Moderate & Moderate & 2.53 & & 2.53 & \\
\hline 25 & High & Low & 3.87 & 3.87 & & 3.87 \\
\hline 26 & High & Low & 8.78 & 8.78 & & 8.78 \\
\hline 27 & High & Low & 7.52 & 7.52 & & 7.52 \\
\hline \multirow[t]{2}{*}{28} & High & Low & 25.30 & 25.30 & & 25.30 \\
\hline & High & Low & 25.07 & 25.07 & & 25.07 \\
\hline 29 & High & Low & 9.67 & 9.67 & & 9.67 \\
\hline 30 & Moderate & Moderate & 12.65 & & 12.65 & \\
\hline
\end{tabular}




\begin{tabular}{|c|c|c|c|c|c|c|}
\hline 31 & Moderate & Moderate & 12.65 & & 12.65 & \\
\hline 32 & Moderate & Moderate & 5.06 & & 5.06 & \\
\hline 33 & High & Moderate & 53.29 & 53.29 & & \\
\hline 34 & High & Low & 19.34 & 19.34 & & 19.34 \\
\hline 35 & High & Moderate & 31.00 & 31.00 & & \\
\hline \multirow[t]{3}{*}{36} & High & Low & 17.71 & 17.71 & & 17.71 \\
\hline & High & Moderate & 45.97 & 45.97 & & \\
\hline & High & Low & 9.67 & 9.67 & & 9.67 \\
\hline 37 & High & Moderate & 41.35 & 41.35 & & \\
\hline \multirow[t]{2}{*}{38} & High & Moderate & 26.64 & 26.64 & & \\
\hline & High & Low & 414.00 & 414.00 & & 414.00 \\
\hline 39 & High & Moderate & 13.79 & 13.79 & & \\
\hline 40 & High & Moderate & 21.70 & 21.70 & & \\
\hline 41 & High & Low & 9.67 & 9.67 & & 9.67 \\
\hline \multirow[t]{3}{*}{42} & High & Low & 58.02 & 58.02 & & 58.02 \\
\hline & High & Moderate & 51.69 & 51.69 & & \\
\hline & High & Moderate & 206.76 & 206.76 & & \\
\hline 43 & High & Moderate & 26.64 & 26.64 & & \\
\hline 44 & High & Moderate & 53.29 & 53.29 & & \\
\hline \multirow[t]{2}{*}{45} & High & Low & 87.04 & 87.04 & & 87.04 \\
\hline & High & Moderate & 51.69 & 51.69 & & \\
\hline 46 & High & Moderate & 7.83 & 7.83 & & \\
\hline 47 & High & Moderate & 67.20 & 67.20 & & \\
\hline 48 & High & Moderate & 91.93 & 91.93 & & \\
\hline 49 & High & Low & 38.68 & 38.68 & & 38.68 \\
\hline 50 & High & Moderate & 45.97 & 45.97 & & \\
\hline 51 & High & Moderate & 82.74 & 82.74 & & \\
\hline 52 & High & Moderate & 155.07 & 155.07 & & \\
\hline 53 & High & Moderate & 77.53 & 77.53 & & \\
\hline 54 & Moderate & Moderate & 137.90 & & 137.90 & \\
\hline 55 & Moderate & Moderate & 129.22 & & 129.22 & \\
\hline 56 & High & Low & 280.00 & 280.00 & & 280.00 \\
\hline 57 & Moderate & Moderate & 38.68 & & 38.68 & \\
\hline \multirow[t]{2}{*}{58} & Moderate & Moderate & 3.87 & 3.87 & & 3.87 \\
\hline & Moderate & Moderate & 353.00 & 353.00 & & 353.00 \\
\hline \multirow[t]{2}{*}{59} & High & Low & 12.65 & 12.65 & & 12.65 \\
\hline & High & Moderate & 51.69 & 51.69 & & \\
\hline \multirow[t]{2}{*}{60} & High & Moderate & 258.45 & 258.45 & & \\
\hline & High & Low & 912.80 & 912.80 & & 912.80 \\
\hline \multirow[t]{2}{*}{61} & High & Moderate & 4.60 & 4.60 & & \\
\hline & High & Low & 338.50 & 338.50 & & 338.50 \\
\hline 62 & High & Low & 1.93 & 1.93 & & 1.93 \\
\hline 63 & Moderate & Moderate & 4.08 & & 4.08 & \\
\hline 64 & Moderate & Moderate & 12.00 & & 12.00 & \\
\hline 65 & Moderate & Moderate & 231.20 & & 231.20 & \\
\hline 66 & Moderate & Moderate & 102.00 & & 102.00 & \\
\hline \multirow[t]{2}{*}{67} & High & Moderate & 6.89 & 6.89 & & \\
\hline & High & Low & 154.00 & 154.00 & & 154.00 \\
\hline
\end{tabular}




\begin{tabular}{|c|c|c|c|c|c|c|}
\hline \multirow[t]{2}{*}{68} & High & Moderate & 3.68 & 3.68 & & \\
\hline & High & Low & 389.20 & 389.20 & & 389.20 \\
\hline \multirow[t]{3}{*}{69} & Moderate & Moderate & 68.95 & & 68.95 & \\
\hline & Moderate & Moderate & 190.00 & & 190.00 & \\
\hline & Moderate & Moderate & 482.20 & & 482.20 & \\
\hline 70 & High & Low & 9.67 & 9.67 & & 9.67 \\
\hline 71 & High & Moderate & 10.66 & 10.66 & & \\
\hline 72 & High & Moderate & 9.19 & 9.19 & & \\
\hline 73 & High & Low & 19.34 & 19.34 & & 19.34 \\
\hline \multirow[t]{2}{*}{74} & High & Low & 25.07 & 25.07 & & 25.07 \\
\hline & High & Moderate & 39.13 & 39.13 & & \\
\hline 75 & High & Low & 2.90 & 2.90 & & 2.90 \\
\hline 76 & High & Low & 257.00 & 257.00 & & 257.00 \\
\hline 77 & High & Moderate & 19.56 & 19.56 & & \\
\hline 78 & High & Moderate & 26.64 & 26.64 & & \\
\hline 79 & High & Low & 1.25 & 1.25 & & 1.25 \\
\hline 80 & High & Moderate & 4.08 & 4.08 & & \\
\hline \multirow[t]{2}{*}{81} & High & Low & 75.90 & 75.90 & & 75.90 \\
\hline & High & Low & 9.67 & 9.67 & & 9.67 \\
\hline 82 & High & Low & 9.67 & 9.67 & & 9.67 \\
\hline \multirow[t]{2}{*}{83} & High & Moderate & 51.69 & 51.69 & & \\
\hline & High & Low & 633.30 & 633.30 & & 633.30 \\
\hline 84 & High & Moderate & 5.17 & 5.17 & & \\
\hline 85 & High & Moderate & 7.83 & 7.83 & & \\
\hline 86 & High & Moderate & 15.99 & 15.99 & & \\
\hline 87 & High & Low & 5.80 & 5.80 & & 5.80 \\
\hline 88 & High & Moderate & 26.64 & 26.64 & & \\
\hline 89 & High & Low & 12.54 & 12.54 & & 12.54 \\
\hline 90 & High & Low & 5.80 & 5.80 & & 5.80 \\
\hline 91 & High & Low & 9.67 & 9.67 & & 9.67 \\
\hline 92 & High & Moderate & 51.69 & 51.69 & & \\
\hline 93 & High & Low & 9.67 & 9.67 & & 9.67 \\
\hline 94 & High & Low & 3.87 & 3.87 & & 3.87 \\
\hline 95 & Moderate & Moderate & 19.56 & & 19.56 & \\
\hline 96 & Moderate & Moderate & 5.80 & & 5.80 & \\
\hline \multirow[t]{2}{*}{97} & High & Moderate & 9.78 & 9.78 & & \\
\hline & High & Moderate & 578.00 & 578.00 & & 578.00 \\
\hline 98 & High & Moderate & 2.58 & 2.58 & & \\
\hline 99 & High & Moderate & 5.87 & 5.87 & & \\
\hline 100 & High & Low & 9.67 & 9.67 & & 9.67 \\
\hline \multirow[t]{2}{*}{101} & High & Moderate & 3.91 & 3.91 & & \\
\hline & High & Low & 12.00 & 12.00 & & 12.00 \\
\hline \multirow[t]{2}{*}{102} & High & Low & 1.93 & 1.93 & & 1.93 \\
\hline & High & Moderate & 7.83 & 7.83 & & \\
\hline \multirow[t]{2}{*}{103} & High & Low & 5.80 & 5.80 & & 5.80 \\
\hline & High & Moderate & 10.66 & 10.66 & & \\
\hline \multirow[t]{2}{*}{104} & High & Moderate & 5.33 & 5.33 & & \\
\hline & High & Low & 24.00 & 24.00 & & 24.00 \\
\hline
\end{tabular}




\begin{tabular}{|c|c|c|c|c|c|c|}
\hline 105 & High & Low & 1.16 & 1.16 & & 1.16 \\
\hline 106 & High & Low & 9.67 & 9.67 & & 9.67 \\
\hline 107 & High & Moderate & 19.56 & 19.56 & & \\
\hline \multirow[t]{2}{*}{108} & High & Low & 9.67 & 9.67 & & 9.67 \\
\hline & High & Moderate & 26.64 & 26.64 & & \\
\hline 109 & High & Moderate & 77.53 & 77.53 & & \\
\hline 110 & High & Low & 30.36 & 30.36 & & 30.36 \\
\hline 111 & High & Low & 9.67 & 9.67 & & 9.67 \\
\hline 112 & High & Moderate & 15.99 & 15.99 & & \\
\hline \multirow[t]{2}{*}{113} & Moderate & Moderate & 91.93 & & 91.93 & \\
\hline & Moderate & Moderate & 248.90 & & 248.90 & \\
\hline 114 & High & Low & 8.78 & 8.78 & & 8.78 \\
\hline 115 & High & Low & 5.80 & 5.80 & & 5.80 \\
\hline \multirow[t]{2}{*}{116} & High & Moderate & 15.99 & 15.99 & & \\
\hline & High & Low & 664.00 & 664.00 & & 664.00 \\
\hline 117 & Moderate & Moderate & 0.97 & & 0.97 & \\
\hline 118 & Moderate & Moderate & 7.83 & & 7.83 & \\
\hline \multirow[t]{3}{*}{119} & Moderate & Moderate & 9.67 & & 9.67 & \\
\hline & Moderate & Moderate & 45.97 & & 45.97 & \\
\hline & Moderate & Moderate & 28.00 & & 28.00 & \\
\hline \multirow[t]{2}{*}{120} & High & Low & 12.65 & 12.65 & & 12.65 \\
\hline & High & Moderate & 53.29 & 53.29 & & \\
\hline \multirow[t]{2}{*}{121} & Moderate & Moderate & 3.80 & & 3.80 & \\
\hline & Moderate & Moderate & 5.80 & & 5.80 & \\
\hline \multirow[t]{2}{*}{122} & High & Low & 0.77 & 0.77 & & 0.77 \\
\hline & Death & & 514.14 & & & \\
\hline 122 & & & 13415.06 & 9921.13 & 2979.80 & 7794.75 \\
\hline
\end{tabular}

Source: Own calculation 


\section{CURRICULUM VITAE}

1 Personal information:

Full name:

DO VAN NHA

Sex:

Male

Marital status:

Married

Nationality:

Vietnamese

Date of birth:

20 May, 1973

Tel:

(84-4) 8767764

Email : $\quad$ dovannha@yahoo.com; dvannha@gwdg.de

\section{Education background}

\begin{tabular}{|c|c|c|c|c|}
\hline $\begin{array}{l}\text { Education } \\
\text { institution }\end{array}$ & Location & $\begin{array}{c}\text { Major field of } \\
\text { study }\end{array}$ & Diploma/Degree & $\begin{array}{c}\text { Years } \\
\text { attended }\end{array}$ \\
\hline $\begin{array}{l}\text { Goettingen } \\
\text { University }\end{array}$ & $\begin{array}{c}\text { Goettingen, } \\
\text { Germany }\end{array}$ & $\begin{array}{c}\text { Natural Resources } \\
\text { management }\end{array}$ & $\mathrm{PhD}$ & 2009-2012 \\
\hline $\begin{array}{l}\text { Hanoi University } \\
\text { of Agriculture }\end{array}$ & $\begin{array}{c}\text { Hanoi, } \\
\text { Vietnam }\end{array}$ & $\begin{array}{c}\text { Land use } \\
\text { management }\end{array}$ & MSc & 1999 to 2001 \\
\hline $\begin{array}{l}\text { Hanoi University } \\
\text { of Agriculture }\end{array}$ & $\begin{array}{c}\text { Hanoi, } \\
\text { Vietnam }\end{array}$ & $\begin{array}{c}\text { Land use } \\
\text { management }\end{array}$ & $\mathrm{BSc}$ & 1991 to 1996 \\
\hline
\end{tabular}

\section{Attended training courses}

\begin{tabular}{clll}
\hline Period & \multicolumn{1}{c}{ Project title } & \multicolumn{1}{c}{ Donor/Organizer } & \multicolumn{1}{c}{ Place } \\
\hline \multirow{2}{*}{$15-$} & Training on Land Use & The Rockefeller & Yunnan, China- \\
$27 / 01 / 05$ & History in Montance & Foundation, CBIK and & Luang brabang, Laos- \\
& Mainland Southeast Asia & ICIMOD & Chiang mai, Thailand
\end{tabular}


4 Employment record

\begin{tabular}{llllll}
\hline \multicolumn{1}{c}{ Organization } & \multicolumn{2}{c}{ Period } & \multicolumn{2}{c}{ Position } & \multicolumn{2}{c}{ Nature of work } \\
\hline $\begin{array}{l}\text { Hanoi University } \\
\text { of Agriculture }\end{array}$ & now & & up to & Assistant lecturer & Teaching and researching on \\
and researcher & land-use planning \\
\hline
\end{tabular}

5 Project involved

\begin{tabular}{|c|c|c|c|}
\hline Periods & Project's name & Position & Place \\
\hline $2005-2007$ & Land-use planning & Team leader & $\begin{array}{l}\text { Baoyen District, Laocai } \\
\text { Province, Vietnam }\end{array}$ \\
\hline $2003-2004$ & $\begin{array}{l}\text { Landscape planning and } \\
\text { designing for centre of district, } \\
\text { commune and village }\end{array}$ & Team leader & $\begin{array}{l}\text { Meovac District, Hagiang } \\
\text { Province, Vietnam }\end{array}$ \\
\hline 2002 & $\begin{array}{l}\text { Land-use planning toward } \\
\text { industrialization, modernization } \\
\text { agriculture and rural area }\end{array}$ & Team leader & $\begin{array}{l}\text { Thuongtin District, Hatay } \\
\text { Province, Vietnam }\end{array}$ \\
\hline 1999-2001 & Land-use planning & $\begin{array}{l}\text { Project } \\
\text { member }\end{array}$ & $\begin{array}{l}\text { Hagiang } \\
\text { Vietnam }\end{array}$ \\
\hline 1998-1999 & Land-use planning & $\begin{array}{l}\text { Project } \\
\text { member }\end{array}$ & $\begin{array}{l}\text { Phongchau District, } \\
\text { Phutho Province, Vietnam }\end{array}$ \\
\hline 1996-1997 & Soil evaluation & $\begin{array}{l}\text { Project } \\
\text { member }\end{array}$ & $\begin{array}{l}\text { Daitu District, Thainguyen } \\
\text { Province, Vietnam }\end{array}$ \\
\hline
\end{tabular}

\section{Publication:}

1. Do Van Nha, ...... Study on designing program for communal Land Use Planning . The Vietnam Soil Science Magazine. Vol 37, 2011

2. Do Van Nha, ..... The detail planning model of communal centers in Chi Linh District, Hai Duong Province, Viet Nam. The journal of Science and Developmemt, Hanoi University of Agriculture, Vietnam. Vol 6, No2, 2008.

3. Do Van Nha, ..... Status and Effect of Agricultural Land Use after Land Consolidation for Industrialization and Modernization in Agriculture and Rural area in Haiduong Province. The Vietnam Soil Science Magazine. Vol 25, 2006. 
4. Do Van Nha, ...... Assessment of natural characters and proposal for planning schemes for proper land use in Lunglau area, Trungkhanh District, Caobang Province. The Land Administration Magazine, Ministry of Land administration and Environment. Vol 1, 2005.

5. Do Van Nha, ...... Results of land suitability classification in Caoloc District, Langson Province, Vietnam. The Journal of Agricultural Science and Technology, Hanoi University of Agriculture, Vietnam. Vol 3, 2004.

6. Do Van Nha, ....., Land evaluation in Lamthao District, Phutho Province, Vietnam. The Vietnam Soil Science Magazine. Vol 16, 2002. 